\title{
A EVOLUÇÃO DIFERENCIADA DA AGROINDÚSTRIA CANAVIEIRA NO BRASIL DE 1975 A 1995
}

\section{PERY FRANCISCO ASSIS SHIKIDA}

\section{Economista}

Orientador: Prof. Dr. Carlos José Caetano Bacha

\begin{abstract}
Tese apresentada à Escola Superior de Agricultura "Luiz de Queiroz", Universidade de São Paulo, para obtenção do título de Doutor em Ciências, Área de Concentração: Economia Aplicada.
\end{abstract}

P I R A C I C A B A

Estado de São Paulo - Brasil

Outubro - 1997 
Dados Internacionais de Catalogação na Publicação (CIP) DIVISÃo DE BIBLIOTECA E DOCUMENTAÇÃO - Campus "Luiz de Queiroz"/USP

Shikida, Pery Francisco Assis

A evolução diferenciada da agroindústria canavieira no Brasil de 1975 a 1995.

- - Piracicaba, 1997.

$191 \mathrm{p}$.

Tese (doutorado) - Escola Superior de Agricultura Luiz de Queiroz, 1997.

Bibliografia.

1. Análise fatorial 2. Brasil 3. Cana-de-açúcar 3. Indústria sucroalcooleira (1975 - 1995) I. Título 


\title{
A EVOLUÇÃO DIFERENCIADA DA AGROINDÚSTRIA CANAVIEIRA NO BRASIL DE 1975 A 1995
}

\author{
PERY FRANCISCO ASSIS SHIKIDA
}

Aprovada em: 25.11 .1997

Comissão julgadora:

Prof. Dr. Carlos José Caetano Bacha

ESALQ/USP

Prof. Dr. Joaquim José Martins Guilhoto

ESALQ/USP

Profa. Drà . Heloisa Lee Burnquist

ESALQ/USP

Prof. Dr. Mauro Borges Lemos

FACE/UFMG

Prof. Dr. Sérgio Luiz Monteiro Salles Filho

NPCT/UNICAMP

Zabacha

Prof. Dr. Carlos José Caetano Bacha

Orientador 
"VIDA É ARTE"

PL 
Dedico este trabalho ao meu pai, Shigueyuki Shikida, in memorian, na esperança de dizer "muito obrigado". 


\section{AGRADECIMENTOS}

Este trabalho contou com o inestimável apoio intelectual e moral de muitas pessoas e instituições.

Desejo exprimir o meu agradecimento, acima de tudo, a Mioyaôokami e a Oshieoyá-Samá, pela oportunidade de participar de Sua Obra Criadora.

Externo novamente o meu agradecimento ao Prof. Dr. Carlos José Caetano Bacha, a quem devo a orientação deste trabalho, realizada sempre com ética e profundo espírito científico.

Aos docentes e funcionários do Programa de Doutoramento em Economia Aplicada da ESALQ/USP, em particular, ao Prof. Dr. Joaquim José Martins Guilhoto e a Prof. Dr ${ }^{\mathrm{a}}$. Heloísa Lee Burnquist, pelas sugestões valiosas e fonte permanente de estímulo à preparação deste trabalho, a minha gratidão.

Ao Prof. Dr. Sérgio Luiz Monteiro Salles Filho (Núcleo de Política Científica e Tecnológica/UNICAMP) e ao Prof. Dr. Mauro Borges Lemos (CEDEPLAR/FACE/UFMG) - "sou levado à lembrança da minha formação básica como profissional e os meus primeiros mestres" -, pelos preciosos comentários e proficuas sugestões, o meu agradecimento.

Agradeço também às usinas e destilarias que responderam, com muita lucidez, o questionário aplicado, e ao pessoal da Hedge (SP), cujas informações sobre a agroindústria canavieira foram de grande valia.

À Universidade Estadual do Oeste do Paraná (UNIOESTE), em particular, ao Departamento de Economia - Campus de Toledo -, pela oportunidade de realizar este programa de qualificação docente; à CAPES, pelo financiamento concedido; e ao Departamento de Economia e Sociologia Rural da ESALQ/USP, em nome do Prof. Dr. José Vicente Caixeta Filho, pelos recursos concedidos para a aplicação de questionários e visitas técnicas; o meu reconhecimento e gratidão.

Aos colegas do Curso de Pós-Graduação em Economia Aplicada da ESALQ/USP, pelo apoio constante e convívio engrandecedor; à família Kitaka (PE), família Uehara (SP), Anderson, Lídia, Mônica, Salete e Renata, o meu "obrigadão", ainda que este ato não possa expressar a magnitude do seu significado.

Aos meus irmãos, pelo sentido de união, e à Sonia, minha esposa, por ensinar, "em tempo de escassez de tempo", que na vida nada se perde por amor, tudo se ganha por amar, a minha eterna gratidão. 


\section{SUMÁRIO}

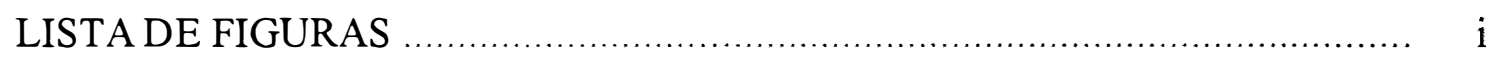

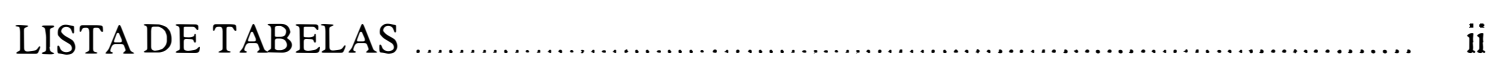

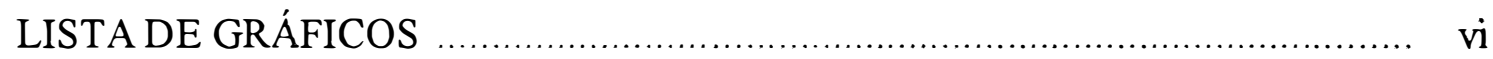

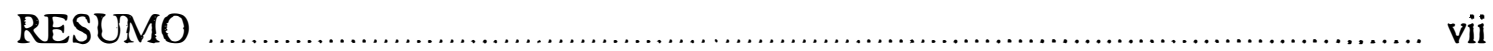

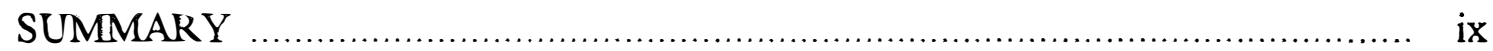

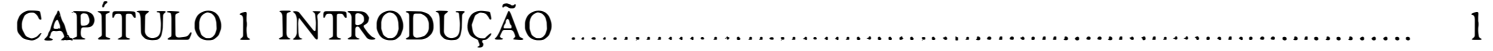

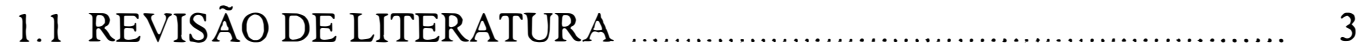

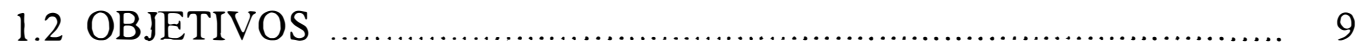

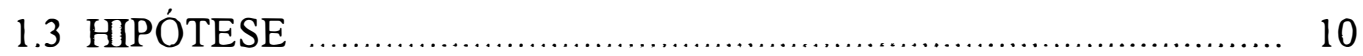

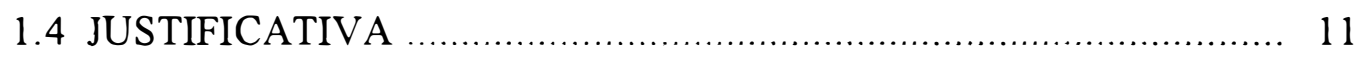

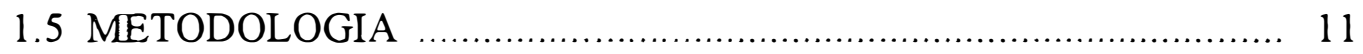

CAPÍTULO 2 REFERENCIAL TEÓRICO …......................................... 13

2.1 A Teoria de Schumpeter e dos neoschumpeterianos ....................... 16

2.1.1 Principais aprofundamentos do referencial analítico neoschumpeteriano ................................................. 23

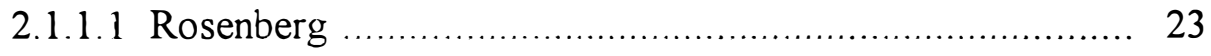

2.1.1.2 Freeman .................................................. 29

2.1.1.3 Nelson \& Winter ........................................ 31

2.1.1.4 Dosi ........................................................ 37

2.1.1.5 Cochrane ................................................... 40

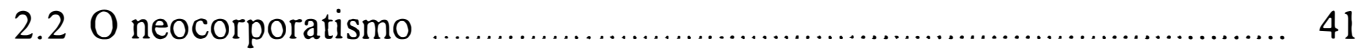

CAPÍTULO 3 A AGROINDÚSTRIA CANAVIEIRA BRASILEIRA DE SUA

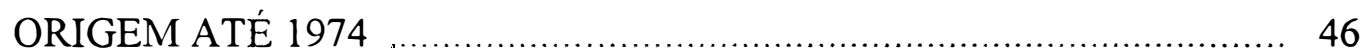

CAPÍTULO 4 ASPECTOS DA ORGANIZAÇÃO, GERAÇÃO DE TECNOLOGIA E PRINCIPAIS PRODUTOS E SUBPRODUTOS DA AGROINDÚSTRIA CANAVIEIRA DO BRASIL ....................................... 55

4.1 A organização da agroindústria canavieira ...................................... 55

4.2 Geração de tecnologia e principais produtos e subprodutos ................ 58 CAPÍTULO 5 A EVOLUÇÃO DA AGROINDÚSTRIA CANAVIEIRA BRASILEIRA DE 1975 A 1995 
5.1 A agroindústria canavieira no subperiodo 1975 a 1979: fase de expansão "moderada" do PROÁLCOOL

5.2 A agroindústria canavieira no subperíodo 1980 a 1985: fase de expansão "acelerada" do PROÁLCOOL

5.3 A agroindústria canavieira no subperíodo 1986 a 1995: fase de "desaceleração e crise" do PROÁLCOOL

5.3.1 Uma avaliação geral

5.3.2 A evolução diferenciada e o paradigma tecnológico na agroindústria canavieira

5.3.3 Situação financeira atual das empresas da agroindústria canavieira

5.3.4 Perspectivas para a agroindústria canavieira

CAPÍTULO 6 MEDIDAS DO GRAU DE MODERNIZAÇÃO DA AGROINDÚSTRIA CANAVIEIRA NO BRASIL UTILIZANDO A ANÁLISE FATORIAL

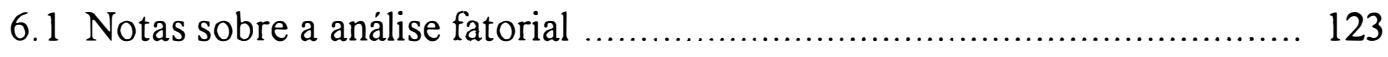

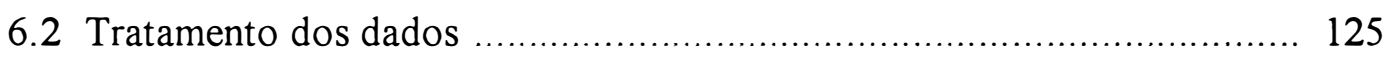

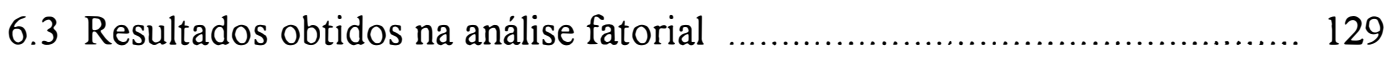

CAPÍTULO 7 AS ESTRATÉGIAS TECNOLÓGICAS DAS FIRMAS .............. 136

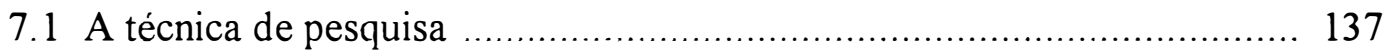

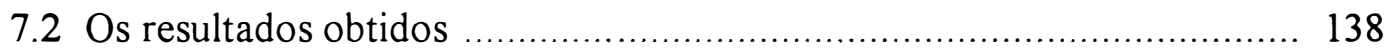

7.2.1 Avaliação das firmas sobre as políticas setoriais ...................... 141

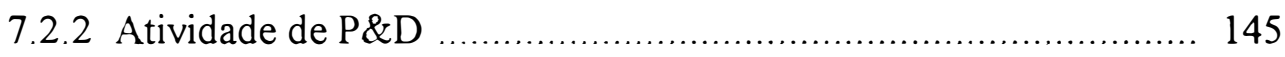

7.2.3 Mudança técnica e da produção ………………................... 148

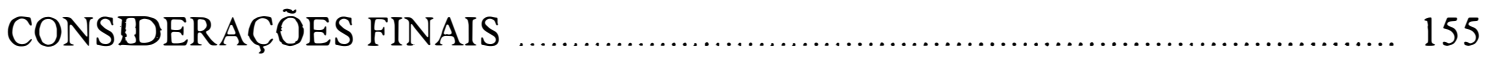

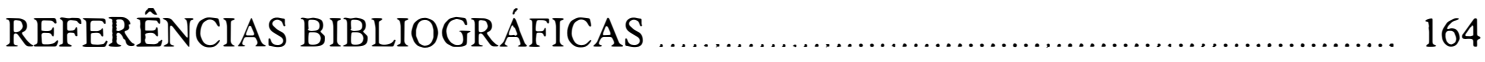

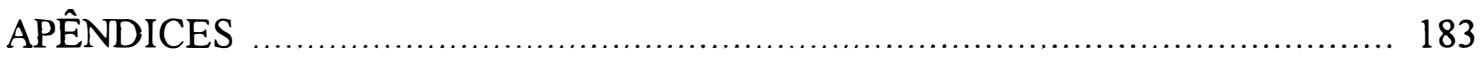

Apêndice A - Notas sobre o ciclo da lavoura canavieira e o seu calendário

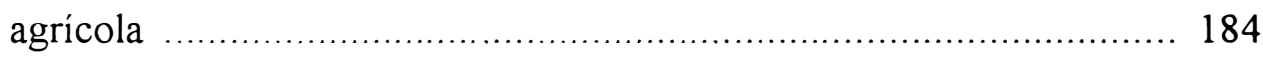

Apêndice B - Produtos calóricos e não-calóricos ………............................ 185

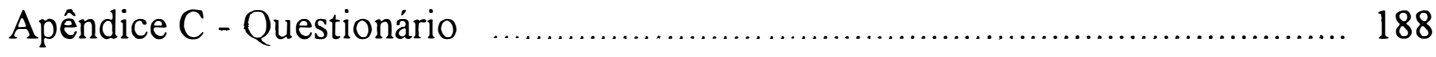




\section{LISTA DE FIGURAS}

\section{Página}

Figura 1 Esquema simplificado de um learning-by-using (LBU).

Figura 2 Esquema simplificado de um padrão de comportamento dinâmico do mercado e da firma.

Figura 3 Fluxograma do eixo agroindústria-mercado do segmento canavieiro. 
LISTA DE TABELAS

Página

Tabela 1 Valor da exportação de açúcar do Brasil, participação dessa exportação no total das exportações brasileiras e preço médio do açúcar (US\$cents/libra) - Mercado Livre, Comunidade Econômica Européia (CEE) e Estados Unidos - 1971 a 1979.

Tabela 2 Participação das aplicações do PROÁLCOOL nas aplicações totais do FUNAGRI - 1976 a 1979 (em percentagem).

Tabela 3 Distribuição espacial das usinas de açúcar (U) e destilarias de álcool (D) no Brasil, segundo macrorregião (Centro-Sul; Norte/Nordeste) e principais estados produtores - 1975 a 1979. ...

Tabela 4 Participação das aplicações do PROÁLCOOL nas aplicações totais do FUNAGRI - 1980 a 1985 (em percentagem).

Tabela 5 Evolução da capacidade de produção de álcool no Brasil, 1974/1985 (em milhões de litros/safra).

Tabela 6 Distribuição espacial das usinas de açúcar (U) e destilarias de álcool (D) no Brasil, segundo macrorregião (Centro-Sul; Norte/Nordeste) e principais estados produtores - 1980 a 1985 ...

Tabela 7 Destinação de cana moída no Brasil - 1977/78 a 1984/85 (em 1000 toneladas).

Tabela 8 Área colhida, quantidade produzida de cana-de-açúcar e rendimento agrícola no Brasil - 1974 a 1985.

Tabela 9 Produção e consumo de álcool anidro e hidratado no Brasil 1985/86 a 1995 (em milhões de litros). 
Tabela 10 Proporção de vendas de veículos a álcool sobre o total de veículos - Brasil (1980-1990 e 1994-1995).

Tabela 11 Preços pagos ao produtor de cana-de-açúcar para o estado de São Paulo (em R\$/tonelada) - preços deflacionados - valores de fevereiro de 1996.

Tabela 12 Participação relativa dos itens custos de produção para a cana-deaçúcar em SP, MG, RJ, AL e PE - em percentagens - (safras de 1982/83 a 1986/87).

Tabela 13 Margem de comercialização do açúcar standard em usinas, incluindo o valor equivalente de subprodutos; do álcool em destilarias autônomas, considerando os subprodutos; e coeficientes de transformação, Brasil. Maio de 1994.

Tabela 14 Proporção das empresas da agroindústria canavieira que apresentaram Índice de Liquidez Corrente (ILC) inferiores à unidade - 1975, 1979, 1983, 1987 e 1991.

Tabela 15 Dívidas do setor sucroalcooleiro em 1991 ( $\mathrm{Cr} \$$ milhões de setembro de 1991), valor de produção da cana-de-açúcar (Cr\$ milhões de 1991) e relação total da dívida do setor sucroalcooleiro/valor de produção da cana (em \%).

Tabela 16 Dívidas externas dos usineiros pagas pelo Governo (valores em 28/02/1991).

Tabela 17 Distribuição das empresas de açúcar (unidades) segundo escala de produção - safras de 1970/71, 1980/81 e 1991/92.

Tabela 18 Matriz de dados para a Análise Fatorial.

Tabela 19 Raízes características. 
Tabela 20 Cargas fatoriais de 4 fatores e comunalidades na análise fatorial dos 13 indicadores de modernização e caracterização da agroindústria canavieira em 14 estados do Brasil - 1975, 1980 e 1985.

Tabela 21 Valores dos quatro fatores de modernização e caracterização da agroindústria canavieira em 14 estados do Brasil - 1975, 1980 e 1985.

Tabela 22 Representatividade da amostra pesquisada em termos das produções estaduais de álcool anidro e hidratado, açúcar e empregos gerados (total da amostra pesquisada sobre os totais estaduais de cada item).

Tabela 23 Distribuição percentual das firmas pesquisadas da agroindústria canavieira quanto à situação institucional e tipo de unidade (posição no lo semestre de 1997).

Tabela 24 Fornecimento de cana-de-açúcar (valores médios) - safras 1985/86 e $1995 / 96$.

Tabela 25 Distribuição percentual das firmas pesquisadas da agroindústria canavieira quanto a evolução da produção efetiva e capacidade de produção entre as safras 1985/86 e 1995/96.

Tabela 26 Distribuição percentual das firmas pesquisadas da agroindústria canavieira quanto à extinção do Instituto do Açúcar e do Álcool e do PLANALSUCAR (posição no 1o semestre de 1997).

Tabela 27 Distribuição percentual das firmas pesquisadas da agroindústria canavieira quanto à política setorial (posição no 1 o semestre de 1997). 
Tabela 28 Firmas que declararam ser inadequadas as políticas de preços para a cana, açúcar e álcool, e de crédito; sua relação com o fato da firma ser cooperada ou não, e com a posição de favorabilidade, indiferença ou desfavorabilidade quanto à extinção do IAA (posição no lo semestre de 1997).

Tabela 29 Distribuição percentual das firmas pesquisadas da agroindústria canavieira quanto à política tecnológica - P\&D - e resolução de problemas técnicos (posição no 10 semestre de 1997).

Tabela 30 Relação entre a firma ser cooperada ou não e a realização de P\&D (valores em \%) - posição no 10 semestre de 1997.

Tabela 31 Distribuição percentual das firmas pesquisadas da agroindústria canavieira quanto à adoção de tecnologias agrícolas - safras 1985/86 e 1995/96.

Tabela 32 Distribuição percentual das firmas pesquisadas da agroindústria canavieira quanto à adoção de tecnologias mecânicas - safras 1985/86 e 1995/96.

Tabela 33 Aproveitamento de subprodutos - safras 1985/86 e 1995/96 (valores em \%). 


\section{LISTA DE GRÁFICOS}

Página

Gráfico 1 Produção de álcool por tipo de destilaria - Brasil - 1975/76 a 1978/79.

Gráfico 2 Produção de álcool anidro e hidratado, e consumo de álcool no Brasil - 1975/76 a 1978/79.

Gráfico 3 Produção de álcool por tipo de destilaria - Brasil - 1979/80 a $1984 / 85$.

Gráfico 4 Produção e consumo de álcool anidro e hidratado no Brasil $1979 / 80$ a $1984 / 85$

Gráfico 5 Destinação de cana moída no Brasil - 1977/78 a 1984/85.

Gráfico 6 Preços médios do açúcar bruto (Bolsa de Nova York, em centavos de US\$/libra-peso) e da gasolina (FOB, Roterdã, US\$/bb) - 1976-1994.

Gráfico 7 Preço da cana-de-açúcar pago aos produtores no Centro-Sul e Norte/Nordeste - 1978/1995.

Gráfico 8 Preço do açúcar pago aos produtores no Centro-Sul e Norte/Nordeste - 1978/1995.

Gráfico 9 Preço do álcool pago aos produtores no Centro-Sul e Norte/Nordeste - 1978/1995. 


\title{
A EVOLUÇÃO DIFERENCIADA DA AGROINDÚSTRIA CANAVIEIRA NO BRASIL DE 1975 A 1995
}

\author{
Autor: Pery Francisco Assis Shikida \\ Orientador: Prof. Dr. Carlos José Caetano Bacha
}

\section{RESUMO}

O objetivo geral deste trabalho é determinar e analisar os principais condicionantes da evolução diferenciada, entre estados e entre firmas, ocorrida na agroindústria canavieira do Brasil de 1975 a 1995. Como objetivos específicos, procurase obter algumas medidas do grau de modernização da agroindústria canavieira nos estados brasileiros mediante utilização da técnica de análise fatorial; e, realizar uma análise das estratégias tecnológicas adotadas pelas firmas dessa agroindústria.

$\mathrm{Na}$ execução deste trabalho foram utilizadas as idéias neoschumpeterianas e neocorporatistas. Através da utilização da técnica de análise fatorial, pôde-se captar melhor de que forma deu-se a evolução diferenciada da agroindústria canavieira entre os estados brasileiros. Para obtenção de dados sobre as estratégias tecnológicas das firmas houve aplicação de questionários.

Pode-se aferir que a crise do petróleo gerou um "gargalo" no processo produtivo, propiciando um ambiente favorável ao surgimento de alternativas energéticas. A crise da agroindústria canavieira favoreceu a "orquestração" de interesses que levou o País a optar pelo PROÁLCOOL. Com o início do PROÁLCOOL (1975) o produtor esteve novamente sujeito a uma série de arranjos institucionais patrocinados pelo Estado, que lhe garantia um paradigma subvencionista como modelo de sobrevivência. Este contexto foi bom para propiciar um maior desenvolvimento setorial; no entanto, contribuiu para a relativa falta de importância da tecnologia e do progresso técnico no interior da agroindústria canavieira. O subperíodo 1980-1985 evidenciou o aprofundamento do "gargalo", provocado pela segunda crise do petróleo, propiciando um ambiente favorável 
para o lançamento do álcool hidratado, enquanto a "orquestração" de interesses procurou corroborar essa alternativa como a opção energética mais adequada para a substituição de derivados do petróleo. Verificou-se o fortalecimento da posição hegemônica de alguns empresários considerados inovadores na agroindústria canavieira e maior adesão de empresários imitadores. De 1986 a 1995, passou-se de um período de desaceleração do crescimento à crise do PROÁLCOOL. O "gargalo", oriundo da crise do petróleo, desapareceu. Destarte, desapareceu a justificativa diante da população brasileira para manter o corporatismo em torno do PROÁlCOOL. A crise desse Programa contribuiu para avultar a diferenciação em termos produtivos existente na agroindústria canavieira, onde algumas empresas menos preparadas em termos de capacitação tecnológica encerraram suas atividades ou foram incorporadas pelas mais dinâmicas (que adotaram o paradigma tecnológico).

Os resultados derivados da análise fatorial sugeriram a modernização como estreitamente ligada ao produto álcool. O PROÁLCOOL contribuiu não só para destacar perfomances como a de São Paulo no cenário nacional, como para melhorar o perfil geral da agroindústria canavieira do Brasil. Novas regiões canavieiras, como Mato Grosso do Sul e Paraná, alcançaram um relativo destaque neste setor.

No estudo das estratégias tecnológicas adotadas pelas firmas ficou caracterizado que, não só no Norte-Nordeste, mas também no Centro-Sul, coexistem produtores modernos com os atrasados. Constatou-se um relativo avanço tecnológico para várias unidades produtivas de estados cuja concentração técnica e econômica (em torno de suas agroindústrias canavieiras) é menor vis-à-vis a São Paulo. Isto demonstra a assimilação do paradigma tecnológico como modelo de sobrevivência na agroindústria canavieira, em um contexto de pouco subsídio concedido pelo Estado. 


\title{
THE DIFFERENTIATED EVOLUTION OF SUGAR CANE INDUSTRY IN BRAZIL FROM 1975 TO 1995
}

\author{
Author: Pery Francisco Assis Shikida \\ Adviser: Prof. Dr. Carlos José Caetano Bacha
}

\section{SUMMARY}

The general objective of this work is to determine and to analyze the main reasons for differentiated evolution among states and among firms, occurred in the Brazilian sugar cane industry from 1975 to 1995. Specific objectives are: a) to obtain some measures of the modernization degree for the sugar cane industry throughout Brazilian states, using factor analysis; and, b) performing an analysis on firm technological strategies.

Neoschumpeterian and neocorporatist ideas were used as a theoretical background. The factor analysis has shown to be a good tool in analyzing the way differentiated evolution took place among the Brazilian states. Data on firm technological strategies were obtained through a survey, with application of questionnaire.

A bottle neck in the productive process originated by the oil crisis gave rise to an environment favoring energy alternatives. The sugar cane industry crisis generated an "interests arrangement" that lead the country to opt for PROALCOHOL Programme. With the beginning of PROALCOHOL, producers were subject to a series of government institutional arrangements that warranted a subventionist paradigm as a survival model. In this context there was a growth of production in the sector with very little importance given to technological progress. The bottle neck worsen from 1980 to 1985 due to the second oil crisis, generating a favorable environment for producing hydrated alcohol. Simultaneously, the "interests arrangement" supported the hydrated alcohol as the most adequate energy option for the substitution of oil derivatives. The strengthening of some innovative entrepreneurs hegemony position was verified as well as a higher followers 
adhesion. From 1986 to 1995, PROALCOHOL went from a slower growth to a crisis. The bottle neck generated by the oil crisis disappeared, and so did also disappeared the justification to maintain corporativism around the program. The crisis of the program contributed to increase the differentiation in productivity terms existing in the sugar cane industry. As a result, the less technological prepared firms went out of business or were incorporated by the most dynamic ones, the ones that adopted the technological paradigm.

The results from the factor analysis suggested that modernization was closely linked to alcohol production. The PROALCOHOL contributed not only to stress the performance of the state of São Paulo at national level, but also to improved the general profile of the Brazilian sugar cane industry. New sugar cane regions such as the state of Mato Grosso do Sul and Paraná reached a relevant position in the sector.

It was also found that modern producers do exist with traditional producers in North-Northeast and Center-South regions. Many production units from states where technical and economic concentration was lower than the state of São Paulo, showed some technical progress. That fact demonstrates the assimilation of the technical paradigm as a survival model in the sugar cane industry. 


\section{INTRODUÇÃO}

Este trabalho intenciona determinar e analisar os principais condicionantes da evolução diferenciada, entre estados e entre firmas, ocorrida na agroindústria canavieira do Brasil de 1975 a 1995.

Inicialmente, faz-se necessário definir e distinguir os termos agroindústria canavieira e complexo agroindustrial canavieiro. Este último engloba o conjunto de atividades produtivas e comerciais que envolvem os produtores de insumos; a produção de cana-de-açúcar propriamente dita, sendo esta feita por fornecedores e/ou proprietários de usinas e destilarias; e a transformação industrial, geradora de produtos (açúcar e álcool) e subprodutos (bagaço, vinhoto, etc) que, conforme sua especificação, destinamse ao mercado interno e/ou externo. O subconjunto composto pelo segmento agrícola e o segmento industrial processador da cana-de-açúcar é conhecido na literatura como agroindústria canavieira.

A agroindústria canavieira do Brasil tem uma peculiaridade própria, qual seja, amiúde fôra objeto de regulamentações do Estado. Vale citar, por exemplo, que a partir da criação do Instituto do Açúcar e do Álcool (IAA), na década de 30, o produtor da agroindústria canavieira passou a estar sujeito a uma série de arranjos institucionais que ligavam os interesses organizados do setor às estruturas de decisão do Estado. Segundo Olalde (1993), mesmo após a extinção do IAA, através da Medida Provisória no 151 (15/03/1990), continuam a vigorar práticas como a fixação de quotas e planejamento de safras - desta vez a cargo da Secretaria de Desenvolvimento Regional (SDR), no âmbito do Departamento de Assuntos Sucroalcooleiros. A privatização das exportações foi a principal mudança verificada nesse novo panorama de desregulamentação gradual na agroindústria canavieira. Atualmente, cabe ao Ministério da Indústria, do Comércio e do Turismo (MICT), boa parte da regulamentação estatal feita na economia canavieira (MINISTÉRIO cria certificado para impedir fraudes de usineiros, 1997). 
Com efeito, com expedientes como a garantia de margens de lucro, reserva de mercado, concessão de subsídios, entre outros, a intervenção do Estado contribuiu para desfavorecer o surgimento de um ambiente concorrencial na agroindústria canavieira. Isto, em parte, explica a relativa falta de importância do progresso técnico na determinação das estruturas de mercado da agroindústria canavieira. Não obstante, as crises financeira e fiscal do Estado nas décadas de 80 e 90 , pari passu às variações dos mercados do açúcar e do álcool, revelaram a existência de produtores (especialmente de São Paulo) que optaram pelo maior desenvolvimento tecnológico de suas estruturas produtivas, seja no âmbito agrícola, seja no âmbito industrial, demarcando uma outra dinâmica nesse processo de evolução diferenciada da agroindústria canavieira no Brasil.

Além dessa introdução, a parte inicial deste trabalho consta de uma breve revisão de literatura e explicitação dos objetivos, hipótese, justificativa e metodologia. Isto posto, este trabalho subdivide-se ainda em seis capítulos. $O$ segundo capítulo apresenta o referencial teórico apropriado para interpretar os principais condicionantes da evolução diferenciada ocorrida na agroindústria canavieira do Brasil, sob a ótica do desenvolvimento tecnológico e do papel do Estado nesta atividade. O terceiro e o quarto capítulos permitem uma breve visão histórica fundamental para o entendimento de certos aspectos da atual conjuntura da agroindústria canavieira, além de oferecer um exame sintético do panorama estrutural do que existe no eixo agroindústria-mercado (destacando-se a organização, geração de tecnologia, principais produtos e subprodutos). À luz do referencial teórico adotado neste trabalho é analisada, no quinto capítulo, a evolução da agroindústria canavieira brasileira de 1975 a 1995, ressaltando-se nesse período as fases que caracterizaram tal agroindústria: 1975 a 1979, fase de expansão "moderada" do PROÁLCOOL; 1980 a 1985, fase de expansão "acelerada" do PROÁLCOOL; e, 1986 a 1995, fase de "desaceleração e crise" do PROÁLCOOL. No sexto capítulo, por meio da utilização da técnica de análise fatorial, procura-se obter algumas medidas do grau de modernização da agroindústria canavieira e da desigualdade existente entre os estados brasileiros. Um estudo mais detalhado em termos de algumas firmas desse setor é feito no sétimo capítulo, com a análise de resultados de dados primários obtidos via aplicação de questionários. Por último, nas considerações finais são sumariadas as principais implicações deste estudo. 


\subsection{REVISÃO DE LITERATURA}

Nesta breve revisão bibliográfica serão ressaltados três temas de importância para a caracterização do objetivo ora proposto: uma abordagem da historicidade (nacional e regional) da agroindústria canavieira; a relação Estado-agroindústria canavieira; e, aspectos da evolução diferenciada desta agroindústria. Esses últimos motivam a realização do presente trabalho.

Segundo Pina (1972, p.11), "a história do Brasil se encontra tão intimamente ligada ao cultivo da cana-de-açúcar, que se faz impossivel uma dissociação, sob a pena de incorrer-se em uma falsidade." De fato, com uma tradição de mais de quatro séculos, a cultura canavieira brasileira tem sido tema de várias abordagens acadêmicas. Dentre essas cabe citar aquelas que, a partir de diferentes modos, ressaltaram a importante participação da cana-de-açúcar na formação econômica do País, quais sejam: Calmon (1935), Amaral (1940), Sobrinho (1941), Dé Carli (1942), Azevedo (1958), Simonsen (1969), Jambeiro (1973), Paiva et al. (1973), Furtado (1974), Singer (1977), Gnaccarini (1980), Prado Júnior (1981) e Ramos (1991).

Outrossim, pode-se notar, além do conteúdo histórico examinado em termos nacionais, alguns estudos que se preocuparam com a análise da evolução da agroindústria canavieira especificamente para estados do Brasil. Dentre estes, enfatizam-se: Meyer (1935), Dé Carli (1943), Petrone (1968), Queda (1972), Gnaccarini (1972), Ferreira (1981), Ramos (1983), Manoel (1985), Camargo (1988), Bray (1989) e Moreira, E. (1989), para São Paulo; Silva (1935), Eisenberg (1977), Wanderley (1979), Farias (1995) e Lima \& Silva (1995), para Pernambuco; Lima (1976) e Wanderley (1981), para Alagoas; Clarck (1935), Costa Filho (1963), Banco de Desenvolvimento de Minas Gerais - BDMG (1964, 1969, 1973 e 1985), Renault (1978), Rodrigues (1979), Mota (1987), Shikida \& Bacha (1994) e Shikida \& Guilhoto (1996), para Minas Gerais; Garcia (1984) e Garcia \& Adams (1988), para o Ceará; Gomes Neto (1979), para o Espírito Santo: Lopes (1985) e Guerra (1995), para o Paraná; e Neves (1981), para o Rio de Janeiro.

Afora este caráter histórico, uma maior explicitação e sistematização das referências bibliográficas levantadas mostra, segundo Szmrecsányi (1979), que da canade-açúcar originam-se não só um dos alimentos básicos para o ser humano - o açúcar como também uma série de derivados de usos alternativos, como o álcool, o melaço, a 
aguardente, o bagaço da cana, etc. Neste sentido, para esse autor, a importância econômica da cana-de-açúcar está diretamente ligada aos diversos produtos e subprodutos advindos da industrialização dessa planta e à sua multiplicidade de funções (por exemplo, o bagaço da cana pode ser utilizado na co-geração de energia elétrica, como componente para a ração animal, como adubo e/ou para a produção de celulose).

A importância econômica da cana-de-açúcar, por outro lado, contribuiu para suscitar várias intervenções governamentais na agroindústria canavieira brasileira, seja para regular as relações entre usineiros e fornecedores de cana (Sobrinho, 1941), seja para administrar um Programa da amplitude do Programa Nacional do Álcool - PNA ou PROÁLCOOL (Magalhães et al., 1991). Na opinião de Goldin \& Rezende (1993, p.31), "dos produtos agrícolas brasileiros, o açúcar é o mais controlado".

Existe uma literatura que tem empenhado consideráveis esforços no estudo da relação Estado-agroindústria canavieira. São exemplos claros desse tipo de abordagem, questões como: a ideologia, o Estado e a ação empresarial nessa agroindústria (Gnaccarini, 1972); a agroindústria açucareira e sua legislação (Pina, 1972); os principais condicionantes do planejamento da agroindústria canavieira (Szmrecsányi, 1979); o Estado e a agroindústria canavieira do Nordeste (Lima, 1988a e 1988b; Lima \& Melo, 1989); ou mesmo o mercado de trabalho desse setor e sua regulamentação (Ricci et al., 1994).

Esta temática da intervenção estatal na agroindústria canavieira, já discutida por Queda (1972) e Ramos \& Belik (1989), continua sendo objeto de estudo, indo desde a análise das intervenções do governo que visem a adoção de medidas em face das oscilações do mercado externo açucareiro (Banco Central do Brasil - BACEN, 1986 e 1992), até a atuação do governo no que se refere à condução do PROÁLCOOL (Magalhães et al., 1991).

As primeiras experiências sobre a utilização do álcool combustível para veículos automotores no Brasil remontam à segunda década do século XX [Sociedade dos Produtores de Álcool - SOPRAL (1984)]. Todavia, o desenvolvimento tecnológico do álcool para fins carburantes, bem como de motores movidos exclusivamente a álcool, somente veio lograr relativo êxito com o PROÁLCOOL, já no último quartel do século XX. O PROÁLCOOL, implementado a partir de 1975, contribuiu para a ocorrência de 
uma série de modificações na estrutura fisica, econômica e política da agroindústria canavieira brasileira, trazendo no seu bojo várias inovações - "novo" produto (álcool combustivel); modernas técnicas de produção; "novo" mercado criado (para fins carburantes) e novas composições agroindustriais instituídas (destilarias anexas e autônomas); além do "novo" motor. Como resultado desse Programa, a produção de álcool cresceu $1.831 \%$ entre 1975 e 1985 [Cooperativa dos Produtores de Cana, Açúcar e Álcool do Estado de São Paulo Ltda - COPERSUCAR (1989a)], sendo que a produção de veículos automotores movidos exclusivamente a álcool subiu de 33.898 unidades em 1979 para 646.200 unidades em 1985, um crescimento da ordem de 1.806\% [Companhia Energética de Minas Gerais - CEMIG et al. (1987b)].

De modo geral, pode-se dizer que o PROÁLCOOL contribuiu para a modernização do parque agroindustrial da cana-de-açúcar e para consolidar a hegemonia de São Paulo nesse cenário (Shikida, 1996). Existe toda uma literatura versando sobre questões pertinentes ao PROÁLCOOL. Dentre os trabalhos elaborados a respeito, cabe citar: Melo \& Fonseca (1981), Pelin (1983), Gontijo (1985), Motta (1987), Reyes (1989), Magalhães et al. (1991), Brugnaro (1992), Fischer (1992), Shikida (1994 e 1996), Fernandes \& Coelho (1996) e Shikida \& Lopez (1997).

Além do PROÁLCOOL, a atividade açucareira ainda continua importante para o Brasil. Fazendo um cotejo da produção, consumo e exportação de açúcar do Brasil no cenário mundial entre 1974 e 1994, a partir de dados de Abbott (1990) e BACEN (1992, 1993, 1994 e 1996), observa-se que este País produziu, em média, 8,7\% do total produzido em termos mundiais e consumiu, em média, $6,5 \%$ do total mundial. As exportações brasileiras de açúcar representaram, em média, 8,0\% do total exportado mundialmente. Torna-se oportuno salientar que o Brasil consumiu, em média, aproximadamente $73,8 \%$ do açúcar produzido internamente, enquanto as exportações corresponderam ao restante do total produzido. Essas exportações de açúcar significaram, em média, $4,7 \%$ da receita total das exportações brasileiras durante o período de 1965 a $1994 .{ }^{1}$ Embora seja menor a parcela de produção nacional destinada ao mercado externo, as exportações brasileiras de açúcar têm figurado entre as cinco

\footnotetext{
${ }^{1}$ Segundo dados da Companhia Energética de Minas Gerais - CEMIG et al. (1987a), Fundação Instituto Brasileiro de Geografia e Estatística - FIBGE (1990), Food and Agriculture Organization of the United Nations - FAO (1992), BACEN (1989 e 1991) e Associação Promotora de Estudos da Economia - APEC (1995).
} 
primeiras em termos mundiais. De acordo com Burnquist (1996, p.8), "no mercado externo, o Brasil tem-se destacado pela rápida expansão de sua participação, passando a ocupar a posição de maior produtor e exportador de açúcar na safra 1995/96."

Não obstante a progressiva fragmentação do setor açucareiro mundial - haja vista suas recentes crises de superprodução e fenômenos como a concorrência e a complementariedade impostas pelos sucedâneos do açúcar - e da controvérsia quanto à manutenção do PROÁLCOOL face aos baixos preços do petróleo, as referências apontadas neste estudo revelam a importância da agroindústria canavieira brasileira. Outros indicadores corroboram tal colocação: como a área colhida com cana-de-açúcar ter significado cerca de $8,4 \%$, em média, de toda a área colhida no Brasil durante o quadriênio 1990-93, sendo superada apenas pelo milho, soja, feijão e arroz (ANUÁRIO ESTATÍSTICO DO BRASIL, 1993 e 1994). Ou, pelo fato da atividade sucroalcooleira ser responsável por aproximadamente $2 \%$ do PIB nacional, arrecadando US\$ 1,2 bilhão de impostos e gerando algo como 1 milhão de empregos diretos (Olalde, 1993).

Contudo, do relativo realce da agroindústria canavieira brasileira emerge uma questão assaz curiosa: se quem dirigiu o desenvolvimento deste setor produtivo foi o Estado, através de mecanismos regulamentadores, como se comportou a concorrência interfirma, no seu aspecto tecnológico, diante desse quadro?

Para Goldin \& Rezende (1993), os mecanismos de intervenção estatal propostos pelo Instituto do Açúcar e do Álcool para a agroindústria canavieira solaparam a eficiência da produção brasileira, pois, ao incentivar essa atividade em áreas onde eram inexistentes as vantagens comparativas (para tal finalidade), os consumidores de açúcar e álcool e os produtores - ditos eficientes - tiveram que pagar o ônus dessa ineficiência.

Em Belik (1985), cujo trabalho investigou o funcionamento do aparato de pesquisa agronômica voltado para a cana-de-açúcar em São Paulo, observou-se que a tecnologia pôde desempenhar um papel fundamental para a competitividade setorial, sobretudo em uma agroindústria rigorosamente controlada pelo Estado.

Em trabalho posterior, Belik (1992) salienta que o Estado teve um papel fundamental na estruturação e modernização da agroindústria canavieira. Para tanto, este autor utilizou-se do enfoque neocorporatista, que lhe permitiu entender como o Estado 
operacionalizou suas políticas públicas, interagindo com grupos privados, de forma a procurar atender os diversos interesses que gravitaram em torno desta agroindústria.

No caso específico da agroindústria canavieira nordestina, muito embora a cultura da cana esteja há séculos ocupando o espaço econômico da região, desta sobressai o atraso tecnológico e a conseqüente baixa produtividade do setor - Lima \& Melo (1989). Para esses autores, a manutenção da agroindústria canavieira no Nordeste deve-se, sobretudo, à capacidade que os usineiros e cultivadores têm de assegurar junto ao Estado expedientes como subsídios, reserva de mercado, etc.

Shikida (1992) e Shikida \& Bacha (1994), referindo-se a Minas Gerais, concluíram que a agroindústria canavieira desse estado defasou-se em relação ao congênere de maior expressão nacional - São Paulo -, devido às características naturais e econômicas pertencentes a essa última unidade federativa, o que permitiu às unidades produtivas paulistas serem mais capitalizadas e avançadas no aspecto tecnológico. Ademais, o Estado, traduzido nas políticas do IAA, contribuiu para o predomínio da usina sobre o engenho, não dando o adequado apoio à modernização da agroindústria canavieira de Minas Gerais, estruturada, fundamentalmente, em unidades produtivas mais arcaicas.

Reportando ao BDMG (1973), verifica-se, também, a questão do baixo padrão tecnológico como um dos empecilhos para que a agroindústria canavieira mineira fizesse as atualizações necessárias no seu sistema produtivo, de forma a atender plenamente a demanda doméstica.

As questões regionais que foram retratadas anteriormente não se adequam - no âmbito geral - ao caso paulista, posto ser São Paulo o destaque ímpar da agroindústria canavieira brasileira. Para Szmrecsányi (1979), a agroindústria canavieira de São Paulo aparece como a mais dinâmica entre as existentes do País, tendo superado, já no final da década dos quarenta deste século, o eixo da agroindústria canavieira do Nordeste. Os fatores locacionais (tais como a maior proximidade dos grandes centros consumidores nacionais), condições edafo-climáticas favoráveis e uma maior concentração econômica em torno da agroindústria canavieira paulista, além de uma razoável tecnologia de produção, configuram-se como os principais determinantes para esta hegemonia. Segundo Ricci et al. (1994, p.101): 
"(...) o padrão tecnológico do setor sucroalcooleiro é definido em São Paulo e a partir dai é repassado para os demais estados produtores.

O ritmo de incorporação do progresso técnico é mais elevado em São Paulo porque é neste estado que o setor conseguiu tornar-se um Complexo Agroindustrial Completo, com a instalação de um Departamento Produtor de Bens de Capital para o próprio setor sucroalcooleiro (DI agricola) em São Paulo. E neste estado que estão localizadas as maiores empresas produtoras de tecnologia para o setor. Estão também localizados em São Paulo os dois maiores centros de pesquisa: o Centro Tecnológico da Cana, da COPERSUCAR e o (...) Centro de Ciências Agrárias da Universidade Federal de São Carlos."

Mesmo diante de um quadro de restrições à expansão dos mercados de açúcar (devido ao excesso de oferta no mercado internacional, salvo períodos de "bolhas de euforia", e diante dos fenômenos de concorrência e complementariedade porque vem passando o açúcar nos anos 80 e primeira metade dos anos 90) e álcool (diante da crise do PROÁLCOOL), algumas empresas paulistas têm investido na modernização da produção desses produtos, bem como em outras possibilidades de aproveitamento da cana-de-açúcar como matéria-prima (bagaço da cana para fins energéticos ou como ração animal, produção de alcoolquímicos, etc). De certo modo, tal fato contribui para qualificar estas empresas como candidatas a sobreviver e se expandir nessa nova realidade setorial (Moreira, E. 1989). A Usina da Barra é um exemplo disto: "para garantir os niveis de qualidade e produtividade, a empresa dispõe de setores de pesquisa altamente especializados, que vão de um Laboratório Entomológico (...) a um Laboratório de Genética e Melhoramentos (...)" (Castro, 1995, p.22).

Para Eid (1996), os elementos explicativos do progresso técnico na agroindústria sucroalcooleira paulista são basicamente: a mudança no método do pagamento da canade-açúcar (pelo teor de sacarose); a necessidade das usinas em qualificar um coletivo de trabalho disponível o ano inteiro; a tendência gradual de afastamento do Estado intervencionista e de reconcentração do oligopólio no setor; a tendência de obsolescência da instrumentação industrial pneumática nas indústrias de processo contínuo em substituição gradual pela instrumentação eletrônica digital; a organização e luta do movimento sindical agrícola, o que intensificou a mecanização agrícola; as novas 
tecnologias integradas às novas formas de gestão empresarial; e, as pressões da sociedade civil para a proteção ambiental e melhoria na qualidade dos produtos.

Isto posto, observa-se que a literatura revisada mostrou que São Paulo - de modo geral, pois os desníveis tecnológicos ocorrem também dentro do âmbito estadual - teve, em determinado momento, uma gama de condições favoráveis para o desenvolvimento da agroindústria canavieira; enquanto o Nordeste e Minas Gerais, destacados nesta revisão, caracterizaram-se pelo atraso tecnológico.

Houve, nitidamente, uma evolução diferenciada entre os estados brasileiros no que respeita à agroindústria canavieira. Naturalmente, não deve ser deduzido que essas transformações deveriam processar em ritmos uniformes e de formas homogêneas. Isto é perfeitamente compreensível se se considerar a própria heterogeneidade da evolução secular da agroindústria canavieira nacional - vide, por exemplo, Pina (1972); ou mesmo diante do relativo reordenamento geográfico da lavoura canavieira ocorrido durante o PROÁLCOOL (Ricci et al., 1994).

Contudo, ainda existem pontos específicos sobre a agroindústria canavieira não esclarecidos. Como o Estado interviu no padrão de busca (ou seja, atividades organizacionais que estão associadas com a avaliação das rotinas correntes das firmas) das usinas, destilarias e outras unidades produtivas ligadas a essa agroindústria, criando e/ou modificando as possibilidades de implementação de uma inovação? $\mathrm{O}$ PROÁLCOOL teve de fato uma contribuição relativa para a questão da modernização do parque agroindustrial da cana-de-açúcar? Quais foram as estratégias tecnológicas adotadas pelas usinas e destilarias que se distanciaram das demais? Como os problemas técnicos do processo produtivo foram resolvidos?

A busca de respostas para essas questões motiva a realização deste estudo.

\subsection{OBJETIVOS}

O objetivo geral deste trabalho é determinar $e$ analisar os principais condicionantes da evolução diferenciada, entre estados e entre firmas, ocorrida na agroindústria canavieira do Brasil de 1975 a 1995. Como objetivos especificos, procura-se obter algumas medidas do grau de modernização da agroindústria 
canavieira nos estados brasileiros, mediante utilização da técnica de análise fatorial; e, realizar uma análise das estratégias tecnológicas adotadas pelas firmas dessa agroindústria.

Salienta-se que o período a ser estudado (1975 a 1995) intenciona englobar as três fases do Programa Nacional do Álcool, 1975-1979 (expansão "moderada"), 19801985 (expansão "acelerada") e 1986-1995 ("desaceleração e crise"). Não obstante, é preciso frisar que o ano de 1995 serve, aqui, apenas como referencial-limite para o estudo (no qual foi possível obter dados até a safra 1995/96). Outro elemento que merece destaque nesse "corte" de tempo refere-se à possibilidade de exame do intervencionismo estatal sob dois aspectos: primeiro, enfoca o período no qual esse intervencionismo constituiu-se num elemento fundamental para a implementação do PROÁLCOOL; segundo, incorpora à análise a fase de arrefecimento relativo desse intervencionismo, a partir da extinção do IAA em 1990.

\subsection{HIPÓTESE}

A única hipótese a ser testada neste estudo diz respeito ao fato dos produtores ligados à agroindústria canavieira brasileira estarem inseridos, num primeiro momento, em um paradigma subvencionista; posteriormente, alguns desses produtores passaram a adotar o paradigma tecnológico como forma de definir o que é relevante para uma situação mais concorrencial. Daí uma das razões para a ocorrência da evolução diferenciada verificada na agroindústria canavieira do Brasil.

Define-se paradigma tecnológico "(...) como um 'padrão' de solução de problemas tecno-econômicos selecionados, com base em principios altamente seletos derivados das ciências naturais" (Canuto, 1991, p.318). Nessa mesma linha, parafraseando Canuto (1991), o paradigma subvencionista trata-se também de um padrão de solução de problemas políticos e tecno-econômicos, onde o Estado caracteriza-se, via de regra, como um agente subvencionador do segmento produtivo que recebe o seu auxílio. $\mathrm{Na}$ realidade, o neologismo subvencionista denota um caráter altamente intervencionista, cuja forma de protecionismo estatal - dado através de expedientes como subsídios, quotas de produção, etc - contribui para assegurar a sobrevivência de uma classe, contrariando, assim, as regras de mercado e da concorrência. 


\subsection{JUSTIFICATIVA}

Ao procurar analisar a evolução diferenciada ocorrida na agroindústria canavieira do País, sob a ótica do desenvolvimento tecnológico, e com o instrumental analítico neoschumpeteriano e neocorporatista, espera-se contribuir para a busca de um maior conhecimento sobre o setor em tela, em específico analisando as transformações ocorridas na década de 90 . Além do que, a possível proposição de políticas públicas derivadas deste trabalho também configura-se como fator estimulante para sua realização. Dessa forma, as contribuições do presente trabalho são:

- o emprego do instrumental schumpeteriano e neoschumpeteriano que, acoplado ao neocorporatismo, busca fundamentar a análise da evolução diferenciada da agroindústria canavieira;

- ressaltar e explicar a evolução diferenciada da agroindústria canavieira, com base na hipótese realçada pelo presente trabalho;

- analisar o período pós-extinção do IAA e as tendências atuais;

- identificar algumas medidas do grau de modernização da agroindústria canavieira entre os estados brasileiros (para os anos de 1975, 1980 e 1985); e,

- analisar, através de dados primários obtidos via aplicação de questionários, características importantes da concorrência interfirma verificada na agroindústria canavieira.

\subsection{METODOLOGIA}

A metodologia para testar a hipótese ora realçada requer um referencial teórico que possibilite tratar apropriadamente a dinâmica tecnológica da agroindústria canavieira brasileira e suas transformações. Neste sentido, na execução do presente trabalho utilizam-se as idéias neoschumpeterianas e neocorporatistas, posto serem estas as mais adequadas para a análise do fenômeno contextualizado. $O$ enfoque neoschumpeteriano possibilita avançar, teórica e empiricamente, na identificação dos principais elementos motores da dinâmica capitalista (Possas, 1991); e, o enfoque neocorporatista dá a suficiente flexibilidade para integrar grupos de interesses e Estado na formulação de 
políticas públicas, permitindo analisar como o Estado intervém e como os diferentes grupos de interesses giram em torno deste, tendo como âncora as políticas setoriais (Belik, 1992).

Outrossim, através da utilização da técnica de análise fatorial - que permite obter, por exemplo, medidas do grau de modernização de um setor - pode-se captar melhor de que forma se deu a evolução diferenciada da agroindústria canavieira entre os estados brasileiros.

Para obtenção de dados sobre as estratégias tecnológicas da firma, utiliza-se a técnica de interrogação baseada no envio de questionários via correio. 


\section{REFERENCIAL TEÓRICO}

Este capítulo, compreendido por duas seções, tem como propósito apresentar o referencial teórico apropriado para interpretar os principais condicionantes da evolução diferenciada ocorrida na agroindústria canavieira do Brasil, de 1975 a 1995, destacandose os aspectos centrais da mudança tecnológica e dos arranjos institucionais nessa contextualização. Neste sentido, concebe-se o eixo indústria-mercado da agroindústria canavieira como dinâmico e em transformação. Portanto, ao descrever alguns conceitos tais como mudança tecnológica - que incorporam essas características, são fornecidos elementos para respaldar a discussão sobre o desenvolvimento tecnológico ocorrido no setor em tela.

Antes de especificar as seções que formam este capítulo, torna-se oportuno um breve comentário sobre a revisão de literatura implementada para a escolha do referencial teórico capaz de nortear este trabalho.

Inicialmente, pode-se dizer que um arcabouço teórico unívoco necessário ao entendimento das relações entre a mudança tecnológica, a concorrência interfirmas e o papel do Estado, ainda não se verifica na Teoria Econômica. Entretanto, existem alguns instrumentais analíticos, mutuamente excludentes ou não, que tratam com rigor os vários aspectos do processo de desenvolvimento tecnológico.

Em nosso estudo, a literatura revisada contemplou quatro macro-alternativas possíveis, quais sejam:

- a abordagem neoclássica e seus pressupostos (Hicks, 1932; Hayami \& Ruttan, 1971; Ferguson, 1984; Shapiro, 1981; Schmookler, 1979; Solow, 1979; Mowery \& Rosenberg, 1982; Silva, 1982; Bacha, 1992; e Silva, 1992); 
- o enfoque da literatura sobre a organização industrial (Koch, 1980; Plott, 1989), onde alguns elementos da teoria econômica para o estudo da mudança tecnológica foram considerados, subdividido em estruturas de mercado, barreiras à entrada e dinâmica do oligopólio (Steindl, 1983; Labini, 1980; e Possas, 1987), e as teorias da firma e a relação estratégia-estrutura (Penrose, 1962);

- o terceiro passo consistiu em investigar os determinantes do processo dinâmico de desenvolvimento, da mudança tecnológica e da inovação, com orientação para as análises schumpeteriana (Schumpeter, 1961 e 1982) e neoschumpeteriana (Freeman, 1974; Nelson \& Winter, 1977; Cochrane, 1979; Nelson, 1979; Freeman et al., 1982; Nelson \& Winter, 1982; Dosi, 1984; Canuto, 1995; e Lima, 1996). Adicionalmente, outros temas relativos à mudança tecnológica também foram analisados, quais sejam: o aprendizado tecnológico e as relações usuário-produtor (Rosenberg, 1982); o aprendizado e capacitação tecnológica em países periféricos (Katz, 1972; e Lall, 1994); as relações entre ciência e inovação (Rosenberg, 1982; e Orsenigo, 1989); e os impactos econômicos da mudança tecnológica - o catching-up tecnológico - (Freeman, 1989); e,

- a análise neocorporatista (Schmitter, 1985; Belik, 1992; Soto, 1993; e Saes, 1995).

Através do estudo da literatura acima mencionada, escolheu-se o referencial teórico neoschumpeteriano para interpretar os principais condicionantes da evolução diferenciada ocorrida na agroindústria canavieira do Brasil. Esta escolha baseou-se no fato de que a existência de "gargalos" - problemas técnicos ou de qualquer outra natureza que afetam o processo produtivo - contribui para o surgimento de várias inovações possíveis. No presente estudo, este "gargalo" refere-se a uma forte crise energética mundial ocorrida em 1973 e repetida em 1979 (concomitante a uma forte crise da economia açucareira), que contribuiu para o surgimento de programas de geração de fontes alternativas de energia como, por exemplo, os programas de óleos vegetais, de florestas energéticas (produtoras de lenha e carvão) e do álcool combustível.

Para os neoschumpeterianos, o eixo indústria-mercado, no qual se processa a interação competitiva estratégia versus estrutura é que define as possibilidades e oportunidades tecnológicas em produtos e processos, e as condições de seleção e de apropriabilidade da inovação sob a forma de lucros (Possas, 1991). Neste sentido, o 
approach neoschumpeteriano permite verificar o comportamento das firmas e da estrutura de mercado num quadro dinâmico de mudança técnica, incorporando, de certa forma, a intervenção estatal à análise - posto ser o Estado um interventor direto no padrão de busca de muitas firmas brasileiras (Moreira, M. 1989). Ademais, as idéias neoschumpeterianas são relativamente complementares entre si, o que faz com que não seja necessário eleger um ou outro expoente dessa corrente como referência central para este estudo. $^{2}$

Como o Estado teve (e tem) um papel fundamental na conformação da agroindústria canavieira brasileira (Belik, 1992), reduzir este estudo apenas a fatores como a verificação de que maneira o Estado modificou as condições de rotina, busca e seleção das unidades produtivas dessa agroindústria ou, no tocante às estratégias tecnológicas, verificar até que ponto a proteção estatal - dada via preços garantidos, condições favoráveis de investimento, etc - não estimulou a inovação, significa entender parte do processo de como se deu a política agroindustrial canavieira do País. Entretanto, uma visão mais abrangente do arranjo institucional que gravita em torno dessa agroindústria, ligando interesses organizados com as estruturas de decisão do Estado, pode ser obtida através do uso da análise neocorporatista.

Assim sendo, a análise neocorporatista ora proposta procura complementar a análise neoschumpeteriana, porquanto permite entender como e por que o Estado operacionaliza suas políticas, interagindo com uma série de grupos de interesses, seja dentro do próprio Estado e/ou fora dele. Se a existência do "gargalo" irá proporcionar um ambiente propício para o surgimento de inovações, a "orquestração" de interesses, base da análise neocorporatista, será fundamental para explicar a escolha dentre as alternativas inovadoras existentes.

Após estas notas introdutórias, na seção 2.1 deste capítulo faz-se uma discussão a respeito da teoria de Schumpeter e de seus principais aprofundamentos, a saber: Rosenberg (1969 e 1982), Freeman (1974) e Freeman et al. (1982), Nelson \& Winter

\footnotetext{
${ }^{2}$ Este trabalho não tem como propósito pormenorizar os tratamentos dados pelas abordagens neoclássica e da organização industrial no que respeita à mudança tecnológica, nem de pormenorizar suas limitações nos tratos da inovação e do progresso técnico como processos endógenos à dinâmica econômica. Uma síntese desses aspectos ora ressaltados pode ser encontrada em: Moreira, M. (1989), Silva (1982), Araújo (1989), Salles Filho \& Silveira (1990), Silva (1992), Medeiros (1995) e Shikida \& Lopez (1997).
} 
(1982), Dosi (1984) e Cochrane (1979). Por último, na seção 2.2 procura-se realçar os principais pontos da análise neocorporatista.

\subsection{A TEORIA DE SCHUMPETER E DOS NEOSCHUMPETERIANOS}

Mesmo com a citada presença estatal, a proposição de um estudo da agroindústria canavieira brasileira em um contexto de inovações admite uma ligação, ainda que não exclusivamente, com as idéias de Joseph Alois Schumpeter. A teorização desse economista austríaco acerca da economia capitalista aponta, entre outros aspectos, para o discernimento dos períodos de expansão e contração da economia. A idéia central para o entendimento das mudanças econômicas está, neste caso, na incorporação de inovações no sistema econômico.

"Sendo a economia capitalista um objeto histórico particularmente dinâmico e auto-transformador em sua essência", questionar os métodos estáticos de raciocínio e de análise em Economia é uma forma de tentar evitar o equívoco que se comete na simplificação estática dos processos dinâmicos (Possas, 1991, p.79).

De fato, ampliar a análise econômica do plano estático para o plano dinâmico não é tarefa simples. Schumpeter, ao expor uma nova dialética para o capitalismo ${ }^{3}$, conseguiu com muito rigor fazer tal proeza. O desenvolvimento econômico passa, então, a ser visto como uma mudança espontânea e descontínua na estrutura produtiva existente, fato este preconizado pela teoria dos ciclos de Schumpeter (Araújo, 1989). O desenvolvimento, no sentido proposto por Schumpeter (1982), é definido como a realização de novas combinações, que são as inovações.

As inovações, surgidas em ondas ou aglomerados concentrados no tempo, constituem-se a chave para a explicação dos ciclos pelos quais passa a economia. Segundo Dosi, citado por Cruz (1988), as inovações menores ocorrem como desdobramentos das inovações maiores, sendo aquelas consideradas fenômenos de ajustamento.

\footnotetext{
${ }^{3}$ Resumidamente, a nova dialética do capitalismo acima referida está na possibilidade da grande empresa burocratizada vir a neutralizar o elemento chave do sistema, qual seja: o empresário inovador (empreendedor).
} 
Para Schumpeter (1982), o elemento motriz da evolução do capitalismo é a inovação, seja ela em forma de introdução de novos bens ou técnicas de produção, ou mesmo através do surgimento de novos mercados, fontes de oferta de matérias-primas ou composições industriais. O indivíduo que implementa essas novas combinações, inserindo as inovações no sistema produtivo, é o inovador, podendo este ser ou não o inventor. $\mathrm{Na}$ realidade, o fato de o inovador confundir-se com outras funções é irrisório. Não é a propriedade o ponto fundamental em questão, e sim a liderança (Ekerman \& Zerkowski, 1984). Assim sendo, Schumpeter (1982) classifica de empreendimento a realização de combinações novas, e empresários inovadores os indivíduos cuja função é realizá-las. Neste ínterim, é preciso ressaltar que se tais combinações não forem levadas à prática, não são economicamente relevantes para a sociedade. Além disso, o empresário, no sentido schumpeteriano, assume um caráter independente, não constituindo uma classe social. "É mais conveniente dizer que uma pessoa 'está' empresário do que 'é' empresário" (Almeida, 1995, p.6).

Faz-se necessário destacar que todo esse processo de progresso técnico, além de adquirir uma multiplicidade de formas, é um fenômeno endógeno por natureza, isto é, as raízes de suas ondas encontram-se dentro da própria estrutura do sistema econômico. Para Possas (1991, p.82), "a presença de agentes que visam os lucros, 'extraordinário' ou não, torna essencialmente endógeno o aparecimento de inovações, que constituem o mecanismo, por excelência, de alterar as condições do ambiente econômico, tornando 'cruciais' as decisões capitalistas de investir (...)."

É preciso distinguir a capacidade que a firma tem para "endogeneizar" o processo de geração de uma inovação (no qual os mecanismos internos das economias capitalistas dão origem aos ciclos econômicos), com os fatores externos à própria firma, sujeitos às intempéries do sistema. Exemplificando: a abertura de um novo mercado, baseada na tomada de decisões de capitalistas e inovadores, revoluciona a estrutura econômica a partir de dentro. Contudo, é perfeitamente aceitável que esta abertura tenha sido motivada, total ou parcialmente, por uma crise em outro segmento da economia, externo àquele onde ocorreu a inovação. Ou seja, a flutuação de mercado serve como elemento para fortalecer ou não a adoção de uma determinada inovação, enquanto a endogenia do processo de inovação, segundo Schumpeter (1982), está ligada às decisões estratégicas que as firmas tomam diante de um quadro econômico de incertezas. 
A procura do lucro, através da inovação, é fundamental na transformação da situação estática em processo de dinâmica econômica. Segundo a teoria schumpeteriana, sem o lucro não poderia haver nenhuma acumulação de riqueza e, consecutivamente, nenhum desenvolvimento. "O lucro, por definição originado da inovação, é a parte básica da fortuna capitalista. É a 'acumulação primitiva' schumpeteriana" (Ekerman \& Zerkowski, 1984, p.216). A relação lucro-função empresarial-inovação revoluciona a estrutura econômica a partir de dentro (Schumpeter, 1982).

Neste contexto, a introdução de uma inovação, desde que seja absorvida pelo mercado, implica em um novo dinamismo para a economia. Os lucros advindos dessa inovação contribuem para acirrar a competição capitalista, atraindo para o mercado o que Schumpeter denomina de imitadores. Ou seja, pessoas que, via de regra, investem recursos naquilo que foi criado pelo inovador. Nesse primeiro momento, elevam-se as taxas de investimento, nível de emprego e crescimento da economia.

Em um segundo momento, a oportunidade de realização de altos lucros na área associada à inovação é reduzida, haja vista a tendência de aumento de oferta que ocorrerá nessa ocasião. Neste caso, acirra-se a "concorrência de preços à medida que o processo de inovação se generaliza e os frutos da introdução do novo método não aparecem nas mãos dos individuos na magnitude que esperavam quando o introduziram" (Camara, 1993, p.21). Nesse cenário, a redução dos investimentos e a baixa da oferta de emprego são fatores logo incorporados. Embora possa ser projetada uma tendência ao equilíbrio, isto não chega a ocorrer, pois, segundo Schumpeter, citado por Shapiro (1981, p.571), "tal atividade é desigual, descontínua, desarmoniosa por natureza, sendo esta desarmonia inerente ao modus operandi dos fatores de progresso." Além do que, o processo de desenvolvimento econômico é visto por Schumpeter (1982) como dinâmico e em transformação, sobretudo pelo caráter assimétrico das inovações no interior desse processo. Deve-se mencionar, também, que implícito neste ponto está a ruptura de Schumpeter com a situação de equilíbrio proposta por Walras (Calazans, 1992).

Dentro das ondas de inovação e mudanças econômicas observadas em Schumpeter cabem algumas considerações importantes. As inovações tendem a concentrar-se em alguns setores da economia, em particular nos mais fortes, e seu processo de difusão é eminentemente desigual. Segundo Koch (1980, p.214-215): 


\begin{abstract}
"Schumpeter foi talvez o primeiro economista a arguir persuasivamente que inovações tecnológicas requerem a existência de grandes firmas (algumas das quais possuem consideráveis poderes de mercado) e que ambas, geração de inovações e taxa de difusão destas inovações, serão aumentadas se as firmas estiverem dando pequenos aumentos na proteção e poder de mercado como um resultado da inovação."
\end{abstract}

Evidentemente, as firmas com maior probabilidade de inovar procurarão manterse na dianteira do progresso técnico, introduzindo novas inovações, a fim de não se tornarem vítimas desse processo inovativo (Moreira, M. 1989). Para Schumpeter (1961), o processo de mudanças tecnológicas que revoluciona incessantemente a estrutura econômica a partir de dentro, criando elementos novos e destruindo o antigo, é o processo de "destruição criadora".

Sendo insuficientes as poupanças geradas pelo fluxo circular da economia, há a necessidade de se recorrer ao crédito para fornecimento dos recursos demandados pelo inovador (Schumpeter, 1982). A fonte desses recursos pode advir da capacidade que os bancos têm de criar poder de compra, através do multiplicador bancário, e/ou dos fundos gerados pelas inovações que lograram sucesso.

A ligação entre as inovações e o crédito é de fundamental importância para esta abordagem. Segundo Schumpeter (1982), o crédito é essencial ao processo econômico, pois parte das inovações são financiadas com recursos de terceiros. Vale dizer, o empresário inovador necessita de crédito. "A concessão de crédito opera como uma ordem para o sistema econômico acomodar os propósitos do empresário, como um comando sobre os bens de que necessita: significa confiar-lhe forças produtivas" (Schumpeter, 1982, p.74).

Shapiro (1981) examina o crédito em Schumpeter distinguindo dois momentos, quais sejam: expansão e contração. Durante a expansão, as inovações financiadas, em parte pelo crédito bancário, reúne o superotimismo com especulação. Verifica-se aí a chamada inflação creditícia, de caráter transitório. Durante a contração, onde costuma ocorrer falências de empresas que malograram-se no ajustamento às variações das inovações, inclui-se uma redução geral do crédito e uma baixa nos preços. Na medida em 
que os empresários vão saldando suas dívidas, o processo deflacionário recrudesce ainda mais.

O fornecimento de crédito, por sua vez, é função dos capitalistas. Embora o empresário inovador seja o indivíduo pioneiro na introdução de novos processos, produtos ou formas de organização, sendo por isso tomador de crédito, ele não é um tomador de riscos. $\mathrm{Na}$ abordagem schumpeteriana quem concede o crédito é quem sofre os reveses do investimento, posto que o risco não faz parte da função empresarial e sim da função capitalista (Ekerman \& Zerkowski, 1984). O crédito assume, dessa forma, um papel auxiliador na separação entre o empresário e o capitalista (Almeida, 1995).

Este tipo de afirmação pressupõe que o empresário não seja o proprietário do capital. É interessante observar, contudo, que apesar dos empresários não serem tomadores de riscos, eles podem ter ligações temporárias com empresas individuais, como os financistas ou empreendedores (Oser \& Blanchfield, 1983). Neste sentido, "o inovador pode também ser um capitalista, mas ele é um tomador de riscos somente quando for também capitalista" (Shapiro, 1981, p.569). Segundo Schumpeter (1982, p.92-93), "mesmo que o empresário se autofinancie pelos lucros anteriores, ou que contribua com os meios de produção pertencentes ao seu negócio 'estático', o risco recai sobre ele enquanto capitalista ou possuidor de bens, não enquanto empresário".

O juro decorrente do financiamento de uma inovação é um fenômeno do valor "o excedente que constitui a base do juro, sendo um excedente de valor, só pode surgir como uma expressão do valor" (Schumpeter, 1982, p.123) - e um elemento do preço, funcionando como uma espécie de imposto sobre o lucro empresarial. Assim sendo, pode-se considerar o juro, em Schumpeter, como tendo origem, afora fricções ou monopólios, na atividade inovadora (Cruz, 1988), ou seja, no próprio lucro empresarial. Fica claro o relacionamento do juro com o processo de desenvolvimento schumpeteriano, na medida que a atividade inovadora for capaz não só de gerar o lucro, como também o pagamento do juro (que representa a remuneração do capitalista).

Sobre o capital, Schumpeter (1982) o define como um elemento na economia de trocas, um expediente com o qual o empresário submete ao seu domínio os insumos de que precisa para possibilitar a realização de novas combinações. Trata-se, pois, da soma 
de meios de pagamentos (fundo de poder aquisitivo) que está à disposição para a transferência aos empresários.

Para Schumpeter, os ciclos na economia possuem quatro fases: prosperidade, recessão, depressão e recuperação. As fases de recessão e recuperação, intermediárias aos dois pólos de alta e baixa (prosperidade-depressão) e baixa e alta (depressãoprosperidade), estariam, respectivamente, ligadas às tendências de queda e retomada dos investimentos - implícito na exposição de crédito feita anteriormente por Shapiro (1981). Quanto às duas outras fases, a prosperidade envolveria o surgimento das inovações e com elas a busca crescente por lucros. A depressão, ao revés, envolveria o término do processo de difusão das inovações, onde verificariam-se falências e deflação geral. Para Cruz (1988), na fase de depressão dos ciclos ocorrem as quebras de firmas industriais, comerciais e do setor financeiro, fenômenos estes característicos do que Schumpeter chama de crise. Uma parte dessas quebras provém do desuso de produtos e processos decorrentes da inovação, sendo isto a "destruição criadora". Conforme Schumpeter (1982), a "destruição criadora" é essencial ao capitalismo porquanto possibilita a ocorrência de movimentos que alteram o estado de equilíbrio.

Os períodos de expansão e contração da economia não são, para Schumpeter, infinitos. Ao contrário, sua predição diz respeito a uma perspectiva de decadência do capitalismo. As forças que agiriam para tal derrocada seriam basicamente duas: primeiro, o empresário inovador estaria despersonalizando-se frente à grande empresa burocratizada; segundo, os arranjos institucionais da sociedade não estariam se adequando às instabilidades do sistema capitalista.

Em Oser \& Blanchfield (1983) constata-se que o capitalismo de Estado - definido por Schumpeter como a propriedade governamental e o controle de alguns setores da economia, além da iniciativa governamental nas empresas nacionais e estrangeiras padecerá de atrito e ineficiência, segundo o próprio Schumpeter.

É incontroverso que a aversão de Schumpeter ao papel ativo do Estado na economia esteja associada à sua formação liberal. Neste contexto, pode-se asseverar que as idéias schumpeterianas não têm qualquer afinidade com a teoria keynesiana. $\mathrm{Na}$ verdade, as idéias schumpeterianas atuam como uma alternativa à intervenção estatal preconizada pelo keynesianismo (Schumpeter, 1982). Em Galbraith (1989, p.215), 
constata-se que Schumpeter condenou veementemente a teoria keynesiana: "entre as deficiências e falhas mais graves de Keynes, na opinião de Schumpeter, estava a insistência em unir teoria econômica e medidas práticas." O confronto de Schumpeter e Keynes fica mais claro a partir do momento em que o primeiro, em plena Grande Depressão, insistiu para que nada fosse feito, ou seja, a depressão seguiria seu próprio curso até exaurir-se por si mesma (Galbraith, 1989). Apesar dessa diferença entre Keynes e Schumpeter, estes autores também guardam similitudes. Como sugere Cruz (1988), essa semelhança pode ser observada quanto ao caminho de rompimento do fluxo circular. Para Schumpeter, a introdução de uma inovação provoca a ruptura do fluxo circular. Isto, no entanto, exige um aprofundamento na questão do crédito e da moeda para explicação de como se dará o virtual investimento nessa inovação. Keynes também considera o investimento como sendo uma variável de suma importância no sistema econômico, enfatizando neste ponto o papel da liquidez e da moeda no sistema capitalista. Outra semelhança reside no animal spirit que está por trás do comportamento do investidor, em Keynes, e no "espírito empreendedor" do empresário que realiza a produção, em Schumpeter (Cruz, 1988).

De qualquer modo, sendo o Estado um "elemento" que assumiu (e ainda assume) certa importância na determinação do comportamento de vários setores da economia brasileira, atuando muitas vezes como fornecedor de crédito e/ou absorvedor do risco, é possivel divergir de Schumpeter e procurar, a fortiori, analisar o Estado como um "elemento" capitalista nesse processo.

Não obstante as idéias de Schumpeter terem sido elaboradas para explicar as flutuações de uma economia, é possivel adaptar algumas de suas argumentações para explicar as flutuações de um setor específico dessa economia, como o da agroindústria canavieira. Neste caso especial, o Estado aparece como o agente que proporcionará o surgimento de um novo mercado (do álcool combustível), sendo o principal fornecedor de crédito necessário à produção de álcool.

Essa constatação, por sua vez, remete a presente análise para algumas contribuições ao legado de Schumpeter, seja para fornecer elementos para enriquecer seu enfoque dinâmico, como também adaptá-lo melhor aos fenômenos presentes da realidade, sobretudo no que se refere ao papel do Estado, assunto este a ser tratado nas próximas partes deste estudo. 


\subsubsection{PRINCIPAIS APROFUNDAMENTOS DO REFERENCIAL} ANALÍTICO NEOSCHUMPETERIANO

O papel das inovações como elemento fundamental para o entendimento da dinâmica capitalista foi o grande feito de Schumpeter. Vários aprofundamentos sobre a teoria schumpeteriana (realizados por autores comumente chamados de neoschumpeterianos) surgiram, gerando novas alternativas para o tratamento da inovação e do progresso técnico.

Esta parte do trabalho destaca alguns expoentes da linha neoschumpeteriana, dando especial atenção a: Nathan Rosenberg, Christopher Freeman, Richard R. Nelson \& Sidney G. Winter, Giovanni Dosi e Willard W. Cochrane. Rosenberg (1969 e 1982) trabalha com a idéia de "gargalos", que exigem soluções capazes de contribuírem para dinamizar a economia. Freeman (1974) e Freeman et al. (1982) revelaram as características básicas das estratégias tecnológicas que as empresas adotam. Nelson \& Winter (1982) evidenciam que a concorrência schumpeteriana tende a produzir vencedores e perdedores, onde algumas firmas tirarão maior proveito das oportunidades técnicas do que outras, dependendo evidentemente do tipo de estratégia tecnológica usada por cada firma. Dosi (1984) complementa a idéia de estratégia tecnológica com a idéia de um padrão de solução de problemas técnico-econômicos, denominado paradigma tecnológico. E Cochrane (1979) adaptou algumas idéias schumpeterianas à área agrícola.

\subsubsection{ROSENBERG}

Dentre os expoentes da linha neoschumpeteriana, Nathan Rosenberg destaca-se por realcar importantes pontos sobre o processo de mudanca tecnológica e por assinalar a influência que o nivel de aprendizado exerce sobre o rumo da mudança tecnológica.

Para Rosenberg (1969), no processo dinâmico do desenvolvimento tecnológico, o surgimento de desajustes ou desequilibrios torna-se um elemento fundamental para a introdução de uma mudança técnica que possa alavancar o crescimento econômico. Desequilíbrios entre os vários elementos no sistema criam os pontos de estrangulamentos que concentram a atenção de cientistas, inventores, empresários, administradores públicos etc, na solução de problemas de alocação mais eficiente dos recursos. 
Neste contexto, Rosenberg (1969) sugere uma teoria de mudança técnica induzida baseada na necessidade óbvia e obrigatória de superar as restrições sobre o crescimento ao invés da escassez relativa de fatores e de seus preços relativos. Nas indústrias e nas empresas os inovadores irão procurar resolver os problemas do processo produtivo ("gargalos" que exigem soluções). Em geral, pode-se dizer que "os trabalhos $e$ inspirações dos tecnólogos e engenheiros nasciam de pressões provocadas pelo processo produtivo" (Araújo, 1989, p.20). A ineficiência da caldeira a vapor, por exemplo, conduziu à formulação das leis da termodinâmica. Isto age como mecanismo de transmissão de mudança técnica de um processo para o seguinte.

De acordo com Salles Filho (1993, p.89):

"Rosenberg (1969) chamou atenção para o fato de
existirem imperativos tecnológicos que levam a que o
desenvolvimento tecnológico esteja normalmente focado mais
em certas direções que em outras, muitas vezes em função de
gargalos tecnológicos concretos que indicam um certo
caminho de busca de soluçães, que estarão balizadas pelo
estado do conhecimento relativo àquela tecnologia ou àquele
conjunto de tecnologias. Rosenberg chamou este fenômeno de
focusing devices".

Convém apontar que para Rosenberg (1969) a atividade inovativa comporta-se como um procedimento de busca, onde os resultados daí derivados não são conhecidos ex-ante. Dessa forma, as decisões de inovação e investimento, orientadas em relação ao futuro, envolverão inevitavelmente um relativo grau de incerteza (Rosenberg $\&$ Frischtak, 1983).

Como regra geral, no início do paradigma ocorre a idéia de que as expectativas decorrentes de uma mudança tecnológica serão maiores. Ao revés, na fase final de um paradigma ocorre a idéia de que as expectativas serão menores. De fato, o grau de incerteza é muito forte nos momentos iniciais de um paradigma, o que contribui para que as expectativas sejam, neste caso, maiores. Como corolário disto pode-se afirmar que o pioneirismo (nas inovações) pode ser vantajoso em determinadas ocasiões - dependendo evidentemente de cada ocasião. Não obstante, é importante ressaltar que isto não se trata de uma regra, nem de um condicionante suficiente para um virtual domínio de mercado. Além disso, nesse processo o produtor enfrenta uma forte contradição, qual seja: ele deve 
persuadir os compradores potenciais da estabilidade do produto, fazendo com que a demanda por este seja satisfatória; pari passu ao fato de ter sempre que pesquisar, visando dessa forma incorporar maiores avanços tecnológicos ao seu produto, de modo a torná-lo mais competitivo.

Neste dilema, verificam-se duas questões de ordem institucional: pode ocorrer a padronização prematura, o que implica em perda de melhoramentos em uma determinada inovação; como pode ocorrer a padronização tardia, o que implica em perda do poderio de divulgação da inovação.

Realmente, a decisão é deveras complicada. Esperar ou adotar uma inovação? Eis o dilema! A incerteza está na base da dificuldade apresentada. Entretanto, geralmente o indivíduo efetivará uma aposta: um direcionamento (sujeitando-se à sorte) em se tratando do espírito empreendedor do empresário schumpeteriano; ou uma intuição baseada no animal spirits do empresário keynesiano. "No lado das expectativas tem-se o que Keynes chama de animal spirits dos empresários, fundado na motivação básica do capitalismo: acumular, acumular e acumular" (Keynes, 1983; p.XV).

Três aspectos importantes foram acentuados por Rosenberg (1969 e 1982). Primeiro, sua argumentação contrapõe-se a determinados postulados neoclássicos, partindo da negação, em especial, da racionalidade maximizadora - a atividade inovativa é realizada sob condições de incerteza, o que não ocorre nos modelos neoclássicos. Ademais, as mudanças nos preços relativos dos fatores de produção não se configura em um incentivo para as invenções; sobretudo para uma invenção de um tipo particular dirigido a economizar o uso do fator que se acha relativamente custoso. Segundo, ficou evidente para esse autor que o processo de mudança tecnológica envolve relações complexas, onde os resultados não são conhecidos ex-ante e onde a taxa de adoção de uma tecnologia ou mesmo sua direção estão ligadas às expectativas quanto ao futuro do progresso tecnológico. E, terceiro, o nível de aprendizado influi diretamente no rumo da mudança tecnológica.

$\mathrm{Na}$ realidade, o terceiro aspecto citado por Rosenberg (1982) permite verificar a possibilidade de separação do processo de inovação tecnológica em dois momentos geração e difusão - a partir do conceito de learning-by-using (LBU) e learning-by-doing (LBD). 
A idéia geral do learning está associada ao processo de aprendizado tecnológico, cujo aperfeiçoamento advém do processo de difusão. Para Rosenberg (1982), no caso do LBU tem-se o resultado derivado do aprendizado via uso, que é conscientemente perseguido, e que é revertido numa melhoria das condições de produção e uso de um produto. No caso do LBD o resultado é derivado do aprendizado via processo produtivo, que pode surgir mediante a existência de "gargalos" nesse processo. O LBD consiste no desenvolvimento cada vez maior da habilidade nos estágios de produção. De fato, à medida que a tecnologia for se aperfeiçoando com a produção acumulada e/ou advindas do uso do produto - fruto de melhorias implementadas no decorrer da atividade produtiva - ocorrerá a redução dos custos por unidade produzida. Daí a importância dos gastos com P\&D e com as inovações propriamente ditas.

Outrossim, pode-se considerar a participação ativa dos usuários como a característica mais premente na distinção entre o LBD e LBU. Ou seja, no LBD o enfoque concentra-se no lado do produtor, enquanto no LBU o enfoque concentra-se no lado do usuário, isto é, no uso mais eficiente do equipamento e/ou produto. Ademais, cabe frisar que existem dois tipos de LBU: o incorporado - embodied - (a interação que se estabelece entre o produtor e o usuário pode levar a uma otimização); e o desincorporado - disembodied - (o usuário vai aprender por si só). Em essência, na perspectiva tanto do LBU como do LBD, o que deve ficar claro é o fato do nível de aprendizado exercer grande influência na direção e grau de exploração de uma determinada tecnologia (Rosenberg, 1982).

Segundo Lundvall (1988), essa cooperação entre usuário e produtor tem a sua importância para a análise do processo de inovação. Dentre as razões para os produtores se aproximarem dos usuários, e vice-versa, destacam-se: o produtor passa a monitorar o usuário, dando-lhe especial atenção a fim de saber os possíveis limites e potencialidades que o uso do seu produto propicia - a monitoração possibilitará uma avaliação do grau de capacidade técnica do usuário -; e, podem ocorrer casos onde o usuário apresente também um outro processo de fabricação que possa gerar novas técnicas ao produtor - 0 conhecimento produzido pelo LBU pode localizar "pontos de estrangulamento", aumentando o tempo de vida útil do capital fixo e reduzindo custos.

Rosenberg (1982) parte do princípio (schumpeteriano) de que as inovações ocorrem num ambiente de incerteza, fato este que torna problemática a questão do timing 
da adoção. Neste contexto, as expectativas tecnológicas implicam em dois pontos de fundamental importância:

1) retardar a adoção, haja vista a sempre pertinente expectativa de evolução futura da tecnologia - existe uma certa trajetória da tecnologia, a qual Nelson \& Winter (1982) irão qualificar de trajetória natural, enquanto Dosi (1984) denominará de trajetória tecnológica -; e,

2) alterar as especificações de acordo com o grau da obsolescência tecnológica, ou seja, é necessário um ajustamento das especificações que o mercado necessita (uma adequação entre o tempo de vida útil e a obsolescência tecnológica). Neste ponto está implícita a lógica da "destruição criadora" de Schumpeter.

O enfoque do LBU está mais vinculado com as inovações menores (ou incrementais, que podem ser consideradas como fenômenos de ajustamento, ou como desdobramentos das inovações maiores dentro dos paradigmas e trajetórias naturais préestabelecidas) do que com as inovações maiores (ou radicais, aquelas que criam novos paradigmas). O LBU, de maneira peculiar, torna problemática a questão da separação entre geração e difusão. Dois pontos realçam-se neste cenário, a saber:

1) o LBU afetará as expectativas, ou seja, existe a expectativa de que pode ocorrer uma redução do custo via processo de aprendizado;

2) o LBU afetará a difusão - nos processos de aprendizado têm-se a melhoria da tecnologia.

Portanto, a distinção entre o momento da geração e da difusão torna-se problemática a partir deste contexto.

O esquema a seguir procura retratar alguns aspectos ora salientados: 


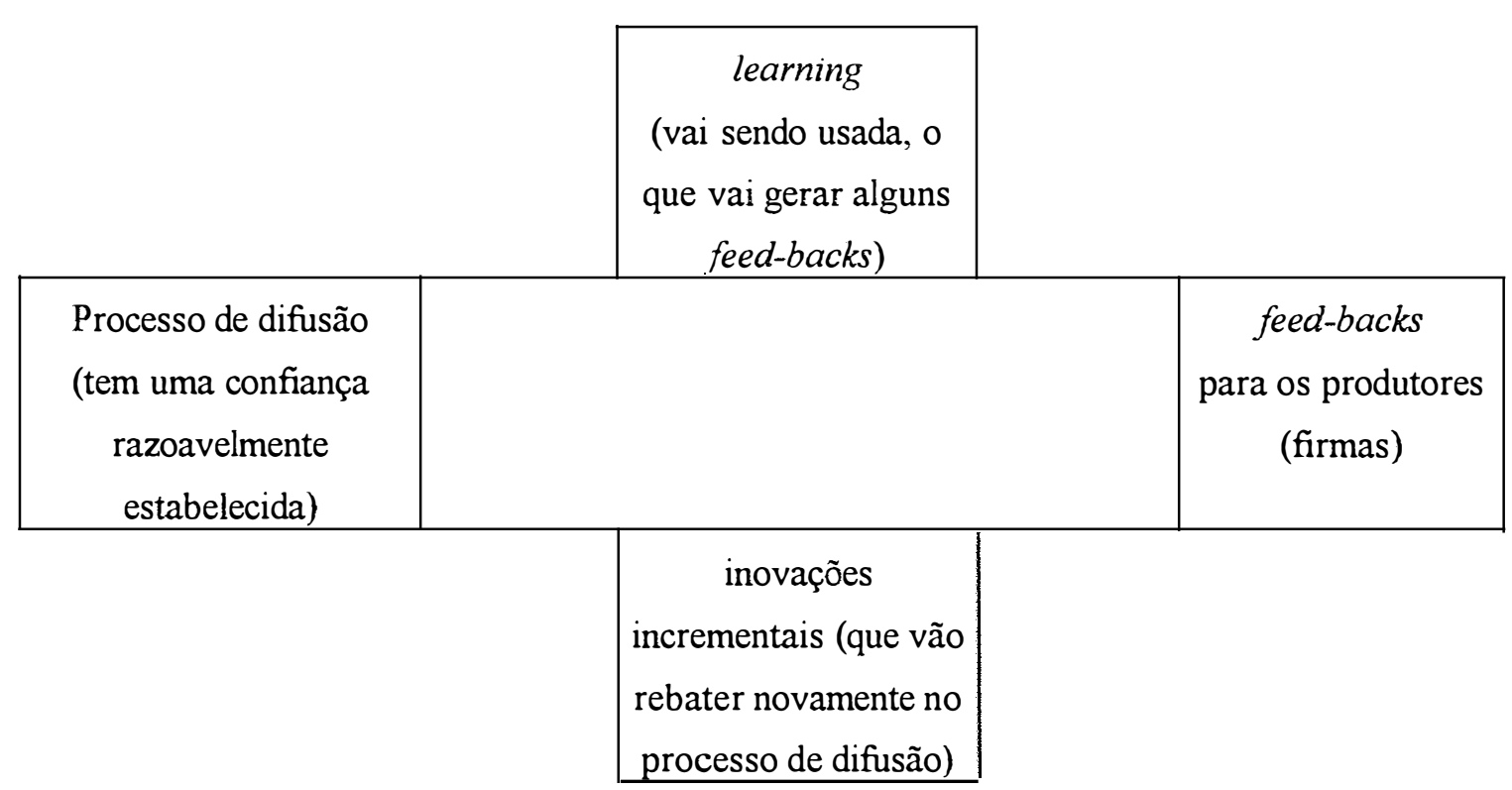

Figura 1 - Esquema simplificado de um learning-by-using (LBU).

No circuito exposto estão embutidas as expectativas, cuja natureza é desconhecida, ou melhor, vai depender de cada caso (o LBU não é generalizável). Observa-se, também, que as decisões internas da firma afetam o processo de adoção e difusão da tecnologia, destacando-se aí a própria capacidade da firma em "endogeneizar" esses processos - no qual o mercado atua como uma espécie de fornecedor de feed-backs ao processo inovativo (Salles Filho \& Silveira, 1990). Este é, digamos, um dos elementos-chave para o questionamento e $\mathrm{m}$ foco: ou seja, tanto a geração como a difusão da inovação irão depender das decisões estratégicas das firmas - algumas vezes beneficiada pela relação usuário-produtor -, isto em um ambiente caracterizado por processos dinâmicos de concorrência.

Ressalta-se, deste modo, a dificuldade de separação do processo de inovação tecnológica em seus dois momentos supracitados (geração e difusão) devido, sobretudo, à sua inconsistência (como processos independentes) no processo endógeno de desenvolvimento tecnológico. Contudo, nesta discussão outros aspectos (que estão imbricados com a temática em destaque) passam a merecer especial atenção. Dentre estes, citam-se: o nível de aprendizado (LBU e LBD) influi na direção da mudança técnica; o fato das inovações ocorrerem em um ambiente de incerteza - o que torna 
problemática a questão do timing da adoção e, conseqüentemente, a própria separabilidade entre geração e difusão; a definição do momento em que se encontra o paradigma tecnológico passa a ser um determinante na caracterização da velocidade de uma expectativa; e o enfoque do LBU está mais vinculado com as inovações menores do que com as inovações maiores, na qual a relação usuário-produtor passa a ter um maior interesse.

As idéias de Rosenberg permitem algumas associações com a temática deste trabalho. Por exemplo, a conjugação das crises mundiais do petróleo e da economia açucareira foram fundamentais para permitir um novo caminho de crescimento para a agroindústria canavieira, que foi a criação e ampliação do PROÁLCOOL. De igual forma, houve a necessidade de persuadir os compradores potenciais da validade técnicoeconômica da mistura gasolina-álcool anidro, ao mesmo tempo em que se desenvolviam pesquisas para viabilizar o uso do álcool hidratado como combustível único. Além disso, a idéia geral do learning, associada ao processo de aprendizado tecnológico, mostra em que sentido se deu a melhoria das condições de produção em termos de usinas e destilarias e também de outros estabelecimentos ligados indiretamente à agroindústria canavieira, como a indústria automobilística.

\subsubsection{FREEMAN}

Christopher Freeman concentrou esforços na questão da tecnologia e de seu importante papel para as empresas (Freeman, 1974; Freeman et al., 1982). No tocante às estratégias tecnológicas verificadas nas empresas, este autor apresentou a seguinte classificação ${ }^{4}$ : ofensiva, defensiva, imitativa, dependente, oportunista e tradicional.

A estratégia ofensiva é caracteristicamente intensiva em P\&D - Pesquisa e Desenvolvimento - e com elevado nível de pesquisa aplicada. Adotando esta estratégia, a firma objetiva a liderança técnica e de mercado a partir do lançamento de novos produtos. Para tanto, além de atentar-se para a questão do conhecimento científico - que pode ser gerado internamente ou a partir de outras fontes -, a firma preocupa-se também com o sistema de patentes.

\footnotetext{
${ }^{4}$ Esse ponto também é tratado por vários autores, ver, a propósito: Araújo (1989) e Camara (1993).
} 
A estratégia defensiva é também intensiva em P\&D, mas a empresa usa esta estratégia para evitar um distanciamento tecnológico significativo, pois é avessa ao risco, não optando desta feita pelo lançamento de novo produto no mercado e, sim, pelo ajustamento técnico-legal às inovações introduzidas. A empresa preocupa-se com o fator concorrencial e institucional do mercado, destinando atenções especiais para as áreas de vendas, publicidade, treinamento e patentes.

A estratégia imitativa é por excelência copiativa, onde a firma busca competir com firmas mais capacitadas através de custos menores. Neste sentido, ao invés de investir em P\&D, a firma direciona atenções especiais para o sistema de informação e seleção de itens para a geração de tecnologia própria, precisando repetidas vezes de trabalhar aspectos institucionais e legais de licença e know-how.

Com a estratégia dependente a firma não possui atividade de $\mathrm{P} \& \mathrm{D}$, pois estabelece relação de dependência institucional e/ou econômica com outras firmas. Devido a esta subordinação, a firma aplica recursos na produção e no marketing, pois costumeiramente é assessorada pelos clientes ou pela matriz.

$\mathrm{Na}$ estratégia oportunista a firma busca preencher nichos de mercado, não desenvolve atividade de $\mathrm{P} \& \mathrm{D}$ e depende, basicamente, do feeling de uma pessoa - ou grupo de pessoas - capaz de analisar conjunturas de mercado.

Com a estratégia tradicional a firma não possui atividade de $\mathrm{P} \& \mathrm{D}$, pois sua área de atuação é em mercados próximos à concorrência perfeita - isto é, atomizados - ou oligopolizados, onde a concorrência geralmente não estimula a inovação. As técnicas de produção nesse segmento normalmente são de conhecimento comum.

Segundo Araújo (1989), a classificação proposta por Freeman abrange firmas tanto engajadas em ondas primárias (o empresário na atividade de inovação), secundárias (os seguidores desse empresário) e setores não atingidos por uma grande mudança técnica, no sentido schumpeteriano.

Para Camara (1993), as estratégias relativas à inovação tecnológica possibilitam uma aproximação da diversidade e natureza dos grupos estratégicos que vigoram em cada indústria. Dessa forma, torna-se possível com a operacionalização do conceito de 
grupos estratégicos de empresas, proposto por Freeman (1974), analisar o desempenho de um segmento específico da economia. Esta proposta foi efetivada por Camara (1993) no estudo da indústria farmacêutica brasileira. Nesse trabalho, a autora classificou as empresas multinacionais ligadas à indústria farmacêutica como: ofensivas (bastante intensivas em $P \& D$, detêm a liderança técnica do setor), defensivas (intensivas em P\&D, porém, mais avessas ao risco) e dependentes (subsidiárias de multinacionais, cujas políticas são subordinadas às estratégias da matriz). Quanto às empresas nacionais ligadas a indústria farmacêutica, devido às suas peculiaridades, Camara (1993) apresentou a seguinte classificação: "agressivas" (possuem qualidades tecnológicas acumuladas ligadas ao aprendizado - learning-by-doing e learning-by-using -, possuem vantagens significativas em termos de vendas e vantagens derivadas da política nacional para o setor - proteção alfandegária, reserva de mercado, etc); imitativas "fortes" (possuem menores vantagens em termos de vendas, se beneficiam da política nacional setorial para avançar em sua trajetória tecnológica via cópia e desenvolvimento interno); imitativas (mesmas qualidades das empresas imitativas "fortes", mas, em menor grau); tradicionais (reduzido dinamismo tecnológico e escassos recursos financeiros, atuação em mercados atomizados); e, marginais (mesmas qualidades das empresas tradicionais, mas, em menor grau).

Vê-se que, para analisar o desempenho e a conduta das empresas, a classificação proposta por Freeman (1974) apresenta-se como de grande utilidade. Especificamente para o nosso estudo, torna-se importante verificar quais foram as estratégias tecnológicas adotadas pelas empresas da agroindústria canavieira, em particular, para aquelas que mais se destacaram no setor.

\subsubsection{NELSON \& WINTER}

Um importante referencial explicativo para a análise dinâmica do processo de mudança tecnológica foi desenvolvido por Richard R. Nelson \& Sidney G. Winter (rotulados pela literatura pertinente como evolucionistas, um segmento neoschumpeteriano).

Como ficou conhecido, o instrumental analítico de Nelson \& Winter (1982), inspirado no mecanismo de evolução das espécies via mutações genéticas em que são 
submetidas à seleção ambiental (Camara, 1993), enfatiza o comportamento da firma explicado por meio das idéias de rotina, busca e seleção. Depreende-se disto o uso de analogias biológicas como uma das mais destacadas marcas de Nelson \& Winter (1982). Destarte, nesta parte do trabalho procurar-se-á ordenar alguns aspectos do instrumental analítico proposto pelos autores supracitados, de forma a elucidar as implicações decorrentes da adaptação de conceitos como rotina, busca e seleção para um ambiente concorrencial entre as firmas.

Para Nelson \& Winter (1982), a concorrência schumpeteriana tende a produzir vencedores e perdedores, onde algumas firmas certamente tirarão maior proveito das oportunidades técnicas do que outras. A tendência a um aumento no grau de concentração ocorrerá à medida que esse processo avançar, posto que o crescimento conferirá vantagens aos vencedores, enquanto o declínio produzirá obsolescência técnica e mais declínio aos perdedores.

Neste panorama caracteristicamente competitivo, as firmas apresentam determinados padrões de crescimento que são assimiláveis à rotina, sendo o análogo biológico de rotina a carga genética; para o processo de busca (mudanças de rotina) temse a mutação; e, para o mecanismo de seleção tem-se o meio ambiente. Segundo Araújo (1989, p.27), "as firmas arrastam através do tempo certas rotinas que são caracteres hereditários (genes); apresentam mutações quando inovam; agem sobre o ambiente quando fazem seleção econômica de alternativas." É sabido, no entanto, que o próprio Schumpeter já fazia alusões às analogias biológicas. Como, por exemplo: "a abertura de novos mercados estrangeiros e domésticos, e a organização da produção, da oficina do artesão a firmas, como a U.S. Steel, servem de exemplo do mesmo processo de mutação industrial - se é que podemos usar esse têrmo biológico (...)" (Schumpeter; 1961, p.105106 - grifo nosso).

A rotina é o conjunto de técnicas e processos organizacionais que caracterizam o modo através do qual as mercadorias e serviços são produzidos, desde as atividades cotidianas até as inovativas (Nelson \& Winter, 1977). Conquanto as rotinas retratem o comportamento e a capacitação organizacional de uma firma (Camara, 1993), sua classificação pode ser feita da seguinte maneira: operação (dia-a-dia da planta); investimento (fazer um projeto, montar uma planta, etc); e, transformação (dão origem às mutações, projeto de P\&D). 
De acordo com Nelson \& Winter (1982, p.400), "(..) o processo de busca compreende as atividades organizacionais que estão associadas com a avaliação de rotinas correntes, que podem levar à alteração destas. "Logo, a busca, a que se referem esses autores, tem um certo sentido, não sendo, por conseguinte, um evento aleatório. Quer dizer, as firmas buscam determinadas estratégias definidas dentro dos contornos de um paradigma.

Nelson \& Winter (1982), citado por Salles Filho (1993, p.89), esclarecem:

"O resultado do processo de busca é não apenas uma inovação de uso imediato, como também um ponto de partida para empreender futuros processos de busca, devido à competência estabelecida naquele campo específico e devido à existência de inovações possíveis (e não previamente conhecidas) na vizinhança da tecnologia desenvolvida."

O processo de busca contempla três tipos de comportamentos, quais sejam: imitação, intramuros e extramuros. No primeiro caso, a firma esboça um tipo de comportamento a partir do modelo de uma firma concorrente nesse mesmo tipo de atividade, isto é, uma busca imitativa propriamente dita e de fácil acesso. Nos padrões intramuros e extramuros, a diferença reside basicamente no fato do desenvolvimento dos conhecimentos serem realizados dentro ou fora das empresas, respectivamente. No padrão intramuro, as possibilidades técnicas da empresa são determinadas endogenamente. Ao revés, no padrão extramuro, as possibilidades técnicas da empresa são determinados exogenamente (Moreira, M. 1989).

É preciso frisar que embutido nos conceitos de rotina e busca está a questão da trajetória natural. Obviamente, isto não quer dizer que as mudanças técnicas são previsíveis, mas, tratadas como eventos decorrentes de procedimentos heurísticos, caracterizado por um ambiente de incerteza, onde os resultados e esforços inovativos não são conhecidos ex-ante. De acordo com Moreira, M. (1989), "o que o conceito de trajetória natural permite é desenhar uma distribuição da probabilidade, em que eventos que representam uma ruptura radical com a base técnica passada são os menos prováveis". Para Camara (1993, p.23), "rotina não é sinônimo de comportamento repetitivo, estável e permanente. A firma herda as rotinas - via aprendizado ou imitação 
-, mas frente a situações adversas pode alterar os comportamentos convencionais, originando as mutações".

Segundo Canuto (1991, p.314 e 316), os trabalhos de Nelson \& Winter :

"(...) chamaram atenção para a evidência empírica de que, nas aplicações particulares de qualquer tecnologia, existe em maior ou menor grau um conteúdo de conhecimentos tácitos e especificos ('idiossincráticos'). (...) Nas rotinas se embutem as heuristicas e normas de comportamento atinentes ao funcionamento da firma em seus vários âmbitos (produção, formação de preços, comercialização, pesquisas, etc.). incluindo os conhecimentos tácitos e especificos que vão acompanhando a prática repetitiva e seus melhoramentos."

O terceiro conceito fundamental, a seleção, tem a ver com a estrutura institucional (que varia de setor para setor). O ambiente de seleção pode ser non-market (por exemplo: competição entre partidos políticos, universidades, etc) e market (por exemplo: a seleção de mercado dado pelo processo competitivo interfirmas). Além disso, no caso da seleção, constata-se que o uso de insumos e o nível de produto são baseados nas decisões da firma, o que gera o preço final do bem produzido. A rentabilidade vai ser definida pelo preço de mercado. A associação da rentabilidade às regras de investimento e mercado de capitais estabelece as taxas de crescimento ou retração da atividade produtiva (Araújo, 1989).

$\mathrm{Na}$ realidade, os mecanismos de seleção, que podem ser mercantis ou nãomercantis, é que vão determinar a mudança técnica, definindo dessa forma o malogro ou o êxito de uma inovação. Segundo Nelson \& Winter (1977 e 1982), citado por Albuquerque (1996, p.229), "a firma inovadora, buscando a realização de lucros, atua com 'racionalidade limitada', utilizando-se de rotinas e mecanismos de busca, adotando estratégias que serão sancionadas (ou não) por mecanismos de seleção tanto mercantis quanto não-mercantis." Isto vai rebater sobre o processo de busca. Ocorre, então, a interação entre o processo de busca e seleção, onde a dinâmica do processo irá estabelecer padrões de comportamento do mercado e da firma no tempo. Tais colocações podem ser esquematizadas da seguinte forma: 


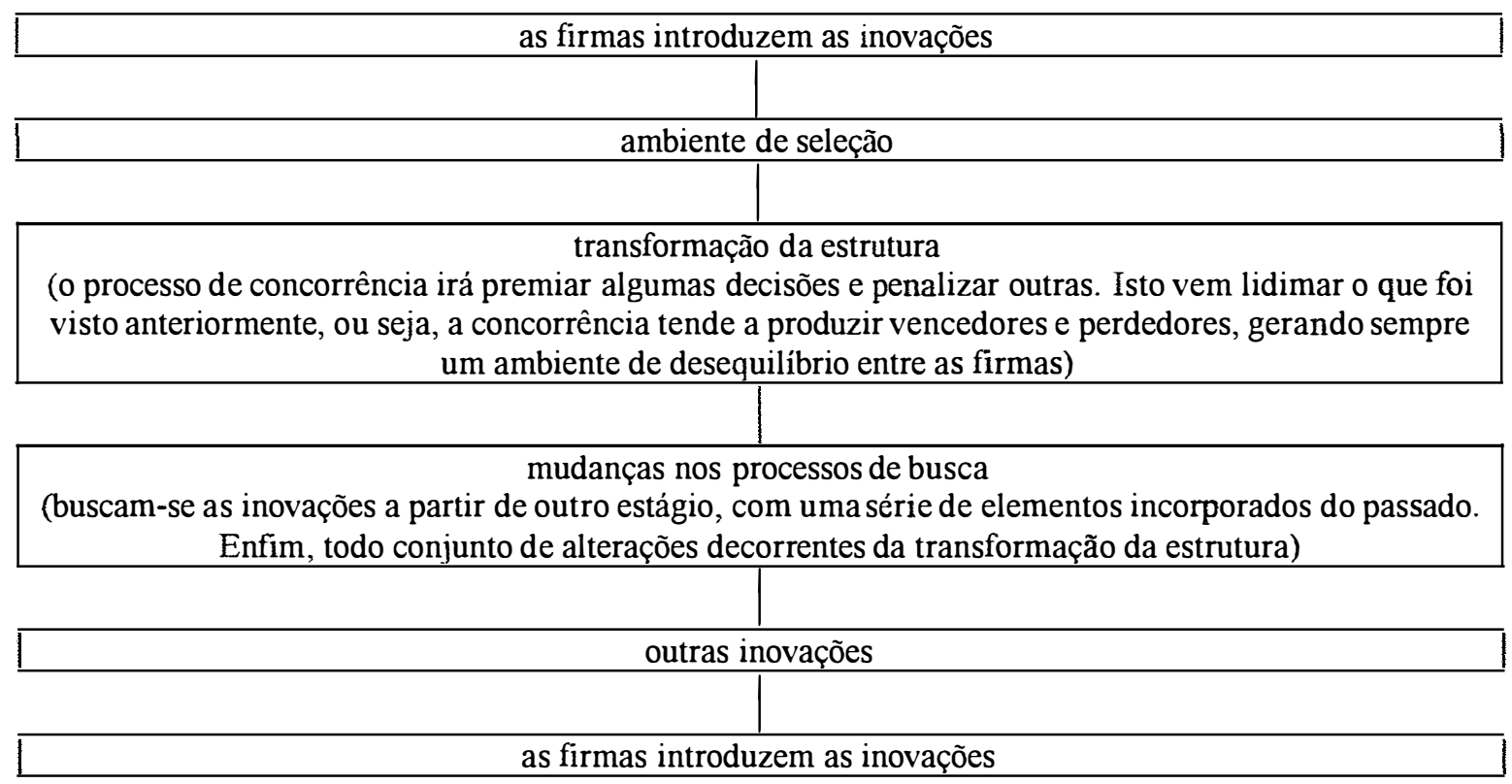

Figura 2 - Esquema simplificado de um padrão de comportamento dinâmico do mercado e da firma.

Aplicando as idéias de Nelson \& Winter no estudo do progresso técnico e estrutura de mercado para o caso da indústria de telequipamentos, Moreira, M. (1989) salienta que a introdução de inovações microeletrônicas alterou substancialmente as condições de demanda e oferta dessa indústria, levando a novos ajustes nas estratégias de competição das firmas. Como resultado desse processo ocorreram transformações na estrutura, com mudanças nas posições relativas das firmas nesse mercado. As firmas buscam agora desenvolver novas tecnologias, compatíveis com o sistema já em funcionamento, para melhor se ajustarem ao novo quadro de mudança tecnológica.

No mecanismo existente entre os processos de busca e seleção ressalta-se a inovação como elemento alimentador e influenciado pelo seu próprio processo. Neste contexto, o caráter dinâmico também é evidenciado, pois a estrutura aparece como resultado de inovações técnicas passadas, isto é, como resultado de um ambiente de seleção. Não obstante, o caráter não determinístico deve ser ressaltado, haja vista o fato das opções de mercado não serem dadas como numa estrutura idealizada pelos neoclássicos, bem como não serem conhecidos os resultados da concorrência. 
Como resultado destes apontamentos de Nelson \& Winter, pode-se observar que a mudança tecnológica é um fenômeno endógeno, produzida pelo próprio processo competitivo. Dessa forma, a contribuição de Nelson \& Winter (1982) é significativa no que respeita à análise dinâmica do processo de inovação tecnológica. Além disso, cabe destacar a ênfase desses autores na questão das rotinas inovadoras, em condições de incerteza keynesiana, como ponto básico para o processo de adoção e seleção de inovações (Salles Filho \& Silveira, 1990). Neste caso, o mercado funciona como uma espécie de fornecedor de feed-backs ao processo de geração, sancionando ou vetando desenvolvimentos prováveis.

Apesar da importante contribuição dada por Nelson \& Winter, existem críticas quanto a essa proposição. Saviotti \& Metcalfe (1991), por exemplo, apontam como questões não resolvidas pelos evolucionistas as seguintes: dificuldades em unir conceitos diferentes em torno de um conjunto unificado e coerente; risco de reducionismo; questão da intencionalidade (a necessidade de explorar uma série de fatos - individual versus coletivo, ambiente independente versus ambiente dependente, etc); e tratamento pouco preditivo. Moreira, M. (1989), por sua vez, ressalta a subestimação de fatores como a decisão de investir, o ritmo de acumulação interna de lucros e a formação de preços, que apresentam-se diluídos no conceito de rotina. Entretanto, esse mesmo autor repara para o fato de que, apesar das críticas realçadas, há que se destacar a possibilidade de incorporação do intervencionismo estatal à análise, dada pela operacionalização do conceito de regime tecnológico (padrão do progresso técnico).

De qualquer modo, o referencial explicativo de Nelson \& Winter ao permitir analisar o comportamento das empresas sob uma perspectiva evolucionista, explicado por meio das idéias de rotina, busca e seleção, denota a importância da contextualização dinâmica para os processos de concorrência. Neste tocante, este instrumental também será útil para a interpretação da evolução diferenciada da agroindústria canavieira do Brasil, posto que as usinas e destilarias apresentam as suas próprias formas de rotina, busca e seleção. 


\subsubsection{DOSI}

Assim como Richard R. Nelson \& Sidney G. Winter, Giovanni Dosi é considerado um dos expoentes da linha tida como evolucionista (Zawislak, 1996). A maior contribuiç̃o de Dosi (1984) está no desenvolvimento de conceitos como a trajetória e paradigma tecnológicos.

Dosi (1984) sugere uma analogia entre tecnologia e ciência, na qual o conceito de paradigma científico elaborado por Kuhn (1995, p.13) - definido como "(..) as realizações científicas universalmente reconhecidas que, durante algum tempo, fornecem problemas e soluções modelare s para uma comunidade de praticantes de uma ciência" - tem como análogo o paradigma tecnológico - definido "(...) como um 'padrão' de solução de problemas tecno-econômicos selecionados, com base em princípios altamente seletos derivados das ciências naturais" (Canuto, 1991, p.318).

Segundo Kupfer (1996, p.356 e 360):

"Na adaptação feita por Dosi ao conceito de Kuhn, um paradigma tecnológico é um pacote de procedimentos que orientam a investigação sobre um problema tecnológico, definindo o contexto, os objetivos a serem alcançados, os recursos a serem utilizados, enfim um padrão de solução de problemas técnico-econômicos selecionados (...). Um paradigma tecnológico é, em sim mesmo, um 'dado' estrutural, fruto de cumulatividades de conhecimentos tecnológicos, de oportunidades inovativas, das características particulares assumidas pelas interações entre aspectos científicos, produtivos e institucionais e, como tal, pode e deve ser tratado em conjunto com os aspectos comportamentais que regem a difusão de inovações."

Ademais, quando Dosi (1984) reporta ao termo tecnologia ele está se referindo a um conjunto de partes do conhecimento, que podem ser práticos e/ou teóricos, e que se aplicam (idéia de sucesso), ou não (idéia de fracasso), a uma determinada atividade. Esse conjunto envolve desde procedimentos, métodos, experiências, know-how, até mecanismos e equipamentos, sendo a busca de novas soluções técnicas em processos e/ou produtos caracteristicamente endógenas e contínuas. Para Salles Filho (1993, p.90), a identificação da tecnologia sob esta ótica "(...) implica a percepção de possíveis 
alternativas atuais e de possiveis desenvolvimentos futuros. Em outras palavras, conforma um conjunto limitado, mas não bem definido, de caminhos a seguir." Isto significa dizer que há dinâmica nessa contextualização referida por Dosi (1984), particularmente a dinâmica do processo de mudança.

A trajetória tecnológica pode ser definida como desdobramentos próprios no interior de um paradigma tecnológico, correspondendo, em geral, às respostas aos diversos trade-offs estabelecidos entre as variáveis tecnológicas (Dosi, 1984). Cabe anotar que, embora de forma mais rara e forte, os paradigmas tecnológicos também podem sofrer modificações. Isto porque, de acordo com Dosi (1984), citado por Albuquerque (1996), as inovações radicais que estão na gênese de um novo paradigma são mais dependentes das novas oportunidades abertas pelas descobertas científicas ou por fortes obstáculos encontrados no desenvolvimento de determinadas trajetórias tecnológicas.

Incorporadas ao conceito de trajetória tecnológica estão algumas importantes características, quais sejam: as trajetórias tecnológicas podem ser mais gerais ou mais circunstanciadas; podem apresentar complementariedades; são parcialmente dependentes de características cumulativas; seus resultados são indefinidos ex-ante - é impossível prever com exatidão o que acontecerá com uma trajetória tecnológica -; a fronteira tecnológica é mutável; e, as tecnologias podem tanto competir entre as novas e velhas tecnologias, como entre as possíveis novas (Salles Filho, 1993).

Pode-se afirmar que a trajetória tecnológica representa a maneira através do qual o paradigma tecnológico evolui, sendo este último o estabelecedor das necessidades a serem atendidas no seu interior. Outrossim, aspectos técnicos, econômicos, sociais e/ou institucionais podem atuar como critérios seletivos sobre tais necessidades. Na opinião de Kupfer (1996), os paradigmas e as trajetórias tecnológicas irão depender tanto de interesses econômicos dos inovadores, como da capacitação tecnológica ${ }^{5}$ acumulada e de

\footnotetext{
${ }^{5}$ A capacitação tecnológica "(...) representa um elemento importante para a competitividade de um setor ou da economia, embora não seja o único" (Furtado, 1994, p.9). "As capacidades tecnológicas compreendem as capacidades de adquirir, assimilar, usar, adaptar, mudar ou criar tecnologia, em três âmbitos: (i) na operação, isto é, no exercicio das atividades correntes de produção, administração $e$ comercialização; (ii) no investimento, ou seja, na execução de novos projetos; e (iii) na inovação, envolvendo a capacidade de buscar internamente inovações maiores de produto e processo e de desenvolver pesquisa básica" (Canuto, 1991, p.315).
} 
variáveis institucionais (colocação esta que permite analisar, por exemplo, a atuação do Estado em um referido setor).

Para Albuquerque (1996), as trajetórias tecnológicas discutidas por Dosi (1984) se confundem com a operação dos processos de busca e seleção definidos por Nelson \& Winter (1982), posto que as firmas buscam determinadas estratégias definidas a partir dos contornos de um paradigma, e num ambiente onde está presente a incerteza. Aliás, segundo Dosi, é a existência dessa incerteza que implica na necessidade de instituições para estabelecer ou estabilizar comportamentos, e de organizar as interações e a coordenação entre os diversos agentes econômicos (Kupfer, 1992).

Percebe-se em Dosi (1984) que o processo seletivo de uma tecnologia ocorre em um ambiente maior, ou seja, no interior de um paradigma tecnológico, onde vários conjuntos de heurísticas e mutações possíveis se comportam dinamicamente. Exemplificando, o desenvolvimento do carro a combustão interna mudou drasticamente os transportes de até então, ou seja, criou-se um novo paradigma tecnológico nessa respectiva área. Os aperfeiçoamentos desse veículo automotor, tais como a injeção eletrônica ou o freio a ar, são considerados, por sua vez, trajetórias tecnológicas. Neste sentido, essas novas oportunidades de produção são frutos de um progressivo processo de aprendizado, a partir da interação de rotinas estabelecidas com experiências adquiridas.

A importância das idéias de Dosi para o presente trabalho está não só na verificação das trajetórias tecnológicas adotadas pelas usinas e destilarias, como na fundamentação da única hipótese a ser testada em nosso estudo: que diz respeito ao fato dos produtores ligados à agroindústria canavieira brasileira estarem inseridos, num primeiro momento, em um paradigma subvencionista; posteriormente, alguns desses produtores passaram a adotar o paradigma tecnológico como forma de definir o que é relevante para uma situação mais concorrencial. Daí uma das razões para a ocorrência da evolução diferenciada verificada na agroindústria canavieira do Brasil. 


\subsubsection{COCHRANE}

Sobre os avancos formulados pelos neoschumpeterianos no que respeita à área agrícola, destaca-se a abordagem de Willard W. Cochrane. Especificamente sobre o treadmill de Cochrane (1979), verifica-se que no meio agrícola existirão produtores (early-birds - pássaros madrugadores) que adotarão novas tecnologias antes dos demais, tendo seus custos reduzidos e um lucro extra; sendo a tecnologia dada neste caso. Os imitadores irão também adotar essa nova tecnologia, haja vista as vantagens decorrentes dessa adoção observadas nos casos dos early-birds. Com o virtual aumento da produção, ocorre a redução do preço do produto agrícola. Há, portanto, uma re-homogeneização líquida, pois nesta situação todos deverão trabalhar numa estrutura de custos semelhantes. Quem não inovar poderá sair do mercado, isto é, o produtor é obrigado a inovar neste mercado concorrencial.

A idéia do treadmill que deve ficar clara é a de que o produtor inova para não sair do mercado, ao mesmo tempo que ele inova para não sair do lugar. A margem de lucro cai concomitante com a queda do preço do produto agrícola.

Os early-birds, por um dado período de tempo, irão investir seus lucros extras preferencialmente em terras, pois sua atividade está dando um relativo retorno. Neste caso, tais ganhos serão usados pelos mais eficientes e "agressivos" produtores para expandir suas operações através da compra de ativos produtivos de produtores menores e menos eficientes. A tendência visualizada é de um processo de concentração da posse de terras. Outrossim, cabe salientar que quem perde agora é também aquele que inovou depois.

O que irá frear o processo acima, segundo Cochrane (1979), é a elevação do preço da terra. Ou seja, nesse processo competitivo o preço da terra é pressionado para cima; logo, o treadmill continua a vigorar e cada vez mais amplia-se a concentração da posse da terra.

Quais são os early-birds na agroindústria canavieira? Quem não inovou, e quem inovou tardiamente na agroindústria canavieira corre o risco de desaparecer do mercado, mesmo diante da presença do Estado na tutela deste setor? Estas perguntas, baseadas nas 
idéias de Cochrane, ao serem respondidas irão contribuir para caracterizar ainda mais a evolução diferenciada da agroindústria canavieira do Brasil.

\subsection{O NEOCORPORATISMO}

Nesta seção são apresentados alguns aspectos centrais da análise neocorporatista, necessários para o entendimento das relações entre o Estado e o setor privado durante a evolução da agroindústria canavieira. Inicialmente, é discutido, sucintamente, a etimologia da palavra neocorporatismo, com o intuito de se evitar possíveis equívocos quanto ao seu sentido. Em seguida, ressaltam-se algumas características básicas da análise neocorporatista, como a "orquestração" de interesses, o surgimento de conflitos e rupturas, e o "chamamento" do Estado. Por fim, especificam-se os diversos interesses verificados no interior da análise neocorporatista, como os interesses privados e públicos - este último subdividido em interesses de Estado, do governo (do regime) e de seus funcionários.

O termo corporatismo deriva das associações profissionais denominadas corporações de oficio, presentes como unidades econômicas na Europa durante a Idade Média (Franco Júnior \& Chacon, 1986; e Belik, 1992). Na lexicologia nacional não se verifica a existência do termo corporatismo, existindo, por outro lado, o termo corporativismo - cujo significado é "a doutrina que prega a reunião de classes produtoras em corporações, sob a fiscalização do Estado". Outrossim, algumas experiências históricas da Itália (fascismo), da Espanha (franquismo) e de Portugal (salazarismo) denotam à palavra corporativismo características ideológicas de regimes autoritários e conservadores (Soto, 1993).

O que é preciso distinguir preliminarmente é que o neologismo neocorporatismo (com prefixo neo, sugerindo o novo) aparece na literatura econômica como referindo-se "(...) às ações e práticas verificadas que se referem à representação e à forma de fazer política por parte dos grupos de interesse. O neocorporatismo representa um arranjo institucional, ligando interesses organizados com as estruturas de decisão do Estado" (Belik, 1992, p.9). ${ }^{6}$ O neocorporatismo "é, na verdade, uma interação estratégica (jogo

\footnotetext{
${ }^{6}$ Exposições mais exaustivas sobre o termo neocorporatismo podem ser encontradas em Belik (1992), Soto (1993) e Saes (1995). Esta terceira autora ainda analisa as teorias da regulamentação por interesse
} 
de contrários) que pode produzir uma variedade de resultados ou arranjos dependendo das condições históricas particulares em que estas organizações foram geradas e se desenvolvem" (Saes, 1995, p.19) '.

No neocorporatismo o princípio de "orquestração" de interesses fundamenta-se como o núcleo da ordem corporativa-associativa, onde a satisfação dos interesses de seus agentes seria alcançada pelo ajuste mútuo e pelas interações repetidas (Saes, 1995). Esses interesses, vale lembrar, não são isentos de base econômica, ao revés, são habitualmente revestidos de propostas econômicas concretas (Belik, 1992). Ademais, de acordo com a amplitude dos interesses envolvidos, pode-se considerar três níveis distintos de corporatismo: o macro-corporatismo, meso-corporatismo e micro-corporatismo. No primeiro caso, o nível de agregação toma a associação de interesses como uma forma de regulação da sociedade em escala nacional, estando, dessa forma, acima dos interesses setoriais e baseados sobremaneira em acordos tripartites de longo alcance. No mesocorporatismo as associações de interesses, baseadas em movimentos interdependentes, estão organizadas por categorias setoriais. É neste caso que se enquadram as associações empresariais, as agências governamentais e outros grupos de interesses e organizações que se articulam e implementam políticas setoriais. Por fim, tem-se o micro-corporatismo, onde o nível de acertos diretos entre empresas e Estado ocorre sem que haja necessariamente uma organização intermediando os interesses (Belik, 1992).

Para a implementação de pactos e compromissos estáveis dentro deste contexto de neocorporatismo, torna-se necessário que os agentes componentes dessa ordem possuam um certo grau de simetria, não só de interesses, como de recursos, capacitações e comportamentos (Saes, 1995). Do contrário, o processo de tomada de decisão numa ordem corporatista torna-se vulnerável a conflitos e rupturas, posto a existência de incertezas quanto ao futuro dos compromissos. Como esta simetria não é facilmente obtida no mundo capitalista, e sendo comum cada lado objetivar resultados particulares durante os processos de ajustes de interesses, ocorre amiúde a necessidade de

público (que enfatiza a intervenção com o escopo de corrigir as falhas de mercado) e por grupos de interesse (que enfatiza a intervenção como resultado da demanda de grupos de poder que almejam políticas específicas), ambas do mainstream da literatura neoclássica.

${ }^{7}$ Essa autora usa em seu trabalho o neologismo neocorporativismo; que, neste caso, tem o mesmo significado do termo neocorporatista. No presente estudo utiliza-se apenas este segundo termo, pois procura-se desvincular da análise neocorporatista as amarras históricos-ideológicas de regimes autoritários. 
intermediação do Estado. Neste caso, o intercâmbio político neocorporatista envolve um processo de duplo sentido: "num deles, a representação dos interesses privados procura influenciar as autoridades do governo com o propósito de provocar decisões que a favoreçam; no sentido inverso, as autoridades governamentais procuram influenciar na articulação dos interesses privados" (Soto, 1993, p.6-7). Neste ponto verifica-se uma coincidência (casual) com a abordagem de Dosi (1984), pois o "chamamento" de instituições externas à firma, como o Estado, serve como mecanismo de organização e coordenação de interesses entre os agentes econômicos, de forma a minimizar a existência de incertezas.

A intermediação estatal vem corroborar o fato do neocorporatismo representar uma forma de arranjo institucional - conforme salientado por Belik (1992). Por outro lado, capacita o próprio Estado, mediante esta interação, a implementar políticas setoriais com maior aval (Saes, 1995). Neste contexto, a entrada do Estado para facilitar o jogo de interesses privados, no âmbito do neocorporatismo, se justifica por duas razões claras: primeiro, pelos relativamente baixos custos decorrentes dessa intermediação; segundo, porque o próprio Estado estaria ampliando a sua área de atuação, modificando, de certa maneira, o jogo de interesses privado para privado-público.

Podem ocorrer casos onde esse tipo de "chamamento" ao Estado não se verifica, pois o mesmo já é parte componente da ordem corporativa-associativa, com seus próprios interesses em jogo.

Um acontecimento que eventualmente pode ocorrer é o que Wilson \& Butler (1985) rotulam de falso corporatismo, no qual o Estado assume a direção dos processos de decisões, tornando-se o deliberador-mor dentre os agentes de uma determinada associação. Numa outra situação, ou seja, diante das incertezas e inseguranças inerentes aos processos de tomada de decisão numa ordem neocorporatista, aumenta-se o risco do Estado perder a sua autonomia. O que obstaculiza essa autoridade (domínio) sobre o Estado, segundo Streeck \& Schmitter (1985), são as disputas entre os diversos grupos de interesses existentes dentro do aparelho estatal.

$\mathrm{Na}$ análise neocorporatista existem dois grandes blocos de interesses: o privado oriundo de segmentos da sociedade cujo domínio é particular -; e o público - pertencente e/ou destinado à coletividade. Dentro do interesse público ainda se verificam os interesses 
de Estado, do governo (do regime) e dos funcionários. Schmitter (1985), citado por Belik (1992, p.9), define estes interesses da seguinte forma:

"Os interesses do governo como aqueles que possam assegurar a reprodução do modelo existente de assignação de cargos públicos e controle sobre a máquina. Os interesses de funcionários têm aspectos estruturais ligados a necessidade de auto perpetuação. Os interesses de Estado se confundem, por sua vez, com os dos funcionários governantes e grupos que giram em torno do Estado. Ainda assim, o Estado baseia os seus interesses no engrandecimento nacional e na sua posição frente às ameaças externas."

A análise neocorporatista apresenta-se como de grande valia para compreender o caráter funcional da relação entre grupos de interesses e o Estado, sobretudo para verificar como se comporta a intervenção estatal a partir dessa interação. Torna-se necessário avançar também no entendimento dos arranjos institucionais, derivados dos interesses organizados com as estruturas de decisão situados dentro do aparelho do Estado. Dessa forma, este procedimento contribui para elucidar os processos de formulação e implementação de políticas públicas.

Cabe anotar que Belik (1992), por exemplo, utilizou-se da análise neocorporatista para verificar a agroindústria processadora e a política econômica, destacando em seu estudo três setores característicos da economia brasileira: óleos vegetais, sucroalcooleiro, celulose e papel. O presente trabalho, diferentemente de Belik (1992), recorre à análise neocorporatista, juntamente com a neoschumpeteriana, para procurar mostrar como ocorreu a evolução diferenciada na agroindústria canavieira. De fato, a "orquestração" de interesses, ferramenta-chave da análise neocorporatista, colaborará para explicar porque o PROÁLCOOL foi bem sucedido diante das outras alternativas energéticas em suas duas primeiras fases (1975-1979 e 1980-1985), para decair e entrar em crise já numa terceira fase (1986-1995). A análise neoschumpeteriana, por sua vez, contribuirá para observar fatores como: qual foi o "gargalo" propiciador de inovações na agroindústria canavieira? $\mathrm{Ou}$, quais foram as estratégias tecnológicas adotadas pelas usinas e destilarias que se distanciaram das demais? Por conseguinte, acredita-se que a combinação desses dois instrumentais analíticos possibilitirá uma melhor avaliação de como se deu a evolução diferenciada na agroindústria canavieira do Brasil. 
Neste sentido, mais especificamente no capítulo 5 - ou seja, após breve exposição de uma visão histórica fundamental para o entendimento de certos aspectos da atual conjuntura da agroindústria canavieira brasileira (capítulo 3) e de um panorama estrutural do que de fato existe no eixo agroindústria-mercado da economia canavieira (capítulo 4) - observar-se-ão aspectos importantes da análise da agroindústria canavieira à luz do referencial teórico ressaltado no capítulo 2. Destarte, numa visão prospectiva ao presente capítulo, podem-se observar interpretações da evolução dessa agroindústria a partir dos instrumentais neocorporatista e neoschumpeteriano. É o caso de se considerar que as crises do petróleo (de 1975 e 1979) geraram um "gargalo" no processo produtivo, propiciando um ambiente favorável ao surgimento de alternativas energéticas, enquanto a crise da agroindústria canavieira (da primeira metade da década de 70) favoreceu a "orquestração" de interesses que levou o País a optar pelo PROÁLCOOL - cuja fase de expansão irá de 1975 a 1985. Outrossim, de 1986 a 1995, ocorreu um período de desaceleração do crescimento e crise do PROÁlCOOL. O "gargalo", oriundo das crises do petróleo desapareceu, anulando dessa forma a justificativa diante da população brasileira para manter o corporatismo em torno do PROÁLCOOL. A crise desse Programa contribuiu para avultar a diferenciação em termos produtivos existente na agroindústria canavieira, onde algumas empresas menos preparadas em termos de capacitação tecnológica encerraram suas atividades ou foram incorporadas pelas mais dinâmicas (que adotaram o paradigma tecnológico). 


\section{A AGROINDÚSTRIA CANAVIEIRA BRASILEIRA DE SUA ORIGEM ATÉ 1974}

Objetivando um maior entendimento das vicissitudes ocorridas na agroindústria canavieira entre 1975 e 1995, faz-se necessário primeiramente relatar os principais aspectos caracterizadores da evolução da agroindústria canavieira brasileira desde sua origem até 1974, intento do presente capítulo.

Foi com o objetivo de efetivar a colonização e defesa das terras brasileiras, então ameaçadas por corsários franceses, ingleses e espanhóis, que Portugal incentivou o desenvolvimento da cultura da cana-de-açúcar no Brasil-Colônia nos primórdios do século XVI. Cabe destacar que nessa época o açúcar era um produto de importante inserção no mercado mundial, apreciado sobretudo na Europa (Shikida, 1992). Implícito neste objetivo de ocupação e defesa das terras brasileiras - via desenvolvimento da cultura canavieira - figurava a mentalidade mercantilista dessa Colônia vir a produzir divisas para a Coroa portuguesa.

De fato, com condições edafo-climáticas relativamente favoráveis ao cultivo da cana-de-açúcar, adicionadas a uma série de medidas de incentivo à expansão dessa cultura, pôde o açúcar tornar o principal produto local. O prestígio da cana-de-açúcar foi de tal valor para a economia colonial brasileira a ponto de caracterizar, entre 1530 a 1650, o ciclo do açúcar, período este fundamentado basicamente nas exportações de açúcar (Furtado, 1974). Nessa fase, o cultivo da cana-de-açúcar expandiu-se em faixas litorâneas, ocupando terras das capitanias de Pernambuco, Bahia de Todos os Santos, São Tomé (Rio de Janeiro) e São Vicente (São Paulo). Os elementos mormente caracterizadores dessa exploração agrícola foram: o latifúndio - a grande propriedade rural onde era cultivada a cana-de-açúcar, e onde estava instalado o Engenho (construção ainda primitiva na qual se processava a fabricação do açúcar) -; o trabalho escravo; e a monocultura. Todo o apoio e regulamentação dessa atividade econômica ficavam à mercê 
da Metrópole portuguesa, que não só doou aos fidalgos portugueses as primeiras frações de terras brasileiras - as capitanias hereditárias -, como estimulou o tráfico de escravos para o Brasil.

Para Albuquerque \& Nicol (1987), a proibição de atividades que concorressem com a produção de açúcar e a concessão de poderes monopolísticos aos grandes plantadores de cana-de-açúcar retratam parte dessa orientação intervencionista. Conforme Lima (1992, p.12), "historicamente, a economia açucareira no Brasil foi marcada pela intervenção do Estado, que evoluiu do puro e simples estabelecimento de regras básicas para o funcionamento dos primeiros engenhos de açúcar no século XVI, até a intervenção mais direta (...)."

As primeiras dificuldades - de natureza concorrencial - para a economia açucareira brasileira ocorreram a partir do desenvolvimento da produção açucareira nas Antilhas, que se seguiu à expulsão dos holandeses do Brasil, entre 1630 e 1650 (Von Lippmann, 1941). Logo, a hegemonia da distribuição do açúcar gradativamente foi sendo diluída via recrudescimento na competição pelos mercados açucareiros europeus. Posteriormente, além da concorrência do açúcar antilhano, o açúcar brasileiro passou a competir também com o açúcar de beterraba, que começou a ganhar destaque no mercado europeu pelos idos de 1830 (Lima, 1992).

Nessa época vale citar, segundo Dé Carli (1936), que a maioria dos estabelecimentos produtores de açúcar do Brasil não dispunham de maquinismos modernos e nem de técnicas mais apuradas.

Diante desse panorama dificil vivenciado pela economia açucareira, "a antiquada indústria brasileira do açúcar começou a ser questionada, e passou a considerar seriamente a introdução de equipamento moderno e a divisão de trabalho entre o cultivo da cana e a fabricação do açúcar" como tentativas para superação dessa crise (Suzigan, 1986, p.203). Nesse sentido, na tentativa de ajustar a indústria brasileira do açúcar às tendências observadas nos países de vanguarda nesse tipo de produção, o Governo Imperial procurou estimular a modernização dessa atividade produtiva via medidas de amparo aos chamados engenhos centrais, isto nos idos de 1875 (Lima, 1992). Segundo Suzigan (1986, p.203-204): 


\begin{abstract}
"Os engenhos centrais, equipados com máquinas modernas, se especializariam no estágio industrial do processo de produção de açúcar, comprando cana dos produtores, os quais, por sua vez, se concentrariam apenas no cultivo da cana. Acreditava-se que essa divisão do trabalho aliviaria os plantadores de investimentos de capital em usinas e, assim, eles poderiam empregar seus recursos na melhoria dos métodos de cultivo; também se acreditava que essa divisão de tarefas ajudaria o plantador na transição do trabalho escravo para o trabalho livre. Ao mesmo tempo, os engenhos centrais, não tendo que investir em plantio, concentrariam seus recursos em usinas mais modernas e eficientes. A maquinaria moderna permitiria aumentar a taxa de extração de açúcar de cana vis-à-vis o de beterraba. Acreditava-se também que os salários cairiam devido à redução da mão-de-obra resultante da modernização. 'Os resultados seriam cana mais barata e açúcar mais barato e mais competitivo'."
\end{abstract}

Novamente observa-se o Estado atuando de forma a estimular o desenvolvimento da agroindústria canavieira. Dessa vez, o Governo Imperial contribuiu para a fundação de alguns engenhos centrais através de uma reserva para amparo à indústria e garantia de juros aos capitais que nela se invertessem (Dé Carli, 1936), assumindo, assim, parcela do risco deste empreendimento. O maior beneficiado com a concessão de recursos para esta finalidade foram os produtores de Pernambuco, à época (1890) o maior centro açucareiro do Brasil. Seguia-lhe a Bahia, Rio de Janeiro, Alagoas e Sergipe, que, juntos, concentraram $70 \%$ do capital garantido para montagens de engenhos centrais (Dé Carli, 1943).

Essa tentativa de inovação na agroindústria canavieira brasileira, travestida na separação entre as atividades agrícola e industrial e na introdução de maquinismos mais modernos ${ }^{8}$, colidiu com a estrutura de poder e de dominação sócio-econômica-política que sempre caracterizou a produção açucareira, assentada particularmente na concentração e no monopólio da propriedade fundiária (Ramos, 1991). Ademais, o fornecimento inconstante de matéria-prima acabou por contribuir para o malogro da era

\footnotetext{
${ }^{8}$ Tradicionalmente houve na indústria açucareira uma lenta evolução em termos de desenvolvimento tecnológico. Apenas no final do século passado houve a introdução do moinho a vapor no processo de produção do açúcar, representando uma das maiores e mais significativas mudanças tecnológicas neste segmento produtivo (Lima \& Melo, 1989).
} 
dos engenhos centrais no Brasil, em fins do século XIX e princípio do século XX (Costa Filho, 1963).

A passagem para a fase das usinas - unidades produtoras sucessoras aos engenhos centrais - foi, em certo sentido, uma vitória da produção integrada (Ramos, 1991). A maior independência com relação aos fornecedores, com maior controle tanto sobre o suprimento como em relação aos preços, apresentou-se como a característica básica da fase das usinas (Suzigan, 1986). Para Lima (1992), a usina provocou uma mudança no ciclo econômico da agroindústria canavieira, posto que se verificou uma acentuada melhoria da matéria-prima bem como um maior rendimento industrial, decorrentes do melhor uso dos processos de cultivo, seleção de mudas, técnicas de irrigação, etc, frutos diretos da utilização de um maior volume de recursos que só a usina poderia efetuar.

Contudo, tais melhorias derivadas da fase das usinas não foram suficientes para fornecer à agroindústria canavieira nacional condições necessárias para a superação de fatores adversos do mercado internacional do açúcar, como a forte concorrência do açúcar derivado da própria cana - oriundos da produção antilhana - e também da beterraba - oriundos da produção européia que, vale ressaltar, era protegida e incentivada pelos governos europeus, notadamente alemão e francês (Ramos \& Belik, 1989).

Com a retração do mercado externo do açúcar em final da década de 20 e início da década de 30, pari passu ao elevado desenvolvimento da cana-de-açúcar averiguado em São Paulo após a crise do café, a agroindústria canavieira nordestina foi atingida por dois duros golpes. De acordo com Ramos \& Belik (1989) e Ramos (1991), devido às condições edafo-climáticas relativamente favoráveis ao cultivo da cana-de-açúcar, e dada a maior proximidade do Nordeste em relação ao mercado europeu, o açúcar nordestino sempre teve destaque na produção e exportação brasileira. Desse modo, com a redução das transações no mercado externo açucareiro, o maior prejudicado foi o produtor do Nordeste. Por outro lado, estando a economia açucareira confinada parcialmente aos limites do mercado interno de consumo, e estando os produtores centro-sulistas, especialmente os paulistas, em ascensão, a produção açucareira nordestina teve que competir também com a produção localizada na região Centro-Sul. Esta produção, por sua vez, era beneficiada pela maior proximidade do mercado e pela não coincidência da sua época de safra com a do Nordeste (Lima, 1992) - veja o apêndice A para breves comentários sobre o ciclo da lavoura canavieira e o seu calendário agrícola. Estes fatores, 
adicionados aos saltos tecnológicos dados pela agroindústria canavieira paulista sobretudo para substituir variedades de cana suscetíveis às doenças (Ramos \& Belik, 1989) - e à própria lentidão das mudanças nos padrões tecnológicos verificados na agroindústria canavieira nordestina (Lima \& Silva, 1995), contribuíram para agravar a crise na economia canavieira do Nordeste nos anos 30.

Diante desse agravamento na crise da economia canavieira do Nordeste, teve início em 1931 uma tímida intervenção por parte do Estado para controle da oferta de açúcar, por meio de planos de defesa da produção de açúcar, aguardente e álcool, atendendo, assim, a uma solicitação dos usineiros, principalmente daqueles situados no Nordeste (Ramos \& Belik, 1989; e Lima, 1992). Diante da persistência de problemas como o excesso de produção e queda dos preços do açúcar, foram reinvidicadas novas formas de intervenção estatal no setor ainda em 1932-33, destacando-se as quotas de produção, o que significaria garantir aos produtores de cada região um mercado cativo. Neste ponto vale realçar a histórica importância da "orquestração" de interesses no sentido de manter à tona a agroindústria canavieira do Nordeste. Para Lima (1988a, 1988b), o capital açucareiro nordestino tem demonstrado uma invulgar capacidade de organização interna, a ponto de consolidar um forte grupo de pressão capaz de garantir o apoio do Estado, o que lhe tem rendido um tratamento diferenciado.

Para Szmrecsányi (1979, p.163), "o planejamento, entendido como processo de intervenção racional do Estado nas atividades econômicas, foi institucionalizado na agroindústria canavieira do Brasil de forma gradual - isto é, por aproximações sucessivas - e a pedido dos próprios produtores do subsetor." Neste sentido, o surgimento do Instituto do Açúcar e do Álcool (IAA) foi reflexo das reinvidicações dos senhores de engenhos, de usinas e dos fornecedores, de terem um órgão controlador da economia canavieira (Azevedo, 1958). Tornava-se, pois, necessária a presença de um intermediador dos interesses dessas classes referidas (além das figuras dos intermediários e consumidores).

Deve-se notar, entretanto, que este "chamamento" ao Estado ocorreu principalmente porque os agentes componentes da agroindústria canavieira não possuíam um certo grau de simetria, não só de interesses, como de recursos, capacitações e comportamentos (semelhantemente ao que fôra retratado no neocorporatismo). Além disso, esta assimetria se verificava tanto entre os produtores do Norte/Nordeste e Centro- 
Sul, como dentro dessas próprias regiões - por exemplo, entre as classes dos usineiros e a classe dos fornecedores de cana. Neste sentido, a intervenção feita pelo IAA continha uma certa finalidade, qual seja: a minimização de incertezas inerentes ao segmento produtivo em questão (garantia de mercado, maiores facilidades para a obtenção de crédito, armazenagem, etc). Vale lembrar, segundo Dosi (1984), que a existência de incerteza favorece a entrada de uma instituição para organizar as interações e a coordenação entre os diversos agentes econômicos desse ambiente econômico.

De fato, a criação do IAA, através do Decreto o 22.789, de 1o de junho de 1933, teve como objetivo defender as empresas açucareiras e alcooleiras nacionais mediante a utilização de uma série de mecanismos (controle de preços e da comercialização, estabelecimentos de quotas de produção, etc) capazes de garantir, dentre outras coisas, o equilíbrio interno entre as safras anuais de cana-de-açúcar e o consumo dos seus principais produtos (Lima, 1992). Segundo Queda (1972), com o IAA a intervenção estatal na agroindústria canavieira se fez presente da produção de matéria-prima até sua conseqüente fabricação, estendendo-se à distribuição, consumo e exportação do produto final. Ademais, as relações entre fornecedores e usineiros e destes com os seus lavradores também foram disciplinadas pelo IAA. Estabelecer políticas de equilíbrio entre a produção e o consumo - via, principalmente, controle de preços e determinação de quotas de produção e comercialização -, financiar safras a usineiros e fornecedores, e propor normas para a assistência social aos trabalhadores deste setor, constituíam-se em outras formas de regulamentação da atividade canavieira no País. Com a criação do IAA, teve início, segundo análise da atuação do Estado na agroindústria canavieira feita por Queda (1972), a fase econômica da agroindústria canavieira.

Esse intervencionismo estatal na agroindústria canavieira não foi de todo homogêneo, apresentando para cada circunstância e região uma especificidade própria, sendo isto uma característica notória da forma de atuar do IAA (Shikida, 1992). É o que atesta Queda (1972, p.15) ao expor que:

"(...) através do estabelecimento de limites de produção entre o Nordeste e a região Centro-Sul, visava-se resguardar a unidade política nacional, impedindo assim a destruição da economia nordestina então ameaçada pela expansão paulista. Por essa razão é que a posição assumida pelo Estado teve que 
variar, quanto à sua intensidade e quanto aos aspectos, de uma região para outra."

Outra forma distinta de intervencionismo estatal entre o Centro-Sul e NorteNordeste se verificou com o surgimento do Estatuto da Lavoura Canavieira (ELC) em 1941. Conforme Queda (1972), guardadas as devidas proporções, o ELC representou para a agroindústria canavieira (parte industrial) o mesmo que a Consolidação das Leis do Trabalho (CLT) representou para o proletariado urbano. Não obstante, para o NorteNordeste - e também fração dos campos fluminenses - este Estatuto procurou manter os fornecedores de cana ante a expansão das usinas. Tornava mister conciliar o atraso tecnológico e a conseqüente baixa produtividade dessa agroindústria canavieira com a modernidade de alguns usineiros. Ademais, um dos objetivos do ELC consistia em "criar" a figura do fornecedor (Shikida, 1992). Ressalta-se que com o surgimento do Estatuto da Lavoura Canavieira teve início, segundo análise da atuação do Estado na agroindústria canavieira feita por Queda (1972), a fase jurídico-institucional-assistencial dessa agroindústria.

Cumpre registrar que várias alterações legislativas foram efetuadas pelo IAA após a promulgação do ELC (1941) até meados da década de 60. Nesse intermédio, o CentroSul se consolidou hegemonicamente na agroindústria canavieira nacional, com proeminência para São Paulo. Entre 1965/69 a 1971 ocorreu o que Queda (1972) denominou de fase tecnológica, onde, em nome de uma maior competitividade setorial, promoveram-se políticas de incentivo às fusões e incorporações de usinas, melhorias nas áreas de pesquisa agronômica e industrial da agroindústria canavieira do País, culminando com a criação do Programa Nacional de Melhoramento da Cana-de-Açúcar PLANALSUCAR - em 1966 (mas que só começou a funcionar em 1971). Diga-se a propósito, é a partir de 1971 que se registra a instituição da política de subsídio de equalização de custo, onde a diferença de custo entre os produtores do Norte/Nordeste e Centro-Sul seria coberto por um subsídio pago pelo governo (Lima, 1992). Este mecanismo de equalização de custos ampliava o paradigma subvencionista como modelo de sobrevivência, em favor principalmente dos produtores nordestinos - que ainda seriam beneficiados com a alta dos preços internacionais do açúcar no triênio 1973-1974-1975, favorecendo, assim, suas exportações. 
Pode-se aferir que, historicamente, a agroindústria canavieira do Brasil fôra objeto de intervencionismo governamental, variando apenas de grau conforme as circunstâncias e interesses de cada época. Contudo, foi efetivamente a partir da criação do IAA, na década de 30 , que o produtor da agroindústria canavieira passou a estar sujeito a uma série de arranjos institucionais que ligavam os interesses organizados do setor - sobretudo os do Nordeste - com as estruturas de decisão do Estado. Esse arranjo institucional, por um lado, proporcionava ao produtor, seja de que região fosse, um certo paradigma subvencionista como modelo de sobrevivência. Quer dizer, com mecanismos de regulação da atividade produtiva que iam desde o estabelecimento de quotas de produção (significando reserva de mercado), fixação de preços para a cana-de-açúcar, açúcar e álcool (significando uma certa garantia de margens mínimas de lucro), até a concessão de subsídios (significando um estímulo direto à atividade), o produtor da agroindústria canavieira não precisava, necessariamente, preocupar-se com alternativas tecnológicas que pudessem reduzir custos e proporcionar maior competitividade setorial, posto que sua permanência no setor estaria garantida minimamente pelos expedientes ora citados. Com tal panorama é incontroverso que muitos dos produtores da agroindústria canavieira se habituaram com este modelo de sobrevivência. Para Caron (1996, p. 14):

"A intervenção do Estado, através de subsídios ao consumo e equalização de rendimentos entre produtores, também teve $e$ tem efeitos no sentido de desfavorecer o surgimento de um ambiente competitivo, fazendo com que novos processos sejam postergados ou descartados e levando os empresários a se aterem apenas à produção de açúcar e álcool."

Estando a remuneração garantida, o uso de práticas rotineiras pôde ser continuamente reproduzida e os processos de busca e seleção passaram a ser condicionados por este paradigma subvencionista. Neste tocante, o Estado contribuiu para interferir, dessa vez com maior intensidade, no padrão de busca das empresas da agroindústria canavieira, exercendo influência sobre todos os elementos do mercado interno, sobre as exportações e, posteriormente, sobre as pesquisas agronômicas voltadas para o setor, ampliando enormemente a sua área de atuação.

Deve-se ressaltar, conforme observado, que mesmo antes de 1975 a agroindústria canavieira no Brasil já apresentava diferenciação entre seus estados produtores. Posteriormente, entre 1975 e 1995, fatores como a fragmentação do setor açucareiro 
mundial e o PROÁLCOOL irão proporcionar à agroindústria canavieira do País uma dinâmica própria, assuntos estes a serem pormenorizados no capítulo 5 . O próximo capítulo (4) procura traçar um perfil da organização da agroindústria canavieira, da geração de tecnologia e dos seus principais produtos e subprodutos. 


\section{ASPECTOS DA ORGANIZAÇÃO, GERAÇÃO DE TECNOLOGIA E PRINCIPAIS PRODUTOS E SUBPRODUTOS DA AGROINDÚSTRIA CANAVIEIRA DO BRASIL}

Nesta seção é feita, à guisa de uma revisão bibliográfica, uma breve análise da organização da agroindústria canavieira brasileira, situando a importância das cooperativas e do Estado dentro dessa agroindústria - cujas características, é bom ressaltar, são próximas a de um oligopólio competitivo (seção 4.1). Na seqüência é feito um levantamento sobre os centros de pesquisa, evidenciando o cenário de geração de tecnologia neste setor, e os principais produtos e subprodutos da agroindústria canavieira brasileira (seção 4.2).

\subsection{A ORGANIZAÇÃO DA A GROINDÚSTRIA CANAVIEIRA}

Inicialmente, faz-se necessário retomar o significado do termo agroindústria ora empregado, cujo sentido neste estudo é de um referencial analítico capaz de permitir a análise dos elementos fundamentais para a interpretação dinâmica do desenvolvimento capitalista - neste caso para o segmento produtivo em questão. ${ }^{9}$ Uma simplificação da perspectiva dinâmica do eixo agroindústria-mercado canavieiro do Brasil retrata as atividades produtivas e comerciais que envolvem o produtor de insumos; a produção de cana-de-açúcar, sendo esta feita por fornecedores e/ou proprietários de usinas e

\footnotetext{
${ }^{9}$ Este trabalho não utiliza conceitos como complexo agroindustrial (CAI) - conjunto formado pelos setores produtores de insumos e maquinarias agrícolas, de transformação industrial dos produtos agropecuários e de distribuição, de comercialização e financiamento nas diversas fases do circuito agroindustrial (Sorj, 1980) - e cadeia agroindustrial - definida como a seqüência de operações interdependentes que tem como intento produzir, modificar e distribuir um produto. Isto devido ao fato desses conceitos recorrerem a expedientes estáticos, não captando as transformações da base técnica, posto que essas noções não consideram a dinâmica como unidade de análise relevante (Possas, 1991). Sobre este modo de observação, três ensaios sugerem um conjunto de elementos conceituais, como marco de referência teórico alternativo, usado para o tratamento da dinâmica agroindustrial e de suas transformações. Sobre isto ver: Possas (1991), Salles Filho \& Silveira (1991) e Belik (1992).
} 
destilarias, podendo advir tanto de empresas individuais como de cooperativas; e a transformação industrial, geradora de uma gama de produtos e subprodutos que, conforme sua especificação, destinam-se ao mercado interno e/ou externo, e que também podem advir tanto de empresas individuais como de cooperativas. Os agentes, em parte condicionadores dos movimentos no interior desse eixo, são representados pela figura das empresas individuais, cooperativas e Estado (vide figura 3). O subconjunto composto pelo segmento agrícola e o segmento industrial processador da cana-de-açúcar é conhecido na literatura como agroindústria canavieira.

Segundo dados das safras 87/88 e 88/89 (ANUÁRIO ESTATÍSTICO DO BRASIL, 1990), em média, cerca de 35,9\% da cana moída nas usinas adveio de fornecedores, enquanto $64,1 \%$ foram produzidas pelos proprietários. Na safra 1994/95, $38,3 \%$ da cana moída nas usinas adveio de fornecedores e $61,7 \%$ foram produzidas pelos proprietários - dados reunidos por Carvalho (1996).

Evidencia-se na agroindústria canavieira uma relativa atuação das cooperativas. Segundo COPERSUCAR (1989a, p.14), "no Brasil (...) o açúcar é fabricado por usinas localizadas principalmente em São Paulo, Pernambuco, Alagoas e Rio de Janeiro. Das mais de 200 usinas situadas nesses Estados (...) cerca de 80\% fazem parte de cooperativas." Atualmente, a maior cooperativa em atividade no setor sucroalcooleiro é a própria COPERSUCAR.

Embora o controle governamental sobre a agroindústria canavieira já fizesse presente antes da criação do IAA, o Estado, de 1933 (ano de criação do IAA) até o ano de 1990 (onde se extinguiu o IAA), desempenhou diversas formas de intervencão direta no setor, praticamente fomentando, dirigindo e controlando as produções de açúcar e do álcool em todo o País. Segundo Moreira, E. (1989, p.107), um dos papéis do Estado na agroindústria canavieira, a partir da edição do PROÁLCOOL, foi o de "criar" mercado:

"O Estado, que antes do PNA baseava sua intervenção no controle da oferta e na neutralização das flutuações dos preços do açúcar no mercado internacional, vai ampliar sua presença através da 'criação' da demanda para o álcool combustivel, seja fixando percentuais de mistura à gasolina, seja mantendo os diferenciais de preços entre os dois combustiveis". 


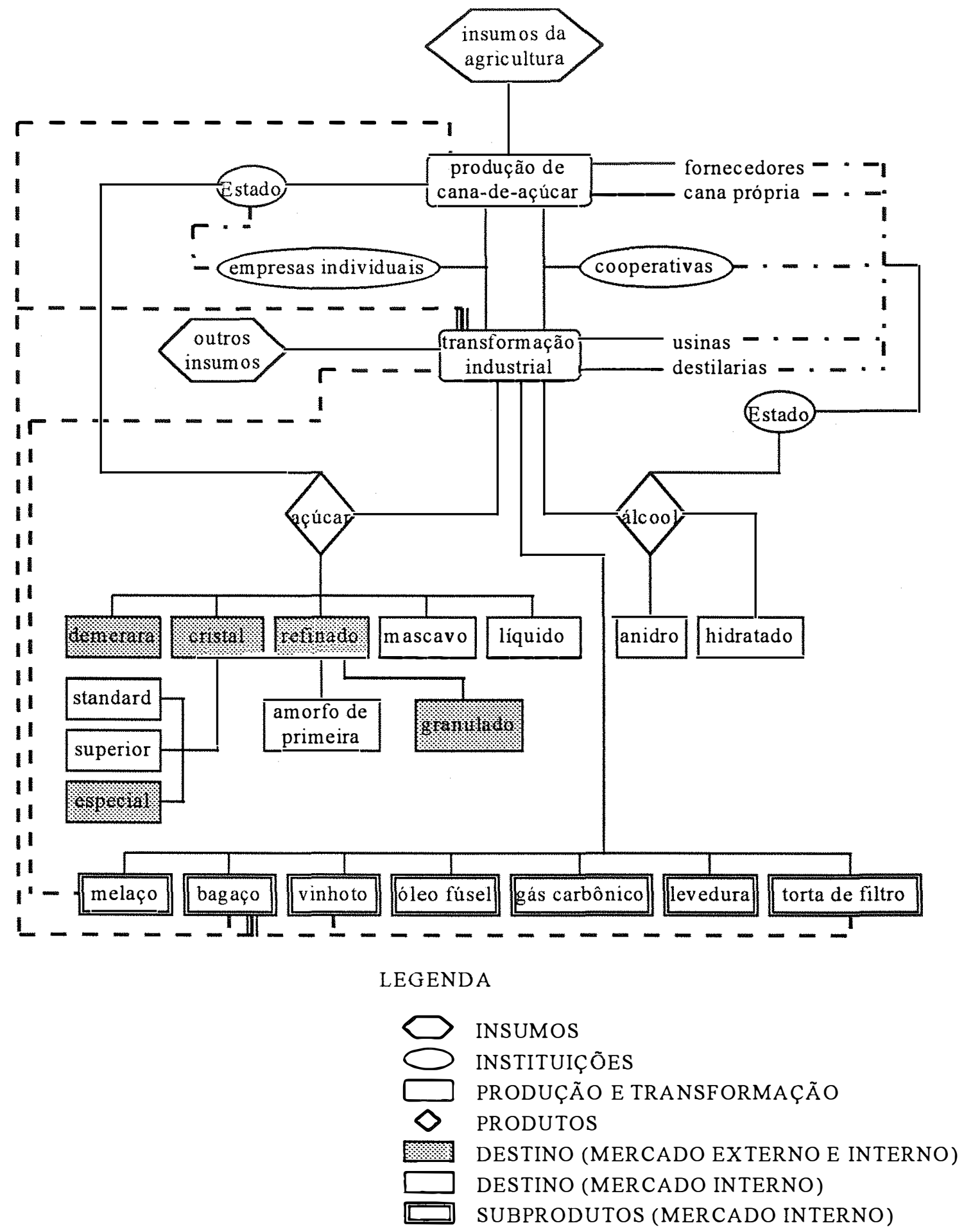

Figura 3 - Fluxograma do eixo agroindústria-mercado do segmento canavieiro 
Após a extinção do IAA, através da Medida Provisória no 151 (15/03/1990), foi visivel o arrefecimento do intervencionismo estatal na agroindústria canavieira. Não obstante, tal arrefecimento foi apenas relativo (principalmente se comparado com fases anteriores), posto que todas as atribuições do IAA foram, através do Decreto no 99.288 (06/06/1990), transferidas para a Secretaria de Desenvolvimento Regional (SDR), que é subordinada à Presidência da República (Lima, 1992).

Olalde (1993) ressalta que embora tenha continuado a vigorar a prática de fixação de quotas e planejamento de safras, desta vez a cargo da SDR, no âmbito do Departamento de Assuntos Sucroalcooleiros, a privatização das exportações foi a principal mudança verificada nesse novo panorama de desregulamentação gradual na agroindústria canavieira na primeira metade da década de 90 .

$\mathrm{Na}$ agroindústria canavieira brasileira verifica-se uma centralização do capital, via concentrações industrial e fundiária, que revertem-se, neste caso, em concentrações técnica e econômica (Ramos, 1983 e 1991). Embora exista essa concentração, as empresas marginais possuem uma parcela não desprezivel da produção. Ademais, pelo fato da concorrência via preços não ser muito forte devido ao intervencionismo estatal neste setor - responsável, entre outras coisas, pela fixação de preços e distribuição de quotas de produção -, mas onde um bom número de produtores sofre grandes variações em função da fase do ciclo econômico, pode-se aferir à agroindústria canavieira características próximas a um oligopólio competitivo (Moreira, E., 1989).

\subsection{GeraÇÃo de TECNOLOGIA E PRINCIPAis PROdUTOS E SUBPRODUTOS}

Em termos de desenvolvimento tecnológico da agroindústria canavieira, Macedo (1996) destaca três importantes fases entre 1975 e 1995: entre 1975 e 1981-1982, ocorreu a fase da busca pela maior produtividade; posteriormente, entre 1981-1982 e 1985, ocorreu a busca pela maior eficiência na conversão da sacarose para o produto final e redução de custos; a fase atual, cujo início data de 1985, está sendo caracterizada pelo gerenciamento global da produção agrícola e industrial. Nesse esforço de geração de tecnologia se destacam a COPERSUCAR, o PLANALSUCAR (até sua extinção), algumas empresas mistas e industriais (IPT, Dedini, entre outras) e usinas independentes. 
No tocante às estratégias tecnológicas verificadas pelas firmas na agroindústria canavieira, as empresas mais modernas da COPERSUCAR são um bom exemplo de adoção de uma estratégia semelhante à estratégia ofensiva descrita por Freeman (1974), ou seja, caracteristicamente intensiva em $P \& D$ e com elevado nível de pesquisa aplicada (veja item 2.1.1.2). Isto, vis-à-vis as outras firmas da agroindústria canavieira.

Constata-se, a partir da interpretação de estudos de Lima (1988a e 1988b), Lima \& Melo (1989), Olalde (1993) e Eid (1996), que as demais empresas da agroindústria canavieira oscilam entre as outras estratégias ressaltadas por Freeman (1974). É o caso de algumas grandes usinas paulistas não filiadas à COPERSUCAR, que adotam estratégia semelhante à defensiva (também intensiva em $\mathrm{P} \& \mathrm{D}$, mas avessa ao risco); ou em outro extremo, no caso de boa parte das usinas e destilarias nordestinas, mineiras e fluminenses, que adotam estratégia semelhante à dependente (estabelece relação de dependência institucional e/ou econômica com outras firmas) e oportunista (a firma busca preencher nichos de mercado)

Segundo Belik (1985) e Macedo (1996), o esforço de pesquisa da COPERSUCAR tem refletido positivamente em diversas áreas da agroindústria canavieira. Na área de melhoramento genético há o desenvolvimento das variedades SP, sendo que esse programa da COPERSUCAR produz cerca de 600.000 plantas independentes por ano, num ramo onde são necessários de dez a doze anos para produção de uma nova variedade comercial. O gerenciamento da produção agrícola tem utilizado instrumentos como mapas do solo e imagens de satélite para identificação varietal e registro de microclima, declividades, adubação, distância, etc. Outros melhoramentos estão sendo obtidos na colheita, com redução do consumo médio de combustível; no transporte, com o uso do rodotrem, um veículo mais eficiente constituído de cinco contêineres para transporte da cana, acoplado a uma estação de transbordo; no gerenciamento agrícola, com o reaproveitamento da vinhaça, desenvolvimento e aplicação do misturador de resíduos no campo e do rastelo rotativo; e na área de organização do trabalho agrícola, destacando-se o corte de cana em sete ruas, que diminuiu as perdas e praticamente anulou a ocorrência de impurezas carregadas juntamente com a cana. Na área industrial a COPERSUCAR vem obtendo êxitos no nível de extração, no tratamento do caldo e fermentação, na destilação e na área energética com o aproveitamento do bagaço da cana. Convém ressaltar que a tecnologia 
desenvolvida pelo Centro Tecnológico da COPERSUCAR (CTC) permite a redução adicional do custo médio do álcool em cerca de $30 \%$, considerando o potencial de redução dos custos agrícolas $(22,2 \%)$ e dos custos industriais $(8,1 \%)$, segundo Lopes (1996).

Todo este trabalho da COPERSUCAR é um elemento capaz de distinguir suas usinas e destilarias associadas das demais, contribuindo para uma evolução diferenciada da agroindústria canavieira, na medida em que os estabelecimentos associados a essa Cooperativa se concentram em São Paulo. Não obstante, Eid (1996) enfatiza a heterogeneidade em termos de uso de novas tecnologias e novas técnicas de gestão dentro da própria COPERSUCAR, onde coexistem usinas entre as mais modernas do País e outras menos modernas. Deve-se levar "(...) em consideração que entre as usinas cooperadas da COPERSUCAR encontram-se usinas modernas em termos de uso de novas tecnologias e, outras menos modernas, com uso da tecnologia tradicional" (Eid, 1996, p.34).

Segundo apontamentos de Belik (1985) a COPERSUCAR gastava, em meados dos anos 80 , US\$ 7 milhões por ano em pesquisa ( $0,8 \%$ da receita bruta da empresa), absorvendo cerca de 120 técnicos, sendo $30 \%$ com qualificação profissional em termos de mestrado e doutorado, contando também com uma razoável infra-estrutura fisica, disposta em $10.000 \mathrm{~m}^{2}$ de laboratórios e 3.000 ha de campos experimentais. Atualmente, a COPERSUCAR gasta em pesquisa cerca de $1 \%$ da receita bruta da empresa.

Todavia, a partir de 1990, a COPERSUCAR iniciou um processo de contenção de despesas na área tecnológica. Diante de uma avaliação técnica de que seu programa de capacitação tecnológica estaria superdimensionado, e tendo em conta a crise de rentabilidade que afetou a agroindústria canavieira a partir da segunda metade dos anos 80 , foram demitidos $54 \%$ do pessoal ocupado nessa atividade, além de serem fechadas 5 das 9 estações experimentais da COPERSUCAR (Olalde, 1993). Mesmo com essa conjuntura de cortes de despesas, a presença da COPERSUCAR na área de capacitação tecnológica continua sendo significativa e hegemônica, principalmente após a extinção do PLANALSUCAR (em 1990).

No que concerne ao desenvolvimento tecnológico da lavoura canavieira, o IAA implementou em 1971 o Programa Nacional de Melhoramento da Cana-de-Açúcar - 
PLANALSUCAR, com a finalidade de melhorar a qualidade da matéria-prima para a agroindústria açucareira, bem como racionalizar sua produção. A atuação do PLANALSUCAR, diferentemente da COPERSUCAR, estendeu-se também ao Nordeste, permitindo, inclusive, a elevação da produção de açúcar de $8 \%$ a $25 \%$ por hectare cultivado nessa região (Carvalho \& Caron, 1982).

Belik (1985, p.110), a partir de estudos de Benakouche (1981), destaca "(..) que para o Centro-Sul houve uma clara divisão de tarefas entre o PLANALSUCAR e COPERSUCAR, cabendo ao primeiro mais o domínio não-econômico $e$ à COPERSUCAR o domínio econômico". Neste caso, considera-se domínio nãoeconômico uma parcela da pesquisa tecnológica não prontamente transformável em valores econômicos (Benakouche, 1981).

Após a extinção do IAA em 1990, o PLANALSUCAR passou por uma crise de indefinição institucional, sendo esta crise parcialmente solucionada a partir da proposta de absorção dos técnicos e de toda a infra-estrutura desse órgão pelas universidades federais de cada região de atuação desse órgão (o PLANALSUCAR). Entretanto, o locus da pesquisa canavieira permanece indefinido, e ainda não existe uma dotação orçamentária específica para tais atividades; os pesquisadores, agora também docentes, vivem um processo de adaptação às novas funções, muitos dos quais buscando uma melhor qualificação (Olalde, 1993).

Além da COPERSUCAR e do extinto PLANALSUCAR, existem alguns estabelecimentos independentes na agroindústria canavieira que também se preocupam com o desenvolvimento tecnológico. Eid (1996) chama a atenção para duas usinas de grande porte e não filiadas à COPERSUCAR, Usina da Barra e Usina Santa Elisa (ambas em São Paulo), que introduziram novas tecnologias, inovações organizacionais e o reaproveitamento integral dos resíduos do processamento industrial. A Usina da Barra, por exemplo, ainda possui um laboratório entomológico, desenvolvendo importantes pesquisas para o controle biológico da broca da cana (Diatraea Saccharalis).

Numa direção contrária, a estratégia das pequenas empresas da agroindústria canavieira não tem sido o desenvolvimento interno de tecnologia e sim a incorporação de insumos melhorados comercializados pelas grandes empresas (Olalde, 1993). Remontando aos conceitos apresentados por Freeman (1974), pode-se caracterizar a 
estratégia dessas pequenas empresas como próximas às estratégias dependente e/ou oportunista.

Especificamente na área de pesquisa industrial do segmento canavieiro, a maior parte das atividades de $\mathrm{P} \& \mathrm{D}$ se concentram "(...) no redesenho dos componentes que apresentam-se como um gargalo nos equipamentos já disponíveis e na atualização tecnológica, a partir da transferência e adaptação da tecnologia estrangeira" (Olalde, 1993, p.66). Neste aspecto, o aprendizado dos processos industriais, learning-by-using (LBU), é o mais comum, embora sejam verificados casos de learning-by-doing (LBD) no próprio Centro Tecnológico da COPERSUCAR, na indústria brasileira de equipamentos para o setor produtor de açúcar e álcool - por exemplo, através dos grupos Dedini e Zanini (Negri, 1981) -, e no Instituto de Pesquisas Tecnológicas do Estado de São Paulo (IPT) - em trabalhos de pesquisa ligados à área de fermentação alcoólica e, mais recentemente, no desenvolvimento do ecoplástico a partir de cana-de-açúcar.

Vale anotar que com a implantação do PROÁlCOOL (em 1975), a indústria automobilística, após lacônico receio, desenvolveu pioneiramente uma moderna tecnologia para veículos movidos a álcool (mas, ainda não suficiente para tornar esse veículo mais atraente, do ponto de vista econômico, vis-à-vis o veículo movido a gasolina), contando com o apoio de vários centros de pesquisas ligados às universidades brasileiras.

Embora os arranjos institucionais que vigoraram por um bom tempo na agroindústria canavieira não estimulem maiores inversões em pesquisas, toda essa geração de tecnologia apontada tem como intento desenvolver novas técnicas de produção e gestão, bem como oferecer ao mercado produtos cada vez mais competitivos. Neste tocante, pela sua própria especificidade, a importância econômica da cana-deaçúcar está diretamente ligada aos diversos produtos e subprodutos advindos dessa cultura e à sua multiplicidade de funções (Szmrecsányi, 1979).

$\mathrm{Na}$ figura 3 foram destacados os principais produtos e subprodutos (também chamados de co-produtos) da agroindústria canavieira brasileira. A maioria dos itens realçados tem como destino o mercado interno. Apenas o açúcar demerara, cristal especial e refinado granulado possuem duplo destino, isto é, podem se direcionar para o mercado interno e/ou externo, de acordo com a conjuntura. 
Os principais produtos da agroindústria da cana-de-açúcar são o açúcar e o álcool. De acordo com Canto (1986), $1000 \mathrm{~kg}$ de cana-de-açúcar podem gerar $90 \mathrm{~kg}$ de açúcar, $45 \mathrm{~kg}$ de melaço, $300 \mathrm{~kg}$ de bagaço e 12 litros de álcool (no caso de orientação para produção de açúcar e álcool, sendo este último residual); ou $1000 \mathrm{~kg}$ de cana-deaçúcar podem gerar $300 \mathrm{~kg}$ de bagaço e 67 litros de álcool (no caso de orientação para produção de álcool). Em estudo mais recente, Stalder \& Burnquist (1995) ressaltam as seguintes especificações: $1000 \mathrm{~kg}$ de cana-de-açúcar podem gerar $100 \mathrm{~kg}$ de açúcar, 280 $\mathrm{kg}$ de bagaço e 13,3 litros de álcool residual, ou 72,5 litros somente de álcool. Cabe ressaltar que as proporções existentes entre os produtos e subprodutos da transformação industrial da cana-de-açúcar irão depender do tipo de especificação da unidade produtora, variando ainda "(...) de acordo com as condições de solo e clima e eficiência dos métodos e maquinaria adotados" (Renault, 1978, p.54).

Quanto ao produto açúcar, este pode materializar-se em cerca de cinco tipos, quais sejam: o açúcar demerara, cristal, refinado, mascavo e líquido. ${ }^{10} \mathrm{O}$ açúcar demerara, ou bruto, é produzido para exportação, com uma fração praticamente desprezível de sua produção destinada ao mercado doméstico. Trata-se de um açúcar ligeiramente amarelado, contendo $97 \%$ de sacarose. O açúcar cristal apresenta teor de sacarose variando de $99,3 \%$ a 99,7\%, recebe ainda a denominação genérica de açúcar branco, podendo ser classificado de acordo com seu teor de sacarose, de umidade, de cinza e de cor, com a seguinte gradação: standard - de menor qualidade, destina-se ao mercado interno; superior - de qualidade intermediária, destina-se ao mercado interno; especial de melhor qualidade dentre estes, destina-se ao mercado externo e interno. $\mathrm{O}$ açúcar refinado tipo granulado contém no mínimo $99,8 \%$ de sacarose, enquanto o açúcar refinado tipo amorfo contém no mínimo $99 \%$ de sacarose; ambos são obtidos a partir do açúcar cristal ou demerara, após a operação de refino. O açúcar mascavo (cristalizado por choque) e o líquido (não cristalizado) são pouco comercializados no Brasil.

A partir da cana-de-açúcar são produzidos três tipos de álcool: álcool hidratado, álcool anidro e álcool etílico. Os dois primeiros tipos de álcool (onde centra-se a atenção desse trabalho) destinam-se, em grande parte, ao mercado interno. Já uma pequena fração

\footnotetext{
${ }^{10}$ Esta descrição técnica de produtos e subprodutos da cana-de-açúcar baseia-se em Renault (1978) e CEMIG (1990). Sobre as considerações agronômicas da cana-de-açúcar e aspectos do processo produtivo, ver: Szmrecsányi (1979), COPERSUCAR (1988) e Veiga Filho et al. (1994).
} 
da produção nacional de álcool etílico tem sido ocasionalmente exportada (BACEN, 1992; AGRIANUAL 96).

Além de sua finalidade energética, para fins carburantes, o álcool extraído da cana-de-açúcar pode ser utilizado principalmente na indústria química, farmacêutica, de cosméticos e de bebidas.

O álcool hidratado, uma mistura binária álcool-água, tem teor alcoólico de 92,6 a 93,8 graus de INPM - medida do teor alcoólico em percentagem em massa nas misturas hidroalcoólicas - medidos a $20^{\circ} \mathrm{C}$; enquanto o álcool anidro, ausente de água, tem teor alcoólico mínimo de 99,3\% INPM medidos a 200 C. O primeiro é utilizado como combustível em motores de ciclo OTTO, enquanto o segundo é adicionado à gasolina, "(...) visando não apenas a redução do consumo do derivado do petróleo, mas também a eliminação da adição de chumbo tetraetila (tóxico) com o objetivo de aumentar a octanagem" (CEMIG, 1990, p.06).

Os estabelecimentos produtores de açúcar e álcool são classificados de acordo com o produto final que geram, denominando-se o estabelecimento que produz açúcar de usina; e de destilaria o estabelecimento que produz álcool. No que respeita às destilarias, estas podem ser classificadas em anexa ou autônoma. A destilaria anexa consome uma proporção da cana esmagada por uma usina a ela ligada, já a destilaria autônoma funciona independentemente de outra unidade produtiva, sendo a cana esmagada destinada apenas à produção de álcool.

Nos processos de transformação industrial do açúcar e/ou álcool são gerados alguns subprodutos (vide figura 3). Entretanto, somente a partir do recrusdecimento da crise na agroindústria canavieira, a partir de 1986, é que esses subprodutos começaram a ganhar maior interesse de mercado. Neste contexto, esforços estão sendo dirigidos pelas usinas e destilarias para otimizar o uso desses subprodutos, seja na sua própria agroindústria (para principalmente reduzir custos de produção) ou para venda a outro setor da economia (para aumentar a receita da empresa).

Sobre a aplicabilidade dos principais subprodutos da cana-de-açúcar, o melaço resíduo não cristalizável da produção de açúcar, conhecido também pela denominação de mel pobre ou mel esgotado - pode ser aproveitado como ração animal, servindo ainda 
como matéria-prima para a produção de álcool em destilarias anexas. O melado, que é o melaço purificado, pode ser utilizado para consumo humano.

O bagaço - resíduo da cana-de-açúcar após a extração do caldo, constituído de material celulósico, cinzas, açúcar residual, sais minerais e outros solúveis além de água apresenta utilidade como ração animal, combustível utilizado na transformação industrial da própria cana ou de outro estabelecimento que necessite dessa fonte. Pode ser utilizado ainda como adubo, na co-geração de energia elétrica e para a produção de celulose.

De acordo com COPERSUCAR (1989b), o mercado de bagaço no estado de São Paulo é estimado em cerca de 1,7 milhão de toneladas anuais, sendo a comercialização deste produto feita a um preço correspondente a $45 \%$ do preço do óleo combustível energeticamente equivalente. Segundo a referência citada, as usinas e destilarias filiadas à COPERSUCAR auto-produzem aproximadamente $80 \%$ do total de energia elétrica que consomem. Outrossim, já existem contratos no Nordeste e em São Paulo para a cogeração de energia elétrica a partir do bagaço da cana, sendo fornecidos 14,9 mw e $8 \mathrm{mw}$, respectivamente. Os dois principais obstáculos para a ampliação dessa co-geração estão relacionados ao baixo preço pago pela energia gerada e aos altos investimentos necessários nas caldeiras de alta pressão e gaseificação do bagaço (Olalde, 1993).

O resíduo da destilação do vinho, denominado vinhoto (ou, ainda, vinhaça ou restilo), pode ser utilizado, sob determinados critérios técnicos, como fertilizante no próprio canavial. Este resíduo, produzido numa proporção de 12 a 15 litros para cada litro de álcool, é rico em potássio, além de conter outros nutrientes como o nitrogênio, enxofre, cálcio e magnésio. "A aplicação de $150 \mathrm{~m}^{3}$ do residuo (em um hectare) substitui $412 \mathrm{~kg}$ de potássio ou $690 \mathrm{~kg}$ de cloreto de potássio, correspondendo a um benefício de US\$ 83" (COPERSUCAR, 1989b, p.43). Segundo Szmrecsányi (1994), embora o vinhoto possa ser empregado com sucesso como fertilizante, sua aplicabilidade não pode ser excessiva nem indiscriminada, sob pena de ocorrências como a salinização dos solos e/ou mediante a poluição dos cursos d'água subterrâneos.

A utilização do vinhoto para a produção de biogás - que pode ser direcionado tanto para a redução do consumo de diesel na frota motomecanizada das usinas e destilarias, quanto para a queima em caldeiras - ainda demanda estudos. Contudo, alguns estabelecimentos já estão implantando sistemas de biodigestores. Mesmo assim, parte 
deste resíduo continua sendo rejeitado, fato este que requer tratamento prévio, nem sempre efetuado, devido à sua alta carga poluidora e seu baixo $\mathrm{pH}$.

O óleo fúsel, constituído de álcoois homólogos superiores, é obtido como produto secundário da fermentação e separado na destilação. Pode ser utilizado na indústria química, particularmente na indústria de tintas e solventes, e na obtenção de aromatizantes industriais.

O gás carbônico $\left(\mathrm{CO}_{2}\right)$ continua tendo pouca utilização econômica, pois grande parte das usinas utilizam dornas (recipientes onde ocorre a fermentação) abertas, o que impossibilita o aproveitamento desse elemento. $\mathrm{O} \mathrm{CO}_{2}$ pode ser aproveitado para a produção de gelo seco e gaseificação de bebidas.

As leveduras, provenientes da fermentação alcoólica, e a torta de filtro, provenientes do processo de tratamento do caldo, podem ser utilizadas, respectivamente, como ração de gado ou como adubo. No caso das leveduras, é preciso ressaltar que sua comercialização ainda é problemática, visto que os preços obtidos não têm sido atraentes. Ademais, no mercado de ração para gado existe um sério concorrente, de menor custo de produção; trata-se do farelo de soja (Olalde, 1993).

A obtenção de resinas termoplásticas, derivadas de culturas bacterianas alimentadas com sacarose, apresenta-se como uma alternativa produtiva para a agroindústria canavieira, principalmente se se considerar as pressões cada vez maiores dos movimentos ambientalistas. Este novo plástico biodegradável - poli-hidroxi-butirato (PHB) - pode contribuir efetivamente para a diminuição do acúmulo de lixo plástico convencional na terra, desaparecendo nos aterros sanitários em aproximadamente um ano, em lugar dos 20 a 40 anos necessários para o desaparecimento de seus análogos de procedência fóssil (Nothenberg, 1995). No Brasil, o IPT, em conjunto com a COPERSUCAR e a Universidade de São Paulo (USP), estão desenvolvendo pesquisas sobre a obtenção e aproveitamento econômicos desse polímero biodegradável. Por enquanto, a justificativa para a utilização desse material é puramente ecológica, haja vista que seu custo de produção tem sido maior do que o plástico convencional.

Após as análises da evolução da agroindústria canavieira brasileira de sua origem até 1974 (capítulo 3), e da organização dessa agroindústria, geração de tecnologia e 
principais produtos e subprodutos (capitulo 4), nosso trabalho passará a concentrar-se na delimitação temporal cujo objetivo é maior (1975-1995). Entrementes, esses dois capítulos precedentes são extremamente válidos porque permitem uma visão histórica fundamental para o entendimento de certos aspectos da atual conjuntura da agroindústria canavieira, além de oferecer um panorama estrutural do que de fato existe no eixo agroindústria-mercado da economia canavieira. Sobre este último ponto, é importante destacar, por exemplo, que o nível de detalhamento em termos dos subprodutos da agroindústria canavieira será útil para o entendimento do capítulo 7 (nesse capítulo verificar-se-á como foram aproveitados os subprodutos derivados da cana-de-açúcar posto que, diante da crise da agroindústria canavieira, um maior número de subprodutos passou a ganhar expressão econômica). 


\section{EVOLUÇĀO DA AGROINDÚSTRIA CANAVIEIRA BRASILEIRA DE}

1975 A 1995

Este capítulo tem como propósito básico apresentar os principais condicionantes da evolução diferenciada ocorrida na agroindústria canavieira do Brasil de 1975 a 1995, à luz do referencial teórico neoschumpeteriano e da análise neocorporatista expostos no capítulo 2. Visando uma melhor exposição dos fatos, analisa-se essa evolução a partir das fases pelas quais passou a agroindústria canavieira. $\mathrm{Na}$ delimitação temporal proposta destacam-se com maior veemência três subperíodos do Programa Nacional do Álcool, quais sejam: 1975 a 1979 (correspondente à expansão "moderada" do PROÁLCOOL), 1980 a 1985 (correspondente à expansão "acelerada" do PROÁLCOOL) e 1986 a 1995 (correspondente à "desaceleração e crise" do PROÁLCOOL).

\subsection{A AGROINDÚSTRIA CANAVIEIRA NO SUBPERÍODO 1975 A 1979:} FASE DE EXPANSÃO "MODERADA" DO PROÁLCOOL

Esta seção tem como propósito analisar a evolução da agroindústria canavieira brasileira durante a $1 \underline{a}$ fase do PROÁLCOOL. Dessa forma, esta seção procura destacar os principais fatores do desenvolvimento tecnológico ocorrido nesse segmento produtivo, especificando pontos como as inter-relações que um plano macroeconômico maior teve sobre esse processo, bem como sua relação com arranjos institucionais e com a heterogeneidade evidenciada entre suas estruturas produtivas.

A criação do PROÁlCOOL se deu no ano de 1975 em meio a uma grave crise do petróleo (esta iniciada em 1973), num período onde a economia brasileira evoluía, segundo Castro \& Souza (1985), em ritmo de "marcha forçada". Os preços do petróleo no mercado internacional em setembro de 1973 eram equivalentes a US\$2,91 por barril. Com a eclosão da Guerra do Yom Kippur (Dia do Perdão) nesse mesmo ano, conflito no 
qual se envolveram diretamente Israel, Egito e Síria, gerou-se nessa região graves perturbações de alcance internacional. Essa crise colaborou de maneira direta para a quadruplicação dos preços do barril do petróleo.

Todavia, cabe anotar, segundo Carneiro (1992), que o fenômeno de quadruplicação dos preços do petróleo foi resultado de um movimento de preços perfeitamente condizente com os arranjos desse mercado para a época. Como matériaprima fundamental para o mundo industrializado, o desajustamento entre o crescimento da demanda por petróleo e os investimentos teria em breve de refletir-se na alta dos preços. Portanto, pode-se aferir que o conflito árabe-israelense contribuiu para a crise do petróleo, mas não foi seu fator exclusivo.

O Brasil, nesse período, dependia em $80 \%$ do petróleo oriundo do exterior. Por conseguinte, o ocorrido refletiu consideravelmente na importação do produto, pois correspondeu ao dispêndio de US $\$ 8,6$ bilhões para a importação de petróleo referente ao triênio 1974-75-76. Para efeito de cotejo, no triênio imediatamente anterior, o dispêndio com a importação de petróleo chegou à quantia de US $\$ 1,4$ bilhões.

Com o desequilíbrio das contas externas brasileiras, causado, em parte, pela crise do petróleo, as autoridades governamentais e fração do empresariado nacional manifestaram interesse em encontrar fontes alternativas para a substituição de alguns derivados do petróleo. Foram propostos alguns Programas com este caráter, dentre os quais: o PROÓLEO (objetivando substituir o óleo diesel), o PROCARVÃO (objetivando substituir o óleo combustível) e o PROÁLCOOL (objetivando substituir a gasolina), sendo o último o que teve maior apoio e resultados. ${ }^{11}$

À primeira vista, um fator externo - crise do petróleo - parece ter determinado, ad hoc, o surgimento do PROÁlCOOL. Segundo Magalhães et al. (1991, p.9), o "Programa nasceu exclusivamente em função de um tipo específico de desequilibrio externo, a saber, dos dois 'choques' de petróleo." Entretanto, esta visão foi bastante criticada. A crise do petróleo teve início em 1973 e o PROÁLCOOL só foi implementado efetivamente a partir de 1975. A maturação dos investimentos necessários ao Programa

\footnotetext{
${ }^{11}$ Tecnicamente, o álcool estava melhor posicionado que o óleo e carvão vegetais em termos de fonte alternativa de energia. Vários autores analisaram os resultados do PROÁLCOOL, por exemplo: Melo \& Fonseca (1981), Pelin (1983), Melo \& Pelin (1984), Gontijo (1985), Motta (1987) Magalhães et al. (1991) e Fernandes \& Coelho (1996).
} 
não era tão grande assim em seu começo, pois a primeira fase do Programa baseou-se sobremaneira na produção de álcool anidro para mistura com a gasolina. Podia-se, portanto, aproveitar a capacidade ociosa do parque alcooleiro nacional, não ocorrendo, então, esse hiato referido. Esse fato levou alguns autores a levantarem outras razões, do que a crise do petróleo, para explicar o surgimento do PROÁLCOOL.

Para Ramos (1991) e Ricci et al. (1994), por exemplo, o fato da execução do PROÁLCOOL só se dar em 1975 esteve relacionado com a breve alta dos preços internacionais do açúcar verificada em meados da década de 70 (Tabela 1). Neste tocante, é importante ressaltar que o mercado externo do açúcar sempre teve uma importância para a agroindústria canavieira, embora apenas $30 \%$, em média, da produção açucareira nacional seja exportada. ${ }^{12}$

Tabela 1 - Valor da exportação de açúcar do Brasil, participação dessa exportação no total das exportações brasileiras e preço médio do açúcar (US\$cents/libra) Mercado Livre, Comunidade Econômica Européia (CEE) e Estados Unidos 1971 a 1979.

\begin{tabular}{cccccc}
\hline Ano & $\begin{array}{c}\text { Valor a bordo no Brasil } \\
\text { (em milhares de dólares) }\end{array}$ & $\begin{array}{c}\text { \% do açúcar no total } \\
\text { das exportacões }\end{array}$ & $\begin{array}{c}\text { Mercado livre } \\
\text { a }\end{array}$ & CEE b & $\begin{array}{c}\text { Estados } \\
\text { Unidos }\end{array}$ \\
\hline 1971 & 152.951 & 5,3 & 4,5 & 5,2 & 7,9 \\
1972 & 403.548 & 10,1 & 7,5 & 6,8 & 8,5 \\
1973 & 558.686 & 9,0 & 9,6 & 6,7 & 10,3 \\
1974 & 1.321 .932 & 16,6 & 29,9 & 10,6 & 29,5 \\
1975 & 1.099 .773 & 12,7 & 20,6 & 15,4 & 22,5 \\
1976 & 306.537 & 3,0 & 11,6 & 13,4 & 13,3 \\
1977 & 462.704 & 3,8 & 8,1 & 14,0 & 11,0 \\
1978 & 350.064 & 2,8 & 7,8 & 15,9 & 14,0 \\
1979 & 363.809 & 2,4 & 9,7 & 19,3 & 15,5 \\
\hline
\end{tabular}

Fonte: compilado de Abbott (1990), FIBGE (1990), FAO (1992), BACEN (1989 e 1991).

Obs.: a) preço da Associação Internacional do Açúcar como uma média do Contrato de Nova York número 11 do mercado spot, e o preço diário de Londres ("Livre a Bordo" - FOB) em portos do Caribe; b) Açúcar a granel ("Custo, Seguro e Frete" - CIF) em portos europeus; c) Preço spot CIF em portos do Golfo do México para o Contrato número 12 de Nova York - sobre a questão dos contratos e perspectivas de preços no mercado internacional do açúcar, ver RICO (1992a e 1992b).

${ }^{12}$ A desestabilização do setor açucareiro mundial, apesar da ocorrência de períodos de breve alta de preços, tem duas razões fundamentais. Primeiro, existem persistentes excessos de oferta de açúcar - a CEE, por exemplo, de antiga importadora passou à condição de grande exportadora de açúcar, graças à política de altos preços do açúcar no mercado interno e ao eficiente mecanismo de gestão de oferta a partir de um sistema de quotas de produção (Jank, 1989). Segundo, existe uma tendência de retração da demanda do açúcar, sobretudo em vista da concorrência do açúcar com os adoçantes sintéticos e outros similares (BACEN, 1986). Para Szmrecsányi (1989, p.168), a contar por estes fatores "(..) pode-se afirmar, sem exagero, que o setor açucareiro é um setor em crise permanente - uma crise da qual não sairá nos próximos anos". Maiores considerações sobre o mercado externo açucareiro, ver: Ministério da Agricultura (1978), Confederação Nacional da Indústria - CNI (1985a e 1985b) e Mendes (1985). 
Com a nova queda dos preços internacionais do açúcar e o aumento das pressões políticas por parte dos usineiros para solucionar a crise de instabilidade da agroindústria açucareira - que já era histórica - pôde o setor direcionar esforços para dar início a tal Programa. Outro acontecimento que concorreu para retardar o lançamento do PROÁLCOOL foi as descobertas de petróleo na Bacia de Campos.

Conciliando as argumentações ora enfatizadas, a interpretação do nosso trabalho é a de que a crise do petróleo e a crise da agroindústria canavieira contribuíram para viabilizar o surgimento do PROÁLCOOL. A crise do petróleo gerou um "gargalo" no processo produtivo. O "gargalo" propicia um ambiente favorável ao surgimento de várias opções; neste caso, foram o uso do álcool, do carvão e do óleo vegetal. Contudo, a crise da agroindústria canavieira acabou favorecendo a "orquestração" de interesses que levou o País a optar pelo PROÁLCOOL. Nessa linha de raciocínio, a crise do petróleo levou ao surgimento de várias inovações, e a "orquestração" de interesses definiu qual proposta foi vitoriosa.

De fato, a alternativa baseada no uso do álcool combustível foi bem formulada politicamente, seja na esfera de interesses privados (de empresários, pessoas e instituições ligadas, direta e indiretamente, à agroindústria canavieira) ou de interesses públicos (à época, através de representantes dos Ministérios da Agricultura, Fazenda, Indústria e Comércio, Interior, Minas e Energia, e Planejamento). Isto não se verificou para qualquer outra opção energética, até porque nas áreas desses programas alternativos não existia uma crise semelhante à crise açucareira, e nem um forte grupo de pressão como o verificado na agroindústria canavieira.

A "orquestração" de interesses para viabilizar o PROÁLCOOL englobou os empresários das usinas e destilarias, o Estado, o setor de máquinas e equipamentos e a indústria automobilística. Para os usineiros tratava-se de diversificar a produção, de "criar" um novo mercado diante das freqüentes crises da economia açucareira. A questão crucial que se colocava para a agroindústria canavieira era o que fazer com um parque produtivo que precisava avançar tecnologicamente e que estava com tendência à sobrecapacidade (Ramos \& Belik, 1989). Para o Estado, os interesses nesse Programa resumiam-se nos objetivos nele contidos, quais sejam: economia de divisas; diminuição das desigualdades regionais de renda; crescimento da renda interna; geração de empregos; e expansão da produção de bens de capital. Neste ínterim, esse Programa 
também era, e ainda é, importante para a continuação das vendas de máquinas e equipamentos para a agroindústria canavieira. Segundo Belik (1992), com o PROÁLCOOL o setor de máquinas e equipamentos (indústria de bens de capital) vislumbraram um quadro de continuidade do crescimento que havia sido iniciado ao final da década de 60 e que atingiu o seu auge no período do "milagre" econômico do País. Especificamente para a indústria automobilística, a crise do petróleo obstaculizava, de certa forma, a continuidade da política rodoviarista peculiar ao desenvolvimento econômico brasileiro, e o carro movido a álcool despontava como uma alternativa passível de viabilização (Belik, 1992). Verifica-se, nestes aspectos, uma semelhança com a endogenia do processo de inovação enfatizado por Schumpeter, conquanto houve a presença de agentes no PROÁLCOOL que visaram o lucro com a abertura desse novo mercado para o álcool.

Pode-se constatar em Belik (1992) que o caso do PROÁLCOOL é um nítido exemplo de meso-corporatismo, no qual a agroindústria canavieira, possuindo interesses bem definidos e atuando em concordância junto aos interesses do Estado e de outras instituições privadas, consegue solidificar uma prática corporativa para gestão de uma ampla política pública. ${ }^{13}$ Política esta que tinha como intento tornar o álcool combustível uma alternativa energética, apesar de bastante custosa (Melo \& Pelin, 1984), pois embora o custo de produção do álcool para as usinas cooperadas à COPERSUCAR tenha reduzido de US\$79/barril, em 1976, para US\$ 47/barril, em 1992, o álcool não era e ainda não é competitivo vis-à-vis a gasolina (Lopes, 1996).

A interação de interesses dentro da própria agroindústria canavieira, nem sempre convergentes, fez surgir outra representação formal de parte do empresariado dessa agroindústria, feita através da Sociedade de Produtores de Açúcar e Álcool - SOPRAL cuja fundação foi em 1975. Para Ramos \& Belik (1989), o relacionamento entre empresários da agroindústria canavieira e órgãos variados na esfera federal contribuiu para reforçar a representatividade de classes e dos seus lobbies no interior do aparelho estatal. A SOPRAL, por exemplo, surgiu em decorrência de divergências na condução dos interesses alcooleiros no Estado de São Paulo.

\footnotetext{
${ }^{13}$ Não cabe ao presente trabalho pormenorizar como a organização dos grupos de interesses viabilizou a implantação e gestão do PROÁLCOOL, até porque isto foi bem efetuado por Belik (1992). A contribuição maior deste estudo está na inter-relação da análise neocorporatista e neoschumpeteriana para explicar os principais condicionantes da evolução diferenciada ocorrida na agroindústria canavieira do Brasil de 1975 a 1995.
} 
As mudanças porque passou a agroindústria canavieira para a implementação do PROÁLCOOL, capitaneadas pela interação estratégica de interesses privados e públicos ante uma condição histórica particular - crise da economia açucareira e choque do petróleo - possibilitaram a ocorrência de uma série de inovações. Desta forma, podem ser consideradas inovações: o "novo" produto dessa agroindústria - o álcool combustível -; suas modernas técnicas de produção; o "novo" mercado criado e as novas composições agroindustriais instituídas - destilarias autônomas; além do "novo" motor adaptado ao uso desse combustível. Na realidade, é preciso reforçar que experiências sobre a utilização do álcool combustível para veículos automotores remontam à segunda década do presente século (SOPRAL, 1984). Todavia, o pleno desenvolvimento tecnológico não só dos motores a álcool, como também deste próprio produto para fins carburantes, só veio a lograr relativo êxito com o PROÁLCOOL.

Do ponto de vista institucional, o gerenciamento do PROÁLCOOL coube, inicialmente, à Comissão Nacional do Álcool (CNAL), formada por representantes dos Ministérios da Agricultura, Fazenda, Indústria e Comércio, Interior, Minas e Energia e Planejamento (Moreira, E. 1989). Dessa estrutura foi criada, posteriormente, a Comissão Executiva Nacional do Álcool (CENAL), com o objetivo de dar suporte técnico e administrativo à CNAL. O que se constata nessa inovação institucional, segundo Ramos \& Belik (1989, p.210), é o esvaziamento do IAA como órgão regulador do setor, onde "cabia à CENAL analisar o projeto de instalação ou ampliação de destilaria anexa ou autônoma do ponto de vista técnico e econômico (...), cabendo ao IAA estabelecer a cota de produção".

Para a execução do PROÁLCOOL houve um forte apoio oficial, seja sob a forma de financiamentos, incentivos creditícios, incentivos fiscais, subsídios e/ou incentivos de preços (Magalhães et al., 1991). Os instrumentos básicos para implementação do PROÁLCOOL em sua primeira fase consistiam no estabelecimento de preços remuneradores ao álcool, através da paridade com o preço do açúcar; na garantia da compra do produto pela PETROBRÁS; e na criação de linhas de crédito para financiamento das partes agrícola e industrial. Sobre este último instrumento pode-se afirmar que as condições de financiamentos do Programa, tanto para o segmento agrícola como industrial, eram bastante atraentes, é o que retrata Moreira, E. (1989, p.56): 
"Para os investimentos industriais foram instituidos as taxas de '(juros de)' $15 \%$ ao ano para os produtores do Norte/Nordeste e $17 \%$ ao ano para os do Centro-Sul, sem correção monetária. O prazo de amortização era de 12 anos, sendo 3 anos de carência, e o financiamento envolvia 100\% do investimento (a partir de 1977 a parcela financiada foi reduzida para $90 \%$ para o Norte/Nordeste e $80 \%$ para o Centro-Sul). Os investimentos agricolas pagavam uma taxa de $7 \%$ ao ano (metade da taxa de crédito rural), tendo os mesmos prazos que o crédito industrial para investimentos fixos e de 1 a 3 anos para o custeio agrícola."

Um programa do vulto do PROÁLCOOL, que pretendia inserir com sucesso o álcool na matriz energética brasileira, necessitava de um extraordinário volume de investimentos na agroindústria canavieira, haja vista a infra-estrutura de até então, voltada, basicamente, para atender as demandas de alguns setores tradicionais, dentre os quais: cosméticos, produtos farmacêuticos, bebidas e química (detergentes, tintas, vernizes, etc). De 1975 a 1980 foram investidos no PROÁLCOOL US\$1,019 bilhão, sendo $75 \%$ desta quantia advindos de recursos públicos e $25 \%$ advindos de recursos privados (Lopes, 1996). Esta monta foi usada em 209 projetos, na sua maioria visando a instalação ou modernização de destilarias em áreas tradicionais da agroindústria canavieira (destacadamente em São Paulo, Alagoas, Pernambuco e Rio de Janeiro).

Como se vê, o Estado, além do papel de ter que minimizar as incertezas inerentes ao Programa Nacional do Álcool, assumiu um importante papel como fornecedor de crédito nesses empreendimentos, tomando para si a função do capitalista (tomador de risco). Tal fato vai de encontro com o que expôs Rosenberg (1969 e 1982) e Dosi (1984) pois, o grau de incerteza é comumente forte nos momentos iniciais de uma inovação, o que contribui para que as expectativas sejam maiores nessa fase, resultando, conseqüentemente, na entrada de instituições coordenadoras dos diversos interesses entre os agentes econômicos em questão.

A maior parcela dos recursos públicos voltados para o financiamento do PROÁLCOOL era proveniente do Orçamento Monetário Nacional, sendo administrados no âmbito do Banco Central, tendo como base a subconta PROÁlCOOL do Fundo Geral para Agricultura e Indústria - FUNAGRI (Belik, 1992). Também houve recursos provenientes de agências financiadoras internacionais - Banco Mundial - para financiar o 
PROÁLCOOL, com o aval do IAA. A Tabela 2 retrata a evolução percentual das aplicações do PROÁLCOOL durante a sua primeira fase, no âmbito da FUNAGRI.

Tabela 2 - Participação das aplicações do PROÁLCOOL nas aplicações totais do FUNAGRI - 1976 a 1979 (em percentagem).

\begin{tabular}{ccc}
\hline Ano & $\begin{array}{c}\text { Participação no } \\
\text { FUNAGRI }\end{array}$ & $\begin{array}{c}\text { Participação no crédito agroindustrial do } \\
\text { FUNAGRI }\end{array}$ \\
\hline 1976 & 0,1 & 1,1 \\
1977 & 2,4 & 19,0 \\
1978 & 8,5 & 50,0 \\
1979 & 16,0 & 71,1 \\
\hline
\end{tabular}

Fonte: BACEN, citado por Belik (1992, p.129).

Conforme pode-se observar através da Tabela 2, a participação relativa do PROÁLCOOL nesse Fundo começou com apenas 0,1\% em 1976, chegando a atingir $16,0 \%$ em 1979. No tocante às aplicações específicas voltadas para a agroindústria, esse Programa teve um crescimento equivalente a setenta pontos percentuais.

Para Goldin \& Rezende (1993), embora o PROÁLCOOL estivesse inteiramente a cargo do setor privado - o qual, diga-se de passagem, é de capital nacional - seu notável crescimento dependeu de amplas subvenções governamentais. Trata-se, pois, de um caso onde o Estado interferiu no padrão de busca das empresas da agroindústria canavieira, após processos interativos de ajustes de interesses junto à iniciativa privada.

Como grande parte das usinas brasileiras não possuíam destilarias anexas, sendo que a maioria se concentrava em São Paulo, e diante de linhas de crédito em condições extremamente favoráveis, o Estado, ao implementar o PROÁLCOOL, possibilitou além da ampliação das plantas industriais, a própria manutenção da estrutura tradicional da agroindústria canavieira, assentada na produção integrada, na propriedade fundiária e no próprio paternalismo estatal (Ramos, 1991). Além do que, uma peculiaridade importante desse segmento é que suas empresas são, quase todas, de capital nacional, sendo muito comum a presença de grupos de origem familiar no controle de unidades processadoras de açúcar e/ou álcool (Olalde, 1993), que interagem com o Estado no sentido de estabelecer suas operações de rotina, busca e seleção. Dentre os maiores grupos sucroalcooleiros do estado de São Paulo, que têm como eixo principal de seus negócios a produção de açúcar e álcool, Moreira, E. (1989) cita: a familia Ometto e Biagi. Outras famílias que se destacam neste ramo são: Monteiro e Farias, em Pernambuco; Lyra, em Alagoas; Bouchardet, Martins e Azevedo, em Minas Gerais. 
Foram exatamente esses empresários tradicionais da agroindústria canavieira que se transformaram em empresários inovadores, segundo a concepção schumpeteriana, e realizaram as novas combinações, seja por meio do fornecimento de um "novo" produto o álcool combustível - seja por meio do estabelecimento de "novos" processos de produção e de mercado. Segundo Moreira, E. (1989, p.57 e 60), "(...) a primeira fase do PNA teve suas metas de produção garantidas pelos empresários tradicionais do setor que usufruiram, não só do conhecimento e experiência já adquiridos neste ramo de produção, como (...) de investimentos já feitos na indústria e na lavoura (...)."

Os empresários inovadores da agroindústria canavieira ao implementarem essa inovação, neste caso fruto de uma "orquestração" de interesses bem sucedida, transferiram recursos produtivos (públicos e privados) de suas rotinas econômicas em direção ao novo empreendimento que despontava como atraente pelas condições já conhecidas - garantia de mercado, preços remuneradores, financiamentos vantajosos, etc. Diante da possibilidade de realização de lucros acima da média, outros empresários da agroindústria canavieira, e mesmo fora dela, começaram a imitar os empresários inovadores, adentrando-se gradativamente nessa atividade produtiva. De acordo com Ricci et al. (1994), mesmo partilhando de incertezas quanto à consolidação do PROÁLCOOL, uma parcela dos usineiros investiam na produção de álcool, motivados pela disponibilidade de recursos subsidiados pelo Estado, num momento onde a diversificação da produção apresentava-se como solução para superação da crise do açúcar no mercado internacional.

Essa discussão é relevante para demonstrar outro ponto interessante: a heterogeneidade entre os beneficiados com o PROÁLCOOL durante 1975-1979. De fato, os grandes beneficiários nessa fase do Programa foram alguns estabelecimentos tradicionais do setor, responsáveis por boa parte da produção de álcool no período (Moreira, E. 1989). Cabe frisar que, nessa primeira fase, o PROÁLCOOL teve como diretriz básica a ênfase no aproveitamento da capacidade ociosa das destilarias anexas às usinas de açúcar pré-existentes, no sentido de contribuir para a produção de álcool anidro correspondente ao adicionamento à gasolina. Os estados mais beneficiados com esta política foram, inicialmente, São Paulo, Alagoas, Pernambuco e Rio de Janeiro, que, reunidos, detiveram cerca de $80,8 \%$, em média, do número de destilarias no triênio 1977 1979 (Tabela 3). Neste contexto, a participação das destilarias e usinas de São Paulo no total nacional foram de, respectivamente, $49,9 \%$ e $37,3 \%$, em média. O Centro-Sul foi 
responsável por $58,6 \%$ do número de usinas e por $73,8 \%$ do número de destilarias. Se se considerar o total de cana moída segundo o destino (açúcar ou álcool), verificar-se-á a participação de São Paulo no total nacional de, respectivamente, 45,0\% e 75,5\%, em média, para as safras 1978/79 e 1979/80. Nesta relação, o Centro-Sul foi responsável por, respectivamente, $62,8 \%$ e $83,3 \%$. Estas colocações retratam a superioridade, em termos do número de estabelecimentos e do total de cana moída segundo o destino, de São Paulo perante os demais estados da União e da macrorregião Centro-Sul frente à macrorregião Norte/Nordeste, denotando o caráter diferenciado da evolução da agroindústria canavieira. Conforme Schumpeter assinalou, as inovações tendem a se concentrar em alguns setores da economia, sendo seu processo de difusão eminentemente desigual.

Tabela 3 - Distribuição espacial das usinas de açúcar (U) e destilarias de álcool (D) no Brasil, segundo macrorregião (Centro-Sul; Norte/Nordeste) e principais estados produtores - 1975 a 1979

\begin{tabular}{|c|c|c|c|c|c|c|c|c|c|c|c|c|c|c|c|c|}
\hline \multirow[t]{2}{*}{ Ano } & \multicolumn{2}{|c|}{ Brasil } & \multicolumn{2}{|c|}{$\mathrm{SP}$} & \multicolumn{2}{|c|}{$\mathrm{MG}$} & \multicolumn{2}{|c|}{$\mathrm{RJ}$} & \multicolumn{2}{|c|}{$\begin{array}{c}\text { Centro- } \\
\text { Sul }\end{array}$} & \multicolumn{2}{|c|}{$\mathrm{PE}$} & \multicolumn{2}{|c|}{$\mathrm{AL}$} & \multicolumn{2}{|c|}{$\begin{array}{c}\text { Nortel } \\
\text { Nordeste } \\
\end{array}$} \\
\hline & $\mathrm{U}$ & $\mathrm{D}$ & $\mathrm{U}$ & $\mathrm{D}$ & $\mathrm{U}$ & $\mathrm{D}$ & $\mathrm{U}$ & $\mathrm{D}$ & $\mathrm{U}$ & D & $\mathrm{U}$ & $\mathrm{D}$ & $\mathrm{U}$ & $\mathrm{D}$ & $\mathrm{U}$ & $\mathrm{D}$ \\
\hline 1975 & 209 & $\ldots$ & 79 & $\ldots$ & 14 & $\ldots$ & 17 & $\ldots$ & 123 & ‥ & 36 & $\ldots$ & 27 & $\ldots$ & 86 & $\ldots$ \\
\hline 1976 & 205 & $\ldots$ & 77 & $\ldots$ & 14 & $\ldots$ & 17 & $\ldots$ & 121 & $\ldots$ & 36 & $\ldots$ & 27 & $\ldots$ & 84 & \\
\hline 1977 & 206 & 128 & 77 & 69 & 14 & 8 & 17 & 12 & 121 & 99 & 36 & 21 & 27 & 4 & 85 & 29 \\
\hline 1978 & 206 & 150 & 76 & 75 & 14 & 10 & 17 & 16 & 120 & 112 & 36 & 25 & 27 & 5 & 86 & 38 \\
\hline 1979 & 206 & 170 & 76 & 78 & 14 & 9 & 17 & 18 & 120 & 118 & 36 & 25 & 27 & 13 & 86 & 52 \\
\hline
\end{tabular}

Fonte: compilado do ANUÁRIO ESTATISTICO DO BRASIL (1978) - dados de 1975-76-77; e ANUÁRIO ESTATÍSTICO DO BRASIL (1981) - dados de 1978-79.

A Tabela 3 ainda evidencia a redução (verificada em São Paulo) ou constância (verificada em Minas Gerais, Rio de Janeiro, Pernambuco e Alagoas) do número de usinas ao longo do período retratado. Este fato, no entanto, ainda é reflexo do Programa de Apoio à Agroindústria Canavieira (1973) - ex-Programa de Racionalização da Agroindústria Canavieira (1971) -, cujo objetivo consistia em aumentar a produção açucareira via fusões e incorporações de usinas, de forma a modernizar e aumentar a escala de produção das plantas industriais (Moreira, E. 1989). A tendência visualizada neste processo é de concentração da posse de terras, o que vai de encontro com o que Cochrane (1979) enfatizou na sua idéia do treadmill.

À primeira vista, poderiam surgir dúvidas quanto a existência do paradigma subvencionista na agroindústria canavieira. Contudo, é preciso destacar que este processo 
de fusões e incorporações fôra resultado de uma política governamental, onde alguns produtores considerados ineficientes saíram do setor por opção própria.

Para a primeira fase do PROÁLCOOL foi estabelecida a meta de produção de 3 bilhões de litros de álcool na safra 1979/80. Essa meta foi cumprida em 113,2\%. Os Gráficos 1 e 2 mostram, respectivamente, como a produção de álcool baseou-se sobremaneira em destilarias anexas e como foi expressiva a produção de álcool anidro durante a primeira fase do PROÁLCOOL.

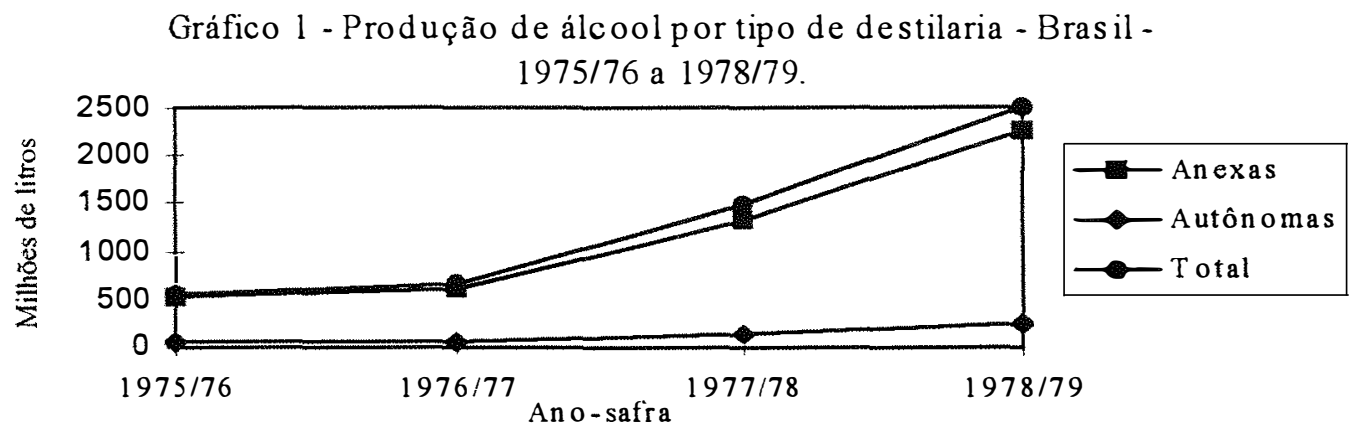

Fonte: IAA (dados primários)

Gráfico 2 - Produção de álcool anidro e hidratado, e consumo d e álcool no Brasil - 1975/76 a 1978/79.

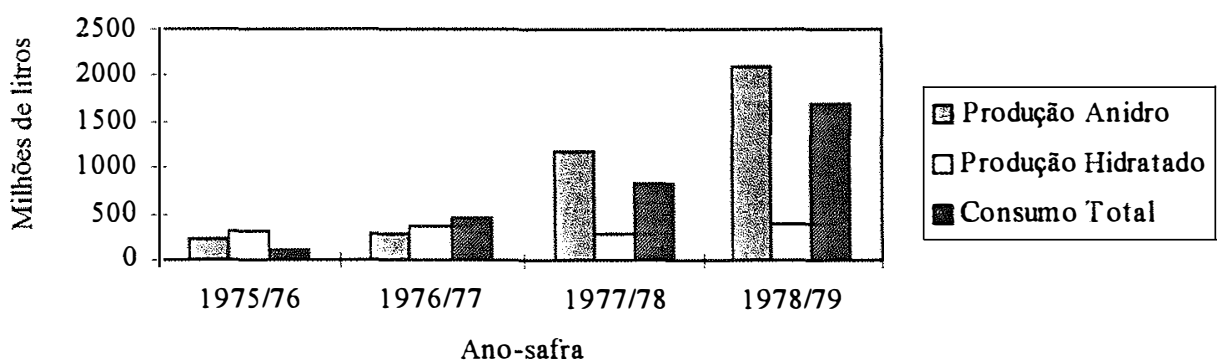

Fonte: IAA (dados primários)

O fato dos maiores beneficiados com o PROÁLCOOL (em sua primeira fase) terem sido poucos produtores e estados, deve-se, em boa medida, à existência de um ambiente de incertezas por parte de fração dos usineiros quanto à consolidação do PROÁLCOOL, sobretudo diante de uma possível recuperação do preço do açúcar no mercado internacional e/ou diante da hesitação da indústria automobilística quanto à viabilidade desse Programa (Ricci et al., 1994). Com efeito, de acordo com a natureza do 
processo inovativo, cada agente irá dispor de um intervalo de tempo no qual o processamento de informações para implementar inovações será feito em um ambiente de incertezas, conforme preconizado pelos neoschumpeterianos, como Dosi (1984).

Neste interim, a busca de consenso entre esses interesses diversos, seja agroindústria canavieira, do Estado e da indústria automobilística, vai ocorrer no âmbito de um processo interativo ao longo das fases do PROÁLCOOL (Belik, 1992); onde os arranjos institucionais terão também a finalidade de minimizar a existência de incertezas. Daí uma das razões para explicar porque no período de 1975 a 1979 houve apenas expansão "moderada" do PROÁlCOOL. Por exemplo, dentro do aparelho do Estado, embora a PETROBRÁS tenha colocado toda a sua estrutura a serviço do PROÁLCOOL, ela relutava contra a implementação desse Programa. Naturalmente, visualiza-se neste confronto o fato dos interesses dos funcionários da PETROBRÁS revestirem-se de aspectos estruturais ligados à necessidade de auto perpetuação de suas funções. $\mathrm{O}$ ponto crítico do Programa Nacional do Álcool para essa Empresa (PETROBRÁS) era a transferência do ônus financeiro dessa atividade para a PETROBRÁS (Rennó, 1995). Outro exemplo diz respeito ao engajamento definitivo da indústria aumobilística ao PROÁLCOOL, ocorrida somente a partir de 1979, com a produção de veículos movidos exclusivamente a álcool. Esta hesitação da indústria aumobilística deveu-se fundamentalmente a pontos que iam desde a falta de confiança no abastecimento de álcool, até ao conhecimento da baixa competitividade do álcool combustível vis-à-vis a gasolina automotiva, gerando incertezas nas expectativas da indústria automobilística. Para Canuto (1991, p.317), "a própria avaliação dos sinais tecnológicos e econômicos está sujeito, em cada caso, não só a reformulação particular de expectativas em condições de incerteza, como também a diferentes propensões a assumir riscos, resguardar fatias de mercado, adotar estratégias agressivas, etc."

O fato do produtor da agroindústria canavieira adentrar no paradigma subvencionista patrocinado pelo Estado, intensificado com o PROÁLCOOL, diminui a existência de incertezas nesse segmento produtivo, posto haver, entre outras vantagens, a garantia de mercado para o álcool combustível.

A seção seguinte evidenciará a fase de expansão "acelerada" desse Programa, onde um maior número de empresários imitadores irão aderir à esta iniciativa, o que, por si só, já denota um panorama menor de incertezas. 


\subsection{A AGROINDÚSTRIA CANAVIEIRA NO SUBPERÍODO 1980 A 1985: FASE DE EXPANSÃO "ACELERADA" DO PROÁLCOOL}

Nesta seção procura-se dar continuidade à análise da evolução da agroindústria canavieira brasileira, enfatizando o subperíodo 1980-1985, conhecido como de maior dinamismo do PROÁLCOOL.

Conforme exposto na seção anterior, a política de investimentos no Programa Nacional do Álcool durante 1975 a 1979 teve como diretriz básica a ênfase no aproveitamento da capacidade ociosa das destilarias anexas às usinas de açúcar préexistentes, no sentido de contribuir para a expansão da produção de álcool anidro (a ser adicionado à gasolina). Na segunda fase do PROÁLCOOL, diante de um novo conflito no Oriente Médio - entre Irã e Iraque, que contribuiu para que os preços do petróleo atingissem patamares elevados (mais de US\$ 30 o barril dessa matéria-prima) - e diante de uma majoração das taxas de juros internacionais ${ }^{14}$, acelerou-se a implementação do uso do álcool hidratado como combustível único e deu-se mais ênfase à implantação de destilarias autônomas. Dessa vez o Programa objetivou alcançar a produção de 10,7 bilhões de litros em 1985, ou seja, mais do que triplicar a produção em aproximadamente 7 anos, além de fortalecer seus propósitos iniciais (economia de divisas, geração de empregos, etc).

Nessa segunda fase do PROÁLCOOL verificaram-se três movimentos - não estanques - importantes para uma maior alavancagem do PROÁLCOOL. Primeiro, no âmbito da agroindústria canavieira, intensificou-se a produção de álcool hidratado a partir da expansão das destilarias autônomas - estas independentes das usinas existentes e voltadas unicamente para a produção alcooleira. Durante a primeira fase do PROÁLCOOL a produção de álcool anidro aumentou quase 12 vezes, enquanto a produção de álcool hidratado duplicou. Ao revés, durante a segunda fase a produção de

\footnotetext{
${ }^{14}$ Segundo Allain (1989), durante o governo Reagan, a politica econômica norte-americana se pautou pela redução de impostos, ampliação dos gastos militares e pela contração da base monetária. O resultado dessa política foi o aumento do déficit governamental que, aliado ao déficit comercial norte-americano, impôs ao governo Reagan a adoção de uma política de absorção de capitais estrangeiros como forma de financiamento dos referidos déficits. A elevação das taxas de juros interna foi um instrumental utilizado para esta finalidade e, dado o peso da economia norte-americana no panorama internacional, isto refletiu-se numa elevação das taxas de juros internacionais.
} 
álcool anidro não chegou nem a duplicar, enquanto a produção de álcool hidratado aumentou quase 13 vezes.

Segundo, no âmbito do Estado, a PETROBRÁS continuou responsável pela comercialização do álcool, dando ao produtor certa garantia de compra do produto, além de dividir com os produtores parte dos custos de estocagem (Olalde, 1993). Foram tomadas medidas inovadoras de estímulo ao uso do veículo movido exclusivamente a álcool, como: a redução da alíquota do Imposto sobre Produtos Industrializados (IPI) e da Taxa Rodoviária Única (atual Imposto sobre Propriedade de Veículos Automotores) para veículos privados dessa natureza, isenção do IPI para táxis a álcool, e o estabelecimento de um limite do preço ao consumidor de álcool hidratado de $65 \%$ em relação ao preço da gasolina - para compensar a equivalência energética entre o álcool e a gasolina, que mantinha-se em torno de 0,75 litros de gasolina para cada litro de álcool (Olalde, 1993). Foi definida, também, a obrigatoriedade de adicionamento de $22 \%$ de álcool anidro à gasolina. Para os produtores de álcool, segundo Moreira, E. (1989), foi instituída uma melhora nos preços desse produto com a redução da paridade de $60 \mathrm{~kg}$ de açúcar por 44 litros de álcool, para $60 \mathrm{~kg}$ de açúcar por 38 litros de álcool, tornando mais compensador a produção do álcool. Do ponto de vista institucional, incluiu-se como agentes financeiros do PROÁLCOOL alguns bancos comerciais privados, bancos de investimento e caixas econômicas, afim de aumentar o raio de ação dos financiamentos dirigidos ao Programa. Ademais, as condições de financiamento dos investimentos patrocinadas pelo Estado continuaram vantajosas, é o que cita Moreira, E. (1989, p.61):

"Embora a partir de 1979 tivesse sido instituida a correção monetária nos financiamentos, ela foi limitada a $40 \%$ da variação das ORTN (em julho de 1981 o limite foi elevado para 70\%), (...) o que significou uma toxa extremamente baixa, dada a aceleração do processo inflacionário. A título de exemplo, uma destilaria autônoma da região Centro-Sul que tenha financiado suas instalações em 1979 (o limite do financiamento era de $80 \%$ do investimento total) devolverá ao agente financeiro apenas $14 \%$ do valor recebido, o que representa um subsidio implícito de $86 \%$ dos recursos tomados."

O terceiro impulso à alavancagem do PROÁLCOOL ocorreu nos âmbitos da indústria de máquinas e equipamentos para a agroindústria canavieira e na indústria 
automobilística, onde foram estimuladas suas produções diante da possibilidade de expansão de mercados para seus produtos. Especificamente para a indústria automobilística, entre 1975 a 1979, foram intensificadas algumas pesquisas visando otimizar a utilização do álcool hidratado como combustível único (Moreira, E. 1989). Devido ao considerável esforço tecnológico e de recursos investidos na indústria automobilística para o desenvolvimento do motor a álcool, esta realidade pôde ser implementada já em 1979 (Parro, 1996). Deveras, em setembro de 1979, o Governo e a Associação Nacional de Fabricantes de Veículos Automotores (ANFAVEA) assinaram um protocolo para o estabelecimento de metas mínimas de produção de veículos movidos a álcool hidratado e de conversão anual de motores para este tipo de combustível (Belik, 1992). Nessa fase o learning-by-doing (LBD), derivado do aprendizado via processo produtivo, foi o método que prevaleceu no âmbito da indústria automobilística.

Como se vê, nessa segunda fase do PROÁLCOOL a "orquestração" de interesses foi ainda mais intensa do que na primeira fase, haja vista conseguir reunir interesses que foram desde a indústria de bens de capital até o consumidor final - ou seja, o proprietário de automóvel movido a álcool hidratado - passando por setores como a agricultura, indústria e serviços (Belik, 1992). Segundo Ricci et al. (1994, p.30), "(...) a consolidação do Programa Nacional do Álcool passou a envolver múltiplos interesses para os quais era fundamental." Outrossim, novamente e de uma forma mais intensa do que na primeira fase, o Estado contribuiu para reafirmar o padrão de busca das empresas da agroindústria canavieira, direcionando-as para a produção de álcool hidratado.

Dessa vez, o aprofundamento do "gargalo", provocado pela segunda crise do petróleo, propiciou um ambiente favorável para o lançamento de um novo produto (o álcool hidratado), enquanto a "orquestracão" de interesses procurou oportunamente corroborar a alternativa álcool combustível como a opção energética mais adequada para a substituição de derivados do petróleo, sobrepujando programas como o de óleos vegetais, de florestas energéticas, entre outros. Para Melo \& Pelin (1984, p.2):

"(...) a ocorrência do segundo 'choque' levou as autoridades governamentais, em um ambiente de uma crise externa agravada, a tomarem decisões de fundamental importância sem o maior respaldo econômico, isto é, de maneira precipitada e com a consideração de outros parâmetros que não os econômicos." - grifo nosso. 
Devido à nova amplitude, um maior volume de recursos deveria ser investidos na segunda fase do PROÁLCOOL. Com efeito, aproximadamente US\$ 5,406 bilhões foram investidos neste Programa entre 1980 e 1984, dos quais 56\% sendo capital público e $44 \%$ capital privado (Lopes, 1996). Em relação ao período anterior (1975 a 1980), esta monta expressa um crescimento da ordem $430,5 \%$. Verifica-se a diminuição do percentual de inversões do capital público nesse Programa (de 75\% passou para 56\%), pari passu ao aumento percentual de inversões do capital privado (de $25 \%$ passou para $44 \%$ ). Isto implica numa maior presença de empresários imitadores e na diferenciação do capitalista em relação ao Estado (na qualidade de agente que assume riscos).

Sobre a distribuição dos projetos contratados pelos agentes financeiros do PROÁLCOOL, verifica-se que o Banco do Brasil e os Bancos componentes do sistema do Banco Nacional de Desenvolvimento Econômico e Social (BNDES) concentraram, respectivamente, $65,7 \%$ e $22,9 \%$ dos financiamentos, correspondendo a $66,4 \%$ e $16,6 \%$ da capacidade de produção contratada (dados obtidos junto à CENAL).

A Tabela 4 retrata a evolução da participação das aplicações do PROÁLCOOL nas aplicações totais do FUNAGRI durante o período 1980-1985. Embora este período tenha coincidido com a fase de descenso no FUNAGRI, a partir de 1983, pode-se verificar maiores participações médias nessa segunda fase do PROÁLCOOL relativamente à primeira fase - vide Tabela 2 - (Belik, 1992). A participação relativa média do PROÁLCOOL nesse Fundo durante 1980-1985 foi equivalente a 35,9\%, contra 6,8\% em 1976-1979. No tocante às aplicações específicas voltadas para a agroindústria, houve uma participação média de $83,5 \%$ durante $1980-1985$, contra $35,3 \%$ em 1976 1979.

Tabela 4 - Participação das aplicações do PROÁLCOOL nas aplicações totais do FUNAGRI - 1980 a 1985 (em percentagem).

\begin{tabular}{ccc}
\hline Ano & $\begin{array}{c}\text { Participação no } \\
\text { FUNAGRI }\end{array}$ & $\begin{array}{c}\text { Participação no crédito agroindustrial do } \\
\text { FUNAGRI }\end{array}$ \\
\hline 1980 & 28,9 & 77,4 \\
1981 & 43,3 & 84,1 \\
1982 & 52,0 & 87,2 \\
1983 & 41,0 & 93,1 \\
1984 & 33,8 & 79,4 \\
1985 & 16,6 & 80,1 \\
\hline
\end{tabular}

Fonte: BACEN, citado por Belik (1992, p.129). 
Dados obtidos junto à CENAL mostram aspectos interessantes sobre a distribuição regional dos projetos enquadrados no PROÁLCOOL até fins de 1985. Neste contexto, verifica-se uma maior participação percentual de duas regiões de tradição na agroindústria canavieira, Sudeste (com 58,2\%) e Nordeste (com 21,1\%). A representatividade das regiões Centro-Oeste, Sul e Norte corresponderam, respectivamente, a $10,9 \%, 8,4 \%$ e $1,4 \%$. Os estados que acolheram o maior número de projetos enquadrados nesse Programa foram: São Paulo (42,5\%), Minas Gerais (10,5\%), Alagoas (7,0\%), Paraná (6,6\%), Goiás (6,3\%), Pernambuco (5,9\%), Rio de Janeiro (3,0\%), Paraíba (2,7\%), Mato Grosso (2,3\%) e Mato Grosso do Sul $(2,3 \%)$. Com a rublica recursos do PROÁLCOOL as participações percentuais desse enquadramento de projetos não foram muito diferentes da exposição anterior. Neste sentido, as participações das regiões Sudeste, Nordeste, Centro-Oeste, Sul e Norte corresponderam, respectivamente, a $51,5 \%, 24,4 \%, 12,8 \%, 10,1 \%$ e $1,2 \%$. Os estados que mais se destacaram na absorção de recursos do PROÁLCOOL foram: São Paulo (36,0\%), Minas Gerais $(10,3 \%)$, Alagoas $(8,1 \%)$, Paraná $(7,9 \%)$, Goiás $(7,2 \%)$, Pernambuco $(7,1 \%)$, Mato Grosso (3,2\%), Rio de Janeiro (3,0\%), Paraíba $(2,7 \%)$ e Mato Grosso do Sul $(2,5 \%)$.

Neste contexto, o número de destilarias autônomas no PROÁLCOOL (posição até fins de 1985) correspondeu a 59,0\% do número total de estabelecimentos, sendo sua capacidade de produção equivalente a $6.748,7$ milhões de litros/safra, que equivaleram a $54,2 \%$ da capacidade total de produção. Nota-se, portanto, a supremacia das destilarias autônomas frente às anexas (dados obtidos junto à CENAL).

Cabe destacar algumas colocações relativas à alteração geográfica da produção alcooleira nacional (Ricci et al., 1994). Primeiro, registrou-se o fortalecimento da produção alcooleira em regiões e estados já tradicionais nesse segmento produtivo, quais sejam: São Paulo e Rio de Janeiro (no Sudeste), Alagoas e Pernambuco (no Nordeste). Segundo, outros estados, dotados de uma razoável infra-estrutura agroindustrial canavieira, praticamente direcionada para a produção açucareira, expandiram-se também na área alcooleira, foram estes: Minas Gerais, Paraná, Paraíba e Rio Grande do Norte. Terceiro, estados como Goiás, Mato Grosso do Sul e Mato Grosso, sem nenhuma tradição anterior na agroindústria canavieira, passaram a ganhar destaque com a produção de álcool. Essas alterações geográficas evidenciam um maior direcionamento 
de empresários imitadores ao PROÁLCOOL, representando o processo de adaptação às inovações, fato este ressaltado por Schumpeter.

A Tabela 5, através de um quadro mais abrangente da evolução da capacidade de produção alcooleira no Brasil - onde destacam-se a capacidade anterior, a capacidade criada pelo PROÁLCOOL (até 1985) e a capacidade total -, contribui para avaliar melhor as colocações ressaltadas no parágrafo precedente.

Tabela 5 - Evolução da capacidade de produção de álcool no Brasil, 1974/1985 (em milhões de litros/safra).

\begin{tabular}{lrrrrrr}
\hline $\begin{array}{l}\text { Região } \\
\text { e } \\
\text { Estado }\end{array}$ & $\begin{array}{r}\text { Capacidade } \\
\text { anterior ao } \\
\text { PROÁLCOOL }\end{array}$ & $\%$ & $\begin{array}{r}\text { Capacidade } \\
\text { criada pelo } \\
\text { PROÁLCOOL }\end{array}$ & $\%$ & $\begin{array}{r}\text { Capacidade } \\
\text { total }\end{array}$ & $\%$ \\
\hline Norte & 5,4 & 1,3 & 153,5 & 1,3 & 158,9 & 1,3 \\
\hline RO & - & - & 61,9 & 0,5 & 61,9 & 0,5 \\
AM & - & - & 42,6 & 0,4 & 42,6 & 0,3 \\
PA & 5,4 & 1,3 & 31,0 & 0,3 & 36,8 & 0,3 \\
AC & - & - & 18,0 & 0,1 & 18,0 & 0,1 \\
\hline Nordeste & 111,9 & 26,8 & $2.278,8$ & 19,0 & $2.390,7$ & 19,2 \\
\hline MA & - & - & 91,0 & 0,7 & 91,0 & 0,7 \\
PI & 1,2 & 0,3 & 27,0 & 0,2 & 28,2 & 0,2 \\
CE & 7,2 & 1,7 & 55,5 & 0,5 & 62,7 & 0,5 \\
RN & - & - & 128,6 & 1,1 & 128,6 & 1,0 \\
PB & 24,7 & 5,9 & 260,8 & 2,2 & 285,5 & 2,3 \\
PE & 75,2 & 18,0 & 549,5 & 4,6 & 624,7 & 5,0 \\
AL & - & - & 821,2 & 6,8 & 821,2 & 6,6 \\
SE & - & - & 58,0 & 0,5 & 58,0 & 0,5 \\
BA & 3,6 & 0,9 & 287,2 & 2,4 & 290,8 & 2,4 \\
\hline Sudeste & 252,8 & 60,4 & $7.282,9$ & 60,5 & $7.535,7$ & 60,5 \\
\hline MG & 28,4 & 6,8 & 860,5 & 7,1 & 888,9 & 7,1 \\
ES & - & - & 189,5 & 1,6 & 189,5 & 1,5 \\
RJ & 29,0 & 6,9 & 260,8 & 2,2 & 289,8 & 2,3 \\
SP & 195,4 & 46,7 & $5.972,1$ & 49,6 & $6.167,5$ & 49,6 \\
\hline Sul & 48,3 & 11,5 & 870,8 & 7,2 & 919,1 & 7,4 \\
\hline PR & 42,5 & 10,1 & 762,2 & 6,3 & 804,7 & 6,5 \\
SC & 5,8 & 1,4 & 47,9 & 0,4 & 53,7 & 0,4 \\
RS & - & - & 60,7 & 0,5 & 60,7 & 0,5 \\
\hline Centro-Oeste & - & - & $1.450,4$ & 12,0 & $1.450,4$ & 11,6 \\
\hline MS & - & - & 279,9 & 2,3 & 279,9 & 2,2 \\
MT & - & - & 364,1 & 3,0 & 364,1 & 2,9 \\
GO & 418,4 & 100,0 & $12.036,4$ & 100,0 & $12.454,8$ & 100,0 \\
\hline Brasil & - & & & & 6,5 \\
\hline
\end{tabular}

Fonte: elaborada a partir de dados da CENAL. 
De fato, pode-se observar por meio da Tabela 5 que, em termos de valores absolutos, são confirmadas todas as colocações relativas à essa recente alteração geográfica da produção alcooleira nacional, apresentadas por Ricci et al. (1994). Entretanto, se se considerar as participações percentuais da capacidade de produção de álcool anterior ao PROÁLCOOL com a capacidade criada por este Programa, alguns pontos são merecedores de maiores esclarecimentos. É o caso, por exemplo, da região Nordeste, cuja capacidade de produção alcooleira passou de 111,9 milhões para 2.278,8 milhões de litros/safra; sendo que, em termos relativos, essa respectiva participação percentual no total nacional decresceu de $26,8 \%$ para $19,2 \%$. Nessa mesma linha de raciocínio seguem-se os casos dos estados da Paraíba, Pernambuco, Rio de Janeiro e Paraná, dentre os mais destacados. Ao contrário, os casos onde ocorreram tanto o aumento da capacidade de produção alcooleira como o aumento dessa participação percentual no total nacional verificaram-se para estados como o Rio Grande do Norte, Alagoas, Minas Gerais, São Paulo, Mato Grosso do Sul, Mato Grosso e Goiás, dentre os mais destacados. Portanto, dessa recente alteração geográfica da produção alcooleira nacional pode-se registrar que houve aumentos absolutos das produções em vários estados da União, não necessariamente seguidos de melhorias relativas da participação (\%) no total nacional.

Esses fatos relatados vem confirmar, por um lado, a posição hegemônica de alguns empresários tradicionais da agroindústria canavieira que efetivaram pioneiramente as novas combinações no início do PROÁLCOOL - conforme Schumpeter, o processo de difusão da inovação é eminentemente desigual. Esses empresários passaram a concentrar maiores esforços, durante a segunda fase desse Programa, na produção de álcool hidratado, com ênfase em destilarias autônomas (vide Gráfico 3). Por outro lado, diante da revigorada série de vantagens concedidas pelo Estado, subsidiando o uso do carro movido a álcool hidratado - a proporção de vendas de veículos movidos a álcool saltou de 28,5\% em 1980, para 96,0\% em 1985 (Comissão de Economia, Indústria e Comércio, 1991) - e estimulando a produção e consumo desse tipo de combustível (vide Gráfico 4), houve uma maior atração de grupos de empresários para essa área. Neste aspecto, a adesão de imitadores ao PROÁLCOOL foi significativa, seja de empresários da própria agroindústria canavieira que ainda estavam receosos quanto ao futuro desse Programa, seja de empresários sem nenhuma tradição nesta atividade. 
Gáfico 3 - Produção de álcool por tipo de destilaria - Brasil - 1979/80 a 1984/85.

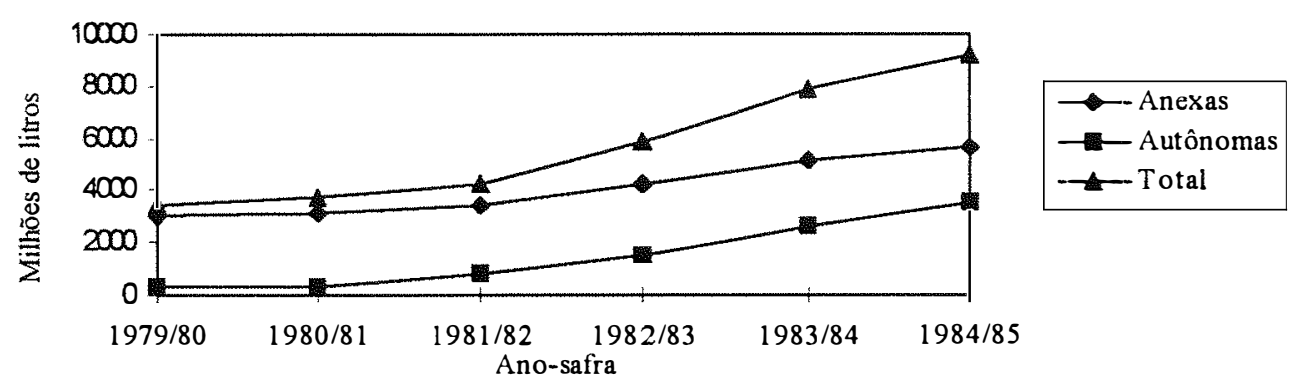

Fonte: IAA (dados primários).

Gráfico 4 - Produção e consumo de álcool anidro e hidratado no Brasil - 1979/80 a

1984/85.

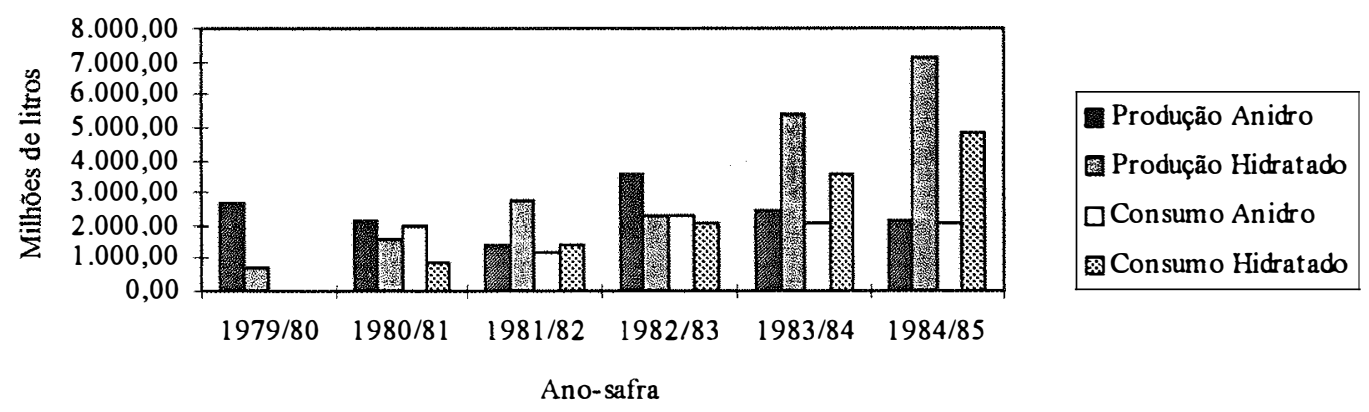

Fonte: IAA (dados primários).

Sem dúvida, os fatos ora relatados (subsídio ao carro movido a álcool hidratado, maior estímulo à produção de álcool, etc) deram novo ímpeto ao PROÁlCOOL. As Tabelas 6 e 7 confirmam, através de indicadores como a evolução do número de usinas e destilarias no Brasil e do destino da cana moída, o notável crescimento do Programa entre 1980-1985 (exceção feita para o número de destilarias no estado do Rio de Janeiro). Sobre a Tabela 6, assim como em 1975-1979, há evidências de oscilações no número de usinas de açúcar - com decréscimo em São Paulo e Rio de Janeiro, aumento do número de usinas em Minas Gerais e constância dessa monta em Alagoas e Pernambuco. Dessa vez, tal fato deve-se, mormente, ao ajuste estrutural feito pela agroindústria canavieira, crescentemente direcionada para a produção alcooleira, em detrimento da produção açucareira - que sofrera oscilações (Tabela 7 e Gráfico 5). 
Tabela 6 - Distribuição espacial das usinas de açúcar (U) e destilarias de álcool (D) no Brasil, segundo macrorregião (Centro-Sul; Norte/Nordeste) e principais estados produtores - 1980 a 1985.

\begin{tabular}{|c|c|c|c|c|c|c|c|c|c|c|c|c|c|c|c|c|}
\hline \multirow[b]{2}{*}{ Ano } & \multicolumn{2}{|c|}{ Brasil } & \multicolumn{2}{|c|}{ SP } & \multicolumn{2}{|c|}{$\mathrm{MG}$} & \multicolumn{2}{|c|}{$\mathrm{RJ}$} & \multicolumn{2}{|c|}{$\begin{array}{l}\text { Centro- } \\
\text { Sul }\end{array}$} & \multicolumn{2}{|c|}{$\mathrm{PE}$} & \multicolumn{2}{|c|}{$\mathrm{AL}$} & \multicolumn{2}{|c|}{$\begin{array}{c}\text { Nortel } \\
\text { Nordeste }\end{array}$} \\
\hline & $U$ & D & $\mathrm{U}$ & D & $\mathrm{U}$ & $\mathrm{D}$ & $U$ & $\mathrm{D}$ & $\mathrm{U}$ & $\mathrm{D}$ & $\mathrm{U}$ & $\mathrm{D}$ & $\mathrm{U}$ & $\mathrm{D}$ & $\mathrm{U}$ & $\mathrm{D}$ \\
\hline 1980 & 202 & 195 & 74 & $\overline{82}$ & 14 & 10 & 17 & 18 & 117 & 129 & 35 & 29 & 27 & 18 & 85 & 66 \\
\hline 1981 & 202 & 20 & 73 & 8 & 14 & 10 & 17 & 17 & 116 & 13 & 35 & 2 & 27 & 20 & 86 & 67 \\
\hline 1982 & 204 & 226 & 75 & 92 & 15 & 13 & 17 & 16 & 119 & 146 & 35 & 30 & 27 & 25 & 85 & 80 \\
\hline 1983 & 200 & 308 & 73 & 127 & 15 & 20 & 17 & 17 & 117 & 220 & 34 & 27 & 27 & 32 & 83 & 88 \\
\hline 1984 & 201 & 328 & 73 & 13 & 15 & 22 & 17 & 17 & 116 & 236 & 35 & 31 & 27 & 31 & 85 & 92 \\
\hline 1985 & 197 & 357 & 71 & 142 & 15 & 28 & 16 & 17 & 113 & 257 & 35 & 35 & 27 & 31 & 84 & 100 \\
\hline
\end{tabular}

Fonte: compilado do ANUÁRIO ESTATISTICO DO BRASIL (1981) - dados de 1980; ANUÁRIO ESTATÍSTICO DO BRASIL (1984) - dados de 1981-82; ANUÁRIO ESTATÍSTICO DO BRASIL (1986) - dados de 1983-84-85.

Tabela 7 - Destinação de cana moída no Brasil - 1977/78 a 1984/85 (em 1000 toneladas).

\begin{tabular}{ccccc}
\hline Ano-safra & Produção para álcool & $\%$ & Produção para açúcar & $\%$ \\
\hline $1977 / 78$ & 3.457 & 3,3 & 101.176 & 96,7 \\
$1978 / 79$ & 17.301 & 15,8 & 92.413 & 84,2 \\
$1979 / 80$ & 32.608 & 27,8 & 84.717 & 72,2 \\
$1980 / 81$ & 37.813 & 28,6 & 94.249 & 71,4 \\
$1981 / 82$ & 42.205 & 31,7 & 91.081 & 68,3 \\
$1982 / 83$ & 64.675 & 38,8 & 101.981 & 61,2 \\
$1983 / 84$ & 92.856 & 46,9 & 105.149 & 53,1 \\
$1984 / 85$ & 96.679 & 47,9 & 105.137 & 52,1 \\
\hline
\end{tabular}

Fonte: compilado do IAA - dados primários - dados de 1977/78 a 1980/81; ANUÁRIO ESTATÍSTICO DO BRASIL (1983, 1984, 1985 e 1986) - para, respectivamente: dados de 1981/82; dados de 1982/83; dados de 1983/84; e dados de 1984/85.

Gráfico 5 - Destinação de cana moída no Brasil - 1977/78 a 1984/85.

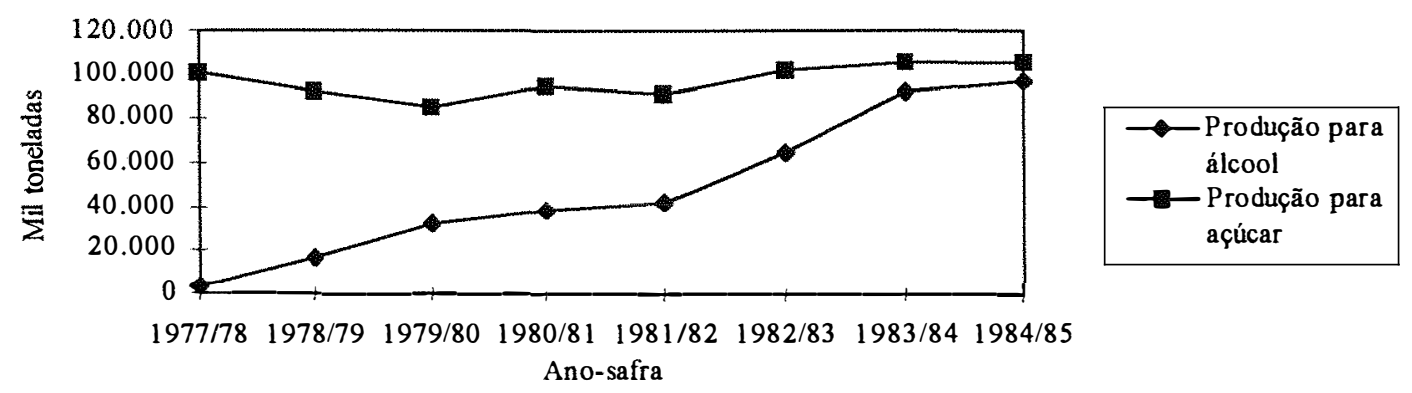

Fonte: IAA (dados primários) e ANUÁRIO ESTATÍSTICO DO BRASIL (1983-84-85-86).

A destinação da cana moída evidencia não somente o aumento dirigido para a produção de álcool como as oscilações da destinação de cana moída para a produção de açúcar. Sobre a produção nacional de açúcar, houve um decréscimo da produção entre 
1980/81 e 1981/82 (a produção passou de 8.100 mil toneladas para 7.935 mil toneladas), um crescimento de 1981/82 a 1983/84 (9.086 mil toneladas nessa última safra), e novamente um decréscimo de 1983/84 a 1985/86 (7.819 mil toneladas nessa última safra).

Simultâneo à ampliação do PROÁLCOOL durante 1980-1985, ocorreram novos desenvolvimentos tecnológicos que abriram perspectivas de mudanças na dinâmica econômica da agroindústria canavieira durante esse período. Segundo Ricci et al. (1994, p.31-32):

"As pesquisas sobre variedades de cana, realizadas pelo PLANALSUCAR e outros Institutos, começaram a ter seus resultados divulgados. A descoberta de novas variedades de cana, mais produtivas e adaptadas às condições de clima e solo das regiões produtoras representava a superação de um dos principais obstáculos para aumentar o rendimento da parte agrícola, um dos fatores responsáveis pelos baixos índices de produtividade de todo o setor.

A incorporação das novas variedades exigiu não só a introdução de novas tecnologias na agricultura, mas também novas formas de gerenciamento e controle da produção."

Macedo (1996) assinala a ocorrência de uma nova fase em termos de desenvolvimento tecnológico na agroindústria canavieira, basicamente a partir de 1981 82 (coincidindo com a fase de descenso no FUNAGRI) e que se prolongou até 1985, caracterizada pela busca de maior eficiência na conversão da sacarose para o produto final e nas reduções de custo de produção. Com efeito, em 1983 surgiu uma inovação substancial no método de pagamento da cana, deixando de ser por tonelada de cana (aspecto quantitativo) e passando a ser pelo teor de sacarose e pureza do caldo (aspecto qualitativo). Desse modo, priorizando a cana de melhor qualidade, os fornecedores teriam de se adequar tecnologicamente ao novo processo de pagamento. Esta mudança, segundo Eid (1996), além de constituir-se em um dos elementos explicativos do progresso técnico evidenciado na agroindústria canavieira, contribuiu também para o processo de redução do número de pequenos e médios fornecedores às expensas de um aumento na participação da cana própria, significando uma maior concentração da produção.

Segundo AGRIANUAL 96, a introdução no início dos anos 80 de uma variedade rica em açúcar e precoce, a NA 5679, coincidiu com a implantação do sistema de 
pagamento de cana pelo teor de sacarose. Antes, a lavoura canavieira do Centro-Sul mantinha-se praticamente limitada à variedade CB 41-76, mais produtiva, porém, com baixo teor de sacarose. Aquela nova variedade (NA 5679) logo difundiu-se, chegando a ocupar $27,72 \%$ da área total cultivada no Brasil nos idos de 1985. Entretanto, o avanço da doença do carvão obstaculizou a difusão da NA 5679, posto sua suscetibilidade à essa doença. Isto foi relativamente minimizado pela introdução das variedades SP 70-1143, SP 71-1406 e SP 71-6163, oriundas da COPERSUCAR (como ressaltado no capítulo 4).

Em recente levantamento estatístico, denominado Censo Varietal Quantitativo 1994, foi revelado que as variedades SP são responsáveis por cerca de $62,5 \%$ da área cultivada em estados como o Espírito Santo, Goiás, Mato Grosso, Mato Grosso do Sul, Minas Gerais, Paraná, Rio de Janeiro e São Paulo, representando aproximadamente 2,078 milhões de hectares cultivados com cana-de-açúcar (AGRIANUAL 96). Segundo Olalde (1993), a principal vantagem das variedades SP sobre os seus análogos reside no seu elevado teor de sacarose (para o caso da SP 71-1406 e SP 71-6163), e na boa produtividade agrícola, rusticidade e adaptação aos solos de baixa fertilidade (para o caso da SP 70-1143). Este fato assinala a maior preocupação com o programa de melhoramento genético da cana no Centro-Sul, principalmente em São Paulo - estado este que está sempre procurando adaptar variedades mais adequadas à sua lavoura canavieira.

Essas inovações, pagamento de cana pelo teor de sacarose e novas variedades de cana, bem como outras (por exemplo, a adaptação dos motores dos carros ao álcool hidratado), podem ser consideradas trajetórias tecnológicas pelas quais o PROÁLCOOL evoluiu. Neste tocante, foi a partir de interações de rotinas estabelecidas com experiências adquiridas nesse Programa, assim como em toda agroindústria canavieira, que foram obtidos alguns ganhos de eficiência.

De fato, os ganhos em termos de rendimento agrícola na agroindústria canavieira ultrapassaram a casa das 60 toneladas por hectare a partir de 1982 (Tabela 8). Entre 1977 e 1985, o rendimento agrícola elevou-se em 19,5\%, enquanto o rendimento industrial (segundo Magalhães et al., 1991), em litros por tonelada de cana-de-açúcar, subiu cerca de $23,2 \%$. Isto significou um incremento anual na produtividade da agroindústria canavieira de $2,25 \%$ e $2,64 \%$, respectivamente, para os segmentos agrícola e industrial. 
Tabela 8 - Área colhida, quantidade produzida de cana-de-açúcar e rendimento agrícola no Brasil - 1974 a 1985.

\begin{tabular}{cccc}
\hline Ano & $\begin{array}{c}\text { Area colhida } \\
\text { (mil ha })\end{array}$ & $\begin{array}{c}\text { Quantidade produzida } \\
\text { (mil toneladas) }\end{array}$ & $\begin{array}{c}\text { Rendimento agricola } \\
\text { (toneladas/ha) }\end{array}$ \\
\hline 1974 & 2.057 & 95.624 & 46,5 \\
1975 & 1.969 & 91.525 & 46,5 \\
1976 & 2.093 & 103.173 & 49,3 \\
1977 & 2.270 & 120.082 & 52,9 \\
1978 & 2.391 & 129.145 & 54,0 \\
1979 & 2.537 & 138.899 & 54,7 \\
1980 & 2.608 & 148.650 & 57,0 \\
1981 & 2.826 & 155.924 & 55,2 \\
1982 & 3.084 & 186.647 & 60,5 \\
1983 & 3.479 & 216.037 & 62,1 \\
1984 & 3.656 & 222.318 & 60,8 \\
1985 & 3.912 & 247.199 & 63,2 \\
\hline
\end{tabular}

Fonte: FIBGE (1990).

Segundo Nastari (1992) também ocorreu uma boa evolução do rendimento agroindustrial para o caso do açúcar, que para 1979-81 e 1985 apresentou valores da ordem de 5.349 e $6.649 \mathrm{~kg} / \mathrm{ha}$, respectivamente. Contudo, o crescimento da produtividade não foi uniforme no Brasil. A partir de dados do trabalho da Comissão de Economia, Indústria e Comércio (1991), observa-se que a taxa geométrica de crescimento do rendimento agroindustrial do álcool (litros/ha) - calculada pelo método dos mínimos quadrados - foi igual a 4,1\% a.a., isto em termos de Brasil e enfocando o período de 1979/80 a 1984-85. Neste mesmo raciocínio, se se considerar as macrorregiões Centro-Sul e Norte/Nordeste em separado, verificar-se-ão as seguintes taxas supracitadas: 4,0\% a.a. e 3,3\% a.a, respectivamente. Lima (1992) também assinala a diferença entre os rendimentos agroindustriais do açúcar para o Centro-Sul e Norte/Nordeste, sendo o primeiro mais eficiente que o segundo em aproximadamente $30 \%$.

Dessas informações sobressai-se a questão da diferenciação, agora em termos de produtividade, verificada entre as macrorregiões e estados representativos da agroindústria canavieira brasileira. Embora seja reconhecida essa diferença de produtividade, e também de custos de produção (Lima, 1992), esta constatação não pode ser considerada ad litteram, pois tanto no Norte/Nordeste como no Centro-Sul, ou mesmo em São Paulo, coexistem os produtores ditos mais modernos, com maior produtividade, e os mais atrasados, de baixa produtividade (Ricci et al., 1994; Eid, 1996). Em que pese este aspecto citado, o que deve ficar claro é o fato do atraso tecnológico e a 
conseqüente baixa produtividade realçarem-se com maior veemência na agroindústria canavieira do Norte/Nordeste, o que não impede, evidentemente, as ocorrências de "ilhas" de prosperidade no Norte/Nordeste e/ou "ilhas" de atraso em estados do CentroSul.

Segundo Melo \& Pelin (1984) e Villanova (1995), essas disparidades regionais existentes na agroindústria canavieira do Brasil não se limitam apenas aos entraves relacionados com os problemas edafo-climáticos e topográficos que existem no eixo nordestino, em especial, a qualidade do solo, as secas periódicas e a topografia relativamente acidentada que impede o uso mais intensivo da mecanização (verificada principalmente no norte de Alagoas e no sul de Pernambuco). Mas, sobretudo, porque nos estados do Centro-Sul, notadamente São Paulo, a lavoura canavieira apresenta tecnificação razoável em praticamente todas as fases da cultura, o mesmo não ocorrendo na maioria das unidades do Nordeste.

Essa tecnificação favorável deve-se, inclusive, à maior concentração técnicaeconômica em torno da agroindústria canavieira paulista, posto ser neste estado onde estão localizados os maiores centros de pesquisa (extinto PLANALSUCAR - atual Centro de Ciências Agrárias da Universidade Federal de São Carlos, Instituto Agronômico de Campinas, Centro Tecnológico da COPERSUCAR, IPT, etc) bem como as principais indústrias produtoras de máquinas e equipamentos direcionados para esse segmento produtivo (Dedini, Codistil, Zanini, etc) (Szmrecsányi, 1979; Ricci et al., 1994).

Ocorre que, com a evolução da agroindústria canavieira durante 1975-1995, período este caracterizado pela ocorrência da crise da economia açucareira e implementação do PROÁLCOOL, essas disparidades regionais irão apresentar um dinamismo próprio, mais acentuado principalmente a partir da terceira fase desse Programa (1986-1995), diante da tendência gradual de afastamento do Estado intervencionista e da crise do álcool enquanto alternativa energética. É quando um dos elementos importantes para a competitividade de um setor ou da economia, a capacitação tecnológica (Furtado, 1994), irá condicionar as perspectivas de malogro ou sucesso de uma usina ou destilaria. Assuntos estes a serem analisados na seção seguinte. 


\subsection{A AGROINDÚSTRIA CANAVIEIRA NO SUBPERÍODO 1986 a 1995: FASE DE "DESACELERAÇÃO E CRISE" DO PROÁLCOOL}

Dando seqüência às exposições anteriores, esta seção tem como propósito efetuar uma análise da evolução da agroindústria canavieira do Brasil referente ao subperíodo 1986-1995, caracterizado junto à literatura pertinente pela crise do PROÁLCOOL (Olalde, 1993; Villanova, 1995; Fernandes \& Coelho, 1996). Neste trabalho acrescentase o termo desaceleração ao termo crise, denotando a não abrupta passagem ocorrida no PROÁLCOOL no período 1980-1985, denominado de expansão "acelerada", ao período 1986-1995, denominado de "desaceleração e crise" desse Programa. Neste contexto, esta seção encontra-se estruturada de modo a ressaltar, inicialmente, uma avaliação geral dessa fase, mostrando pontos como o montante de recursos investidos no PROÁLCOOL, o arrefecimento relativo desse Programa (e suas razões principais) e as disparidades regionais de produtividade e custo. No item seguinte, procura-se reforçar fatos como a existência do paradigma tecnológico e da evolução desigual na agroindústria canavieira. Por fim, abordam-se temas como a situação financeira recente, a reconcentração do oligopólio e perspectivas para o setor. Novamente, esta análise encontra-se embasada no referencial teórico neoschumpeteriano e na abordagem neocorporatista.

\subsubsection{UMA AVALIAÇÃO GERAL}

Entre 1985 e 1990 foram investidos no Programa Nacional do Álcool cerca de US\$ 0,511 bilhão, dos quais $39 \%$ sendo capital público e $61 \%$ capital privado (Lopes, 1996). Após ter atingido seu auge em termos de recursos investidos em 1980-1984, este valor foi o menor já investido numa fase do PROÁLCOOL significando, respectivamente, $50,1 \%$ e $9,5 \%$ das quantias aplicadas na primeira e segunda fases desse Programa. Outrossim, confirmaram-se as tendências de diminuição percentual de inversões do capital público nesse Programa - de $75 \%$ passou para 56\%, atingindo 39\% - e de aumento percentual de inversões do capital privado - de $25 \%$ passou para $44 \%$, atingindo $61 \%$ - entre as 1aㅡ, 2 e e $3 \underline{a}$ fases do PROÁlCOOL.

Além da retirada gradual da participação dos investimentos públicos no PROÁLCOOL, antecipando uma tendência de afastamento do Estado intervencionista na 
agroindústria canavieira (Eid, 1996), a partir da safra 1986/87 começa a despontar a crise no abastecimento de álcool, uma tônica presente em grande parte da segunda fase do Programa. Conforme se pode constatar através da Tabela 9, o descompasso entre a produção e o consumo de álcool no Brasil não foi um fenômeno fortuito. Nas safras 1986/87, 87/88, 88/89, 90/91, e para os anos civis de 1993, 1994 e 1995, o consumo de álcool anidro foi maior do que sua produção. Já o consumo de álcool hidratado foi maior do que sua produção nas safras $1986 / 87,88 / 89,89 / 90$, e para o ano civil de 1994 . O consumo de álcool total (anidro + hidratado) superou sua produção nas safras 1986/87, 88/89 e 89/90, e para os anos civis de 1993, 1994 e 1995.

Tabela 9 - Produção e consumo de álcool anidro e hidratado no Brasil - 1985/86 a 1995 (em milhões de litros).

\begin{tabular}{crrrrrr}
\hline $\begin{array}{c}\text { Safra ou } \\
\text { ano }\end{array}$ & $\begin{array}{r}\text { Produção de } \\
\text { Anidro }\end{array}$ & $\begin{array}{r}\text { Produção de } \\
\text { Hidratado }\end{array}$ & $\begin{array}{r}\text { Produção } \\
\text { total }\end{array}$ & $\begin{array}{r}\text { Consumo } \\
\text { Anidro }\end{array}$ & $\begin{array}{r}\text { Consumo } \\
\text { Hidratado }\end{array}$ & $\begin{array}{r}\text { Consumo } \\
\text { total }\end{array}$ \\
\hline $1985 / 86$ & $3.200,0$ & $8.621,0$ & $11.821,0$ & $2.212,6$ & $6.761,7$ & $8.974,3$ \\
$1986 / 87$ & $2.163,1$ & $8.352,9$ & $10.516,0$ & $2.426,1$ & $8.760,3$ & $11.186,3$ \\
$1987 / 88$ & $1.983,7$ & $9.470,2$ & $11.453,9$ & $2.012,0$ & $8.983,1$ & $10.995,1$ \\
$1988 / 89$ & $1.725,9$ & $9.987,3$ & $11.713,3$ & $1.973,6$ & $10.128,3$ & $12.101,9$ \\
$1989 / 90$ & $1.451,7$ & $10.429,2$ & $11.880,9$ & $1.332,5$ & $10.614,8$ & $11.947,3$ \\
$1990 / 91$ & $1.288,5$ & $10.494,0$ & $11.782,6$ & $1.872,5$ & $9.899,8$ & $11.772,3$ \\
$1991 / 92$ & $1.986,8$ & $10.765,3$ & $12.752,1$ & $1.756,2$ & $10.031,2$ & $11.787,4$ \\
1992 & $1.986,8$ & $10.729,4$ & $12.716,2$ & $1.899,0$ & $9.630,7$ & $11.529,7$ \\
1993 & $2.216,4$ & $9.480,6$ & $11.697,0$ & $2.548,3$ & $9.404,4$ & $11.925,7$ \\
1994 & $2.522,6$ & $8.763,0$ & $11.285,6$ & $2.850,4$ & $9.665,1$ & $12.515,5$ \\
1995 & $2.869,1$ & $9.837,7$ & $12.706,8$ & $3.367,8$ & $9.722,0$ & $13.098,8$ \\
\hline
\end{tabular}

Fonte: compilado do IAA (dados primários) - produção de 1985/86; COPERSUCAR (1993) - produção de 1986/87 a 1991/92, e consumo de 1985/86 a 1991/92; DATAGRO (dados primários) - consumo de 1992 a 1995; e FNP Consultoria e Comércio/Associação das Indústrias de Açúcar e Álcool do Estado de São Paulo (AIAA), citado por AGRIANUAL 97 - produção de 1992 a 1995.

Este desequilíbrio entre a oferta e demanda de álcool combustível levou à necessidade de importação do produto a partir de 1989, inclusive na forma de metanol, para adições à gasolina ou ao próprio álcool hidratado (Parro, 1996). Entretanto, deve-se destacar que um dos objetivos do PROÁlCOOL é a economia de divisas (via redução da dependência externa do petróleo), e a importação de álcool contradiz esta proposição na medida em que se reduz a importação do petróleo e cria-se a necessidade de importação do álcool combustível e/ou de similares.

Valendo-se ainda das informações contidas na Tabela 9, frisa-se que a participação do álcool anidro no total produzido e consumido, respectivamente, $18 \%$ e $19 \%$, em média, foi consideravelmente menor em comparação com o álcool hidratado - 
cujas participações no total produzido e consumido foram de, respectivamente, $82 \%$ e $81 \%$, em média. Este fato vem corroborar, também para a terceira fase do PROÁLCOOL, a orientação mais pragmática da estratégia tomada a partir da segunda fase, assentada principalmente na produção de álcool hidratado. Outro aspecto notado na Tabela 9 são as consideráveis oscilações das produções de álcool hidratado, anidro e da soma destes dois.

Outro indicador de redução do ímpeto do PROÁLCOOL pode ser constatado através da variação da área colhida com cana-de-açúcar. Neste sentido, na fase de expansão "moderada", a taxa geométrica de crescimento da área colhida foi equivalente a $6,6 \%$ a.a., ocorrida basicamente em regiões tradicionais. $\mathrm{Na}$ fase de expansão "acelerada", na qual foram usadas inclusive novas plantações de cana-de-açúcar em regiões sem tradição nesse cultivo, verificou-se uma maior taxa geométrica de crescimento da área colhida com cana-de-açúcar, cerca de 8,7\% a.a.. Em contraste, observa-se um inexpressivo crescimento, cerca de 0,6\% a.a., para a fase de "desaceleração e crise" desse Programa.

Enquanto pelo lado do Estado os recursos públicos investidos no PROÁLCOOL diminuíam paulatinamente, pelo lado do produtor de álcool as instabilidades na produção contribuíam para sérios desequilíbrios entre a oferta e demanda por este produto. Se, a formação de expectativas está vinculada à vigência de um estado de confiança quanto ao futuro (Dosi, 1984), pode-se aferir que tais fatores teriam necessariamente de refletir nos comportamentos de agentes econômicos de suma importância para o PROÁLCOOL: a indústria automobilística e o consumidor de álcool combustível.

A Tabela 10 mostra como foi a evolução da proporção de venda de veículos a álcool no País durante toda a década de 80 e para alguns anos da década de 90 . Nota-se que, após evoluir de $28,5 \%$ para $88,5 \%$ nos primeiros quatro anos da década de 80 , a venda de carro a álcool ultrapassou a casa dos $90 \%$ durante os quatro anos seguintes. Porém, a diminuição dessa participação no mercado ocorreria na década seguinte, já a partir do ano de 1990. Dessa forma, enquanto em 1994 o veículo a álcool representou $12,2 \%$ do volume total das vendas de carros produzidos internamente, em 1995 a participação desse item chegou a ser de apenas 3,6\%. Face a esta reação do mercado, dada pela combinação da diminuição da produção de veículos a álcool e redirecionamento do consumidor para o veículo a gasolina, a crise do PROÁLCOOL 
ganhou proporções que certamente comprometem todo o arranjo institucional elaborado para o êxito deste Programa. Isto, não só no curto-prazo, como também no longo-prazo.

Tabela 10 - Proporção de vendas de veículos a álcool sobre o total de veículos - Brasil (1980-1990 e 1994-1995).

\begin{tabular}{cc}
\hline Ano & \% de veículos a álcool \\
\hline 1980 & 28,5 \\
1981 & 28,7 \\
1982 & 38,1 \\
1983 & 88,5 \\
1984 & 94,6 \\
1985 & 96,0 \\
1986 & 92,1 \\
1987 & 94,4 \\
1988 & 88,4 \\
1989 & 52,5 \\
1990 & 11,6 \\
1994 & 12,2 \\
1995 & 3,5 \\
\hline
\end{tabular}

Fonte: compilado da ANFAVEA, citado por Comissão de Economia, Indústria e Comércio (1991, p.51) dados de 1980-1990; "VENDAS de automóveis a álcool despencam 76\%" (Folha de São Paulo, 1995) dados de 1994 e 1995.

Esta cronologia de notória perda do dinamismo do PROÁLCOOL durante sua terceira fase, após duas fases anteriores de crescimento, remete o nosso trabalho à formulação schumpeteriana de ciclos econômicos. Com efeito, associando essas três fases do PROÁLCOOL com as fases do ciclo econômico de Schumpeter, pode-se observar relações análogas entre ambas (conforme visto no item 2.1, não obstante as idéias de Schumpeter terem sido elaboradas para explicar as flutuações de uma economia, é possível adaptar algumas de suas argumentações para explicar as flutuações de um setor específico dessa economia, como o da agroindústria canavieira). A rigor, os ciclos na economia, segundo Schumpeter, possuem quatro fases: recuperação, prosperidade, recessão e depressão. A fase de expansão "moderada" do PROÁLCOOL (1975-1979) apresentou sinais de recuperação da economia canavieira; a expansão "acelerada" (19801985) foi o momento de auge nesse setor; enquanto a fase de "desaceleração e crise" (1986-1995) carrega sinais evidentes de retração econômica.

Mas, diante desse atual cenário, por que razão teria o PROÁLCOOL entrado numa fase tão crítica, se sua "orquestração" de interesses, outrora bem sucedida, aparentava-se razoavelmente consolidada? Assim como a indagação, esta resposta passa pela relação entre "gargalo" tecnológico e "orquestração" de interesses. Faz-se necessário realçar que o "gargalo", oriundo da crise do petróleo, e que foi vital para a criação e posterior expansão do PROÁLCOOL, desapareceu. Assim sendo, desapareceu a 
justificativa diante da população brasileira para manter o corporatismo em torno desse Programa.

A propósito, o Gráfico 6 mostra a evolução dos preços da gasolina, que apresentou uma tendência decrescente nos anos 90 , e dos preços internacionais do açúcar, que vem apresentando algumas "bolhas de euforia" (1980 e 1990) intercaladas com fases de preços baixos. ${ }^{15}$

Gráfico 6 - Preços médios do açúcar bruto (Bolsa de Nova York, em centavos de US\$/Libra-peso) e da gasolina (FOB, Roterdã, US\$/bb) - 1976-1994.

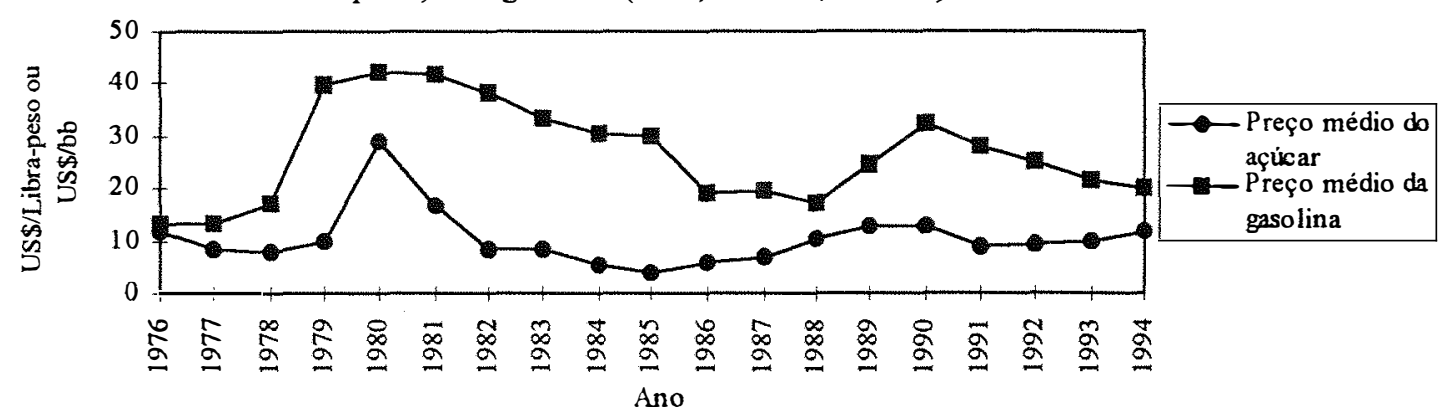

Fonte: Para o açúcar: World Economic and Financial Surveys - Primary Commodities Market Developments and Outlook (1986), citado por Abbott (1990, p.38) - dados de 1976 a 1981; e AGRIANUAL 96 - dados de 1982 a 1994. Para a gasolina: Carvalho (1996).

Sobre a "orquestração" de interesses no âmbito do Estado, existem três frentes a serem discutidas a esse respeito: a posição da PETROBRÁS, a extinção de órgãos públicos ligados à agroindústria canavieira e a alteração do próprio perfil do Estado.

De acordo com o artigo "PROÁLCOOL gera R\$1,3 bi de prejuízo por ano e mantém 1,3 milhão de empregos" (Folha de São Paulo, 1996), uma das estratégias que o Estado tem feito para manter o PROÁLCOOL é obrigar a PETROBRÁS a comprar o álcool combustível a um preço maior do que é estabelecido para venda às distribuidoras e postos de serviços. A diferença, que inclui o prejuízo dessa operação e os custos de transporte, fica a cargo dessa empresa estatal por determinação superior do seu acionista

\footnotetext{
${ }^{15}$ Com a recuperação dos preços internacionais do açúcar durante a primeira metade da década de 90 , causado por fatores como a instabilidade das ofertas de açúcar de países como a Índia, Tailândia e Cuba, as exportações brasileiras deste produto voltaram a crescer, passando de 1.300 mil toneladas métricas em 1990/91 para 5.200 mil toneladas métricas em 1995/96. Isto concorreu para favorecer a produção de açúcar, dada a capacidade flexível de produção, comprometendo ainda mais a oferta de álcool no País. Maiores considerações sobre o mercado externo açucareiro, ver: Shikida (1990), Nastari (1992), López (1992), World sugar outlook (1994), Burnquist \& Bacchi (1996) e Burnquist (1996).
} 
majoritário, ou seja, o Estado. Ademais, com a elevação do consumo de álcool combustivel e a conseqüente diminuição do consumo de gasolina na segunda metade da década de 80, a PETROBRÁS, dado o caráter relativamente rígido do perfil de refino, viu-se obrigada a exportar os excedentes de gasolina a preços não convenientes (Belik, 1992). Isto ocorreu porque os preços internacionais deste produto ficaram relativamente baixos após a oferta excessiva verificada a partir de meados da década de 80 (Olalde, 1993 ${ }^{16}$, sendo esses preços de exportação da gasolina inferiores, inclusive, aos preços de importação do álcool, necessário para atender plenamente à demanda nacional (Abreu, 1996). Como o Estado deveria cobrir esta diferença de custo através da Conta-Álcool dada pela equação do preço de venda do álcool (anidro + hidratado) ao consumidor menos o custo final do álcool combustível (Belik, 1992) - e, sendo os recursos gerados insuficientes para cobrir tais despesas, o que ocorreu novamente foi a transferência do ônus financeiro dessa atividade para a PETROBRÁS (Rennó, 1995; Abreu, 1996). "Em abril de 1995, o déficit acumulado atingiu mais de 2 bilhões de dólares, exclusivamente devido à Conta-Álcool, e correspondendo a quase metade do total de investimentos da PETROBRÁS" (Abreu, 1996, p.25).

Além do subsídio dado ao usineiro e da gravidade da Conta-Álcool, que representam perda de receita dessa estatal e dívida para o Estado (Rennó, 1995), existe uma outra razão que motiva os interesses da PETROBRÁS contra o PROÁLCOOL. Trata-se do aumento da produção nacional de petróleo e a conseqüente diminuição da dependência externa desse produto. De fato, com a intensificação da exploração petrolífera no País a partir dos "choques" do petróleo, acrescida da descoberta de importantes reservas na Bacia de Campos, a produção nacional aumentou de 165 mil barris/dia na segunda metade da década de 70, para mais de $600 \mathrm{mil}$ barris/dia no início da década de 90 (Olalde, 1993). Segundo o artigo "PROÁLCOOL gera R\$1,3 bi de prejuízo por ano e mantém 1,3 milhão de empregos" (Folha de São Paulo, 1996, p.1-10), vê-se que:

\footnotetext{
"A Associação dos Engenheiros da PETROBRÁS (AEPET) é contra a reativação do PROÁLCOOL, e a própria empresa, embora não se manifeste oficialmente, preferiria cuidar
}

\footnotetext{
${ }^{16}$ Os investimentos em exploração petrolifera efetuados por vários países, sobretudo diante dos dois "choques" do petróleo, ampliaram as reservas de petróleo e viabilizaram as explorações de maior custo de extração, sinalizando para os anos 90 um panorama muito menos catastrófico do que fôra previsto nos anos 70 (Olalde, 1993).
} 
apenas do que entende: o petróleo e seus derivados - gasolina, diesel, querosene etc." (grifo nosso)

Quanto aos outros órgãos públicos ligados à agroindústria canavieira sabe-se, com base em Ramos \& Belik (1989), que o PROÁLCOOL contribuiu para que o Instituto do Açúcar e do Álcool (IAA) parcialmente deixasse de ter poder como instituição reguladora do setor, haja vista que coube à Comissão Executiva Nacional do Álcool (CENAL) o suporte técnico e administrativo ao Programa. Em fins da década de 80 o que se observou foi que "até mesmo a determinação dos preços e das cotas de produção foi deslocada (...) do IAA, cabendo os preços à SEAP (Secretaria Especial de Abastecimento e Preços) e as cotas recebendo influências diversas que passam pela CENAL (...)", entre outros órgãos do governo - Ministério de Minas e Energia, etc (Ramos \& Belik, 1989, p.211).

Ademais, alguns órgãos representantes dos interesses da agroindústria canavieira, como a Cooperativa Fluminense dos Produtores de Açúcar e Álcool (COPERFLU) criticavam, já em 1980, o hiperdimensionamento do aparelho administrativo ligado à agroindústria canavieira, solicitando medidas como a privatização e a liberalização das atividades controladas pelo IAA. Mesmo no Nordeste, onde a pressão política dos usineiros no aparelho do IAA era maior, sobretudo para manter os privilégios locais, se encontravam desarmadas as principais esferas de decisão deste órgão (Ramos \& Belik, 1989).

De acordo com Ricci et al. (1994), o governo Collor tinha como intenção implantar uma política neoliberal, propondo uma maior racionalização da máquina do Estado. Tal política apontava, entre outras coisas, para o fim dos incentivos e subsídios governamentais, aumento das privatizações, extinção e/ou fusão de várias instituições públicas. Diante desse cenário, agravado pelo esvaziamento e pressão política sobre o IAA, os funcionários desta Instituição, interessados na manutenção de suas funções, viram-se subjugados pelo interesse maior do governo. Foi neste contexto político que o IAA, através da Medida Provisória no 151, de 15/03/1990, foi extinto, passando, posteriormente, suas atribuições para a Secretaria de Desenvolvimento Regional (SDR).

Embora a extinção do IAA já fizesse parte dos interesses de alguns empresários da agroindústria canavieira, em especial os do Centro-Sul, este órgão constituía ainda em 
uma "trincheira de luta" dos produtores nordestinos (Ramos \& Belik, 1989). Desse modo, tal medida poderia contribuir para acirrar o desequilíbrio de forças nas relações entre os usineiros do Norte/Nordeste vis-à-vis os do Centro-Sul. Entretanto, a extinção do IAA teve mais efeito como indicador de uma tendência gradual de afastamento do Estado na economia canavieira, feita com a privatização das exportações do açúcar, antes de exclusividade do IAA, e com o desmantelamento da pesquisa agronômica nessa área, via remanejamento dos funcionários da PLANALSUCAR para algumas universidades federais.

Não obstante a extinção do IAA, continuaram existindo algumas práticas reguladoras como a fixação de quotas de produção, o planejamento de safra, a permissão para implantação de novas destilarias e usinas ficava à mercê de autorização da SDR, e foram mantidos os subsídios para os produtores do Norte/Nordeste - sob a forma de taxa de equalização de custo (Ricci et al., 1994). Sob este ponto, Lima (1988b) argumenta que os usineiros, especificamente do Nordeste, continuaram desfrutando de alguns privilégios junto ao Estado, mesmo após a extinção do IAA, porque historicamente as elites nordestinas têm mantido estreitos vínculos com o aparelho de Estado, via representação política de seus governadores, senadores, deputados, ministros e de membros ocupando postos-chaves da burocracia federal.

O fato é que com a extinção de um órgão público como o IAA, que mesmo esvaziado em algumas de suas funções ainda era melhor aparelhado que a CENAL para o planejamento do setor alcooleiro (Moreira, E. 1989), e que também implicava na extinção automática de outro importante órgão, voltado para a pesquisa agronômica na lavoura canavieira - o PLANALSUCAR -, pôde o PROÁLCOOL perder duas instituições que poderiam, quiçá, contribuir para criar condições de um desenvolvimento mais equilibrado do setor.

Esta tônica de restruturação do Estado está intimamente ligada à análise do seu perfil, não só diante da agroindústria canavieira como de toda a economia. Portanto, o que se tem observado no Brasil a partir dos anos 90 é um Estado revestido de interesse neoliberal, mas também afetado por uma séria crise fiscal que, segundo Goldin \& Rezende (1993), tem forçado a contenção do crescimento do PROÁLCOOL. Para Quadros (1995, p.22), "não há como dissociar o destino do PROÁLCOOL dos resultados do processo de reorganização do Estado." 
Apesar de serem mantidos alguns privilégios para a agroindústria canavieira, a contenção dos gastos públicos tem afetado diretamente os mecanismos de transferência de recursos do Estado para o setor. Foi assim, por exemplo, com a diminuição gradual de recursos públicos aplicados no PROÁLCOOL, e com a incidência de correção monetária integral nos financiamentos industriais e rurais desse Programa (Belik, 1992).

Em relatório apresentado à Câmara dos Deputados, através da subcomissão especial para exame da situação do setor sucroalcooleiro brasileiro, atesta-se que o principal motivo para a desregulamentação da agroindústria canavieira "(...) é a constatação de que o governo vem sendo absolutamente ineficiente em seu papel de planejador e regulador desta atividade" (Comissão de Economia, Indústria e Comércio, 1991, p.19). Dentre as principais distorções do processo de intervenção, foram destacadas: a política de preços defasados em relação aos custos médios de produção; inadequação do sistema de comercialização de álcool com o sistema de produção e a manutenção de estoques de segurança; a falência do fornecedor de cana autônomo; a miséria do trabalhador rural e as distorções da relação entre o capital e o trabalho; o agravamento das relações entre a PETROBRÁS e os produtores de álcool; distorções do monopólio estatal na exportação de açúcar; e, aproveitamento insatisfatório de subprodutos.

Esse posicionamento do Estado também provocou efeitos em outros interesses do PROÁLCOOL. No âmbito da indústria de máquinas e equipamentos para a agroindústria canavieira a situação generalizada de escassez de financiamentos interrompeu alguns processos de implantação ou ampliação de destilarias, provocando incertezas naquela indústria decorrente da falta de encomendas (Belik, 1992). Para Parro (1996), a falta de confiança na garantia do abastecimento de álcool, o aumento gradativo do preço do álcool hidratado em relação ao da gasolina - a relação entre o preço do álcool e o da gasolina elevou-se para 64,5\% em 1979, e para $80 \%$ em meados da década de 90 - e a diminuição do estímulo de menor IPI, fizeram com que as vendas de veículos a álcool caíssem. Destarte, não coube outra saída à indústria automobilística senão diminuir a produção de veículos a álcool e aumentar a produção de veículos a gasolina, redirecionando, assim, suas trajetórias tecnológicas.

Embora haja divergências de posicionamentos dos empresários da agroindústria canavieira do Norte/Nordeste e Centro-Sul, existem também posições concordantes. 
Neste caso, os representantes dos produtores de açúcar e álcool são unânimes em apontar a causa principal das dificuldades pelas quais passa a agroindústria canavieira nacional, qual seja: a política de preços defasados em relação aos custos médios imposta pelo Estado a partir de 1985 (Comissão de Economia, Indústria e Comércio, 1991). Para COPERSUCAR (1993, p.6), o ano de 1985 "era o início de uma situação (...) na qual o governo utiliza-se de tarifas públicas arbitrárias e artificiais na tentativa de controlar os índices inflacionários (...). O álcool, por submeter-se ao controle governamental de preços, sofre as mesmas conseqüiencias (...)."

Em decorrência dessa política de preços, de acordo com o presidente da SOPRAL, João Francisco Soares, o prejuízo compulsório imputado pelo Estado à agroindústria canavieira na região Centro-Sul chegou a corresponder a US\$ 4,17 bilhões (posição de fevereiro de 1991), gerando efeitos iníquos à economia canavieira, como a acelerada descapitalização, a incapacidade de aplicação de tratos culturais adequados e o elevado endividamento. Para o presidente da Cooperativa Regional dos Produtores de Açúcar e Álcool do Estado de Alagoas Ltda., João Tenório, com essa política de preços defasados a agroindústria canavieira, juntamente com os outros setores públicos e privados que tiveram os seus preços e tarifas administrados, foram colocados todos numa "vala" comum (Comissão de Economia, Indústria e Comércio, 1991).

Pela Tabela 11 constata-se que a média dos preços pagos aos produtores de canade-açúcar (em São Paulo), na década de 70, foi maior do que em períodos posteriores. A tendência observada é de queda de preços, onde de fevereiro/95 à fevereiro/96 ocorreu uma média de $\mathrm{R} \$ 13,25$ (em valores de fevereiro de 1996) paga por tonelada de cana.

Tabela 11 - Preços pagos ao produtor de cana-de-açúcar para o estado de São Paulo (em $\mathrm{R} \$$ /tonelada) - preços deflacionados - valores de fevereiro de 1996.

\begin{tabular}{c|c|c|c}
\hline Período & \multicolumn{3}{|c}{$\mathrm{R} \$ / \mathrm{t}$ (deflacionado) } \\
\cline { 2 - 4 } & Mínimo & Média & Máximo \\
\hline Década de 70 & 21,83 & 32,96 & 37,14 \\
Década de 80 & 13,53 & 24,95 & 37,48 \\
$1990-96$ & 11,89 & 14,55 & 18,24 \\
$1987-96$ & 11,89 & 15,72 & 23,95 \\
fev/95 a fev/96 & 12,54 & 13,25 & 14,33 \\
\hline
\end{tabular}
Fonte: PREÇOS AGRICOLAS (1996, p.42).

Os Gráficos a seguir retratam a tendência decrescente dos preços pagos aos produtores de cana-de-açúcar, açúcar e álcool do Norte/Nordeste e Centro-Sul. A 
diferença de preços entre essas macrorregiões se deve ao subsídio de equalização de custos, onde "(...) a diferença de custos entre os produtores do Norte/Nordeste e CentroSul seria coberto por um subsidio pago pelo governo" (Lima, 1992, p. 109).

Gráfico 7 - Preço da cana-de-açúcar pago aos produtores no Centro-Sul e Norte/Nordeste - 1978/1995.

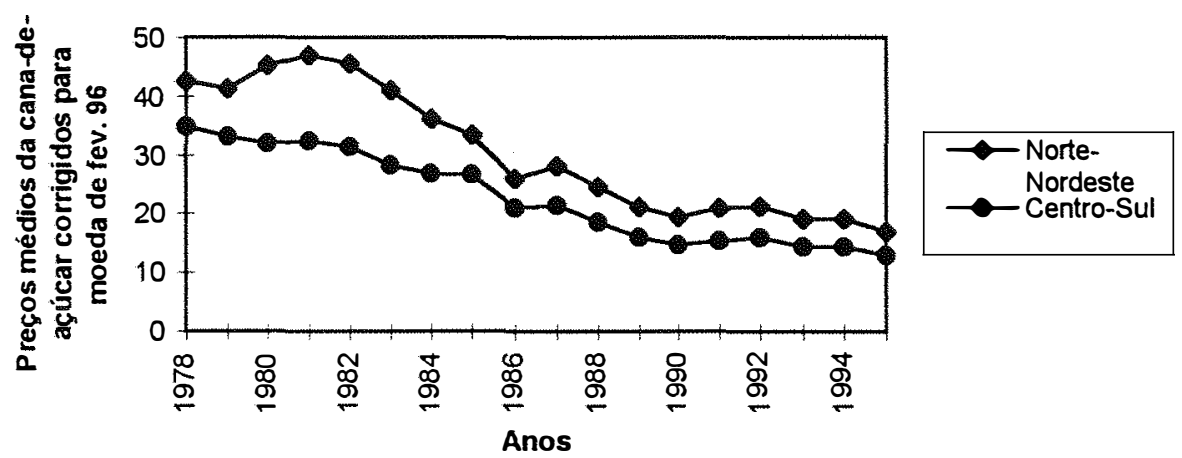

Fonte: Elaborado a partir de dados da DATAGRO.

Obs.: preço da cana (em $\mathrm{R} \$ \mathrm{t}$ ) no campo mais transporte para todos os estados do Norte/Nordeste e do Centro-Sul, exceto RJ.

Gráfico 8 - Preço do açúcar pago aos produtores no Centro-Sul e Norte/Nordeste - 1978/1995.

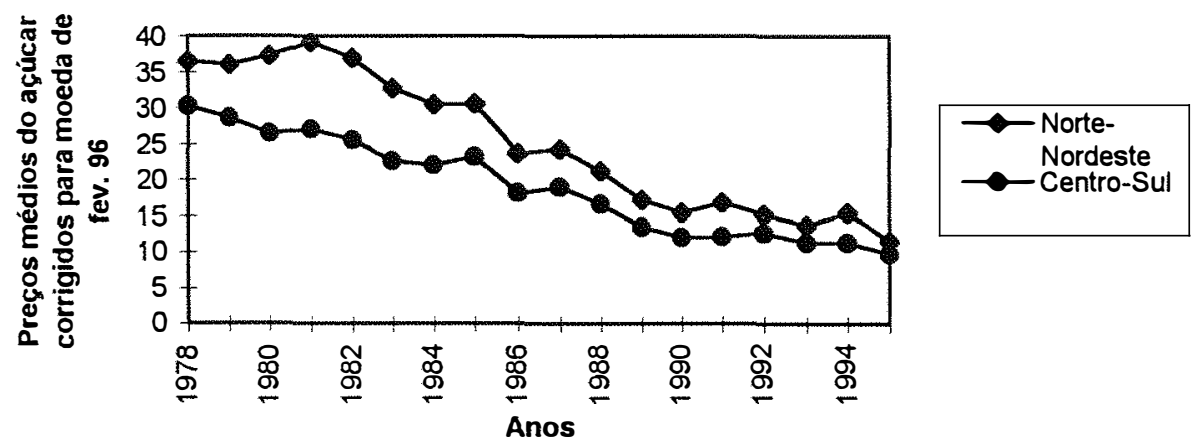

Fonte: Elaborado a partir de dados da DATAGRO.

Obs.: preço do açúcar cristal standard (em R\$/saca de $50 \mathrm{~kg}$ ) do valor do produto industrializado no Centro-Sul; e no Norte/Nordeste preço do valor do produto industrializado + taxa de equivalência do açúcar cristal standard. 
Gráfico 9 - Preço do álcool pago aos produtores no Centro-Sul e Norte/Nordeste - 1978/1995.

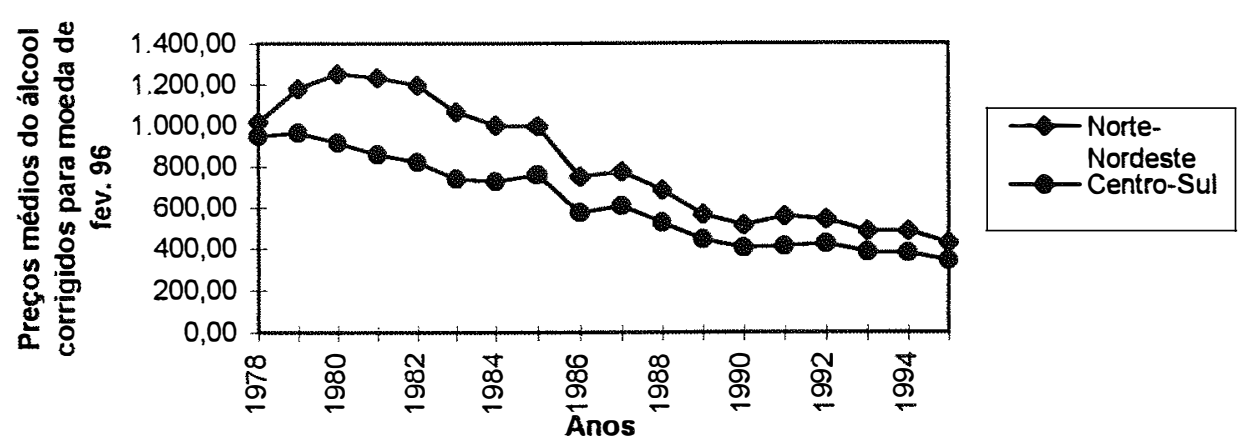

Fonte: Elaborado a partir de dados da DATAGRO.

Obs.: preço do álcool valor de paridade p/anidro (em $\mathrm{R} \$ /$ metro cúbico) no Centro-Sul; e no Norte/Nordeste preço do álcool valor de paridade p/anidro + taxa de equalização.

Os Gráficos 7, 8, e 9, juntamente com os dados da Tabela 11, corroboram a tendência decrescente dos preços pagos seja para o produtor da cana-de-açúcar, açúcar ou álcool. Desponta, ainda, outra tendência nos Gráficos em apreço, isto é, a diminuição da diferença entre os preços pagos aos produtores do Norte/Nordeste frente aos do Centro-Sul, visto através do maior distanciamento entre as linhas dos preços pagos para cada macrorregião entre 1978 a 1986, e do encurtamento dessa distância a partir de 1986. De acordo com esta observação, continuou vigorando o subsídio de equalização de custos favorável à agroindústria canavieira norte/nordestina, mantido através de uma articulada junção de interesses do capital agroindustrial canavieiro local com políticos do Nordeste (Lima, 1988b). Por outro lado, forçado principalmente pela crise fiscal, e contando com o apoio de usineiros do Centro-Sul, a diferença de preços pagos entre as duas macrorregiões diminuiu sensivelmente a partir de 1986.

\subsubsection{A EVOLUÇÃO DIFERENCIADA E O PARADIGMA TECNOLÓGICO NA AGROINDÚSTRIA CANAVIEIRA}

No âmbito da agroindústria canavieira, a crise do PROÁLCOOL confirmou, por um lado, a existência de produtores que adotaram um outro paradigma (tecnológico) como modelo de sobrevivência. Por outro lado, realçou com maior veemência a evolução diferenciada existente na agroindústria canavieira do Brasil. 
Quanto a este último aspecto supracitado, a crise do PROÁLCOOL contribuiu para acirrar a antiga rivalidade entre o Centro-Sul e o Norte/Nordeste. Destarte, a representatividade dos usineiros com o PROÁLCOOL foi reforçada, no Centro-Sul, com a fundação em 1992 da Associação das Indústrias de Açúcar e Álcool do Estado de São Paulo - AIAA. "A AIAA foi montada a sombra da COPERSUCAR, com o objetivo explícito de ser o 'braço político' da mesma. No entanto, a associação pretende ser independente o suficiente para ampliar suas alianças (...)" (Belik, 1992, p.173). No Norte/Nordeste, a capacidade de organização dos usineiros não procurou criar uma instituição para defender ainda mais seus interesses, ao contrário, voltou-se para uma ação combinada com sua representatividade política, procurando, com isso, assegurar a sobrevivência e a expansão do capital sucroalcooleiro nordestino, de interesse de ambas as classes em apreço (Lima, 1988b).

Para a COPERSUCAR, nesta redefinição do papel do Estado e diante da crise do PROÁLCOOL, o ônus do ajuste a ser feito no setor deve ser pago pelos usineiros do Nordeste (Belik, 1992), posto o seu atraso tecnológico e a conseqüente baixa produtividade do setor. Por outro lado, as performances política e organizacional dos usineiros nordestinos e de sua representação política salientam amiúde a necessidade de manutenção de privilégios locais, como a taxa de equalização de custos e a reserva de mercado, sob a pena de grandes perdas em termos de geração de emprego e renda (Lima, 1988a e 1988b).

O subsídio de equalização de custos é uma das grandes provas de que existe uma situação (realidade) diferenciada na agroindústria canavieira do Brasil. Segundo Lima (1988a, p.440), "cedendo a pressão dos usineiros nordestinos, o IAA estabeleceu, a nivel de produtor, um sistema de subsídios, chamados de 'equalização de custos', com o objetivo de proteger o ramo menos eficiente da indústria, ou seja, o nordestino." De acordo com Lima (1988b), o subsídio de equalização de custos transferiu, no período 1974/84, cerca de US\$2,2 bilhões para os usineiros do Nordeste.

Essas diferenças regionais de custos podem ser melhor retratadas através de dados da Fundação Getúlio Vargas (FGV - Rio de Janeiro). A Tabela 12 apresenta a participação relativa dos itens de custos de produção para a cana-de-açúcar em 5 estados tradicionais. Os dados contidos nessa Tabela permitem separar a agroindústria canavieira em mais capital-intensiva nos estados do Centro-Sul e mais trabalho-intensiva nos estados 
do Nordeste. Além disto, mostra o custo de oportunidade da terra relativamente mais baixo em Alagoas e Pernambuco, o que serve de justificativa para a continuidade da lavoura canavieira nestes estados, fato este preconizado pelo lobby da agroindústria local.

Tabela 12 - Participação relativa dos itens custos de produção para a cana-de-açúcar em SP, MG, RJ, AL e PE - em percentagens - (safras de 1982/83 a 1986/87).

\begin{tabular}{|c|c|c|c|c|c|c|c|c|c|}
\hline $\begin{array}{l}\text { Esta- } \\
\text { do }\end{array}$ & Safras & $\begin{array}{c}\text { Mão-de- } \\
\text { obra }\end{array}$ & $\begin{array}{l}\text { Insu- } \\
\text { mos }\end{array}$ & $\begin{array}{l}\text { Máquinas e } \\
\text { equipamen } \\
\text { tos }\end{array}$ & $\begin{array}{l}\text { Custos } \\
\text { financei- } \\
\text { ros }\end{array}$ & $\begin{array}{l}\text { Renda } \\
\text { da terra }\end{array}$ & $\begin{array}{l}\text { Despesas } \\
\text { adminis- } \\
\text { trativas }\end{array}$ & $\begin{array}{c}\text { Custo de } \\
\text { circulação } \\
\text { (transporte) }\end{array}$ & $\begin{array}{c}\text { Demais } \\
\text { itens }\end{array}$ \\
\hline \multirow{5}{*}{$\mathrm{SP}$} & $82 / 83$ & 22,43 & 17,34 & 13,61 & 9,19 & 11,64 & 4,75 & 12,64 & 8,40 \\
\hline & $83 / 84$ & 26,40 & 17,93 & 11,54 & 6,66 & 11,88 & 4,55 & 13,86 & 7,18 \\
\hline & $84 / 85$ & 23,22 & 19,08 & 9,60 & 5,77 & 17,91 & 4,74 & 10,96 & 8,72 \\
\hline & $85 / 86$ & 28,46 & 17,11 & 7,56 & 5,97 & 14,07 & 4,49 & 12,20 & 10,14 \\
\hline & $86 / 87$ & 23,94 & 24,61 & 8,04 & 6,74 & 10,94 & 4,15 & 13,46 & 8,12 \\
\hline \multirow{5}{*}{ MG } & $82 / 83$ & 22,78 & 19,62 & 10,95 & 11,16 & 7,07 & 5,01 & 10,98 & 12,43 \\
\hline & $83 / 84$ & 25,38 & 22,67 & 8,92 & 11,38 & 4,77 & 6,04 & 12,46 & 8,38 \\
\hline & $84 / 85$ & 19,64 & 23,26 & 9,16 & 5,62 & 15,83 & 6,29 & 10,63 & 9,57 \\
\hline & $85 / 86$ & 29,24 & 19,46 & 7,11 & 6,25 & 11,85 & 5,83 & 11,69 & 8,57 \\
\hline & $86 / 87$ & 28,22 & 23,55 & 6,54 & 6,53 & 10,94 & 4,15 & 13,46 & 8,12 \\
\hline \multirow{5}{*}{$\mathrm{RJ}$} & $82 / 83$ & 29,58 & 11,81 & 10,47 & 12,16 & 8,84 & 6,92 & 11,44 & 8,78 \\
\hline & $83 / 84$ & 24,26 & 10,22 & 9,97 & 12,33 & 11,67 & 10,15 & 12,61 & 8,79 \\
\hline & $84 / 85$ & 25,07 & 9,77 & 10,51 & 6,08 & 14,80 & 12,91 & 10,11 & 10,75 \\
\hline & $85 / 86$ & 26,44 & 14,10 & 7,92 & 7,51 & 13,18 & 10,08 & 11,40 & 9,37 \\
\hline & $86 / 87$ & 27,80 & 12,21 & 9,79 & 8,31 & 9,60 & 12,18 & 10,02 & 10,09 \\
\hline \multirow{5}{*}{$\mathrm{AL}$} & $82 / 83$ & 29,35 & 24,08 & 11,02 & 8,67 & 4,22 & 3,8 & 12,15 & 6,7 \\
\hline & $83 / 84$ & 33,67 & 24,20 & 8,54 & 7,06 & 4,80 & 3,42 & 11,08 & 7,23 \\
\hline & $84 / 85$ & 27,05 & 28,05 & 4,32 & 6,88 & 6,87 & 4,46 & 9,45 & 12,92 \\
\hline & $85 / 86$ & 35,50 & 22,97 & 4,32 & 7,40 & 5,67 & 4,44 & 9,09 & 10,61 \\
\hline & $86 / 87$ & 37,39 & 18,63 & 4,45 & 7,23 & 6,73 & 5,11 & 9,71 & 10,75 \\
\hline \multirow{5}{*}{$\mathrm{PE}$} & $82 / 83$ & 42,23 & 17,73 & 5,34 & 7,71 & 2,29 & 4,30 & 12,49 & 7,9 \\
\hline & $83 / 84$ & 42,01 & 20,28 & 4,84 & 8,20 & 2,78 & 4,02 & 10,85 & 7,02 \\
\hline & $84 / 85$ & 34,66 & 22,49 & 2,84 & 4,93 & 7,36 & 4,29 & 11,78 & 11,65 \\
\hline & $85 / 86$ & 43,98 & 16,95 & 2,82 & 7,83 & 3,90 & 4,37 & 7,84 & 12,31 \\
\hline & $86 / 87$ & 36,19 & 18,13 & 3,42 & 7,98 & 5,65 & 4,07 & 10,92 & 13,64 \\
\hline
\end{tabular}

Fonte: FGV/IAA $(1984,1985,1986,1987$ e 1988)

É interessante revelar que o plantio da cana-de-açúcar em São Paulo, apesar da heterogeneidade tecnológica existente dentro desse estado, está parcialmente mecanizado; enquanto a colheita - segmento carregamento e transporte - está totalmente mecanizado, e na colheita - segmento corte - o processo de utilização de máquinas avança persistentemente (Veiga Filho \& Santos, 1995). No caso específico do corte da cana mecanizado, Veiga Filho et al. (1994) estimam que a crescente substituição de mão- 
de-obra por máquinas poderá significar uma perda de 38.569 postos de trabalho em sete anos, para uma área passível de ser mecanizada correspondente a cerca de $46 \%$ da produção canavieira estadual.

As diferenças de custos entre os principais expoentes da agroindústria canavieira podem ser verificadas também em termos de custos industriais de produção do açúcar e álcool, que englobam o custo da matéria-prima no campo, o custo do transporte e o custo industrial propriamente dito (Lima, 1992). Tomando-se como referência a base de dados da DATAGRO para a safra 1984/85, citado por Eid (1996), o custo de produção do açúcar da macrorregião Centro-Sul é de US\$220 por tonelada de açúcar, enquanto o do Norte/Nordeste é de US\$ 300. Esse informativo ainda aponta os custos de produção do açúcar da África do Sul, Austrália, Tailândia, CEE, EUA e Japão (respectivamente, US\$ 230 , US\$ 270, US\$ 320, US\$ 470, US\$ 520, e US\$ 800 por tonelada). Logo, o Centro-Sul apresenta o menor custo de produção de açúcar do mundo. Em termos de álcool, Lima (1988a) ressalta que o custo de produção de álcool hidratado é $30 \%$ maior no Nordeste, comparativamente com São Paulo.

As diferenças nos custos de produção estão evidentemente ligadas às diferentes produtividades. A Comissão de Economia, Indústria e Comércio (1991), por exemplo, destacou a taxa de crescimento do rendimento agroindustrial do álcool (litros/ha) como sendo igual a 3,3\% a.a., isto em termos de Brasil e para o período de 1976/77 a 1989/90. Se se considerar as macrorregiões Centro-Sul e Norte/Nordeste em separado, verificarse-ão taxas de crescimento do rendimento agroindustrial do álcool equivalentes à $4,56 \%$ a.a. e 0,52\% a.a., respectivamente. Lima (1992) assinala a diferença entre os rendimentos agroindustriais do açúcar ( $\mathrm{kg}$ de açúcar/ha) para o Centro-Sul e Norte/Nordeste, no qual o primeiro é mais eficiente que o segundo em aproximadamente 30\% (safras 1978/79 a 1985/86).

Lima (1988a), ressalta que o diferencial de custos entre São Paulo e o Nordeste é significativo, bem como há também um relativo diferencial de custos em favor de Alagoas vis-à-vis a Pernambuco (exceto no caso do álcool anidro). Reforça-se aqui a idéia de que a sobrevivência de grupos pouco dinâmicos da agroindústria canavieira nordestina, responsáveis pelo atraso tecnológico e a conseqüente baixa produtividade do setor, devese sobremaneira à ação ambígua do Estado, que ao mesmo tempo em que criou 
condições para promover a expansão de grupos mais capitalizados, sustentou também grupos mais fracos (Lima, 1988a e 1988b).

Nesse panorama de disparidades existentes na agroindústria canavieira, cabe frisar o destaque ímpar de São Paulo em termos de melhores indicadores de produtividade do setor. De acordo com Balsadi et al. (1996), o rendimento agrícola da cana-de-açúcar (kg/ha) em São Paulo é cerca de $20 \%$ maior que o registrado em termos nacionais, pois são intensos os trabalhos de pesquisa e assistência técnica dedicados a essa cultura. Este destaque paulista pode ser estendido também à atividade industrial da produção de açúcar e álcool (COPERSUCAR, 1993; Eid, 1996; Fernandes \& Coelho, 1996).

Os ganhos de produtividade agrícola e agroindustrial no segmento canavieiro foram obtidos principalmente a partir do uso dos seguintes fatores: inovações biológicas, com novas variedades de cana oriundas de vários institutos de pesquisa; inovações físicoquímicas, como a utilização da fertirrigação com o vinhoto e as novas técnicas de fermentação alcoólica; inovações mecânicas, uso de tratores e implementos agrícolas mais desenvolvidos; e inovações associadas às formas de organização do trabalho e métodos de produção novas formas de gerenciamento global da produção agrícola e industrial, o reaproveitamento mais intensivo do bagaço da cana para a geração de energia, o corte da cana de sete ruas, dentre outros.

Como se concentram em São Paulo tanto as empresas produtoras de tecnologia como os mais importantes centros de pesquisa para o setor (COPERSUCAR, Dedini, IPT, ex-IAA e atual Centro de Ciências Agrárias da Universidade Federal de São Carlos, algumas unidades da Universidade de São Paulo - como a Escola Superior de Agricultura "Luiz de Queiroz" - etc), não só o padrão tecnológico da agroindústria canavieira passa a ser definido nesse estado (Ricci et al., 1994), como torna-se mais fácil essa difusão para regiões circunvizinhas, facilitando, assim, o desenvolvimento tecnológico de outros estados da macrorregião Centro-Sul.

É preciso salientar, todavia, que no levantamento de campo da safra 1995/96, a Fundação Getúlio Vargas (FGV) revelou alguns detalhes significativos sobre a recente evolução tecnológica da agroindústria canavieira. Para São Paulo, a pesquisa confirmou a elevada concentração de terras nas mãos das unidades industriais e/ou de grandes produtores, bem como o maior direcionamento para a colheita mecanizada e outras 
práticas visando a redução de custos, como a fertirrigação, aplicação de torta de filtro e racionalização gerencial e administrativa. Essa preocupação tecnológica também estendeu-se para os estados de Minas Gerais e Rio de Janeiro. Nos estados de Pernambuco e Alagoas, a transferência de parte da cultura da cana de áreas acidentadas para áreas mais planas e acessíveis às máquinas, e o uso intensivo de técnicas agrícolas, revelaram, assim como para seus congêneres do Centro-Sul, uma maior evolução tecnológica (Santos, 1996).

Essas colocações mostram o posicionamente recente de algumas usinas e destilarias, sendo sugestivas de uma maior assimilação do paradigma tecnológico como modelo de sobrevivência neste setor. Isto remete a presente análise ao outro aspecto mencionado no início desta seção, ou seja, a existência de produtores que adotaram um outro paradigma como modelo de sobrevivência.

O que tem ocorrido na agroindústria canavieira é o fato da maioria dos produtores, ao se inserir neste oligopólio, estar necessariamente sujeito a uma série de arranjos institucionais patrocinados pelo Estado, o que lhe garante um certo paradigma subvencionista como modelo de sobrevivência, onde o Estado interfere no padrão de busca das empresas da agroindústria canavieira. Com isso, muitos produtores habituaram-se a expedientes como a garantia de margens de lucro, reserva de mercado, concessão de subsídios, entre outros, mesmo diante do atual processo de desregulamentação gradativa do setor. Isto vem explicar a relativa falta de importância do progresso técnico na determinação das estruturas de mercado de grande parte da agroindústria canavieira.

Não obstante, a própria crise fiscal e financeira do Estado, concomitante com as variações dos mercados do açúcar e do álcool, revelaram uma outra posição emergente, qual seja: houveram, sim, produtores que, mesmo diante desse paradigma subvencionista, optaram pelo maior desenvolvimento tecnológico de suas estruturas produtivas, seja no âmbito agrícola, seja no âmbito industrial, demarcando desta forma uma outra dinâmica nesse processo de concorrência.

Neste contexto, percebe-se que algumas empresas ligadas à agroindústria canavieira assumiram um paradigma próprio - o paradigma tecnológico -, diferenciandose das demais empresas por meio de um maior progresso técnico. A redução nos custos 
de produção, através da adoção de inovações, apresentou-se como a trajetória tecnológica ideal para as empresas que se diferenciaram dentro da agroindústria canavieira. Para tanto, recorreu-se às atividades de pesquisa agronômica e industrial voltadas para o desenvolvimento setorial, enquanto as inovações tecnológicas criadas foram sendo implementadas mormente por um peculiar processo de learning-by-doing (LBD). Os resultados derivados da pesquisa e desse aprendizado através do processo produtivo foram revertidos em termos de maiores rendimentos na produção e/ou diminuição de custos, sendo os maiores usufrutuários dessas conquistas os empresários que implementaram essas inovações, situados em sua maioria nos estados mais tradicionais da agroindústria canavieira. É o caso de várias usinas da COPERSUCAR, consideradas, segundo Eid (1996), entre as mais modernas do País (como a São Martinho), e de outras usinas paulistas de grande porte e independentes (como a Usina da Barra e Usina Santa Elisa). Outros estados, sobretudo os do Norte/Nordeste, evidenciaram algumas unidades produtivas que progrediram na questão da tecnologia aplicada ao cultivo da cana-de-açúcar e na questão da racionalização gerencial/administrativa do parque industrial canavieiro (Santos, 1996).

Nesse posicionamento de fração da agroindústria canavieira, tem-se observado a introdução de novas tecnologias e inovações organizacionais para não só tornar mais competitivos seus dois principais produtos - o açúcar e o álcool - como também explorar as novas fronteiras que surgem a título de subprodutos. Para Stalder \& Burnquist (1996, p.104-5), "além de ganhos na eficiência produtiva, o desenvolvimento tecnológico tem permitido ampliar a série de subprodutos reaproveitáveis pela própria unidade de produção e vendidos a outras indústrias, aumentando a receita da atividade" agroindustrial canavieira.

A Tabela 13 retrata alguns aspectos do aproveitamento econômico dos subprodutos da agroindústria canavieira, os quais denotam: uma relativa diferenciação na rentabilidade (bruta) dos produtos enfocados; a opção economicamente mais vantajosa que a utilização do bagaço como fonte de energia proporciona - seja para usinas ou para destilarias - em comparação com o bagaço como componente para ração animal ou para venda; e a proposição de que há campo para uma maior exploração econômica de outros subprodutos da cana-de-açúcar como, por exemplo, da vinhaça e torta de filtro. 
Tabela 13 - Margem de comercialização do açúcar standard em usinas, incluindo o valor equivalente de subprodutos; do álcool em destilarias autônomas, considerando os subprodutos; e coeficientes de transformação, Brasil. Maio de 1994.

\begin{tabular}{c|lc}
\hline & \multicolumn{1}{|c}{ Produtos e subprodutos } & Margem de comercialização (\%) \\
\hline & Açúcar & 21,48 \\
& Álcool residual & 42,74 \\
& Bagaço (venda) & 43,27 \\
Açúcar standard & Bagaço (energia) & 57,53 \\
& Bagaço (ração) & 47,05 \\
& Torta de filtro & 44,94 \\
& Álcool, bagaço (energia)e torta & 102,23 \\
\hline & Alcool & 32,22 \\
& Bagaço & 51,20 \\
Álcool & Bagaço (energia) & 63,34 \\
& Bagaço (ração) & 54,29 \\
& Vinhaça & 34,05 \\
& Bagaço (energia), torta de filtro e & 85,41 \\
\hline \hline Coeficientes de transformação & vinhaça & \\
dos principais & Aḉcar & $100 \mathrm{~kg} /$ ton cana \\
produtos e subprodutos & Álcool residual (usina) & 13,3 litros/ton cana \\
da agroindústria & Álcool & 72,5 litros/ton cana \\
canavieira & Vinhaça & 13 litros/álcool \\
brasileira & Bagaço & $280 \mathrm{~kg} /$ ton cana \\
& Bagaço (energia) & $0,6 \mathrm{mwh} /$ ton bagaço \\
\hline
\end{tabular}

Fonte: Stalder \& Burnquist (1995, p.8-9).

Obs.: Nesse trabalho exploratório de Stalder \& Burnquist (1995, p.8), cuja contribuição foi no sentido de apresentar "uma forma simples de avaliar as vantagens econômicas de utilização de subprodutos, empregando o conceito de margem de comercialização da indústria", a margem empregada foi obtida através da diferença entre o valor de venda do produto e o preço pago à matériaprima utilizada na produção e venda desse produto.

\subsubsection{SITUAÇÃO FINANCEIRA ATUAL DAS EMPRESAS DA AGROINDÚSTRIA CANAVIEIRA}

Como a agroindústria canavieira vive um momento absolutamente crítico no que se refere à divida dos proprietários de usinas e destilarias, a situação financeira recente contribui para confirmar a existência de uma evolução diferenciada no setor e para demonstrar que de fato houve empresas que adotaram o paradigma tecnológico como padrão de concorrência, utilizando-se a maior produtividade (agrícola e industrial) como trunfo para se manterem financeiramente "saudáveis".

Um dos indicadores da situação financeira da agroindústria canavieira pode ser extraído a partir do índice de liquidez corrente (ILC) das empresas, apresentado pela Revista Visão através da edição especial denominada "Quem é Quem na economia 
brasileira". O ILC é o ativo circulante (ou disponivel mais realizável a curto-prazo) dividido pelo passivo circulante (ou exigivel a curto-prazo). Essa relação revela a capacidade da empresa de solver seus débitos a curto-prazo. Sendo assim, se o índice obtido for equivalente a 0,47 , por exemplo, significa dizer que, para cada unidade de valor monetário de compromisso, a empresa conta somente com a fração de $0,47 \mathrm{em}$ caixa ou a realizar a curto-prazo. A Tabela 14 destaca, para alguns anos, uma amostragem de empresas da agroindústria canavieira que apresentaram o ILC abaixo da unidade.

Tabela 14 - Proporção das empresas da agroindústria canavieira que apresentaram Índice de Liquidez Corrente (ILC) inferiores à unidade - para 1975, 1979, 1983, 1987 e 1991.

\begin{tabular}{|c|c|c|c|c|c|c|c|c|c|c|}
\hline \multirow[t]{2}{*}{ Estado } & \multicolumn{5}{|c|}{$\%$ sobre o total regional } & \multicolumn{5}{|c|}{$\%$ sobre o total nacional } \\
\hline & 1975 & 1979 & 1983 & 1987 & 1991 & 1975 & 1979 & 1983 & 1987 & 1991 \\
\hline Pará & - & . & - &. & - & - & - & - & - & - \\
\hline Pernambuco & 10,3 & 53,3 & 43,8 & 55,2 & 41,2 & 2,0 & 9,0 & 5,8 & 6,8 & 3,7 \\
\hline Alagoas & - & 61,9 & 53,8 & 28,6 & 21,4 & - & 7,3 & 5,8 & 1,7 & 1,6 \\
\hline Paraíba & - & 40,0 & 44,4 & 50,0 & 88,9 & - & 1,1 & 1,6 & 1,7 & 4,3 \\
\hline Rio Grande do Norte & - & 33,3 & 25,0 & 25,0 & 25,0 & $*$ & 0,6 & 0,4 & 0,4 & 0,5 \\
\hline Ceará & - & - & 33,3 & 100,0 & - & . & - & 0,4 & 1,3 & * \\
\hline Maranhão & - & . & - & - & - & . & . & - & - & . \\
\hline Sergipe & - & - & - & - & - & - & - & - & - & - \\
\hline Bahia & - & . & 75,0 & 50,0 & 66,7 & - & . & 1,2 & 0,8 & 1,1 \\
\hline Minas Gerais & - & 27,3 & 53,8 & 33,3 & 44,4 & - & 1,7 & 2,9 & 2,1 & 2,1 \\
\hline São Paulo & 13,9 & 40,5 & 44,8 & 42,6 & 34,8 & 6,8 & 18,1 & 19,4 & 19,4 & 16,6 \\
\hline Rio de Janeiro & 16,7 & 41,7 & 41,7 & 40,0 & 38,5 & 1,4 & 2,8 & 2,1 & 2,5 & 2,7 \\
\hline Espírito Santo & - & - & 40,0 & 57,1 & 60,0 & - & - & 0,8 & 1,7 & 1,6 \\
\hline Mato Grosso & - & - & 50,0 & 66,7 & 66,7 & - & - & 0,8 & 0,8 & 1,1 \\
\hline Mato Grosso do Sul & - & - & 100,0 & 25,0 & 33,3 & - & - & 0,4 & 0,4 & 0,5 \\
\hline Goiás & - & 100,0 & 37,5 & 50,0 & 50,0 & - & 0,6 & 1,2 & 2,1 & 1,6 \\
\hline Distrito Federal & - & - & 100,0 & - & - & . & . & 0,4 & - & - \\
\hline Santa Catarina & 33,3 & . & 50,0 & 25,0 & 66,7 & 0,7 & - & 0,8 & 0,4 & 1,1 \\
\hline Rio Grande do Sul & - & - & 50,0 & . & - & . & - & 0,4 & $=$ & - \\
\hline Paraná & - & 6,0 & 71,4 & 20,0 & 33,3 & & 1,7 & 2,1 & 0,4 & 1,1 \\
\hline Somatóriodo $\%$ & bre & $0 \mathrm{tot}$ & a $1 \mathrm{n}$ & $\operatorname{cion}$ & $1=$ & 10,9 & 42,5 & 46,7 & 42,5 & 39,6 \\
\hline
\end{tabular}

Os dados da Tabela 14 mostram o crescimento (até o ano de 1983) da proporção das empresas da agroindústria canavieira com o ILC menor do que 1 (vide somatório), sendo que nos anos de 1987 e 1991 ocorreu um decréscimo nesta proporção. Prima facie, poderia dizer que houve uma melhora financeira relativa no setor, posto que uma proporção menor de empresas estaria nessa situação incômoda. Entretanto, o que de fato ocorreu foi um processo de incorporação ou fusão de estabecimentos, quando não de 
encerramento de atividades, durante essa fase de crise do PROÁLCOOL, agravada pelo alto endividamento verificado nessa agroindústria.

Os estados que apresentaram, em 1991, mais da metade das empresas com o ILC menor do que 1 foram: Paraíba, Bahia, Espírito Santo, Mato Grosso e Santa Catarina. Vale citar que estes estados não são considerados tradicionais na agroindústria canavieira. Numa direção oposta, ou seja, para aqueles que apresentaram uma fração reduzida das empresas com o $\mathbb{I L C}$ menor do que 1, verificaram-se os seguinte estados: Alagoas, Rio Grande do Norte, São Paulo, Mato Grosso do Sul e Paraná. Destes, São Paulo e Alagoas são considerados estados tradicionais no setor, enquanto Mato Grosso do Sul e Paraná são consideradas novas fronteiras (na produção alcooleira). Numa posição intermediária figuram: Pernambuco, Minas Gerais, Rio de Janeiro e Goiás.

A análise do ILC, embora importante no contexto da situação financeira das empresas, pode revelar casos atípicos como o do estado de Alagoas. ${ }^{17}$ Por outro, e de modo geral, revelou que as empresas bem colocadas no levantamento da Revista Visão, sobretudo para aquelas situadas no Rio Grande do Norte, Mato Grosso do Sul, Paraná e São Paulo, apresentaram situações financeiras relativamente satisfatórias, corroborando a diferenciação existente na agroindústria canavieira.

Situando a dívida dos proprietários de usinas e destilarias junto ao Banco do Brasil, IAA, Receita Federal e Procuradoria da Fazenda Nacional, "isentas" de acordos que facilitem os balanços das empresas, verificou-se, para 1991, uma maior concentração dessa dívida em Pernambuco (com participação de 20,3\%), São Paulo (17,4\%), Rio de Janeiro (14,4\%), Alagoas (11,8\%) e Minas Gerais (9,3\%) (Tabela 15). Estados sem tradição neste setor, emergentes a partir da segunda fase do PROÁLCOOL, apresentaram um endividamento relativamente inferior aos demais. As participações percentuais no total da dívida de Mato Grosso, Goiás e Mato Grosso do Sul foram de, respectivamente, $3,2 \%, 2,7 \%$ e $0,8 \%$. Numa posição intermediária ficaram a Paraíba $(5,9 \%)$ e o Pará $(5,6 \%)$. Relativizando o total devido pelo setor sucroalcooleiro com o valor de produção da cana-de-açúcar, observaram-se três situações distintas: no Acre e Pará verificou-se uma dívida extremamente alta para um reduzido valor de produção da

\footnotetext{
${ }^{17}$ O artigo "CRISE em Alagoas arrasta o setor privado" (Folha de São Paulo, 1997) comenta que desde 1987 as usinas não pagam o Imposto de Circulação de Mercadorias e Serviços (ICMS), devido ao fato do então governador de Alagoas, Fernando Collor de Melo, ter assinado um acordo com os usineiros locais, transformando débitos do ICMS em créditos. Atualmente, isto já não acontece mais.
} 
cana-de-açúcar realizada; para Alagoas, Goiás, Mato Grosso do Sul, Paraná, Rio Grande do Norte e São Paulo verificou que o total devido pelo setor sucroalcooleiro não é superior ao valor de produção da cana-de-açúcar; e, numa situação intermediária entre estas duas situações, enquadraram-se os estados do Mato Grosso, Minas Gerais, Paraíba, Pernambuco e Rio de Janeiro. Assim como na análise do ILC, Alagoas, Rio Grande do Norte, Mato Grosso do Sul, Paraná e São Paulo apresentaram situações financeiras relativamente satisfatórias se se comparadas com o valor de produção da cana-de-açúcar.

Tabela 15 - Dívidas do setor sucroalcooleiro em 1991 (Cr\$ milhões de setembro de 1991), valor de produção da cana-de-açúcar (Cr\$ milhões de 1991) e relação total da dívida do setor sucroalcooleiro/valor de produção da cana (em \%).

\begin{tabular}{lrrrrrrr}
\hline $\begin{array}{c}\text { Esta- } \\
\text { do }\end{array}$ & $\begin{array}{r}\text { Banco do } \\
\text { Brasil }\end{array}$ & IAA & $\begin{array}{r}\text { Receita } \\
\text { Federal }\end{array}$ & $\begin{array}{r}\text { Procuradoria } \\
\text { da Fazenda } \\
\text { Nacional }\end{array}$ & $\begin{array}{r}\text { Total } \\
\text { da divida } \\
(\mathrm{A})\end{array}$ & $\begin{array}{r}\text { Valor de } \\
\text { produção } \\
\text { da cana (B) }\end{array}$ & $\begin{array}{r}\text { A/B } \\
(\%)\end{array}$ \\
\hline AC & $10.525,80$ & 0 & 0 & 0 & $10.525,80$ & 228,7 & 46,02 \\
AL & $61.985,90$ & $44.483,80$ & $8.523,20$ & $2.983,00$ & $117.975,90$ & $130.780,2$ & 0,90 \\
GO & $25.592,30$ & 7,20 & 932,30 & 695,60 & $27.227,40$ & $31.566,2$ & 0,86 \\
MT & $31.807,00$ & 0,50 & 0 & 0 & $31.807,50$ & $12.846,0$ & 2,48 \\
MS & $8.425,60$ & 0,20 & 0 & 0 & $8.425,80$ & $18.264,5$ & 0,46 \\
MG & $52.740,20$ & $25.268,10$ & $15.702,40$ & 0 & $93.710,70$ & $61.059,1$ & 1,53 \\
PA & $56.589,50$ & 2,60 & 0 & 0 & $56.592,10$ & $3.420,7$ & 16,54 \\
PB & $44.208,10$ & $2.582,20$ & $3.347,60$ & $8.730,50$ & $58.868,40$ & $48.314,4$ & 1,22 \\
PR & $18.119,10$ & 6,50 & $10.307,00$ & $5.659,80$ & $34.092,40$ & $63.740,3$ & 0,53 \\
PE & $127.656,20$ & $62.693,00$ & $10.118,60$ & $2.888,30$ & $203.356,10$ & $172.951,6$ & 1,18 \\
RJ & $38.754,20$ & $88.509,10$ & $14.919,30$ & $2.378,50$ & $144.561,10$ & $41.076,4$ & 3,52 \\
RN & $8.279,80$ & $1.830,60$ & 0 & $3.224,80$ & $13.335,20$ & $22.249,2$ & 0,60 \\
SP & $142.626,00$ & $27.643,10$ & $2.053,20$ & $2.425,70$ & $174.748,00$ & $722.235,0$ & 0,24 \\
Outros & $20.340,40$ & 699,00 & $2.900,60$ & $4.257,70$ & $28.197,70$ & $142.961,5$ & 0,20 \\
Total & $647.650,10$ & $253.725,90$ & $68.804,20$ & $33.243,90$ & $1.003 .424,10$ & $1.471 .693,8$ & 0,68 \\
\hline
\end{tabular}

Fonte: compilado do Relatório Comissão Interministerial, set. 1991, citado por Ricci et al. (1994, p.69); e Anuário Estatístico do Brasil (1993).

Segundo o artigo "GOVERNO estuda nova ajuda a usineiros" (Folha de São Paulo, 1995), a agroindústria deve a cifra estimada de $\mathrm{R} \$ 5$ bilhões ao Banco do Brasil incluindo multas, atualização monetária e encargos financeiros -, sendo que a falta de critério e o uso político na concessão de financiamentos aos usineiros contribuíram para esse elevado nível de inadimplência. Novamente aparece o Estado, através da figura do Banco do Brasil, como um sustentador dos riscos derivados de empreendimentos na agroindústria canavieira. Em tese, um risco sui generis, pois, segundo Ricci et al. (1994), os usineiros alegavam não pagar suas dívidas devido às políticas de preços da cana, açúcar e álcool praticadas pelo governo, ante ao agravamento dos custos de produção das usinas e destilarias. Assim, as cobranças judiciais encaminhadas pelo IAA, depois pela 
Receita Federal, não se mostraram eficazes. Como é sabido, a agroindústria canavieira sempre teve respaldo político no interior do aparelho do Estado, sendo um dos setores mais bem representados nessa esfera (Lima, 1988b; Ramos, 1991; Ricci et al., 1994).

Um documento do Tesouro Nacional, que chegou às mãos da imprensa revelava, por sua vez, a posição das dívidas externas dos usineiros pagas pelo Estado. Este anúncio foi feito pelo artigo "TESOURO paga Cr\$ 82,1 bilhões da dívida externa de 23 usinas" (Folha de São Paulo, 1991), em 28/02/91. Corrigindo esta monta para valores de junho de 1996 (IGP - base: junho/96), tem-se o equivalente a R\$ 739 milhões. Das 23 usinas e 4 cooperativas de produtores de açúcar e álcool citadas por este artigo, 9 pertencem ao Rio de Janeiro (correspondendo a 39,3\% do percentual total dessa dívida), 9 pertencem a Pernambuco (33,5\%), 4 pertencem a São Paulo (16,7\%), 4 pertencem a Minas Gerais $(6,7 \%)$ e 1 pertence a Alagoas (3,9\%) (Tabela 16).

Tabela 16 - Dívidas externas dos usineiros pagas pelo Governo (valores em 28/02/1991).

\begin{tabular}{llrc}
\hline \multicolumn{1}{c}{ Usina e cooperativa } & \multicolumn{1}{c}{ Estado } & Total em Cr\$ & Participação percentual (\%) \\
\hline Ariadnópolis & Minas Gerais & $545.586 .770,34$ & 0,7 \\
B. Lysandro & Rio de Janeiro & $89.336 .259,24$ & 0,1 \\
Baixa Grande & Rio de Janeiro & $39.906 .737,87$ & 0,05 \\
Bulhões & Pernambuco & $315.664 .890,02$ & 0,4 \\
Cambahyba & Rio de Janeiro & $69.158 .306,77$ & 0,08 \\
Central Barreiros & Pernambuco & $1.153 .549 .096,70$ & 1,4 \\
Central Paulista & São Paulo & $7.529 .330 .358,50$ & 9,2 \\
COPAL & Alagoas & $3.212 .603 .290,86$ & 3,9 \\
COPAMnAS & Minas Gerais & $1.684 .330 .995,72$ & 2,1 \\
COPER & Pernambuco & $22.461 .908 .075,00$ & 27,3 \\
COPERFLU & Rio de Janeiro & $31.915 .958 .213,77$ & 38,9 \\
Malvina & Minas Gerais & $1.476 .204 .889,48$ & 1,8 \\
Novo Horizonte & Rio de Janeiro & $13.751 .912,91$ & 0,02 \\
Outeiro & Rio de Janeiro & $32.934 .624,47$ & 0,04 \\
Paraíso & Rio de Janeiro & $46.873 .313,92$ & 0,06 \\
Rio Una & Pernambuco & $1.076 .665 .925,13$ & 1,3 \\
Riobranquense & Minas Gerais & $1.706 .309 .473,70$ & 2,1 \\
Serro Azul & Pernambuco & $97.344 .313,91$ & 0,1 \\
Santa Adelaide & São Paulo & $1.709 .443 .373,76$ & 2,1 \\
Santa Maria & Rio de Janeiro & $18.440 .108,91$ & 0,02 \\
Santa Rita & São Paulo & $1.895 .391 .961,30$ & 2,3 \\
Santa Therezinha & Pernambuco & $904.728 .950,75$ & 1,1 \\
Tamoio & São Paulo & $2.542 .455 .713,52$ & 3,1 \\
Tiriri & Pernambuco & $1.081 .297 .576,30$ & 1,3 \\
Treze de Maio & Pernambuco & $432.655 .021,59$ & 0,5 \\
União e Indústria & Pernambuco & $67.103 .906,25$ & 0,08 \\
Victor Sence & Rio de Janeiro & $17.674 .109,48$ & \\
\hline
\end{tabular}

Fonte: Folha de São Paulo (1991, p.1-9). 
De acordo com o artigo em ênfase (Folha de São Paulo, 1991), as dívidas foram avalizadas pelo extinto IAA, e pela listagem dos estabelecimentos evidencia-se que o Estado vai ter muita dificuldade para reaver o recurso gasto para honrar esses compromissos. A Cooperativa Fluminense dos Produtores de Açúcar e Álcool (COPERFLU), a maior devedora nessa lista, encerrou suas atividades em fins da década de 80. Assim como esta unidade, a Usina Tamoio, de São Paulo, Novo Horizonte e Santa Maria, ambas do Rio de Janeiro, também fecharam suas portas. A COPAMINAS, outra importante cooperativa do setor, encerrou recentemente suas atividades.

Neste aspecto abordado cabe frisar dois fatos: primeiro, dos cinco estados mais tradicionais da agroindústria canavieira, duas cooperativas já foram liquidadas, duas estão em delicada condição financeira, e apenas uma encontra-se em situação vantajosa neste setor produtivo. Trata-se, pois, da COPERSUCAR que, mesmo diante de um quadro de heterogeneidade tecnológica entre suas afiliadas, vem apresentando elevados ganhos de eficiência e produtividade, os quais são bastante influentes para sua "saúde" financeira. Novamente, evidencia-se o fato de alguns produtores adotarem o paradigma tecnológico como forma de definir o que é relevante para uma situação mais concorrencial. Segundo, o calote dado pelas empresas que encerraram suas atividades pertence, em grande parte, ao responsável pelo risco, ou seja, ao Estado. Numa alusão às idéias de Schumpeter, no caso do PROÁLCOOL a função de tomador de riscos coube sobremaneira ao Estado (vide Tabela 15), enquanto aos empresários coube a função de realizar novas combinações e introduzir as inovações.

Remontando a períodos mais recentes, em "LIBERAÇÃO de preços é uma opção estudada" (Folha de São Paulo, 1996) e "FAZENDA quer 'rolar' só créditos bons" (Folha de São Paulo, 1996), a Subcomissão de Financiamento do PROÁLCOOL, que está vinculada ao Ministério da Fazenda, constatou-se que do excessivo número de estabelecimentos produtores de álcool no Brasil (cerca de 346), apenas 57,8\% desses estabelecimentos foram considerados passíveis de salvação (quanto a sua situação financeira). Neste sentido, a estratégia do Estado é estimular fusões e trocas nos comandos acionários, além de propor o refinanciamento de suas dívidas. Em outro extremo, cerca de $11,0 \%$ das unidades avaliadas apresentaram diagnóstico de inviabilidade técnico-financeira e 12,1\% encerraram suas atividades. Outrossim, cerca de $19,1 \%$ dos estabelecimentos produtores de álcool estavam adimplentes com os seus financiamentos, apresentando todos os compromissos fiscais, previdenciários e 
trabalhistas em dia. Isto por terem basicamente diversificado suas produções e imposto uma administração mais eficiente, trabalhando em regime de alta produtividade (ou seja, adotando o paradigma tecnológico).

Segundo Olalde (1993), a partir de 1986 até a safra 1991/92, dos estabelecimentos produtores de açúcar e/ou álcool que deixaram de funcionar no Brasil, $71,6 \%$ estavam localizados na macrorregião Centro-Sul e $28,4 \%$ no Norte/Nordeste. A grande maioria das unidades desativadas $(82,1 \%)$ correspondiam a destilarias autônomas e apenas $17,9 \%$ correspondiam a usinas com destilaria anexa. No artigo "ALAGOAS pede mais subsídio" (Folha de São Paulo, 1995), constata-se que a crise na produção de cana, açúcar e álcool contribuiu para que fossem fechadas 5 usinas em Alagoas, 7 em Pernambuco, 6 na Paraíba, 1 no Rio Grande do Norte e 1 em Sergipe.

Adicionalmente, pela Tabela 17 pode-se observar como diminuiu o número de usinas de açúcar ao longo de três anos-safras, segundo escala de produção e macrorregião.

Tabela 17 - Distribuição das empresas de açúcar (unidades) segundo escala de produção safras de 1970/71, 1980/81 e 1991/92.

\begin{tabular}{ccccc}
\hline Producão $(\mathrm{t})$ & Macrorregião & $1970 / 71$ & $1980 / 81$ & $1991 / 92$ \\
\hline 1.000 a 26.000 & Centro-Sul & 116 & 37 & 41 \\
& Norte/Nordeste & 83 & 35 & 48 \\
\hline 26.001 a 51.000 & Centro-Sul & 36 & 48 & 40 \\
& Norte/Nordeste & 9 & 31 & 18 \\
\hline 51.001 a 76.000 & Centro-Sul & 8 & 19 & 5 \\
\hline & Norte/Nordeste & 4 & 19 & 5 \\
\hline 76.001 a 101.000 & Centro-Sul & 2 & 3 & 0 \\
\hline & Norte/Nordeste & 2 & 1 & 1 \\
\hline 101.001 a 126.000 & Centro-Sul & 0 & 3 & 1 \\
& Norte/Nordeste & 0 & 0 & 0 \\
\hline 126.001 a 151.000 & Centro-Sul & 1 & 3 & 1 \\
& Norte/Nordeste & 0 & 0 & 0 \\
\hline 151.001 a 176.000 & Centro-Sul & 0 & 1 & 1 \\
& Norte/Nordeste & 0 & 0 & 0 \\
\hline 176.001 a 201.000 & Centro-Sul & 0 & 0 & 1 \\
& Norte/Nordeste & 0 & 0 & 0 \\
\hline mais de 201.000 & Centro-Sul & 0 & 2 & 82 \\
\hline total & Norte/Nordeste & 0 & 0 & \\
& Centro-Sul & 163 & 116 & 86 \\
\hline
\end{tabular}

Fonte: IAA e SDR, dados baseados nos planos de safra, citado por Lima (1992). 
Segundo dados da Tabela 17, de um total de 261 usinas existentes em 1970/71, passou-se para 202 unidades em 1980/81 e 196 unidades em 1991/92. Para o Centro-Sul pode-se destacar tanto a relativa redução no número de usinas com menor escala de produção, apesar da oscilação verificada, como o gradual aumento de usinas cujo porte varia entre 76.001 a 101.000 toneladas e 126.001 a 151.000 toneladas. Especificamente para o Norte/Nordeste, a redução ocorreu para as usinas situadas até 26.000 toneladas, apesar da oscilação verificada, e de usinas situadas entre 76.001 a 101.000 toneladas. Por outro lado, as usinas situadas entre 26.001 a 51.000 toneladas passaram a contar com 28 unidades em 1991/92, depois de atingirem o número de 31 e 9 unidades, respectivamente, em 1980/81 e 1970/71.

Para Lima (1992), como observação importante extraída a partir dos dados da Tabela 17 pode-se dizer, de modo geral, que no Centro-Sul as pequenas usinas cederam espaço às grandes usinas. No Norte/Nordeste tal fato não ocorreu, havendo apenas diminuição do número das pequenas usinas. Vale anotar, segundo Ramos \& Belik (1989), que na agroindústria canavieira as concentrações industrial e fundiária caminham juntas. De acordo com Cochrane, os mais eficientes produtores irão expandir suas operações através da compra de ativos produtivos de produtores menores e menos eficientes. Neste contexto, a tendência visualizada é de um virtual processo de concentração da posse de terras e de outros ativos. E, para" Nelson \& Winter (1982), a concorrência schumpeteriana tende a produzir vencedores e perdedores, onde algumas firmas certamente tirarão maior proveito das oportunidades técnicas do que outras.

Essas considerações vão de encontro com a perspectiva de reconcentração do oligopólio na agroindústria canavieira, como observou Eid (1996). O interessante neste processo de reconcentração, segundo Olalde (1993), é que boa parte das empresas da agroindústria canavieira paulista que encerraram suas atividades ostentavam baixos índices de produtividade, não tinham experiência relevante na atividade e nem decisão de investir em capacitação tecnológica, estando localizadas, em certos casos, em solos marginais para a lavoura canavieira. Ademais, para a referida autora, essas empresas teriam sido fruto da "corrida do álcool" empreendida por muitos empresários oportunistas, verificada a partir da segunda fase do PNA, e que sem as benesses do Estado não teriam como sustentar sua atividade produtiva. 
Diante da exposição feita, há que destacar três pontos: primeiro, o uso político na concessão de financiamentos aos usineiros e a falta de critérios contribuíram para o elevado nível de inadimplência na agroindústria canavieira; segundo, o Estado aparece como o sustentador dos riscos derivados de empreendimentos na agroindústria canavieira; e terceiro, as empresas que adotaram o paradigma tecnológico como padrão de concorrência, utilizando-se a maior produtividade (agrícola e industrial) como trunfo para se manterem financeiramente "saudáveis", estão sem dívidas ou adimplentes com os seus compromissos.

\subsubsection{PERSPECTIVAS PARA A AGROINDÚSTRIA CANAVIEIRA}

Sobre as perspectivas para o setor, os mercados atuais dos dois principais produtos da agroindústria canavieira - o açúcar e o álcool - atravessam uma fase de alta concorrência. O álcool, por exemplo, se defronta atualmente com várias alternativas concorrentes, dentre essas cabe citar: a gasolina de alta octanagem sem carência de chumbo ou de outros aditivos, alguns sucedâneos químicos como o metanol, o etanol sintético, o MTBE (eter-methil-butil terciário) e o TBA (álcool tércio-butílico), além do etanol ou álcool etílico de origem vegetal extraído a partir de matérias-primas alternativas à cana-de-açúcar (Szmrecsányi, 1989). No caso do açúcar, segundo Jank (1989), além da tendência secular de aumento do grau de auto-suficiência em açúcar - facilitada pela possibilidade de obter açúcar a partir de fontes de diferentes condições edafo-climáticas -, a demanda de sacarose nos países desenvolvidos tem diminuído, sobretudo no Japão, Canadá e Estados Unidos. Uma das razões para isto está no fenômeno da concorrência e substitutibilidade que atingem o mercado de açúcar desde a década dos 70 . Dentre os principais produtos que passaram a competir com a sacarose estão os adoçantes à base de amido de cereais (HFCS: High Fructose Corn Syrup), os novos produtos de origem química (Aspartame), entre outros produtos calóricos e não calóricos (veja o apêndice B para os comentários sobre esses produtos).

Dados de Carvalho et al. (1988, p.846), para os Estados Unidos, apontam que "no periodo de 12 anos, compreendido entre 1975 e 1987, o consumo anual de açúcar decresceu cerca de 1,7 milhões de toneladas, enquanto a utilização de adoçantes, incluindo os derivados do milho, aumentou em 3,4 milhões de toneladas." 
Para Szmrecsányi (1989), no caso específico do açúcar, pelo fato deste produto ter se transformado de um gênero alimentício de consumo direto em matéria-prima industrial, ele se tornou substituível por outras matérias-primas. Cabe acrescentar que uma das tendências responsáveis pela queda do consumo de açúcar e crescimento do consumo de adoçantes substitutos e concorrentes do açúcar está no fato de que "o estilo light ou diet deixa de ser uma obrigação de pessoas diabéticas ou com problemas de obesidade, para tornar-se uma opção de adeptos de dietas menos calóricas" (TECNOLOGIA amplia uso de adoçantes, 1993, p.05).

Neste ínterim, a resposta da agroindústria canavieira ao fenômeno da concorrência e substitutibilidade, que atingem o mercado açucareiro desde a década de 70, parece estar vindo em forma de um novo tipo de açúcar. Este produto, originário da própria cana-de-açúcar, permanece com a capacidade de adoçar comidas e bebidas sem, contudo, gerar os efeitos iníquos que o açúcar comum (sacarose) pode provocar, ou seja, engordar indesejavelmente as pessoas, causar cáries e prejudicar pacientes de diabetes (AÇÚCAR ideal, 1991).

Essa nova tecnologia de produção de açúcar - criada por dois pesquisadores do Departamento de Ciências dos Alimentos da Universidade Estadual de Campinas (UNICAMP), e que tem usado como fase de produção piloto a Usina da Barra (SP) baseia-se na produção da enzima frutosiltransferase, a partir de um fungo denominado Aspergillus niger, encontrado no próprio solo dos canaviais. Essa enzima, misturada ao açúcar, consegue romper a ligação glicose-frutose na molécula de sacarose. O corolário disso é um conjunto de moléculas, os frutooligossacarídeos, que, após ser purificado para a retirada de resíduos de glicose e sacarose, conserva a propriedade natural de adoçar alimentos com sabor semelhante ao açúcar tradicional, mas perde a maior parte do potencial que tem de elevar o peso corporal e de ser cariogênico (NOVO açúcar beneficia diabéticos e obesos, 1997).

Essa novidade para a agroindústria canavieira, a ser testada no mercado provavelmente a partir de 1998, desponta-se como uma forma encontrada por este setor produtivo para não se tornar vítima do processo inovativo que lançou no mercado os vários adoçantes substitutos e concorrentes do açúcar. Conforme Schumpeter ressaltou, o processo de mudanças tecnológicas possibilita revolucionar a estrutura econômica a partir de dentro, criando elementos novos (neste caso, o açúcar que não é metabolizado 
e, portanto, não produz calorias) e procurando destruir o antigo (basicamente os adoçantes), como num processo de "destruição criadora". Convém ressaltar que o açúcar calórico continua tendo a sua importância no contexto alimentar, sobretudo para as camadas de baixa renda. Outrossim, mais uma vez verifica-se o estado de São Paulo, através da Usina da Barra, como o pioneiro neste tipo de pesquisa.

Ainda sobre as perspectivas para o setor, especificamente para o mercado nacional do açúcar (cuja a monta é de 7,5 milhões de toneladas métricas, 6 milhões consumidos na macrorregião Centro-Sul e 1,5 milhão no Norte-Nordeste), pode-se constatar, segundo Sotero (1996, p.22), um enorme potencial para o desenvolvimento de negociações feitas através das bolsas de mercadorias, futuros e opções.

"A prática da gestão de preços do açúcar através das bolsas (...) ainda é pouco difundido no setor sucroalcooleiro nacional, que dispõe atualmente de um novo mecanismo para reduzir os riscos de preços da atividade: os contratos futuros de açúcar cristal especial, lançados de forma inovadora e pioneira pela Bolsa de Mercadorias e Futuros de São Paulo $B M \& F . "$ - grifo nosso.

Em termos do álcool combustivel, a reação contra a crise do PROÁLCOOL parece estar vindo em forma de uma renovada "orquestração" de interesses em torno desse Programa, assentada maiormente na proposta de criação do "imposto verde". Em "GOVERNO apressa criação do imposto verde" (Folha de São Paulo, 1997), o chamado "imposto verde" - tributo sobre o consumo de combustíveis - deverá conter medidas como: aumento na proporção do álcool anidro misturado à gasolina (de $22 \%$ para $29 \%$ ); adição de álcool anidro ao diesel numa proporção de $10 \%$ a $15 \%$; manter a isenção do Imposto sobre Produtos Industrializados (IPI) para taxistas que optarem pelos modelos a álcool; obrigar a troca de veículos oficiais a gasolina pelos movidos a álcool. Para o Estado, o estímulo ao PROÁLCOOL não se deve somente ao fato do álcool ser menos poluente vis-à-vis a gasolina e o diesel, a estabilidade da produção sucroalcooleira também é uma preocupação do governo federal. Novamente, tanto para o setor de máquinas e equipamentos como para a indústria automobilística, os interesses no revigoramento do PROÁLCOOL devem-se às perspectivas de relativo crescimento das vendas. Já para a agroindústria canavieira, a volta do apoio ao PROÁLCOOL significa dar, no curto-prazo, vazão para o excedente estimado de 2,3 milhões de litros de álcool 
que será fabricado na safra 1997/98 e, no médio e longo-prazos, diminuir a volatibilidade na renda do produtor de cana, açúcar e álcool.

O capítulo seguinte procura, por meio da utilização da técnica de análise fatorial, obter algumas medidas do grau de modernização da agroindústria canavieira e da desigualdade existente entre os estados brasileiros, de modo a obter maiores informações sobre a hipótese realçada pelo presente trabalho. 


\section{MEDIDAS DO GRAU DE MODERNIZAÇÃO DA AGROINDÚSTRIA CANAVIEIRA NO BRASIL UTILIZANDO A ANÁLISE FATORIAL}

Neste capitulo procura-se, através do procedimento da análise fatorial pelo método dos componentes principais, obter algumas medidas do grau de modernização da agroindústria canavieira do Brasil, de modo a captar a evolução dessa agroindústria em três anos característicos - 1975 (ano início da $1^{\stackrel{a}{ }}$ fase do PROÁLCOOL), 1980 ( $1^{\circ}$ ano da $2^{\underline{a}}$ fase do PROÁlCOOL) e 1985 (ano final da $2^{\underline{a}}$ fase do PROÁlCOOL) - e para os mais representativos estados produtores do País. Procura-se evidenciar a importância do PROÁLCOOL no processo de modernização do parque agroindustrial da cana-deaçúcar. Também observa-se até onde o PROÁLCOOL contribuiu para consolidar a hegemonia de São Paulo neste panorama. Não obstante, verifica-se como outros estados tradicionais neste setor (Alagoas, Pernambuco, Rio de Janeiro e Minas Gerais) se comportaram durante os períodos enfocados pela análise fatorial; observando-se também o comportamento dos estados emergentes (Paraná e Mato Grosso do Sul). Desta forma, na seção 6.1 faz-se um breve comentário sobre a análise fatorial proposta. Em seguida, são realçados o tratamento dos dados (seção 6.2) e os resultados obtidos (seção 6.3), sendo expostas nesta última parte as principais implicações a que este capítulo chegou.

\subsection{NOTAS SOBRE A ANÁLISE FATORIAL}

A análise fatorial é um dos métodos de análise multivariada que reduz um conjunto relativamente grande de variáveis a um número menor de fatores, permitindo, assim, um exame sintético das variáveis observadas. Neste caso, os fatores obtidos possibilitam identificar um padrão de relações entre as variáveis de modo a reproduzir o que elas partilham em comum. Existem vários métodos para realizar uma análise fatorial, dentre os quais: o método de máxima verossimilhança, dos fatores principais e dos componentes principais. 
Não é intento deste trabalho detalhar o conjunto de métodos matemáticosestatísticos que caracterizam a análise fatorial e o método dos componentes principais. Sobre a descrição desses métodos ver, por exemplo: Harman (1976), Johnson \& Wichern (1982), Llanillo (1984) e Hoffmann (1994). Sobre aplicações desse método ver, por exemplo: Hoffinann (1992) e Figueiredo (1996).

Neste trabalho pretende-se obter, de maneira simples, um número pequeno de fatores indicadores do grau de modernização da agroindústria canavieira do Brasil, o que direciona esta análise, ainda que não exclusivamente, para o método dos componentes principais.

Destarte, analisando-se 14 estados brasileiros, a partir de um conjunto de 13 indicadores de modernização e caracterização da agroindústria canavieira para cada ano enfocado (1975, 1980 e 1985), definem-se:

$$
\begin{aligned}
& X_{1} \text { a matriz } 14 \times 13 \text { para } 1975 ; \\
& X_{2} \text { a matriz } 14 \times 13 \text { para } 1980 \text {; e, } \\
& X_{3} \text { a matriz } 14 \times 13 \text { para } 1985
\end{aligned}
$$

Agregando-se as observações referentes aos três anos (visando-se obter a dinâmica do processo de modernização), define-se a matriz 42 x 13:

$$
X=\left[\begin{array}{l}
X_{1} \\
X_{2} \\
X_{3}
\end{array}\right]
$$

Se fosse feita uma análise fatorial para cada ano não haveria a possibilidade de comparações intertemporais, visto que os fatores não seriam exatamente os mesmos. Com o procedimento de agrupar os três anos (1975, 1980 e 1985), pode-se obter uma medida da velocidade do processo de modernização para cada estado. "A velocidade da modernização em um determinado periodo é dada pela diferença entre os valores do fator nos dois cortes temporais extremos (...), um para o periodo 1975/1980 e outro para 1980/1985" (Figueiredo, 1996, p.41). 


\subsection{TRATAMENTO DOS DADOS}

Procurando captar alguns aspectos da modernização da agroindústria canavieira para os anos de 1975, 1980 e 1985, foram destacadas 13 variáveis ou indicadores de modernização e caracterização dessa agroindústria, a partir de dados coletados junto às instituições como o IAA (antes de sua extinção) e a CENAL, além dos dados publicados pelos Censos Agropecuários dos estados em questão e Anuários Estatísticos do Brasil. A seleção dessas variáveis baseou-se na literatura brasileira sobre a análise fatorial - por exemplo, Hoffmann (1992) e Figueiredo (1996) -, bem como na disponibilidade de dados sobre a agroindústria canavieira.

Em decorrência das dificuldades inerentes à coleta de dados sobre a agroindústria canavieira, especialmente após a extinção do IAA, uma breve exposição dos ajustes realizados faz-se necessária. Em primeiro lugar, foram selecionados neste trabalho apenas os estados mais representativos desse setor produtivo e outros de importância secundária, posto que em alguns Censos Agropecuários não foram destacadas algumas variáveis fundamentais para a presente análise, impedindo, assim, a inclusão de estados como Goiás e Maranhão. Outra dificuldade diz respeito ao tratamento dos dados dos estados de Mato Grosso e Mato Grosso do Sul. Como a separação desses estados ocorreu em 1977, os dados anteriores a este ano (que medem os usos de insumos modernos), referentes a Mato Grosso, serão considerados, a fortiori, também para o Mato Grosso do Sul. Esta alternativa se fundamenta na semelhança desses dados entre os dois estados. Outrossim, em outros casos utiliza-se da aptidão alcooleira do Mato Grosso do Sul como elemento norteador para a partilha dos dados. Ocorrendo o inverso, isto é, na falta de dados para Mato Grosso, utilizar-se-á a base de dados de Mato Grosso do Sul como referência. A última dificuldade diz respeito à falta de dados para algumas variáveis que deveriam retratar os anos considerados neste trabalho (1975, 1980 e 1985), o que implicou na utilização de dados de anos ou anos-safras próximos ao considerado.

Dentre as informações básicas obtidas junto à FIBGE (Censos Agropecuários), constatou-se que o total de área plantada com cana-de-açúcar em Alagoas em 1975 foi maior que o total de área plantada com lavouras temporárias e permanentes nesse mesmo ano. Neste caso, decidiu-se considerar, a fortiori, a informação de que em 1975 a relação área plantada com cana-de-açúcar sobre o total de área com lavouras temporárias e permanentes em Alagoas foi igual à verificada em 1980. 
A seguir, qualificam-se as 13 variáveis usadas no presente estudo (dispostas sinteticamente na Tabela 18), escolhidas de modo a identificar fatores relacionados à questão da modernização e caracterização da agroindústria canavieira. As variáveis 1 a 3 são variáveis referentes ao uso de insumos e técnicas modernas no segmento agrícola; as variáveis 4 e 5 medem a escala industrial; as variáveis 6 a 8 medem os rendimentos agrícola e industrial; a variável 9 refere-se ao investimento; a variável 10 representa uma forma específica de comercialização (a proporção de cana-de-açúcar que é entregue à indústria); e, as variáveis 11 a 13 retratam o grau de especialização do estado na cultura canavieira (em termos estaduais e nacional). Cabe frisar que não foi possível a obtenção de dados que pudessem medir a mecanização agrícola na agroindústria canavieira.

\section{Uso de insumos e técnicas modernas no segmento agrícola: ${ }^{18}$}

Variável 1 - \% da área de colheita da cana-de-açúcar que usou defensivos;

Variável 2 - \% da área de colheita da cana-de-açúcar que usou adubação;

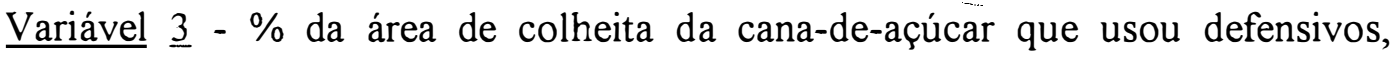
adubação, sementes selecionadas (1975 e 1980) e compradas (1985), irrigação;

\section{Escala industrial:}

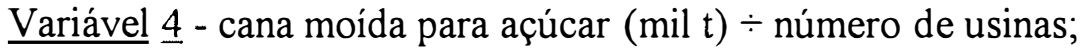

(obs.: para o ano de 1975 utilizou-se a cana moída da safra 1975/76 pelo número de usinas de 1975, para o ano de 1980 utilizou-se a cana moída da safra 1979/80 $\div$ pelo número de usinas de 1979 , para o ano de 1985 utilizou-se a cana moída da safra 1985/86 - pelo número de usinas de 1985)

Variável 5 - cana moída para álcool $($ mil t $) \div$ número de destilarias;

(obs.: para o ano de 1975 utilizou-se a cana moída da safra 1978/79 pelo número de destilarias de 1978, para o ano de 1980 utilizou-se a cana moída do ano de $1981 \div-$ pelo número de destilarias de 1981, para o ano de 1985 utilizou-se a cana moída da safra 1985/86 $\div$ pelo número de destilarias de 1985)

\footnotetext{
${ }^{18}$ Torna-se necessário enfatizar que os Censos Agropecuários do Brasil denominam o uso de irrigação, defensivos, adubação e/ou sementes selecionadas (compradas), como tecnologia aplicada. Todavia, o item irrigação - com água - é uma técnica que, dependendo do estado considerado, por exemplo o Paraná, não assume a mesma importância que nos estados nordestinos, isto devido às condições edafo-climáticas.
} 


\section{Rendimentos agrícola e industrial:}

$\underline{\text { Variável } 6}$ - rendimento agrícola da cana-de-açúcar $(\mathrm{kg} / \mathrm{ha})$;

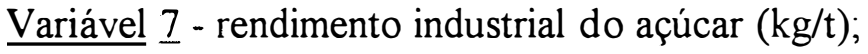

(obs.: para o ano de 1975 utilizou-se dados da safra 1975/76, para o ano de 1980 utilizou-se dados da safra 1980/81, para o ano de 1985 utilizou-se dados da safra 1985/86)

Variável 8 - rendimento industrial do álcool (litros/t);

(obs.: para o ano de 1975 utilizou-se dados da safra 1978/79, para o ano de 1980 utilizou-se dados da safra 1980/81, para o ano de 1985 utilizou-se dados da safra 1985/86)

\section{Indicador de investimento:}

$\underline{\text { Variável }} \underline{9}-\%$ dos investimentos (correspondentes à amostragem das maiores usinas e destilarias do setor) em termos de patrimônio líquido;

(obs.: para o ano de 1975 utilizou-se dados do ano de 1979)

\section{Indicador de forma de comercialização:}

Variável 10 - \% da produção de cana-de-açúcar que é entregue à indústria sobre o total da produção de cana-de-açúcar que é comercializada.

\section{Grau de especialização na cultura canavieira:}

$\underline{\text { Variável }} \underline{11}$ - total da área plantada com cana-de-açúcar no estado $\div$ total da área plantada com lavouras temporárias e permanentes no estado.

$\underline{\text { Variável }} \underline{12}$ - total da área plantada com cana-de-açúcar no estado $\div$ total da área explorada no estado.

(obs.: considerou-se a área explorada como sendo a soma das áreas com lavouras permanentes e temporárias, pastagens plantadas e naturais, e matas plantadas e naturais)

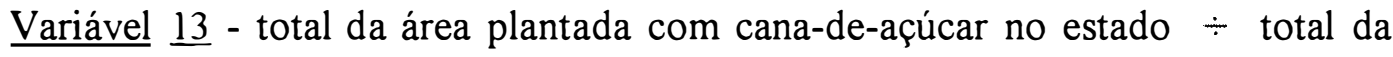
área plantada com cana-de-açúcar no Brasil.

Ao final da Tabela 18 estão as fontes dos dados utilizados. 
Tabela 18 - Matriz de dados para a Análise Fatorial.

\begin{tabular}{|c|c|c|c|c|c|c|c|c|c|c|c|c|c|c|c|}
\hline \multirow{2}{*}{$\begin{array}{l}\text { Varià } \\
\text { veis }\end{array}$} & \multirow[t]{2}{*}{ Ano } & \multicolumn{14}{|c|}{ Estado } \\
\hline & & SP & $\mathrm{MG}$ & ES & $\mathrm{RJ}$ & PR & MS & $\mathrm{MT}$ & $\mathrm{AL}$ & $\mathrm{PE}$ & $\mathrm{SE}$ & $\mathrm{PB}$ & $\mathrm{BA}$ & $\mathrm{RN}$ & $\mathrm{CE}$ \\
\hline 1 & 85 & 88,6 & 66,1 & 43,7 & 29,9 & 67,6 & 84,1 & 73,7 & 58,8 & 59,2 & 95,0 & 66,8 & 56,7 & 89,1 & 20,4 \\
\hline 1 & 80 & 90,3 & 67,9 & 42,8 & 37,8 & 83,0 & 90,0 & 90,0 & 54,4 & 60,7 & 81,1 & 67,5 & 41,6 & 86,9 & 22,4 \\
\hline 1 & 75 & 78,9 & 49,9 & 27,8 & 44,0 & 62,3 & 43,2 & 43,2 & 39,0 & 46,3 & 83,0 & 35,7 & 21,0 & 59,2 & 10,7 \\
\hline 2 & 85 & 98,0 & 76,3 & 75,8 & 75,1 & 88,9 & 93,9 & 87,2 & 93,7 & 94,1 & 96,3 & 82,0 & 59,0 & 97,0 & 62,2 \\
\hline 2 & 80 & 98,6 & 76,5 & 71,7 & 75,5 & 90,3 & 91,7 & 91,7 & 95,8 & 95,2 & 97,2 & 84,4 & 48,0 & 96,8 & 58,5 \\
\hline 2 & 75 & 98,0 & 59,6 & 41,4 & 70,0 & 89,9 & 41,0 & 41,0 & 94,0 & 94,4 & 86,2 & 73,3 & 39,5 & 84,1 & 40,7 \\
\hline 3 & 85 & 1,02 & 0,87 & 0,94 & 0,84 & 1,02 & 0,85 & 0,63 & 0,97 & 1,13 & 1,01 & 0,68 & 0,59 & 0,96 & 0,87 \\
\hline 3 & 80 & 1,06 & 0,90 & 0,74 & 1,01 & 1,07 & 0,82 & 0,82 & 1,09 & 1,10 & 0,96 & 0,80 & 0,35 & 1,01 & 0,57 \\
\hline 3 & 75 & 1,11 & 0,48 & 0,62 & 1,03 & 0,71 & 0,36 & 0,36 & 1,20 & 1,25 & 1,05 & 0,86 & 0,44 & 0,81 & 0,52 \\
\hline 4 & 85 & 510,0 & 363,3 & 338,1 & 308,0 & 501,7 & 0,0 & 406,4 & 463,5 & 417,4 & 406,8 & 257,9 & 226,7 & 643,7 & 132,2 \\
\hline 4 & 80 & 498,0 & 374,9 & 319,5 & 364,1 & 658,3 & 0,0 & 195,0 & 453,1 & 392,9 & 241,2 & 220,7 & 100,2 & 446,2 & 155,8 \\
\hline 4 & 75 & 395,0 & 203,4 & 227.9 & 375,5 & 476,4 & 0,0 & 65,9 & 360,7 & 344,6 & 159,6 & 161,4 & 125,9 & 246,5 & 104,9 \\
\hline 5 & 85 & 601,7 & 170,4 & 290,6 & 210,6 & 339,7 & 354,5 & 146,5 & 362,3 & 196,1 & 148,4 & 316.3 & 103,7 & 332,6 & 76,0 \\
\hline 5 & 80 & 286,1 & 99,4 & 0 & 77,4 & 135,2 & 148,2 & 107,7 & 237,4 & 94,3 & 0 & 159,3 & 20,9 & 211,3 & 0 \\
\hline 5 & 75 & 183,3 & 35,1 & 0 & 47,1 & 32,1 & 0 & 0 & 211,3 & 20,9 & 0 & 125,8 & 0 & 0 & 0 \\
\hline 6 & 85 & 75,5 & 57,8 & 60,2 & 50,4 & 74,0 & 62,6 & 58,0 & 50,3 & 50,4 & 60,6 & 60,4 & 40,6 & 49,1 & 42,1 \\
\hline 6 & 80 & 72,4 & 43,6 & 31,0 & 48,2 & 76,8 & 52,0 & 49,1 & 49,0 & 48,1 & 57,3 & 48,5 & 42,0 & 49,4 & 25,0 \\
\hline 6 & 75 & 57,3 & 32,6 & 31,0 & 45,0 & 50,1 & 37,9 & 37,9 & 46,1 & 48,0 & 53,0 & 40,9 & 42,0 & 57,7 & 35,0 \\
\hline 7 & 85 & 107,1 & 101,1 & 93,0 & 88,4 & 100,8 & 0,0 & 92,0 & 93,8 & 98,1 & 89,0 & 88,8 & 74,6 & 104,2 & 87,9 \\
\hline 7 & 80 & 97,0 & 101,1 & 90,1 & 79,8 & 90,3 & 0,0 & 102,2 & 80,8 & 88,8 & 90,9 & 83,5 & 79,3 & 96,2 & 84,3 \\
\hline 7 & 75 & 94,3 & 90,4 & 89,0 & 83,4 & 73,2 & 0,0 & 74,6 & 72,8 & 78,8 & 94,3 & 83,4 & 84,2 & 92,2 & 69,9 \\
\hline 8 & 85 & 73,6 & 72,5 & 65,3 & 53,1 & 72,3 & 70,7 & 54,5 & 69,6 & 68,0 & 73,0 & 65,8 & 54,2 & 72,8 & 71,4 \\
\hline 8 & 80 & 64,0 & 64,5 & 0,0 & 60,0 & 59,9 & 62,2 & 0,0 & 59,8 & 65,5 & 0,0 & 62,4 & 0,0 & 68,3 & 0,0 \\
\hline 8 & 75 & 58,9 & 0,0 & 0,0 & 0,0 & 42,3 & 0,0 & 0,0 & 59,7 & 0,0 & 0,0 & 57,6 & 0,0 & 55,5 & 0,0 \\
\hline 9 & 85 & 50,2 & 6,2 & 0,006 & 2,3 & 0,05 & 0,46 & 0,0 & 12,7 & 15,2 & 1,8 & 0,54 & 0,61 & 0,78 & 0,26 \\
\hline 9 & 80 & 75,4 & 5,1 & 0,04 & 4,4 & 0,12 & 0,0 & 0,0 & 4,6 & 9,2 & 0,3 & 0,06 & 0,09 & 0,06 & 0,32 \\
\hline 9 & 75 & 82,5 & 0,9 & 0,13 & 5,0 & 0,44 & 0,0 & 0,0 & 4,6 & 5.8 & 0,2 & 0,01 & 0,19 & 0,05 & 0,01 \\
\hline 10 & 85 & 98,7 & 89,0 & 95,2 & 94,7 & 75,8 & 88,8 & 91,0 & 97,2 & 97,0 & 90,6 & 83,9 & 82,9 & 95,4 & 70,7 \\
\hline 10 & 80 & 97,2 & 82,4 & 87,1 & 91,8 & 82,5 & 91,5 & 91,5 & 95,8 & 95,9 & 95,7 & 89,5 & 72,5 & 97,5 & 62,0 \\
\hline 10 & 75 & 94,0 & 74,0 & 72,8 & 94,4 & 76,3 & 83,7 & 83,7 & 96,9 & 94,2 & 96,5 & 82,0 & 66,4 & 86,7 & 38,6 \\
\hline 11 & 85 & 39,8 & 13,0 & 11,2 & 57,1 & 4,3 & 6,4 & 4,5 & 86,0 & 47,0 & 27,3 & 22,8 & 6,1 & 13,3 & 8,4 \\
\hline 11 & 80 & 28,8 & 8,8 & 5,9 & 61,9 & 1,7 & 2,2 & 1,3 & 93,5 & 45,7 & 22,9 & 16,7 & 5,2 & 10,2 & 5,4 \\
\hline 11 & 75 & 25,1 & 11,1 & 4,5 & 58.0 & 0,9 & 0,04 & 1,8 & 93,5 & 56,5 & 24,3 & 15,5 & 8,2 & 12,2 & 11,2 \\
\hline 12 & 85 & 13,8 & 1,7 & 3,4 & 12,4 & 1,7 & 0,4 & 0,3 & 42,6 & 16,1 & 4,9 & 7,0 & 0,9 & 3,7 & 2,4 \\
\hline 12 & 80 & 9,2 & 1,0 & 1,4 & 13,3 & 0,7 & 0,1 & 0,07 & 42,0 & 15,2 & 3,4 & 5,7 & 0,7 & 3,0 & 1,5 \\
\hline 12 & 75 & 6,9 & 1,1 & 0,9 & 11,9 & 0,4 & 0,002 & 0,05 & 43,6 & 18,0 & 3,6 & 4,6 & 1,1 & 2,6 & 2,9 \\
\hline 13 & 85 & 34,2 & 9,2 & 1,6 & 4,7 & 3,4 & 1,6 & 1,3 & 11,3 & 11,5 & 1,1 & 3,7 & 3,3 & 1,8 & 2,6 \\
\hline 13 & 80 & 30,7 & 7,5 & 0,9 & 6,7 & 1,9 & 0,7 & 0,4 & 14,9 & 15,1 & 1,0 & 4,1 & 3,1 & 2,1 & 2,8 \\
\hline 13 & 75 & 26,0 & 8,8 & 0,6 & 7,2 & 1,0 & 0,01 & 0,2 & 15,5 & 17,6 & 1,2 & 3,5 & 4,4 & 2,0 & 4,8 \\
\hline
\end{tabular}

Fonte: Variáveis 1, 2, 3, 10, 11, 12 e 13 - Censo Agropecuário dos estados em questão (1975, 1980 e 1985); Variável 4 - Anuário Estatístico do Brasil (1976, 1981, 1986 e 1987/88) e dados primários do IAA; Variável 5 - Anuário Estatístico do Brasil (1978, 1982, 1986 e 1987/88) e dados primários do IAA; Variável 6 - Anuário Estatístico do Brasil (1977, 1982, 1989); Variáveis 7 e 8 - dados primários do IAA; Variável 9 - Revista Visão - "Quem é Quem na economia brasileira" (1979, 1981 e 1986). 


\subsection{RESULTADOS OBTIDOS NA ANÁLISE FATORIAL}

A partir da matriz $\mathbf{X}$ procedeu-se à análise fatorial ${ }^{19}$ pelo método dos componentes principais, utilizando-se o Statical Analysis System (SAS). Salienta-se que não foram introduzidas estimativas preliminares das comunalidades, isto é, não houve alteração da diagonal principal da matriz das correlações. Ademais, para facilitar a interpretação dos fatores, foi feita uma rotação pelo método VARIMAX, mantendo a ortogonalidade entre eles (apesar da rotação alterar a contribuição de cada fator para explicar a variância dos 13 indicadores, a contribuição conjunta dos fatores permanece inalterada).

Como não existem critérios absolutos para decidir qual o número exato de fatores que devem ser extraídos, optou-se, neste trabalho, por considerar os quatro fatores cujas raízes características foram maiores do que 1. Este número de fatores escolhidos possibilita captar uma proporção satisfatória da variância total das variáveis originais, ou seja, 81,68\%, conforme pode ser visto na Tabela 19 .

Tabela 19 - Raízes características.

\begin{tabular}{cccccc}
\hline Itens & Fator 1 & Fator 2 & Fator 3 & Fator 4 & Fator 5 \\
\hline Raiz caracteristica & 6,0297 & 2,0818 & 1,3347 & 1,1728 & 0,8663 \\
Diferença & 3,9479 & 0,7471 & 0,1618 & 0,3066 & 0,4734 \\
Proporção & 0,4638 & 0,1601 & 0,1027 & 0,0902 & 0,0666 \\
Cumulativa & 0,4638 & 0,6240 & 0,7266 & 0,8168 & 0,8835 \\
\hline
\end{tabular}

Fonte: dados da pesquisa.

$\mathrm{Na}$ Tabela 20 são apresentadas as cargas fatoriais, ou seja, os coeficientes de correlação entre cada fator e cada uma das 13 variáveis após a rotação. As cargas fatoriais acima de 0,60, em valor absoluto, que mais fortemente associam-se com cada fator, estão destacadas em negrito. Embora a escolha deste percentual seja relativamente subjetiva, optou-se, neste estudo, por seguir trabalhos que também adotaram o valor de

\footnotetext{
${ }^{19}$ Foram realizados três grupos de análise fatorial: o primeiro grupo considerou os dados tal como apresentados na Tabela 18; o segundo grupo considerou que, para os casos onde não há informações para uma variável em determinado estado, tomou-se a média dos valores dos demais estados; e o terceiro grupo considerou a ponderação dos dados dos casos anteriores pela produção de cana-de-açúcar em cada estado (em 1975, 1980 e 1985). Em todos esses casos, a análise fatorial apresentou resultados coerentes com o que se esperava, ou seja, a evolução da agroindústria canavieira foi diferenciada entre estados. Contudo, os resultados da análise fatorial do primeiro grupo acima citado permite uma exposição mais rica dessa evolução diferenciada na agroindústria canavieira do Brasil. Por isso, apresentamos os resultados do primeiro grupo de análise fatorial (isto é, usando os dados da Tabela 18 sem ponderação, e considerando os valores referentes à zero como caracterizador da inexistência da variável tratada segundo fonte citada). A manutenção desses zeros implica uma peculiar interpretação do fator onde houve essa ocorrência.
} 
0,60 como referência - ver, por exemplo: Hoffmann (1992) e Figueiredo (1996). Na última coluna e linha da Tabela 20 destacam-se, respectivamente, o valor da comunalidade (que é a proporção da variância da variável que é "explicada" pelos quatro fatores), e as proporções da variância total "explicadas" por cada fator, após a rotação.

Tabela 20 - Cargas fatoriais de 4 fatores e comunalidades na análise fatorial dos 13 indicadores de modernização e caracterização da agroindústria canavieira em 14 estados do Brasil - 1975, 1980 e 1985.

\begin{tabular}{|c|c|c|c|c|c|}
\hline Variáveis & $\begin{array}{l}\text { Carga } \\
\text { fatorial } \\
\text { para F1 }\end{array}$ & $\begin{array}{l}\text { Carga } \\
\text { fatorial } \\
\text { para F2 }\end{array}$ & $\begin{array}{l}\text { Carga } \\
\text { fatorial } \\
\text { para F3 }\end{array}$ & $\begin{array}{l}\text { Carga } \\
\text { fatorial } \\
\text { para F4 }\end{array}$ & $\begin{array}{l}\text { Comunali- } \\
\text { dade }\end{array}$ \\
\hline 1 - \% de área de colheita da cana que usou defensivos & 0,86773 & $-0,21863$ & 0,08434 & 0,02767 & 0,808641 \\
\hline 2 - \% de área de colheita da cana que usou adubação & 0,85795 & 0,30107 & 0,07614 & 0,19436 & 0,870299 \\
\hline $\begin{array}{l}3 \text { - \% da área de colheita da cana que usou defensivos, } \\
\text { adubação, sementes selecionadas e compradas, irrigação }\end{array}$ & 0,62121 & 0,52662 & 0,11650 & 0,32330 & 0,781321 \\
\hline 4-Cana moida para açúcar (mil $t) \div$ número de usinas & 0,48994 & 0,23248 & 0,14651 & 0,72360 & 0,839147 \\
\hline $\begin{array}{l}5 \text { - Cana moida para álcool (mil t }) \div \text { número de } \\
\text { destilarias }\end{array}$ & 0,67946 & 0,18772 & 0,36733 & 0,03117 & 0,632810 \\
\hline 6 - Rendimento agricola da cana-de-açúcar $(\mathrm{kg} / \mathrm{ha})$ & 0,82161 & $-0,09007$ & 0,25803 & 0,13931 & 0,769141 \\
\hline 7 - Rendimento industrial do açúcar $(\mathrm{kg} / \mathrm{t})$ & 0,00586 & 0,03192 & 0,12016 & 0,94676 & 0,911844 \\
\hline 8 - Rendimento industrial do álcool (litros/t) & 0,72431 & 0,15719 & 0,11105 & 0,09008 & 0,569775 \\
\hline $\begin{array}{l}9 \text { - \% dos investimentos da amostragem das maiores } \\
\text { usinas e destilarias em termos de patrimônio líquido }\end{array}$ & 0,23384 & 0,02877 & 0,92375 & 0,10934 & 0,920769 \\
\hline $\begin{array}{l}10 \text { - \% da produção de cana-de-açúcar que é entregue à } \\
\text { indústria }\end{array}$ & 0,69523 & 0,42510 & 0,04714 & 0,03294 & 0,667363 \\
\hline $\begin{array}{l}11 \text { - total da área plantada com cana-de-açúcar no estado } \\
\div \text { total da área plantada com lavouras temporárias e } \\
\text { permanentes no estado }\end{array}$ & 0,08587 & 0,96215 & 0,15349 & 0,09564 & 0,965817 \\
\hline $\begin{array}{l}12 \text { - total da área plantada com cana-de-açúcar no estado } \\
\div \text { total da área explorada no estado }\end{array}$ & 0,08929 & 0,94749 & 0,15153 & 0,05750 & 0,931984 \\
\hline $\begin{array}{l}13 \text { - total da área plantada com cana-de-açúcar no estado } \\
\div \text { total da área plantada com cana no Brasil }\end{array}$ & 0,17678 & 0,37531 & 0,86788 & 0,15714 & 0,950019 \\
\hline \% da variância & 33,54 & 20,65 & 14,86 & 12,63 & $=$ \\
\hline
\end{tabular}

Fonte: dados da pesquisa.

Constata-se, para F1, sete variáveis cuja carga fatorial superaram a monta de 0,60 , quais sejam: as variáveis $1,2,3,5,6,8$ e 10. Neste contexto, as características das variáveis 1,2 e 3 (uso de insumos e técnicas modernas no segmento agrícola), 6 e 10 (rendimento agrícola da cana-de-açúcar e percentagem da produção de cana-de-açúcar que é entregue à indústria) sugerem ser F1 como um fator de medida de "modernização". Não obstante, este fator aparece ligado à produção alcooleira, haja vista o vínculo das variáveis 5 (cana moída para álcool sobre o número de destilarias) e 8 (rendimento industrial do álcool) com o setor álcool. 
Para F2, verifica-se sua positiva e forte correlação com as variáveis 11 e 12 , respectivamente, total da área plantada com cana-de-açúcar no estado sobre o total da área plantada com lavouras temporárias e permanentes no estado, e total da área plantada com cana-de-açúcar no estado sobre o total da área explorada no estado. Esse segundo fator associa-se com duas variáveis que retratam a especialização do estado na cultura canavieira, podendo-se dizer que F2 está medindo a intensidade da "especialização do estado na cultura canavieira".

O terceiro fator $(\mathrm{F} 3)$ guarda forte associação positiva com a variável 9 (\% dos investimentos da amostragem das maiores usinas e destilarias em termos de patrimônio líquido) e a variável 13 (total da área plantada com cana-de-açúcar no estado sobre o total da área plantada com cana-de-açúcar no Brasil). Pelas características das variáveis 9 e 13, o fator F3 pode ser denominado "importância do estado na cultura canavieira nacional".

Observa-se, portanto, que o fator F3 mostra a importância de cada estado dentro da cultura canavieira brasileira, enquanto o fator $\mathrm{F} 2$ mostra a importância em cada estado da cultura canavieira em relação às outras atividades agro-silvo-pastoris.

$\mathrm{O}$ fator $\mathrm{F} 4$ sugere algo como "rendimento e capacitação industrial do produto açúcar", posto as variáveis representativas 4 e 7 significarem, respectivamente, uma proxy da capacidade média de produção de açúcar e o rendimento industrial do açúcar.

Ainda com relação à Tabela 20, na última coluna encontra-se a comunalidade da cada variável, isto é, a proporção da variância de cada variável que é "explicada" pelos quatro fatores.

A Tabela 21 mostra os valores dos quatro fatores (F1, F2, F3 e F4) para os 14 estados do Brasil e para os anos de 1975, 1980 e 1985. Quanto ao fator F1, que indica "modernização" (sendo esta estreitamente relacionada ao produto álcool), observa-se, inicialmente, que todos os estados do País, à exceção do Paraná (que apresentou oscilação negativa entre 1980 e 1985), tiveram aumentos do fator F1 entre os três anos enfocados. Outrossim, independente desse comportamento, os estados do Rio de Janeiro, Bahia e Ceará ainda acusaram sinais negativos para os valores de F1 referentes à 1985. Numa outra direção, São Paulo, Paraná, Sergipe e Rio Grande do Norte foram os únicos 
estados a manterem-se com graus positivos de modernização ao longo dos três anos. Dentre os estados emergentes, o maior destaque foi Mato Grosso do Sul - cujos valores de F1 passaram a ser positivos e a superarem a unidade em 1980 e 1985 - seguido pelo Paraná, mesmo considerando o decréscimo verificado entre 1980 e 1985. O Rio Grande do Norte, que figura numa posição intermediária entre os estados tradicionais e os emergentes da agroindústria canavieira, surpreendeu pelos seus expressivos valores do fator F1 em 1980 e 1985.

Tabela 21 - Valores dos quatro fatores de modernização e caracterização da agroindústria canavieira em 14 estados do Brasil - 1975, 1980 e 1985.

\begin{tabular}{|c|c|c|c|c|c|c|c|c|c|c|c|c|}
\hline \multirow[t]{2}{*}{ Estado } & \multicolumn{3}{|c|}{ Fator F1 } & \multicolumn{3}{|c|}{ Fator F2 } & \multicolumn{3}{|c|}{ Fator F3 } & \multicolumn{3}{|c|}{ Fator F4 } \\
\hline & 1975 & 1980 & 1985 & 1975 & 1980 & 1985 & 1975 & 1980 & 1985 & 1975 & 1980 & 1985 \\
\hline SP & 0,383 & 0,909 & 1,286 & $-0,417$ & $-0,477$ & $-0,050$ & 3,326 & 3,465 & 3,142 & 0,203 & 0,333 & 0,342 \\
\hline MG & $-1,350$ & 0,019 & 0,418 & $-0,536$ & $-0,527$ & $-0,542$ & 0,320 & $-0,117$ & 0,106 & 0,177 & 0,841 & 0,627 \\
\hline ES & $-1,704$ & $-0,912$ & 0,554 & $-0,458$ & $-0,217$ & $-0,218$ & $-0,161$ & $-0,613$ & $-0,467$ & 0,431 & 0,595 & 0,323 \\
\hline $\mathrm{RJ}$ & $-0,646$ & $-0,233$ & $-0,225$ & 1,093 & 1,199 & 1,015 & $-0,249$ & $-0,347$ & $-0,298$ & 0,356 & 0,121 & 0,055 \\
\hline PR & 0,136 & 1,267 & 1,075 & $-0,768$ & -0,999 & $-0,915$ & $-0,609$ & $-0,721$ & $-0,284$ & 0,461 & 1,329 & 1,070 \\
\hline MS & $-0,881$ & 1,365 & 1,733 & $-0,469$ & $-0,446$ & $-0,472$ & 0,042 & $-0,497$ & $-0,179$ & $-2,995$ & $-3,250$ & $-3,417$ \\
\hline MT & $-1,281$ & 0,368 & 0,644 & $-0,715$ & $-0,810$ & $-0,855$ & $-0,069$ & $-0,678$ & $-0,576$ & $-0,687$ & 0,346 & 0,465 \\
\hline $\mathrm{Al}$ & $-0,115$ & 0,118 & 0,303 & 3,224 & 2,788 & 2,443 & $-0,053$ & $-0,066$ & 0,120 & $-0,469$ & $-0,078$ & 0,114 \\
\hline PE & $-0,378$ & 0,278 & 0,416 & 1,512 & 0,967 & 0,931 & 0,166 & 0,091 & 0,126 & 0,172 & 0,332 & 0,567 \\
\hline SE & 0,288 & 0,457 & 1,248 & $-0,076$ & $-0,177$ & $-0,257$ & $-0,829$ & $-0,869$ & $-0,849$ & 0,125 & 0,228 & 0,379 \\
\hline PB & $-0,402$ & 0,389 & 0,580 & 0,050 & $-0,156$ & $-0,340$ & $-0,315$ & $-0,415$ & $-0,124$ & $-0,173$ & $-0,260$ & $-0,188$ \\
\hline BA & $-1,838$ & $-1,368$ & $-0,358$ & $-0,627$ & $-0,800$ & $-0,574$ & 0,353 & 0,203 & $-0,149$ & $-0,030$ & $-0,405$ & $-0,381$ \\
\hline $\mathrm{RN}$ & 0,214 & 1,118 & 1,228 & $-0,448$ & $-0,333$ & $-0,388$ & $-0,616$ & $-0,887$ & $-0,842$ & 0,292 & 0,669 & 1,306 \\
\hline CE & $-2,405$ & $-1,889$ & $-0,809$ & $-0,557$ & $-0,386$ & $-0,211$ & 0,603 & 0,015 & $-0,200$ & $-0,191$ & 0,185 & 0,077 \\
\hline Média & $-0,71$ & 0,13 & 0,58 & 0,06 & $-0,03$ & $-0,03$ & 0,14 & $-0,10$ & $-0,03$ & $-0,17$ & 0,07 & 0,09 \\
\hline $\begin{array}{l}\text { Desvio } \\
\text { Padrão }\end{array}$ & 0,89 & 0,97 & 0,71 & 1,13 & 1,02 & 0,91 & 1,00 & 1,09 & 0,97 & 0,88 & 1,05 & 1,11 \\
\hline
\end{tabular}

Fonte: dados da pesquisa.

As análises da média e do desvio padrão do fator F1 confirmam que o processo de "modernização" da agroindústria canavieira, no período compreendido pelos anos de 1975, 1980 e 1985, foi, em termos nacional, progressivo, e em termos estaduais, diferenciado. A média do fator F1 passou de -0,71 em 1975, para 0,13 em 1980 e 0,58 em 1985. Considerando o desvio padrão nesta mesma relação temporal, observou-se, respectivamente, os valores de 0,89, 0,97 e 0,71. Este crescimento da dispersão dos valores de F1 entre 1975 e 1980, seguido por uma diminuição entre 1980 e 1985, evidencia o que de fato ocorreu nas duas fases do PROÁLCOOL: na fase de expansão "moderada" do PROÁLCOOL (1975 a 1979), a produção alcooleira baseou-se fundamentalmente em regiões tradicionais da agroindústria canavieira (causando diferenciação entre as regiões de produção); na fase de expansão "acelerada" desse Programa (1980 a 1985), registrou-se não só o fortalecimento da produção alcooleira em 
regiões tradicionais como a expansão dessa produção em regiões consideradas sem tradição neste setor (diminuindo a dispersão entre a produção). Portanto, o advento do PROÁLCOOL propiciou não só uma expansão da produção alcooleira em outros estados, como uma melhora "qualitativa" (dada pelos indicadores de "modernização" realçados pelo fator $\mathrm{F}_{1}$ ) nessa agroindústria, apesar dessa melhora não ter sido a preocupação maior dos produtores, pois os mesmos estavam sob um paradigma subvencionista.

A análise do fator F2 mostra a importância em cada estado da cultura canavieira em relação às outras atividades (agro-silvo-pastoris), isto é, a "especialização do estado na cultura canavieira". A análise da média do fator F2 sugere uma diminuição e posterior constância da "especialização na cultura canavieira", respectivamente, entre os anos de 1975 e 1980, e entre 1980 e 1985; enquanto entre os estados observou-se uma diminuição da dispersão.

Examinando a Tabela 21, constata-se intensidades e comportamentos distintos dos estados na especialização na cultura canavieira. Observa-se que estados como o Rio de Janeiro, Alagoas e Pernambuco, embora muito especializados na cultura canavieira, não foram aqueles que apresentaram os maiores coeficientes para o fator $\mathrm{F} 1$ (indicador da "modernização" da agroindústria canavieira). Quanto à diferença entre os estados, o fator F2 apontou Mato Grosso, Alagoas, Pernambuco, Sergipe e Paraíba com diminuição de especialização na cultura canavieira de 1975 para 1980, e de 1980 para 1985. Apesar dessa diminuição verificada em Alagoas, este estado apresentou os maiores valores para o fator F2. Ao revés, o Ceará foi o único estado a demonstrar aumento relativo durante esses três anos, embora tenha se mantido com valores negativos. Minas Gerais, Espírito Santo, Rio de Janeiro, Mato Grosso do Sul e Rio Grande do Norte oscilaram entre um aumento de F2 de 1975 para 1980, e uma diminuição de F2 de 1980 para 1985; sendo o Rio de Janeiro o único a apresentar-se com valores positivos para todos esses anos. São Paulo, Paraná e Bahia oscilaram entre uma diminuição de F2 de 1975 para 1980, e um aumento de F2 de 1980 para 1985.

O fator F3, "importância do estado na cultura canavieira nacional", evidencia dois importantes pontos: primeiro, a supremacia de São Paulo dentro do contexto da cultura canavieira nacional; segundo, na $1^{\underline{a}}$ fase do PROÁLCOOL essa supremacia aumentou e na $2^{\underline{a}}$ fase desse Programa essa supremacia diminuiu. Isto porque na $2^{\underline{a}}$ fase do 
PROÁLCOOL aumentou o número de empresários imitadores que adentraram nesse Programa. Vale destacar que alguns desses empresários imitadores foram tão modernos quanto os paulistas, vide os casos do Mato Grosso do Sul e Paraná, regiões de "transbordamento" da agroindústria canavieira paulista (alguns empresários desses dois estados supracitados mantêm, inclusive, seus escritórios em São Paulo).

Quanto a evolução diferenciada dos estados medida pelo fator F3, três comportamentos distintos podem ser realçados. $O$ primeiro relaciona-se com um decréscimo relativo entre os três anos enfocados; figuram, neste aspecto, os estados da Bahia e Ceará. O segundo tipo de comportamento, já colocado acima, diz respeito ao estado de São Paulo, que apresentou aumento de F3 entre 1975 e 1980, seguido de uma diminuição de F3 entre 1980 e 1985. Apesar dessa oscilação verificada em São Paulo, este estado apresentou os maiores valores para esse fator. $O$ terceiro tipo de comportamento corresponde a um decréscimo de F3 entre 1975 e 1980, e depois um acréscimo de F3 entre 1980 e 1985, verificado para os outros 11 estados (MG, ES, RJ, $\mathrm{PR}, \mathrm{MS}, \mathrm{MT}, \mathrm{AL}, \mathrm{PE}, \mathrm{SE}, \mathrm{PB}$ e RN). As análises da média e do desvio padrão do fator F3 mostram que a "importância do estado na cultura canavieira brasileira" diminuiu de 1975 para 1980, e aumentou de 1980 para 1985; enquanto a dispersão entre os estados aumentou e depois diminuiu. Esta última (diminuição da dispersão de F3 entre 1980 e 1985), deve-se à maior presença de empresários imitadores, principalmente em estados não tradicionais, na segunda fase do PROÁLCOOL.

Para o conjunto dos estados analisados, as evoluções positivas da média e do desvio padrão do fator F4 ("rendimento e capacitação industrial do produto açúcar") retratam que a modernização da agroindústria canavieira durante o PROÁLCOOL também estendeu-se à produção açucareira; contudo, sua dispersão continuou alta, ou seja, para o setor açucareiro não houve mudanças substanciais na localização geográfica da produção. Neste aspecto, embora São Paulo tenha relativamente tido destaque impar em F1 e F3, o mesmo não se verificou para F4. O bom desempenho no "rendimento e capacitação industrial do produto açúcar" foi, de modo geral, para os estados do Nordeste e para o Paraná e Minas Gerais; reafirmando a evolução diferenciada da agroindústria canavieira entre os estados. $\mathrm{O}$ fator $\mathrm{F} 4$ revelou seis estados com acréscimo relativo neste fator durante os três anos enfocados: São Paulo, Mato Grosso, Alagoas, Pernambuco, Sergipe e Rio Grande do Norte. Numa direção contrária, isto é, na ocorrência de um decréscimo relativo no fator $\mathrm{F} 4$ durante os três anos, observou-se os 
estados do Rio de Janeiro e Mato Grosso do Sul. Minas Gerais, Espírito Santo, Paraná e o Ceará oscilaram entre um aumento de F4 entre 1975 e 1980, seguido de uma diminuição de F4 entre 1980 e 1985. Paraíba e a Bahia oscilaram entre diminuição de F4 entre 1975 e 1980, seguido de um aumento de F4 entre 1980 e 1985. A aptidão alcooleira do Mato Grosso do Sul (valor zero para as variáveis 4 e 7) gerou os elevados valores negativos para $\mathrm{F} 4$, mostrando a posição inferior desse estado quanto ao fator avaliado.

Os resultados derivados da análise fatorial proposta vêm corroborar algumas colocações retratadas no capítulo 5. Verificou-se, por exemplo, que em 1975 a agroindústria canavieira já era diferenciada entre os estados brasileiros (vide os elevados valores dos fatores F1 e F3 para São Paulo em relação aos demais estados). Não obstante, o fator F1, que sugere "modernização", esteve estreitamente ligado ao produto álcool. O resultado disto é que o PROÁLCOOL realmente contribuiu não só para destacar perfomances como a de São Paulo no cenário nacional, como para melhorar o perfil geral da agroindústria canavieira. Novas regiões canavieiras, como Mato Grosso do Sul (que concentra-se basicamente na produção alcooleira) e Paraná, alcançaram um relativo destaque neste setor. Entretanto, é preciso frisar que o impacto do PROÁLCOOL sobre a modernização da agroindústria canavieira não foi homogêneo. Outros estados, como o Rio de Janeiro, Bahia e Ceará, apesar de melhorarem relativamente segundo o fator $\mathrm{F} 1$, ainda apresentaram sinais negativos para este fator em 1985. Para o caso dos estados que já tinham expressão no setor, o destaque foi para o Rio Grande do Norte, seja no fator $F 1$ ou no fator F4. Vale lembrar, conforme Schumpeter, que o processo de difusão de uma inovação não é homogêneo, ocorrendo, em termos da agroindústria canavieira, uma evolução diferenciada entre os estados.

Este estudo das medidas do grau de modernização da agroindústria canavieira no Brasil, mediante técnica de análise fatorial (método dos componentes principais), restringiu-se, pela dificuldade de obtenção de dados mais recentes, aos anos de 1975, 1980 e 1985, e aos 14 estados supracitados. Faz-se premente, portanto, uma análise mais atualizada (para as safras 1985/1986 e 1995/1996) do comportamento dos estados representativos da agroindústria canavieira, ressaltando, dessa vez, as estratégias tecnológicas das firmas, assunto este relativo à próxima seção. Nessa análise procurar-seá ressaltar não apenas a evolução diferenciada entre estados, mas, também, dentro de cada estado. 


\section{AS ESTRATÉGIAS TECNOLÓGICAS DAS FRMAS}

A análise das estratégias tecnológicas das firmas da agroindústria canavieira constitui-se em um importante auxílio para a investigação da evolução diferenciada ocorrida na agroindústria canavieira. Neste contexto, o método escolhido para esta verificação consiste na aplicação de questionários junto a uma amostra de usinas e destilarias do Brasil. ${ }^{20}$

Dentre os objetivos comumente propostos neste tipo de estudo está a idéia de que a análise de uma determinada fração do universo possibilitará a ampliação dos conhecimentos acerca desse universo. Todavia, cuidados especiais devem ser tomados com relação à escolha das unidades para a implementação desse tipo de estudo, além de se ter em mente as limitações que existem quanto a generalização dos resultados obtidos.

Ciente destes aspectos, neste capítulo efetua-se um detalhamento de como foram aplicados os questionários junto às usinas e destilarias da agroindústria canavieira, procurando-se obter informações como: quais foram as estratégias tecnológicas adotadas pelas usinas e destilarias? Ou, como os problemas técnicos do processo produtivo foram resolvidos? Como observações pontuais a respeito do questionário formulado (vide apêndice C), ressalta-se que duas safras foram analisadas (1985/86 e 1995/96). Outrossim, verifica-se como foram aproveitados os subprodutos derivados da cana-deaçúcar posto que, diante da crise da agroindústria canavieira, um maior número de subprodutos passou a ganhar expressão econômica. Além dessas relações, também destacam-se os questionamentos sobre a relação Estado-agroindústria canavieira e Pesquisa \& Desenvolvimento-agroindústria canavieira. Portanto, a análise de uma amostra possível (mas, representativa) de usinas e destilarias da agroindústria canavieira

20 Como referência para a obtenção de dados mediante uso do questionário utilizou-se, fundamentalmente, os trabalhos de Boyd \& Westfall (1964), Gil (1991) e Rocha Júnior (1994). 
irá constituir-se em um importante auxilio para a investigação da evolução diferenciada neste setor, complementando, desta forma, os capítulos 5 e 6 do presente trabalho.

\subsection{A TÉCNICA DE PESQUISA}

Esta pesquisa baseia-se em um tipo de amostragem não probabilística, que poderia ser rotulada como amostragem possivel. Visando ampliar a investigação da evolução diferenciada da agroindústria canavieira, também em termos de firmas, foram selecionados 6 estados representativos desse setor, quais sejam: São Paulo, Alagoas, Pernambuco, Minas Gerais, Rio de Janeiro e Paraná. Esses estados detinham, na safra 1994/95, 88,5\% das unidades que produziram açúcar, 86,9\% das unidades que produziram açúcar e álcool, 73,2\% das unidades que produziram álcool; sendo esses estados responsáveis por $93,7 \%, 94,0 \%$ e $86,9 \%$ da produção nacional de açúcar, álcool anidro e álcool hidratado, respectivamente (Carvalho, 1996).

Para obtenção de dados mediante técnica de interrogação, optou-se pela aplicação de um questionário enviado via correio. $\mathrm{Na}$ construção das questões (vide apêndice $\mathrm{C}$ ) procurou-se traduzir os objetivos desta tese em três blocos de perguntas: política setorial; política tecnológica; e, âmbito da produção (perfazendo um total de 15 perguntas). As perguntas referentes à produção questionaram duas safras: 1985/86 e 1995/96.

Após a redação do questionário efetuou-se, durante a primeira quinzena do mês de março de 1997, um pré-teste desse questionário, objetivando não só o seu aperfeiçoamento como também a sua boa aceitabilidade junto aos respondentes.

Tendo assegurado uma maior precisão técnica com a realização do pré-teste, no mês de abril de 1997 foram enviados questionários (via correio) para todas as unidades produtivas que realizaram a safra 1995/96 nos 6 estados aqui considerados, o que resultou no envio de 269 questionários (a base de informações usada para esta finalidade foi o Guia dos Produtores de Açúcar e Álcool - Região Centro-Sul - safra 95/96 e Guia dos Produtores de Açúcar e Álcool - Região Norte-Nordeste - safra 95/96).

O primeiro lote de questionários preenchidos e devolvidos (via Correio) foi recebido em maio de 1997 e correspondeu a 22,5\% do número de questionários enviados. Entretanto, os estados de Pernambuco e Alagoas não conseguiram atingir boa 
representatividade amostral. Decidiu-se, então, uma visita - ainda no mês de maio de 1997 - aos dois estados mencionados para proporcionar maiores esclarecimentos sobre a importância e finalidade desta pesquisa.

Fruto dessas viagens houve um segundo lote de questionários preenchidos e recebidos via correio durante o mês de junho. Como resultado final, do total de questionários enviados 6 não chegaram ao seu destino, por motivo de encerramento de atividades da usina ou destilaria ("não foi encontrado o destinatário", segundo notificação do correio). Não obstante, o índice de respostas obtido superou os $35 \%$, valor este considerado satisfatório para os objetivos do presente estudo. Segundo Gil (1991), para esta técnica de pesquisa (questionário enviado pelo correio) não se consegue mais do que 20 ou $25 \%$ de devoluções.

\subsection{OS RESULTADOS OBTIDOS}

Dos 263 questionários efetivamente enviados às usinas e destilarias dos estados de São Paulo (142), Minas Gerais (27), Paraná (27), Rio de Janeiro (12), Pernambuco (27) e Alagoas (28), foram respondidos 93 questionários, ou seja, 35,4\% do universo pesquisado. A distribuição percentual dos questionários respondidos, por estados, foi a seguinte: $31,0 \%$ para São Paulo, 33,3\% para Minas Gerais, 48,1\% para o Paraná, 33,3\% para o Rio de Janeiro, 51,9\% para Pernambuco e 32,1\% para Alagoas (Tabela 22).

Tabela 22 - Representatividade da amostra pesquisada em termos das produções estaduais de álcool anidro e hidratado, açúcar e empregos gerados (total da amostra pesquisada sobre os totais estaduais de cada item).

\begin{tabular}{lrrrrrrc}
\hline $\begin{array}{c}\text { Esta- } \\
\text { do }\end{array}$ & $\begin{array}{c}\text { Uni- } \\
\text { verso }\end{array}$ & $\begin{array}{c}\text { Amos } \\
\text { tra }\end{array}$ & $\begin{array}{c}\text { Amostra/ } \\
\text { universo } \\
(\%)\end{array}$ & $\begin{array}{c}\text { Produção de } \\
\text { álcool hidratado } \\
(\%)\end{array}$ & $\begin{array}{c}\text { Produção de } \\
\text { alcool anidro } \\
(\%)\end{array}$ & $\begin{array}{c}\text { Produção de } \\
\text { açúcar } \\
(\%)\end{array}$ & $\begin{array}{c}\text { Total de empregos } \\
\text { gerados* } \\
(\%)\end{array}$ \\
\hline SP & 142 & 44 & 31,0 & 41,2 & 48,9 & 42,3 & 40,4 \\
MG & 27 & 9 & 33,3 & 49,5 & 48,7 & 75,5 & 43,0 \\
PR & 27 & 13 & 48,1 & 46,7 & 54,6 & 57,0 & 47,9 \\
RJ & 12 & 4 & 33,3 & 60,9 & 100 & 58,8 & 33,0 \\
PE & 27 & 14 & 51,9 & 53,9 & 28,0 & 51,7 & 52,3 \\
AL & 28 & 9 & 32,1 & 43,1 & 51,5 & 40,2 & 41,1 \\
\hline Média & - & - & - & 49,2 & 55,3 & 54,3 & 43,0 \\
\hline
\end{tabular}

Fonte: dados da pesquisa.

*= empregos no setor administrativo, industrial e agrícola. 
A Tabela 22 também destaca a representatividade da amostra pesquisada em termos das produções estaduais de álcool hidratado, álcool anidro e açúcar, e empregos gerados pelo setor na safra 1995/96. Constata-se que, na média, as amostras pesquisadas por estados apresentaram percentuais superiores a $43,0 \%$ para os itens mencionados.

Uma análise preliminar das firmas pesquisadas evidencia que em Alagoas a maioria das unidades pertencem a uma cooperativa, sendo que o mesmo não se verificou no Rio de Janeiro, Pernambuco, Minas Gerais e Paraná. Em São Paulo esta distribuição cooperada e não cooperada - apresentou 50\% das unidades como pertencentes a uma cooperativa (Tabela 23). Particularmente para São Paulo, a existência de firmas vinculadas à COPERSUCAR pode traduzir-se numa maior vantagem em termos de apoio de $\mathrm{P} \& \mathrm{D}$, posto o elevado nível de pesquisa aplicada desenvolvida por esta Cooperativa (vide capítulo 4 ).

Tabela 23 - Distribuição percentual das firmas pesquisadas da agroindústria canavieira quanto à situação institucional e tipo de unidade (posição no 10 semestre de 1997).

\begin{tabular}{|c|c|c|c|c|c|c|c|c|c|c|c|c|}
\hline \multirow[t]{2}{*}{ Itens e especificações } & \multicolumn{2}{|c|}{ SP } & \multicolumn{2}{|c|}{$\mathrm{MG}$} & \multicolumn{2}{|c|}{$\mathrm{PR}$} & \multicolumn{2}{|c|}{$\mathrm{RJ}$} & \multicolumn{2}{|c|}{$\mathrm{PE}$} & \multicolumn{2}{|c|}{$\mathrm{AL}$} \\
\hline & $\mathrm{n}^{\mathrm{o}}$ & $\%$ & $\mathrm{n}^{\mathrm{o}}$ & $\%$ & no & $\%$ & no & $\%$ & $\mathrm{n}$ 은 & $\%$ & no & $\%$ \\
\hline Cooperada & 22 & 50,0 & 4 & 44,4 & 4 & 30,8 & - & 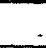 & . & - & 5 & 55,6 \\
\hline Não cooperada & 21 & 47,7 & 5 & 55,6 & 7 & 53,8 & 4 & 100 & 13 & 92,9 & 4 & 44,4 \\
\hline Não respondeu este item & 1 & 2,3 & - & - & 2 & 15,4 & - & & 1 & 7,1 & - & $=$ \\
\hline Usinas & 1 & 2,3 & . & & - & . & - & & - & - & 1 & 11,1 \\
\hline Usinas com destilarias anexas & 29 & 65,9 & 6 & 66,7 & 7 & 53.8 & 4 & 100 & 13 & 92.9 & 6 & 66,7 \\
\hline Destilarias autônomas & 14 & 31,8 & 3 & 33,3 & 6 & 46.2 & - & & 1 & 7,1 & 2 & 22,2 \\
\hline
\end{tabular}

Fonte: dados da pesquisa.

Através da Tabela 23 constata-se ainda a maior representatividade de usinas com destilarias anexas vis-à-vis as usinas e destilarias autônomas. No caso de uma crise do álcool ou do açúcar, a maior probabilidade de sobrevivência vai para aquela empresa que puder diversificar sua produção (conforme observado no item 5.3.3, a partir de 1986 até a safra 1991/92, dos estabelecimentos produtores de açúcar e/ou álcool que deixaram de funcionar no Brasil, $82,1 \%$ das unidades desativadas correspondiam a destilarias autônomas e apenas $17,9 \%$ correspondiam a usinas com destilaria anexa).

Uma tendência comum observada para os seis estados foi o aumento, entre as safras 1985/86 e 1995/96, da participação de cana própria em detrimento da cana advinda de fornecedores (Tabela 24). Adaptando as idéias de Cochrane (1979) para essa 
contextualização, verifica-se que o processo de concentração da posse de terras é uma tônica presente também para a agroindústria canavieira, sobretudo às expensas dos fornecedores de cana.

Tabela 24 - Fornecimento de cana-de-açúcar (valores médios) - safras 1985/86 e $1995 / 96$.

\begin{tabular}{lcccccc}
\hline \multicolumn{1}{c}{ Itens e especificações } & SP & MG & PR & RJ & PE & AL \\
\hline Cana - fornecedor (85/86) & 44,6 & 33,6 & 38,3 & 62,7 & 53,9 & 51,9 \\
Cana - própria (85/86) & 55,4 & 66,4 & 61,7 & 37,3 & 46,1 & 48,1 \\
Cana - fornecedor (95/96) & 35,8 & 20,5 & 21,8 & 52,0 & 44,1 & 41,5 \\
Cana - própria (95/96) & 64,2 & 79,5 & 78,2 & 48,0 & 55,9 & 58,5 \\
\hline
\end{tabular}

Fonte: dados da pesquisa.

Outra constatação sobre o comportamento das firmas refere-se à evolução da produção efetiva e da capacidade de produção dos estabelecimentos pesquisados. A despeito da relativa falta de dados de pelo menos uma das safras enfocadas, nota-se que não houve diminuição da produção efetiva e da capacidade de produção de açúcar. Ao contrário, para o álcool, boa parte das firmas indicaram queda na produção desse produto (Tabela 25). Isto confirma a gravidade da situação conjuntural porque passa o álcool.

Tabela 25 - Distribuição percentual das firmas pesquisadas da agroindústria canavieira quanto a evolução da produção efetiva e capacidade de produção entre as safras 1985/86 e 1995/96.

\begin{tabular}{|c|c|c|c|c|c|c|}
\hline A çúcar & $\mathrm{SP}$ & $\mathrm{MG}$ & PR & $\mathrm{RJ}$ & $\mathrm{PE}$ & $\mathrm{AL}$ \\
\hline Não informou dados de pelo menos uma safra & 40,0 & 16,7 & 85,7 & - & 15,4 & 14,3 \\
\hline Aumentou a produção efetiva e a capacidade de produção & 43,3 & 33,3 & - & 50,0 & 38,5 & 28,6 \\
\hline Aumentou a produção efetiva - constante a capacidade & 13,3 & 33,3 & 14,3 & 50,0 & 23,1 & 28,6 \\
\hline Aumentou a produção efetiva - não informou a capacidade & 3,3 & - & - & - & 7,7 & 28,6 \\
\hline Aumentou a capacidade - não informou a produção efetiva & - & 16,7 & - & - & - & - \\
\hline Diminuiu a produção efetiva - constante a capacidade & - & - & - & - & - & - \\
\hline Diminuiu a produção efetiva - aumentou a capacidade & - & - & - & - & - & - \\
\hline Diminuiu a produção efetiva - não infonnou a capacidade & - & - & - & - & - & - \\
\hline Diminuiu a produção efetiva e a capacidade de produção & - & - & - & - & - & - \\
\hline Constante a produção efetiva e a capacidade de produção & - & - & - & - & 15,4 & - \\
\hline Alcool & SP & $\mathrm{MG}$ & PR & $\mathrm{RJ}$ & $\mathrm{PE}$ & $\overline{\mathrm{AL}}$ \\
\hline Não informou dados de pelo menos uma safra & 7,0 & 22,2 & 38,5 & - & 28,6 & 12,5 \\
\hline Aumentou a produção efetiva e a capacidade de produção & 37,2 & 22,2 & 46,2 & - & 21,4 & 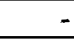 \\
\hline Aumentou a produção efetiva - constante a capacidade & 11,6 & 33,3 & - & 25,0 & 28,6 & 12,5 \\
\hline Aumentou a produção efetiva - não informou a capacidade & 11,6 & - & 7,7 & - & 7,1 & 25,0 \\
\hline Aumentou a capacidade - não informou a produção efetiva & - & 11,1 & - & - & - & 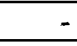 \\
\hline Diminuiu a produção efetiva - constante a capacidade & 16,3 & 11,1 & 7,7 & 25,0 & - & 25,0 \\
\hline Diminuiu a produção efetiva - aumentou a capacidade & 7,0 & - & - & - & 7,1 & - \\
\hline Diminuiu a produção efetiva - não informou a capacidade & 2,3 & - & - & - & - & 25,0 \\
\hline Diminuiu a produção efetiva e a capacidade de produção & 2,3 & - & - & 50,0 & - & - \\
\hline Constante a produção efetiva e a capacidade de produção & 4,7 & - & - & - & 7,1 & - \\
\hline
\end{tabular}

Fonte: dados da pesquisa. 


\subsubsection{AVALIAÇÃO DAS FIRMAS SOBRE AS POLÍTICAS SETORIAIS}

A distribuição percentual das firmas pesquisadas sobre o assunto "extinção do Instituto do Açúcar e do Álcool (IAA) e do PLANALSUCAR" (Tabela 26) evidenciou, de modo geral, que a maioria foi favorável à extinção do IAA, exceção feita para os estados de Pernambuco (cuja histórica relação com o IAA por si só justifica tal posição) e Rio de Janeiro. Alagoas, que também fôra alvo de políticas protecionistas desse Instituto, ao contrário de Pernambuco, apresentou maior posição de favorabilidade e indiferença quanto à extinção do IAA. Sobre a extinção do PLANALSUCAR, a maioria dos pesquisados foram desfavoráveis. Nota-se, portanto, que além de ocorrer uma diferença entre estados no que respeita à extinção desses órgãos, verifica-se também uma diferença dentro de cada estado.

Tabela 26 - Distribuição percentual das firmas pesquisadas da agroindústria canavieira quanto à extinção do Instituto do Açúcar e do Álcool (IAA) e do PLANALSUCAR (posição no 10 semestre de 1997).

\begin{tabular}{|c|c|c|c|c|c|c|c|}
\hline \multicolumn{2}{|c|}{ Itens e especificações } & $\mathrm{SP}$ & $\mathrm{MG}$ & $\mathrm{PR}$ & $\mathrm{RJ}$ & $\mathrm{PE}$ & $\mathrm{AL}$ \\
\hline \multirow{4}{*}{$\begin{array}{l}\text { Posiçāo da } \\
\text { firma quanto } \\
\text { à extinçāo do } \\
\text { IAA }\end{array}$} & favorável & 63,6 & 55,6 & 46,2 & 25,0 & 28,6 & 44,4 \\
\hline & indiferente & 22,7 & - & 23,1 & 25,0 & 7,1 & 33,3 \\
\hline & desfavorável & 13,6 & 44,4 & 30,8 & 50,0 & 50,0 & 22,2 \\
\hline & não respondeu & - & - & - & - & 14,3 & - \\
\hline \multirow{4}{*}{$\begin{array}{l}\text { Posiçāo da } \\
\text { firma quanto } \\
\text { à extinçāo do } \\
\text { PLANALSUCAR }\end{array}$} & favorável & 15,9 & 33,3 & - & - & - & - \\
\hline & indiferente & 29,5 & - & 15,4 & - & 7,1 & - \\
\hline & desfavorável & 52,3 & 55,6 & 84,6 & 100 & 85,7 & 100 \\
\hline & não respondeu & 2,3 & 11,1 & - & - & 7,1 & - \\
\hline \multirow{4}{*}{$\begin{array}{l}\text { Posiçāo da firma } \\
\text { Cooperada sobre } \\
\text { a extinçāo do } \\
\text { IAA }\end{array}$} & favorável & 54,5 & 25,0 & - & - & - & 20,0 \\
\hline & indiferente & 31,8 & $\Sigma$ & 50,0 & - & - & 40,0 \\
\hline & desfavorável & 13,6 & 75,0 & 50,0 & - & - & 40,0 \\
\hline & não respondeu & - & - & - & - & - & - \\
\hline \multirow{4}{*}{$\begin{array}{l}\text { Posição da firma } \\
\text { não Cooperada } \\
\text { sobre a extinçāo } \\
\text { do IAA }\end{array}$} & favorável & 71,4 & 100 & 85,7 & 25,0 & 30,8 & 75,0 \\
\hline & indiferente & 14,3 & - & - & 25,0 & 7,7 & 25,0 \\
\hline & desfavorável & 14,3 & - & 14,3 & 50,0 & 46,2 & - \\
\hline & não respondeu & - & - & - & - & 15,4 & - \\
\hline \multirow{4}{*}{$\begin{array}{l}\text { Posiçāo da firma } \\
\text { Cooperada sobre } \\
\text { a extinçāo do } \\
\text { PLANALSUCAR } \\
\end{array}$} & favorável & 31,8 & 25,0 & - & - & - & - \\
\hline & indiferente & 9,1 & - & - & - & - & - \\
\hline & desfavorável & 54,5 & 50,0 & 100 & - & - & 100 \\
\hline & não respondeu & 4,7 & 25,0 & - & - & - & - \\
\hline \multirow{4}{*}{$\begin{array}{l}\text { Posição da firma } \\
\text { não Cooperada } \\
\text { sobre a extinçāo do } \\
\text { PLANALSUCAR }\end{array}$} & favorável & - & 40,0 & - & - & - & - \\
\hline & indiferente & 52,4 & - & 14,3 & - & 15,4 & - \\
\hline & desfavorável & 47,6 & 60,0 & 85,7 & 100 & 84,6 & 100 \\
\hline & não respondeu & - & - & - & - & - & - \\
\hline
\end{tabular}

Fonte: dados da pesquisa. 
Os diferentes posicionamentos adotados por cada estado e suas diferentes reações internas podem ser melhor evidenciadas quando se cruzam as informações sobre a extinção do IAA e PLANALSUCAR com a condição da firma ser cooperada ou não. Neste contexto, observa-se que: em Minas Gerais a maioria das firmas cooperadas foram desfavoráveis à extinção do IAA; no Paraná a metade das firmas cooperadas apresentaram tal posição de desfavorabilidade; enquanto que em Alagoas e São Paulo essa proporção foi equivalente a $40 \%$ e $13,6 \%$, respectivamente (Tabela 26). Em São Paulo, a maioria das firmas cooperadas foram favoráveis à extinção do IAA ( $54,5 \%$ na posição de favorabilidade e $31,8 \%$ na posição de indiferença). Isto denota uma maior reinvidicação dessas firmas paulistas por um mercado mais desregulamentado, ou, em termos da hipótese que norteia o presente trabalho, significa dizer que há uma posição de afastamento com relação ao paradigma subvencionista. Outrossim, esta reinvidicação por um mercado mais desregulamentado fica ainda mais evidente quando se observa a posição das firmas não cooperadas, conquanto a maioria dos pesquisados de Minas Gerais, Paraná, Alagoas e São Paulo foram favoráveis à extinção do IAA. Para o Rio de Janeiro e Pernambuco o maior percentual verificado permaneceu na posição de desfavorabilidade à extinção do IAA.

Considerando-se a extinção do PLANALSUCAR, para o caso das firmas cooperadas, observou-se que em Minas Gerais e São Paulo houve percentuais igual ou pouco superior a $50 \%$ direcionados para uma posição de desfavorabilidade à extinção do PLANALSUCAR (Tabela 26). Em Alagoas e Paraná este reclame foi mais contundente, atingindo $100 \%$ das firmas cooperadas que foram desfavoráveis à extinção desse órgão. Para o caso das firmas não cooperadas, a maioria dos pesquisados dos estados do Rio de Janeiro, Alagoas, Pernambuco, Paraná e Minas Gerais foram desfavoráveis à extinção do PLANALSUCAR. Apenas em São Paulo observou-se um percentual maior $(52,4 \%)$ para a posição de indiferença quanto à extinção desse órgão de pesquisa. Isto retrata, de modo geral, a bem aparelhada infra-estrutura tecnológica situada no estado de São Paulo (como destacado no capítulo 4), a ponto de relativa fração dos produtores paulistas não darem importância para a extinção do PLANALSUCAR, fato este não verificado nos outros estados. Neste aspecto é importante associar essas colocações com a questão do paradigma tecnológico, pois uma reinvidicação por um órgão de pesquisa voltado para a agroindústria canavieira, independente do estado apresentar ou não uma infra-estrutura 
tecnológica autônoma, retrata a maior preocupação das firmas com um padrão de solução de problemas tecno-econômicos selecionados.

Sobre as políticas setoriais (Tabela 27), houve uma relativa concordância entre os respondentes quanto ao caráter inadequado da política de preços para a cana-de-açúcar e da política de crédito. Sobre a posição da firma no que se refere à política de preços para o açúcar houve um percentual considerável (vis-à-vis as outras políticas de preços) daqueles que a consideraram adequada, exceção feita para Pernambuco. Sobre a política de preços para o álcool verificou-se um elevado percentual daqueles que consideraram essa política inadequada, exceção feita para o estado do Paraná onde 53,8\% dos respondentes consideraram-na adequada.

Tabela 27 - Distribuição percentual das firmas pesquisadas da agroindústria canavieira quanto à política setorial (posição no 10 semestre de 1997).

\begin{tabular}{|c|c|c|c|c|c|c|c|}
\hline \multicolumn{2}{|c|}{ Itens e especificações } & SP & $\mathrm{MG}$ & PR & $\mathrm{RJ}$ & $\mathrm{PE}$ & $\mathrm{AL}$ \\
\hline \multirow{3}{*}{$\begin{array}{l}\text { Posição da firma } \\
\text { quanto à política de } \\
\text { preços para a cana }\end{array}$} & inadequada & 81,8 & 88,9 & 76,9 & 75,0 & 85,7 & 66,7 \\
\hline & adequada & 13,6 & 11,1 & 23,1 & 25,0 & 14,3 & 33,3 \\
\hline & não respondeu & 4,5 & - & - & - & - & - \\
\hline \multirow{3}{*}{$\begin{array}{l}\text { Posição da firma } \\
\text { quanto à política de } \\
\text { preços p/o açúcar }\end{array}$} & inadequada & 54,5 & 55,6 & 38,5 & 50,0 & 92,8 & 44,4 \\
\hline & adequada & 34,1 & 22,2 & 53,8 & 25,0 & 7,1 & 55,6 \\
\hline & não respondeu & 11,4 & 22,2 & 7,7 & 25,0 & - & - \\
\hline \multirow{3}{*}{$\begin{array}{l}\text { Posição da firma } \\
\text { quanto à política de } \\
\text { preços p/o álcool }\end{array}$} & inadequada & 90,9 & 100,0 & 46,2 & 75,0 & 92,8 & 88,9 \\
\hline & adequada & 6,8 & - & 53,8 & 25,0 & 7,1 & - \\
\hline & não respondeu & 2,3 & - & - & - & - & 11,1 \\
\hline \multirow{6}{*}{$\begin{array}{l}\text { Posição } \\
\text { da } \\
\text { firma } \\
\text { quanto } \\
\text { ao } \\
\text { endividamento } \\
\text { setorial } \\
\end{array}$} & $\begin{array}{l}\text { necessário para } \\
\text { sobrevivência }\end{array}$ & 47,7 & 44,4 & 46,2 & 75,0 & 57,1 & 66,7 \\
\hline & p/crescimento & 13,6 & 22,2 & 23,1 & - & 7,1 & 22,2 \\
\hline & indiferente & - & 11,1 & - & - & 7,1 & - \\
\hline & nào necessáno* & 31,8 & 11,1 & 7,7 & 25,0 & 7,1 & 11,1 \\
\hline & não respondeu & 4,5 & - & 7,7 & - & 21,4 & - \\
\hline & oura resposta ${ }^{* *}$ & 2,3 & 11,1 & 15,4 & - & - & - \\
\hline \multirow{3}{*}{$\begin{array}{l}\text { Posição da } \\
\text { firma quanto à } \\
\text { politica de crédito } \\
\end{array}$} & inadequada & 84,1 & 77,8 & 92,3 & 100 & 92,8 & 88,9 \\
\hline & adequada & 11,4 & 22,2 & 7,7 & - & 7,1 & 11,1 \\
\hline & não respondeu & 4,5 & - & - & - & - & - \\
\hline
\end{tabular}

Fonte: dados da pesquisa.

* = para o item "não necessário, por quê", foram citadas colocações referentes à dois blocos de idéias: sobre políticas do governo federal e questão conjuntural; e, sobre a eficiência administrativa e tecnológica.

** = para o item "outra resposta", foram citadas colocações referentes à insatisfação geral quanto ao atual nível de endividamento da agroindústria canavieira.

Cada estado revelou um conjunto de opiniões sobre o posicionamento da firma quanto ao endividamento setorial. Contudo, o maior percentual concentrou-se na 
especificação que considera o endividamento setorial como "necessário para a sobrevivência do setor" (Tabela 27). Sobre o complemento da resposta "não necessário, por quê" (pertinente ao endividamento setorial), verificaram-se colocações referentes à dois blocos de idéias: sobre políticas do governo federal e questão conjuntural, no qual o argumento é de que endividamento decorreu de uma política inadequada que poderia ter sido evitada; e, sobre a eficiência administrativa e tecnológica, onde o endividamento advém da má gestão dos negócios e da falta de avanço tecnológico.

Cruzando as informações das Tabelas 26 e 27, tem-se a Tabela 28. A insatisfação geral com as políticas setoriais foi proporcionalmente maior em Pernambuco, onde 71,4\% do total das firmas pesquisadas alegaram o caráter inadequado das políticas de preços e crédito para o setor. Seguem-se-lhe, Minas Gerais, Rio de Janeiro, São Paulo, Paraná e Alagoas (Tabela 28). Nos estados do Rio de Janeiro, Pernambuco, Minas Gerais e São Paulo, as firmas não cooperadas foram aquelas que mais evidenciaram essa insatisfação; no Paraná isto ocorreu com maior veemência para as firmas cooperadas; e, em Alagoas, houve um equilibrio entre cooperadas e não cooperadas.

Tabela 28 - Firmas que declararam ser inadequadas as políticas de preços para a cana, açúcar e álcool, e de crédito; sua relação com o fato da firma ser cooperada ou não, e com a posição de favorabilidade, indiferença ou desfavorabilidade quanto à extinção do IAA (posição no 10 semestre de 1997).

\begin{tabular}{cc|c|c|c|c}
\hline \multirow{2}{*}{ Estado } & \% de firmas que & \multicolumn{3}{c}{ Das firmas que declararam ser inadequadas as políticas setoriais } \\
\cline { 5 - 6 } & $\begin{array}{c}\text { declararam ser } \\
\text { inadequadas as } \\
\text { políticas sobre } \\
\text { o total de firmas }\end{array}$ & $\begin{array}{c}\text { \% das firmas } \\
\text { que são } \\
\text { cooperadas }\end{array}$ & $\begin{array}{c}\text { \% das tirmas } \\
\text { que não são } \\
\text { cooperadas }\end{array}$ & $\begin{array}{c}\text { \% das firmas que } \\
\text { foram indiferentes ou } \\
\text { favoráveis à extinção } \\
\text { do IAA }\end{array}$ & $\begin{array}{c}\text { \% das firmas que } \\
\text { foram desfavoráveis à } \\
\text { extinção do IAA }\end{array}$ \\
\hline SP & 47,7 & 47,6 & 52,4 & 76,2 & 23,8 \\
MG & 55,6 & 40,0 & 60,0 & 80,0 & 20,0 \\
PR & 38,5 & 60,0 & 40,0 & 60,0 & 40,0 \\
RJ & 50,0 & - & 100 & - & 100 \\
PE & 71,4 & - & 100 & 40,0 & 50,0 \\
AL & 22,2 & 50,0 & 50,0 & 100 & - \\
\hline
\end{tabular}

Fonte: dados da pesquisa.

Obs.: Uma firma pernambucana que declarou as políticas como inadequadas não assumiu posição quanto à extinção do IAA.

Ao se comparar essa insatisfação geral com a posição sobre a extinção do IAA, constata-se, para Alagoas, Minas Gerais, São Paulo e Paraná, um maior percentual das firmas pesquisadas que se colocam numa posição de indiferença ou favorabilidade sobre a extinção do IAA (Tabela 28). Tal fato confirma, também para uma maioria de firmas descontentes com as políticas de preços e crédito, uma posição favorável ou de 
indiferença no que diz respeito a extinção do IAA, exceção para Pernambuco e Rio de Janeiro. Logo, além das diferenças entre os estados em relação aos aspectos supracitados, verificou-se posicionamentos distintos de firmas dentro dos próprios estados.

\subsubsection{ATIVIDADE DE P\&D}

A distribuição percentual das firmas pesquisadas no tocante à política tecnológica (Tabela 29) revelou que a atividade de P\&D é proporcionalmente mais executada pelas firmas situadas nos estados do Paraná, São Paulo e Alagoas. As principais áreas de atuação da $\mathrm{P} \& \mathrm{D}$ ressaltadas pelas firmas da agroindústria canavieira foram: agronômica (novas variedades de cana-de-açúcar), industrial (tecnologia industrial de produção de açúcar e álcool), motomecanização e RH (Recursos Humanos).

Tabela 29 - Distribuição percentual das firmas pesquisadas da agroindústria canavieira quanto à política tecnológica - P\&D - e resolução de problemas técnicos (posição no 1으 semestre de 1997).

\begin{tabular}{|c|c|c|c|c|c|c|c|}
\hline \multicolumn{2}{|c|}{ Itens e especificações } & $\mathrm{SP}$ & $\mathrm{MG}$ & PR & $\mathrm{RJ}$ & $\mathrm{PE}$ & $\mathrm{AL}$ \\
\hline \multirow{3}{*}{$\begin{array}{l}\text { Realiza } \\
\text { Pesquisa \& } \\
\text { Desenvolvimento }\end{array}$} & $\sin$ & 56,8 & 22,2 & 69,2 & 25,0 & 42,9 & 55,5 \\
\hline & em termos & 18,2 & 33,3 & 15,4 & - & - & 22,2 \\
\hline & não & 25,0 & 44,4 & 15,4 & 75,0 & 57,1 & 22,2 \\
\hline \multirow{9}{*}{$\begin{array}{l}\text { Como os } \\
\text { problemas } \\
\text { técnicos do } \\
\text { processo } \\
\text { produtivo } \\
\text { são resolvidos }\end{array}$} & $\begin{array}{l}1 \text { - pelos proprios } \\
\text { técnicos }\end{array}$ & 9,1 & - & 23,1 & - & 14,3 & 44,4 \\
\hline & 2 - por terceiros & 4,5 & 22,2 & - & 25,0 & 21,4 & - \\
\hline & 3-pela Cooperativa & 9,1 & - & - & - & - & - \\
\hline & 4 - outra forna $* * *$ & 2,3 & - & 7,7 & - & - & - \\
\hline & Combinação 1 e 2 & 56,8 & 66,7 & 46,2 & 50,0 & 64,3 & 22,2 \\
\hline & Combinação 1 e 3 & 4,5 & 11,1 & - & - & - & 11,1 \\
\hline & Combinação 1 e $4^{* *}$ & - & - & 15,4 & - & - & - \\
\hline & Combinaçào 1,2 e 3 & 9,1 & - & 7,7 & - & - & 22,2 \\
\hline & Combinação 1,2 e $4^{*}$ & 4,5 & - & - & 25,0 & - & - \\
\hline
\end{tabular}

Fonte: dados da pesquisa.

*** = para 0 item "outra forma", foram citados: "transferência de tecnologia" (SP); e, "assessoria" (PR).

** = para a "combinação 1 e 4", foram citadas: "centro de pesquisa em convênio com a UFPR" (PR); e, "através de consultorias" (PR).

* = para a "combinação 1, 2 e 4", foram citadas: "universidade" (SP); "transferência de tecnologia" (SP); e, "intercâmbio com outras unidades produtoras" (RJ).

Novamente é preciso considerar que além das diferenças entre os estados, houve também diferenças entre as firmas dentro do estado. Em São Paulo, por exemplo, relativamente mais firmas fazem P\&D do que em Minas Gerais; sendo que, dentro de São Paulo, 56,8\% das firmas fazem P\&D e $25 \%$ não o fazem (Tabela 29). As firmas que 
realizam $\mathrm{P} \& \mathrm{D}$, ou que se baseiam na $\mathrm{P} \& \mathrm{D}$ desenvolvida pelas cooperativas, demonstram a importância do paradigma tecnológico como forma de definir o que é relevante para uma situação mais concorrencial.

Cabe lembrar que o elevado número de firmas que desenvolvem atividade de P\&D no estado de São Paulo vai de encontro com a maior concentração técnicaeconômica em torno desse estado, fato este relatado no capítulo 5 deste trabalho. Alagoas surgiu como evidência em termos de $\mathrm{P} \& \mathrm{D}$ devido à existência de um grupo de empresários dispostos a investir nesta área e em decorrência da herança deixada pelo extinto PLANALSUCAR na região. No Paraná, os produtores de cana-de-açúcar, localizados sobremaneira em áreas mais dinâmicas desse estado (região norte), vêm sendo "(...) incentivados a desenvolverem sempre novas experiências com a cana, na busca de maior lucratividade, e de rendimentos crescentes na produção, mesmo quando o cultivo se processa em áreas pequenas" (Guerra, 1995, p.92).

Os problemas técnicos do processo produtivo foram resolvidos, em boa parte, pela "combinação" feita entre os próprios técnicos dos estabelecimentos e por terceiros (Tabela 29). Um relativo percentual das firmas pesquisadas de Alagoas, Paraná, Pernambuco e São Paulo demonstraram resolver seus problemas unicamente através dos seus técnicos, o que demonstra capacidade de auto-suficiência. Outra constatação importante diz respeito ao relativo percentual de resolução de problemas técnicos feitos pelas cooperativas em São Paulo, onde se encontra a destacada COPERSUCAR. Sabese, conforme exposição feita no capítulo 4, que boa parte das firmas vinculadas a COPERSUCAR adotam estratégias semelhantes à estratégia ofensiva descrita por Freeman (1974), isto é, intensiva em P\&D e com elevado nível de pesquisa aplicada.

Quanto aos principais fatores que barram a adoção de novas tecnologias (pergunta no10 do questionário, vide apêndice C), o item que obteve maior expressão para as firmas pesquisadas dos seis estados (para os itens já pré-determinados no questionário) ${ }^{21}$ foi o item C - "para outros subprodutos da agroindústria canavieira (por exemplo, bagaço de cana) ainda não há um mercado consolidado a ponto de incentivar o

\footnotetext{
${ }^{21}$ Esses itens foram: (A), "os empresários da agroindústria canavieira preferem não assumir riscos"; (B), "o mercado dessa agroindústria, bastante regulamentado pelo Estado, não favorece a inovação"; (C), "para outros subprodutos da agroindústria canavieira (por exemplo, bagaço de cana) ainda não há um mercado consolidado a ponto de incentivar o surgimento de novas tecnologias"; (D), "excesso de oferta de cana-de-açúcar"; (E), "grande distância entre os centros de pesquisa e a unidade produtora".
} 
surgimento de novas tecnologias". Daí o fato de fração das firmas pesquisadas direcionar esforços para a atividade de P\&D. Outro item que alcançou expressivo destaque nos estados de São Paulo, Minas Gerais e Paraná, foi o item B - "o mercado dessa agroindústria, bastante regulamentado pelo Estado, não favorece a inovação". Verificase, desta forma, a coerência do posicionamente apresentado pelos estados de São Paulo, Minas Gerais e Paraná no tocante à extinção do IAA - onde 63,6\%, 55,6\% e 46,2\%, respectivamente, foram favoráveis à extinção do IAA (vide Tabela 26). O "excesso de oferta de cana-de-açúcar" (item D) obteve destaque no Rio de Janeiro e Pernambuco. Estes dois estados apresentaram metade das firmas com posicionamento desfavorável à extinção do IAA - órgão este que tinha como uma de suas atribuições manter o equilíbrio interno entre as safras anuais de cana-de-açúcar e o consumo dos seus principais produtos (conforme exposto no capítulo 3). A "grande distância entre os centros de pesquisa e a unidade produtora" (item E) obteve destaque em Alagoas e Minas Gerais. Esta colocação, quando comparada com a P\&D, confirma um importante ponto: a coexistência de produtores modernos com atrasados. Especialmente em Alagoas, enquanto um grupo de usineiros revela a existência de P\&D em suas atividades internas, outro grupo reclama da grande distância entre os centros de pesquisa e suas unidades produtoras. Não obstante, as menores médias para o item E foram justamente para São Paulo, estado com a maior concentração técnica-econômica da agroindústria canavieira, e para o Paraná, que apresentou bom desempenho na análise fatorial comentada no capítulo anterior.

Ainda sobre os principais fatores que barram a adoção de novas tecnologias, apareceram em "outros itens" as seguintes colocações: falta de recursos financeiros - em Minas Gerais, Alagoas, São Paulo e Paraná; falta de política para o setor - em Minas Gerais, Alagoas, Paraná, São Paulo e Pernambuco; e, questões de âmbito conjuntural e localização geográfica não privilegiada - em São Paulo, Paraná e Pernambuco.

Cruzando as informações das firmas que realizam $P \& D$, com a questão da unidade produtiva ser cooperada ou não, comprova-se o fato de relativa fração das firmas cooperadas de Alagoas, Minas Gerais ${ }^{22}$, São Paulo e Paraná basearem a P\&D unicamente naquela desenvolvida pela Cooperativa (Tabela 30). Outrossim, São Paulo foi o único estado a apresentar unidades cooperadas que, além de contarem com a P\&D

\footnotetext{
${ }^{22}$ Faz-se necessário frisar que, dentre as firmas pesquisadas em Minas Gerais, uma encontra-se filiada a uma cooperativa paulista, baseando-se a P\&D nessa Cooperativa.
} 
realizada pela Cooperativa, desenvolvem sua própria P\&D. No Paraná e em São Paulo verificou-se a menor fração de firmas cooperadas que não contam com nenhuma P\&D. Sobre a relação P\&D e firmas não cooperadas, constatou-se uma proporção elevada de firmas não cooperadas que não realizam a $\mathrm{P} \& \mathrm{D}$, isto para os estados do Rio de Janeiro, Pernambuco e Minas Gerais. Vale lembrar que para os casos de Pernambuco e Rio de Janeiro observaram-se apenas firmas não cooperadas. Em se tratando de firmas não cooperadas que realizam a $\mathrm{P} \& \mathrm{D}$, o destaque foi para os estados de Paraná, Pernambuco, Alagoas e São Paulo. A partir da relação P\&D e unidade produtiva cooperada ou não, novamente pode-se constatar não apenas a distinção entre os estados, mas a diferença dentro de cada estado - veja o caso de Pernambuco que, dentre as suas firmas não cooperadas, apresentou $42,9 \%$ das firmas que realizam $P \& D$ e $50 \%$ que não realizam P\&D.

Tabela 30 - Relação entre a firma ser cooperada ou não e a realização de P\&D (valores em \%) - posição no 10 semestre de 1997.

\begin{tabular}{lcccccc}
\hline Itens e especificações & SP & MG & PR & RI & PE & AL \\
\hline $\begin{array}{l}\text { Cooperada que realiza P\&D } \\
\text { independente da Cooperativa }\end{array}$ & 20,5 & - & 15,4 & - & - & 22,2 \\
\hline $\begin{array}{l}\text { Cooperada que baseia a P\&D } \\
\text { exclusivamente na Cooperativa }\end{array}$ & 18,2 & 22,2 & 15,4 & - & - & 22,2 \\
\hline $\begin{array}{l}\text { Cooperada que baseia a P\&D } \\
\text { na Cooperativa e que realiza } \\
\text { sua própria P\&D }\end{array}$ & 4,5 & - & - & - & - & - \\
\hline $\begin{array}{l}\text { Cooperada que não realiza } \\
\text { P\&D }\end{array}$ & 6,8 & 22,2 & - & - & - & 11,1 \\
\hline $\begin{array}{l}\text { Não cooperada que realiza sua } \\
\text { própria P\&D }\end{array}$ & 29,5 & 22,2 & 46,2 & 25,0 & 42,9 & 33,3 \\
\hline $\begin{array}{l}\text { Não cooperada que não realiza } \\
\text { P\&D }\end{array}$ & 18,2 & 22,2 & 7,7 & 75,0 & 50,0 & 11,1 \\
\hline $\begin{array}{l}\text { Não registrou se a firma é } \\
\text { cooperada ou não. }\end{array}$ & 2,3 & - & 15,4 & - & 7,1 & - \\
\hline
\end{tabular}

Fonte: dados da pesquisa.

Obs.: Uma unidade de Minas Gerais colocou a opção "em termos", referindo-se aos convênios feitos com a COPERSUCAR, Universidade Federal de Viçosa e Universidade Federal de São Carlos. Contudo, esta firma não é cooperada.

\subsubsection{MUDANÇA TÉCNICA E DA PRODUÇÃO}

Constatou-se que o uso de irrigação com água não atingiu nos estados do Paraná, São Paulo e Minas Gerais a mesma importância que nos estados de Pernambuco, Alagoas e Rio de Janeiro, isto devido às próprias condições edafo-climáticas das regiões 
retratadas (Tabela 31). Outrossim, constatou-se uma evolução favorável no uso da maioria das tecnologias agrícolas enfocadas, isto no âmbito geral (considerando o somatório e a distribuição ponderada das especificações em termos de áreas utilizadas por exemplo, no item "uso de irrigação com vinhaça" em São Paulo para a safra 1985/86, $15,9 \%$ dos respondentes situarem-se nas especificações "não utilizada" e "não respondeu", na safra 1995/96 esse percentual diminuiu, correspondendo a 6,8\%; vê-se, ainda, que o crescimento observado concentrou-se na especificação "40 a 60\% da área").

Tabela 31 - Distribuição percentual das firmas pesquisadas da agroindústria canavieira quanto à adoção de tecnologias agrícolas - safras 1985/86 e 1995/96.

\begin{tabular}{|c|c|c|c|c|c|c|c|c|c|c|c|c|c|}
\hline \multicolumn{2}{|c|}{ Itens e especificações } & \multicolumn{2}{|c|}{$\mathrm{SP}$} & \multicolumn{2}{|c|}{$\mathrm{MG}$} & \multicolumn{2}{|c|}{ PR } & \multicolumn{2}{|c|}{$\mathrm{RJ}$} & \multicolumn{2}{|c|}{$\mathrm{PE}$} & \multicolumn{2}{|c|}{$\mathrm{AL}$} \\
\hline \multirow{6}{*}{$\begin{array}{l}\text { Uso } \\
\text { de irrigação } \\
\text { com } \\
\text { água }\end{array}$} & $100 \%$ da área & $\therefore$ & 2,3 & . & & - &. &. & & . & - &. & \\
\hline & 70 a $90 \%$ da área & . & . & . & . & - & - & 25,0 & . & . & . & . & 22,2 \\
\hline & 40 a $60 \%$ da área &. & 2,3 & $\therefore$ & $=$ & - & - & . & 75,0 & 7,1 & 14,3 & 11,1 & 33,3 \\
\hline & $<40 \%$ da área & 15.9 & 29.5 & 33,3 & 44,4 & - & . & 50,0 & 25,0 & 71,4 & 71,4 & 66,7 & 33,3 \\
\hline & não utilizada & 63.6 & 52.3 & 55,6 & 44,4 & 84,6 & 84,6 & 25,0 & - & 21,4 & 14,3 & 22,2 & 11,1 \\
\hline & não respondeu & 20,5 & 13,6 & 11,1 & 11,1 & 15,4 & 15,4 & - & - & - & - & & - \\
\hline \multirow{6}{*}{$\begin{array}{l}\text { Uso } \\
\text { de irrigação } \\
\text { com } \\
\text { vinhaça }\end{array}$} & $100 \%$ da área & 2.3 & 2.3 & - & . &. & . &. &. &. &. & . & - \\
\hline & 70 a $90 \%$ da área & . & . & - &. & - & &. & 25,0 & . &. & . & - \\
\hline & 40 a $60 \%$ da área & 15,9 & 38,6 & 11,1 & 22,2 & 7.7 & 15,4 & - & 75,0 & 7,1 & 21,4 & $\therefore$ & 11,1 \\
\hline & $<40 \%$ da área & 65,9 & 52,3 & 77,8 & 66,7 & 38,5 & 61,5 & 50,0 & . & 71,4 & 71,4 & 66,7 & 55,6 \\
\hline & não utilizada & 9,1 & 2.3 & - & - & 46,2 & 23,1 & 50,0 & - & 21,4 & 7,1 & 33,3 & 33,3 \\
\hline & não respondeu & 6.8 & 4.5 & 11,1 & 11,1 & 7,7 & - & - & - & - & - & - & - \\
\hline \multirow{6}{*}{$\begin{array}{l}\text { Uso de } \\
\text { defensivo }\end{array}$} & $100 \%$ da área & 54,5 & 61,4 & 55,6 & 44.4 & 23,1 & 61,5 & 25,0 & 25,0 & 42,9 & 50,0 & & 11,1 \\
\hline & 70 a $90 \%$ da área & 22,7 & 29,5 & 11,1 & 33,3 & 69,2 & 38,5 & 25,0 & 50,0 & 28,6 & 35,7 & 33,3 & 88,9 \\
\hline & 40 a $60 \%$ da área & 11,4 & 4.5 & 11,1 & 11,1 & . & . & 25,0 &. & 21,4 & 14,3 & 66,7 & . \\
\hline & $<40 \%$ da área & . & 2.3 & 11.1 & - & . & . & 25.0 & 25,0 & 7,1 & - & . & . \\
\hline & não utilizada & 4.5 & - & . & - & . &. & & . & . &. & . & . \\
\hline & não respondeu & 6,8 & 2.3 & 11,1 & 11,1 & 7,7 & - & & - & - & $\therefore$ & - & $\therefore$ \\
\hline \multirow{6}{*}{$\begin{array}{l}\text { Uso de } \\
\text { adubação }\end{array}$} & $100 \%$ da área & 72,7 & 81.8 & 55,6 & 66,7 & 38,5 & 84,6 & 25,0 & 25,0 & 85,7 & 92,9 & 88,9 & 88,9 \\
\hline & 70 a $90 \%$ da área & 18.2 & 11,4 & 33,3 & 22,2 & 53,8 & 15,4 & 25,0 & 50,0 & 14,3 & 7,1 & 11,1 & 11,1 \\
\hline & 40 a $60 \%$ da àrea & 2,3 & 2,3 & - & - & . & . & 50,0 & 25,0 & . & - & . & . \\
\hline & $<40 \%$ da área & . & 2,3 & . &. & . &. &. &. & . &. & . & - \\
\hline & não utilizada & 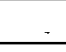 & . & & 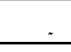 & . & . & - &. & . & - & . & \\
\hline & não respondeu & 6.8 & 2.3 & 11,1 & 11.1 & 7.7 & $=$ & - & - & . & - & 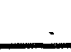 & - \\
\hline \multirow{6}{*}{$\begin{array}{l}\text { Uso de sementes } \\
\text { compradas }\end{array}$} & $100 \%$ da área & 6,8 & 4.5 & - & - & . & 7,7 & - & . & 7,1 & 7,1 & . & - \\
\hline & 70 a $90 \%$ da área & $\sim$ & 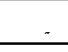 & 22.2 & 11,1 & . & - &. & - & 7,1 & 7,1 & . & - \\
\hline & 40 a $60 \%$ da a area & 4,5 & 2.3 & - & 11,1 & - & 30,8 & . & - & 7,1 & 7,1 & - & . \\
\hline & $<40 \%$ da ärea & 40,9 & 43.1 & 33,3 & 55,6 & 53,8 & 23,1 & 50,0 & 50,0 & 42,9 & 42,9 & 44,4 & 44,4 \\
\hline & não utilizada & 29.5 & 29,5 & 33,3 & 11,1 & 30,8 & 23,1 & 50,0 & 50,0 & 21,4 & 21,4 & 55,6 & 44,4 \\
\hline & não respondeu & 18.2 & 20,5 & 11,1 & 11,1 & 15,4 & 15,4 & . & & 14,3 & 14,3 & & 11,1 \\
\hline
\end{tabular}

Fonte: dados da pesquisa. 
Para os itens "uso de defensivos" e "uso de adubação", cabe destacar suas expressivas utilizações nos estados de Alagoas, Pernambuco e Rio de Janeiro - onde não houve percentagens para as especificações "não utilizada" e "não respondeu". Quanto ao "uso de irrigação com vinhaça", todos os estados pesquisados apresentaram evoluções favoráveis.

O item "sementes compradas" não apresentou evolução favorável em São Paulo, apresentando constância nos estados do Rio de Janeiro, Pernambuco e Alagoas. No Paraná houve evolução favorável em quase todos os itens em realce, exceção somente para o caso do "uso de irrigação com água", cuja ocorrência não foi observada.

Verifica-se um problema com o item "sementes compradas". Sabe-se que a maioria das usinas e destilarias usam "sementes selecionadas", sendo poucos os estabelecimentos que compram este tipo de produto, cujo comportamento sazonal é evidente, ou seja, apenas no período de lançamento de uma variedade inovadora é que ocorrem as maiores procuras e conseqüentemente a compra.

No tocante às tecnologias mecânicas adotadas (Tabela 32), verificou-se em várias ocasiões uma forte tendência para o maior uso de máquinas próprias "combinadas" com de terceiros (exceção feita para o estado do Paraná, onde o avanço ocorreu majoritariamente no uso de máquinas próprias; Pernambuco, nos casos relativos ao "uso de máquinas para o plantio" e "uso de arado mecânico"; e Alagoas, no "uso de máquinas para o plantio" e "uso de caminhões para o transporte"). Sobre a evolução no uso das tecnologias mecânicas (somatório das especificações "uso próprio", "de terceiro" e "próprio/terceiro"), observou-se em São Paulo, Paraná e Pernambuco um progresso em todos os itens estudados (máquinas para plantio, colheita, arado e caminhões). De modo geral, Minas Gerais e Rio de Janeiro não apresentaram evoluções favoráveis no uso das tecnologias mecânicas (somatório do uso próprio, de terceiros e próprio/terceiro); permanecendo sem variações relativas entre as safras 1985/86 e 1995/96, embora valha colocar em destaque os expressivos percentuais obtidos nos itens em estudo (exceção feita para o "uso de máquinas para a colheita")

Quanto à adoção de tecnologias mecânicas, especialmente de máquinas para o plantio e colheita, o quadro mostrou-se relativamente promissor para os estados pesquisados do Nordeste, embora Alagoas tenha acusado uma queda percentual no "uso 
de máquinas para a colheita". Tal colocação confirma o que expõe Santos (1996, p.64), isto é, alguns produtores do Norte/Nordeste, assim como seus pares do Centro-Sul, progrediram na tecnologia aplicada ao cultivo: "já nos anos 80, a transferência da cultura da cana de áreas acidentadas para áreas mais planas e acessíveis às máquinas, mesmo que menos férteis, se fazia importante e crescente, consolidando-se na década de $90^{\prime \prime}$.

Tabela 32 - Distribuição percentual das firmas pesquisadas da agroindústria canavieira quanto à adoção de tecnologias mecânicas - safras 1985/86 e 1995/96.

\begin{tabular}{|c|c|c|c|c|c|c|c|c|c|c|c|c|c|}
\hline \multirow{2}{*}{\multicolumn{2}{|c|}{ Itens e especificações }} & \multirow{2}{*}{\multicolumn{2}{|c|}{ SP }} & \multirow{2}{*}{\multicolumn{2}{|c|}{$\mathrm{MG}$}} & \multirow{2}{*}{\multicolumn{2}{|c|}{ PR }} & \multirow{2}{*}{\multicolumn{2}{|c|}{$\mathrm{RJ}$}} & \multirow{2}{*}{\multicolumn{2}{|c|}{ PE }} & \multirow{2}{*}{\multicolumn{2}{|c|}{$\overline{A L}$}} \\
\hline & & & & & & & & & & & & & \\
\hline \multirow{5}{*}{$\begin{array}{l}\text { Uso de } \\
\text { máquinas para } \\
\text { o plantio }\end{array}$} & usou própria & 54,5 & 43,2 & 88,9 & 33,3 & 61.5 & 84,6 & 75,0 & 75,0 & 50,0 & 64,3 & 88,9 & 100 \\
\hline & usou de terceiro & 2,3 & $\dot{\Delta}$ & . & 11,1 & . & 7,7 & . & - & - & - & 11,1 & - \\
\hline & usou proppria/terceiro & 2,3 & 20,5 & - & 44,4 & 23,1 & 7,7 & 25,0 & 25,0 & 21,4 & 14,3 & - & $=$ \\
\hline & não respondeu & 6,8 & 4,5 & 11,1 & 11,1 & 7.7 & - & - & . & 14,3 & 7,1 & & - \\
\hline & não usou & 34,1 & 31.8 & & & 7,7 & & - & - & 14,3 & 14,3 & & $\therefore$ \\
\hline \multirow{5}{*}{$\begin{array}{l}\text { Uso de } \\
\text { máquinas para } \\
\text { a colheita }\end{array}$} & usou própria & 31,8 & 43,2 & 44,4 & 33,3 & 23,1 & 30,8 & 25,0 & - & 28,6 & 28,6 & 44,4 & 22,2 \\
\hline & usou de terceiro & 2,3 & . & - & 11,1 & $\therefore$ & . & . & . & - & . & - & . \\
\hline & usou própria/terceiro & 2,3 & 13,7 & - & - & . & - & 25,0 & 50,0 & 35,7 & 50,0 & . & 11,1 \\
\hline & não respondeu & 11,4 & 9,1 & 11.1 & 11,1 & 7,7 & . & . & - & 7,1 & - & 11,1 & 22,2 \\
\hline & não usou & 52,3 & 34,1 & 44.4 & 44.4 & 69.2 & 69,2 & 50,0 & 50,0 & 28,6 & 21,4 & 44,4 & 44,4 \\
\hline \multirow{5}{*}{$\begin{array}{l}\text { Uso de } \\
\text { arado } \\
\text { mecânico }\end{array}$} & usou própria & 70,5 & 72,7 & 88,9 & 55,6 & 38.5 & 84,6 & 75,0 & 75,0 & 78,6 & 85.7 & 77,8 & 77,8 \\
\hline & usou de terceiro & 2,3 & 2,3 & - & 11,1 & - & 7,7 & . & - & . & - & - & . \\
\hline & usou propria/terceiro & 6,8 & 13,7 & - & 22,2 & 7.7 & - & 25,0 & 25,0 & - & - & . & - \\
\hline & não respondeu & 9,1 & 2,3 & 11,1 & 11,1 & 7,7 & . & . & . & 14,3 & 7,1 & - & 22,2 \\
\hline & não usou & 11,4 & 9,1 & - & - & 46.2 & 7,7 & - & - & 7,1 & 7,1 & 22,2 & \\
\hline \multirow{5}{*}{$\begin{array}{l}\text { Uso de } \\
\text { caminhões para } \\
\text { o transporte }\end{array}$} & usou propria & 47,7 & 25,0 & 77,8 & 22,2 & 15,4 & 61,5 & 50,0 & 25,0 & 28,6 & 21,4 & 11,1 & 22,2 \\
\hline & usou de terceiro & 6,8 & 13,7 & 11,1 & 22,2 & 38.5 & . & - & . & 14,3 & 14,3 & . & . \\
\hline & usou propria/terceiro & 38.6 & 59,1 & 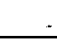 & 44,4 & 38,5 & 38,5 & 50,0 & 75,0 & 50,0 & 64,3 & 88,9 & 77,8 \\
\hline & não respondeu & 6,8 & 2,3 & 11,1 & 11,1 & 7,7 & - & - & . & 7,1 & - & . & - \\
\hline & não usou & . & . & . & - & - & . & - & $=$ & 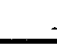 & $=$ & . & $=$ \\
\hline
\end{tabular}

Fonte: dados da pesquisa.

Sobre o aproveitamento dos subprodutos da cana-de-açúcar (Tabela 33), ficou patente a evolução dos percentuais verificados em todos os itens (bagaço, vinhoto, etc) para São Paulo (neste caso, efetuou-se o somatório de todas as especificações, com exceção dos termos "descartado" e "nenhuma resposta"). Nos demais estados o destaque foram os expressivos percentuais obtidos no aproveitamento dos subprodutos, exceção para os casos das "leveduras" em Minas Gerais e no Paraná, e "óleo fusel" em Alagoas.

Alguns itens isolados, como o gás carbônico, com pouca margem de uso na safra 1985/86, apenas obteve ocorrência em São Paulo. Porém, na safra 1995/96 houve uma 
sensível melhora com relação a este item, com ocorrência não só em São Paulo, mas em Minas Gerais, Paraná e Pernambuco. O melaço foi o "outro subproduto" que apareceu nesta amostra, isto apenas em São Paulo.

Tabela 33 - Aproveitamento de subprodutos - safras 1985/86 e 1995/96 - (valores em $\%)$.

\begin{tabular}{|c|c|c|c|c|c|c|c|c|c|c|c|c|c|}
\hline \multirow{2}{*}{\multicolumn{2}{|c|}{ Itens e especificações }} & \multirow{2}{*}{\multicolumn{2}{|c|}{$\mathrm{SP}$}} & \multirow{2}{*}{\multicolumn{2}{|c|}{$\mathrm{MG}$}} & \multirow{2}{*}{\multicolumn{2}{|c|}{$\mathrm{PR}$}} & \multirow{2}{*}{\multicolumn{2}{|c|}{$\mathrm{RJ}$}} & \multirow{2}{*}{\multicolumn{2}{|c|}{$\mathrm{PE}$}} & \multirow{2}{*}{\multicolumn{2}{|c|}{$\mathrm{AL}$}} \\
\hline & & & & & & & & & & & & & \\
\hline \multirow{9}{*}{$\begin{array}{l}\text { Aprovei- } \\
\text { tamento } \\
\text { do } \\
\text { Bagaço }\end{array}$} & 1. Venda & 11,4 & 11,4 & + & - & - & . &. & . & 21,4 & 14,3 & 11,1 & 11,1 \\
\hline & 2 - Uso intensivo na produção & 27.3 & 25,0 & 77,8 & 77,8 & 30,8 & 76,9 & 100 & 100 & 50,0 & 50,0 & 55,6 & 55,6 \\
\hline & 3. Uso parcial na produção & 4,5 & 2.3 & - & - & 23,1 & 7,7 & $\therefore$ & . & $\therefore$ & . & 11,1 & + \\
\hline & 4-Em fase de pesquisas & $\dot{.}$ & . & $\therefore$ & - & - & . & - & . & . & . & - & - \\
\hline & 5-Descartado & 2.3 & 2,3 & . & . & 30,8 & - &. & . & . & . & 11,1 & 11,1 \\
\hline & Combinação 1 e 2 (v-uip) & 20,5 & 22.7 & 11,1 & 11,1 & - & - & - & . & 14,3 & 28,6 & - & 11,1 \\
\hline & Combinação l e 3 (v-upp) & 22,7 & 27,3 & $\cdot$ & . & 7,7 & 7,7 & - & - & 7,1 & 7,1 & - & 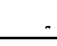 \\
\hline & Combinação 3 e 4 (upp-pes) & 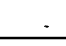 & 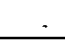 & . & . & 7,7 & 7,7 & . & . &. & $\therefore$ &. & - \\
\hline & Nenhuma resposta & 11.4 & 9.1 & 11,1 & 11,1 & - & - & - & - & 7,1 & 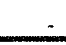 & 11,1 & 11,1 \\
\hline \multirow{5}{*}{$\begin{array}{l}\text { Aprovei- } \\
\text { tamento } \\
\text { do } \\
\text { Vinhoto }\end{array}$} & 2 - Uso intensivo na produção & 72,7 & 86,4 & 66,7 & 66,7 & 23,1 & 69,2 & 50,0 & 75,0 & 42,9 & 78,6 & 33,3 & 66,7 \\
\hline & 3 - Uso parcial na produção & 11,4 & 6.8 & 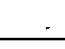 & - & 53,8 & 7,7 & $\therefore$ & - & 28,6 & - & 33,3 & 11,1 \\
\hline & 4. Em fase de pesquisas & - & . & . & - & - & 7,7 &. & . & 14,3 & . & $\dot{.}$ & . \\
\hline & 5. Descartado & 2,3 & . & 11.1 & 11,1 & 23,1 & 15,4 & 50,0 & 25,0 & - & $=$ & 11,1 & 11,1 \\
\hline & Nenhuma resposta & 13.6 & 6.8 & 22,2 & 22,2 & $\therefore$ & - & - & - & 14,3 & 21,4 & 22,2 & 11,1 \\
\hline \multirow{8}{*}{$\begin{array}{l}\text { Aprovei- } \\
\text { tamento } \\
\text { do Óleo } \\
\text { fusel }\end{array}$} & 1 - Venda & 81,8 & 84,1 & 88,9 & 88,9 & 53,8 & 61,5 & 50,0 & 50,0 & 42,9 & 35,7 & 22,2 & 22,2 \\
\hline & 2 - Uso intensivo na produção & . & 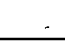 & - & - & - & . & - & . & 14,3 & 14,3 & - & - \\
\hline & 3. Uso parcial na produção &. & 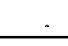 & + & 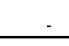 & - & - & 25,0 & 25,0 & 7,1 & 7,1 & - & - \\
\hline & 4-Em fase de pesquisas & . & . & . & & + & 30,8 & - & - & 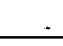 & 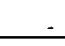 & - & - \\
\hline & 5 - Descartado & 2.3 & 2,3 & - & . & 46,2 & 7,7 & 25,0 & - & 7,1 & 7,1 & 11,1 & 11,1 \\
\hline & Combinação 1 e 2 (v-uip) & - & . & - & - & - & . & - & . & . & 7,1 & . & . \\
\hline & Combinação 1 e 3 (v-upp) & - & 2,3 & - & 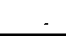 & - & - & - & . & . & . & . & - \\
\hline & Nenhuma resposta & 15,9 & 11,4 & 11,1 & 11.1 & - & - & - & 25,0 & 28,6 & 28,6 & 66,7 & 66,7 \\
\hline \multirow{5}{*}{$\begin{array}{l}\text { Aprovei- } \\
\text { tamento } \\
\text { do } \mathrm{CO}_{2}\end{array}$} & 2- Uso intensivo na produção & 2.3 & 4.5 & - & 11,1 & - & 7,7 & . & . & . & . & - & - \\
\hline & 3 - Uso parcial na produção & - & - & - & - & . &. & - & - & . & 7,1 & - & - \\
\hline & 4-Em fase de pesquisas & . & - & $\therefore$ & - & - & - & - & . & 7,1 & 7,1 & . & . \\
\hline & 5-Descartado & 72,7 & 68,2 & 55,6 & 55,6 & 84,6 & 69,2 & 75,0 & 75,0 & 57,1 & 42,9 & 33,3 & 33,3 \\
\hline & Nenhuma resposta & 25.0 & 27,3 & 44,4 & 33,3 & 15,4 & 23,1 & 25,0 & 25,0 & 35,7 & 42,9 & 66,7 & 66,7 \\
\hline \multirow{9}{*}{$\begin{array}{l}\text { Aprovei- } \\
\text { tamento } \\
\text { das } \\
\text { Leve- } \\
\text { duras }\end{array}$} & 1 - Venda & 18,2 & 22,7 & . & - & - & . & - & . & 21,4 & 28,6 & - & . \\
\hline & 2. Uso intensivo na produção & 13,6 & 11,4 & 22,2 & 33,3 & 7,7 & 7,7 & 75,0 & 75,0 & 14,3 & 28,6 & 11,1 & 22,2 \\
\hline & 3 - Uso parcial na produção & 2,3 & 4,5 & - & $\therefore$ & $\dot{.}$ & 7,7 & 25,0 & 25,0 & 7,1 & 7,1 & 11,1 & 22,2 \\
\hline & 4-Em fase de pesquisas & 4.5 & 2,3 & & . & 23,1 & 15.4 & & & 7,1 & - & 11,1 & \\
\hline & 5-Descartado & 38,6 & 31,8 & 22,2 & 33,3 & 53,8 & 53,8 & - & & 14,3 & 21,4 & 22,2 & 11,1 \\
\hline & Combinação 1 e 2 (v-uip) & - & 2.3 & 11,1 & & &. & $=$ & & & & & \\
\hline & Combinação 1 e 3 (v-upp) & 2,3 & - & - & . & - & - & - & & & & & \\
\hline & Combinação 3 e 4 (upp-pes) & - & 4,5 & - & - & - & . & - & & & - & , & \\
\hline & Nenhuma resposta & 20,5 & 20.5 & 44,4 & 33,3 & 15.4 & 15,4 & - & - & 35,7 & 14,3 & 44,4 & 44,4 \\
\hline
\end{tabular}


continuação da Tabela anterior...

Tabela 33 - Aproveitamento de subprodutos - safras 1985/86 e 1995/96 - (valores em $\%)$.

\begin{tabular}{|c|c|c|c|c|c|c|c|c|c|c|c|c|c|}
\hline \multirow{2}{*}{\multicolumn{2}{|c|}{ Itens e especificações }} & \multirow{2}{*}{\multicolumn{2}{|c|}{ SP }} & \multirow{2}{*}{\multicolumn{2}{|c|}{$\mathrm{MG}$}} & \multirow{2}{*}{\multicolumn{2}{|c|}{ PR }} & \multirow{2}{*}{\multicolumn{2}{|c|}{$\mathrm{RJ}$}} & \multirow{2}{*}{\multicolumn{2}{|c|}{$\mathrm{PE}$}} & \multirow{2}{*}{\multicolumn{2}{|c|}{$\mathrm{AL}$}} \\
\hline & & & & & & & & & & & & & \\
\hline \multirow{8}{*}{$\begin{array}{l}\text { Aprovei- } \\
\text { tamento } \\
\text { da Torta } \\
\text { de Filtro }\end{array}$} & 1. Venda & 2,3 & 2,3 & & - & 7.7 & 7,7 & - & . & 7,1 & 7,1 & - & $\therefore$ \\
\hline & 2 - Uso intensivo na producaao & 54,5 & 72,7 & 77.8 & 66,7 & 23,1 & 76,9 & 75,0 & 75,0 & 50,0 & 64,3 & 33,3 & 44,4 \\
\hline & 3-Uso parcial na produção & 11,4 & 6,8 & - & - & 30,8 & - & - & - & . & - & 11,1 & - \\
\hline & 4-Em fase de pesquisas & . & - & + & - & 7,7 & . & . & - & 7,1 & - & . & - \\
\hline & 5-Descartado & 11,4 & 6,8 & & . & 23,1 & 15,4 & 25,0 & 25,0 & . & - & . & - \\
\hline & Combinação 1 e 2 (v-uip) & - & . & - & . & . & - & - & . & 7,1 & 7,1 & - & . \\
\hline & Combinação l e 3 (v-upp) & - & - & - & . & . & - & . & . & 7,1 & 7,1 & - & - \\
\hline & Nenhuma resposta & 20,5 & 11,4 & 22.2 & 33,3 & 7,7 & $=$ & - & $=$ & 21,4 & 14,3 & 55,6 & 55,6 \\
\hline \multirow{4}{*}{$\begin{array}{l}\text { Outros } \\
\text { subpro } \\
\text { dutos }\end{array}$} & 2 - Uso intensivo na produção & - & 2.3 & . & . & - & . & 二 & . & - & - & - & - \\
\hline & 4- Em fase de pesquisas & 2,3 & & 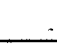 & & - & & - & & $=$ & - & - & - \\
\hline & Combinação 1 e 2 (v-uip) & 2,3 & 6,8 & - & . & - & - & . & & - & - & - & . \\
\hline & Não assinalou outro subproduto & 95.5 & 90,9 & 100 & 100 & 100 & 100 & 100 & 100 & 100 & 100 & 100 & 100 \\
\hline
\end{tabular}

Fonte: dados da pesquisa.

Como principal implicação sobre os três blocos de questionamentos analisados (políticas setoriais, P\&D e mudança técnica e da produção) cabe destacar que, além de uma diferença entre estados, houve também uma diferença entre as firmas pesquisadas dentro de cada estado mostrando que a evolução diferenciada da agroindústria canavieira também se deu em termos de capacitação tecnológica das firmas dentro dos estados.

Em termos de macrorregiões, ficou caracterizado que, não só no Norte-Nordeste, mas também no Centro-Sul, coexistem produtores considerados modernos com os atrasados. Outrossim, pode-se constatar um relativo avanço tecnológico para várias firmas cuja concentração técnica e econômica (em torno das agroindústrias canavieiras) é menor vis-à-vis São Paulo. Isto demonstra a assimilação do paradigma tecnológico como modelo de sobrevivência na agroindústria canavieira, sobretudo para períodos subseqüentes à desregulamentação setorial e diante da redução do número de unidades produtivas.

Para Nelson \& Winter (1982), o ambiente concorrencial tende a produzir vencedores e perdedores, onde algumas firmas certamente tirarão maior proveito das oportunidades técnicas do que outras. Nesta perspectiva evolucionista, importa estar atento à apuração dos custos e ao desenvolvimento de inovações tecnológicas, e, quem fez isto na agroindústria canavieira, pôde diferenciar-se dos demais. 
Através da análise das estratégias das firmas confirmou-se, também, a validade da hipótese em estudo, que diz respeito ao fato dos produtores ligados à agroindústria canavieira brasileira estarem inseridos, num primeiro momento, em um paradigma subvencionista; posteriormente, alguns desses produtores passaram a adotar o paradigma tecnológico como forma de definir o que é relevante para uma situação mais concorrencial. Daí uma das razões para a continuidade da ocorrência da evolução diferenciada verificada nessa agroindústria. 


\section{CONSIDERAÇÕES FINAIS}

O objetivo geral deste trabalho foi determinar e analisar os principais condicionantes da evolução diferenciada, entre estados $e$ entre firmas, ocorrida na agroindústria canavieira do Brasil de 1975 a 1995. Como objetivos especificos procurou-se obter algumas medidas do grau de modernização da agroindústria canavieira nos estados brasileiros, mediante utilização da técnica de análise fatorial; e, realizar uma análise das estratégias tecnológicas adotadas pelas firmas dessa agroindústria.

A única hipótese a ser testada neste estudo referiu-se ao fato dos produtores ligados à agroindústria canavieira brasileira estarem inseridos, num primeiro momento, em um paradigma subvencionista; posteriormente, alguns desses produtores passaram a adotar o paradigma tecnológico como forma de definir o que é relevante para uma situação mais concorrencial. Daí uma das razões para a ocorrência da evolução diferenciada verificada na agroindústria canavieira do Brasil.

Nestas considerações finais procura-se sumariar as principais implicações a que este estudo conduziu, de acordo com a ordenação dos capítulos.

Neste sentido, primeiramente efetuou-se uma breve análise da evolução da agroindústria canavieira brasileira de sua origem até 1974, e da organização dessa agroindústria, geração de tecnologia e principais produtos e subprodutos gerados. Isto porque uma visão histórica, auxiliada pela exposição de um panorama estrutural do que de fato existe no eixo agroindústria-mercado da economia canavieira, são contextos extremamente válidos para facilitarem o entendimento de certos aspectos da atual conjuntura da agroindústria canavieira.

De fato, historicamente, a agroindústria canavieira do Brasil fôra objeto de intervencionismo governamental, variando apenas de grau conforme as circunstâncias e 
interesses de cada época. Contudo, foi efetivamente a partir da criação do IAA, na década de 30, que o produtor da agroindústria canavieira passou a estar sujeito a uma série de arranjos institucionais que ligavam os interesses organizados do setor - sobretudo os do Nordeste - com as estruturas de decisão do Estado. Esse arranjo institucional, por um lado, proporcionava ao produtor, seja de que região fosse, um certo paradigma subvencionista como modelo de sobrevivência. Quer dizer, com mecanismos de regulação da atividade produtiva que iam desde o estabelecimento de quotas de produção (significando reserva de mercado), fixação de preços para a cana-de-açúcar, açúcar e álcool (significando uma certa garantia de margens mínimas de lucro), até a concessão de subsídios (significando um estímulo direto à atividade), o produtor da agroindústria canavieira não precisava, necessariamente, preocupar-se com alternativas tecnológicas que pudessem reduzir custos e proporcionar maior competitividade setorial, posto que sua permanência no setor estaria garantida minimamente pelos expedientes acima citados. Com tal panorama é incontroverso que muitos dos produtores da agroindústria canavieira se habituaram com este modelo de sobrevivência.

Destarte, estando a remuneração garantida, o uso de práticas rotineiras pôde ser continuamente reproduzida e os processos de busca e seleção passaram a ser condicionados por este paradigma subvencionista. Neste tocante, o Estado contribuiu para interferir, dessa vez com maior intensidade, no padrão de busca das empresas da agroindústria canavieira, exercendo influência sobre todos os elementos do mercado interno, sobre as exportações e, posteriormente, sobre as pesquisas agronômicas (via PLANALSUCAR) voltadas para o setor, ampliando enormemente a sua área de atuação.

Deve-se frisar que, mesmo antes de 1975, a agroindústria canavieira no Brasil já apresentava diferenciação entre seus estados produtores, com nítida hegemonia paulista. Não obstante, entre 1975 e 1995, fatores como a fragmentação do setor açucareiro mundial e o PROÁLCOOL irão proporcionar à agroindústria canavieira do País uma dinâmica diferente.

Sobre a agroindústria canavieira no subperíodo 1975-1979, dois pontos merecem ser acentuados. Primeiro, a crise do petróleo teve uma correlação positiva com a criação do PROÁlCOOL, não sendo, contudo, seu único determinante. A crise do petróleo gerou um "gargalo" no processo produtivo. O "gargalo" propicia um ambiente favorável ao surgimento de várias opções; neste caso, foram o uso do álcool, do carvão e do óleo 
vegetal. Contudo, a crise da agroindústria canavieira acabou favorecendo a "orquestração" de interesses que levou o País a optar pelo PROÁLCOOL. Nessa linha de raciocínio, a crise do petróleo levou ao surgimento de várias inovações, e a "orquestração" de interesses definiu qual proposta foi vitoriosa. Com efeito, a "orquestração" de interesses para viabilizar o PROÁLCOOL englobou os empresários das usinas e destilarias, o Estado, o setor de máquinas e equipamentos e a indústria automobilística. Para os usineiros tratava-se de diversificar a produção, de criar um novo mercado diante das freqüentes crises da economia açucareira, e diante também de um parque produtivo que precisava avançar tecnologicamente e que estava com tendência à sobrecapacidade. Para o Estado, os interesses nesse Programa resumiam-se nos seguintes objetivos: economia de divisas; diminuição das desigualdades regionais de renda; crescimento da renda interna; geração de empregos; e expansão da produção de bens de capital. Para o setor de máquinas e equipamentos (indústria de bens de capital), o advento do PROÁLCOOL permitia vislumbrar um quadro de continuidade do crescimento que havia sido iniciado ao final da década de 60 e que atingiu o seu auge no período do "milagre" econômico do País. Especificamente para a indústria automobilística, a crise do petróleo obstaculizava, de certa forma, a continuidade da política de transporte baseada em rodovias; e o carro movido a álcool despontava como uma alternativa para a continuidade dessa política de transporte.

Verifica-se, nesta "orquestração" de interesses, uma semelhança com a endogenia do processo de inovação enfatizado por Schumpeter, conquanto houve a presença de agentes no PROÁLCOOL que visaram o lucro com a abertura desse novo mercado para o álcool. Outra constatação é a de que as mudanças técnica e institucional decorrentes da implementação do PROÁLCOOL não tiveram os seus resultados e esforços inovativos conhecidos ex-ante, questão esta preconizada pelos neoschumpeterianos.

Quanto ao segundo ponto que caracterizou a subperíodo 1975-1979, o que se confirmou na agroindústria canavieira com o início do PROÁLCOOL foi o fato do produtor estar novamente sujeito a uma série de arranjos institucionais patrocinados pelo Estado, o que lhe garantia um paradigma subvencionista como modelo de sobrevivência. Com isso, muitos dos produtores aí inseridos passaram a conviver com expedientes como reserva de mercado, concessão de subsídios, entre outros, que geravam favoráveis margens de lucro. Se por um lado tal contexto foi bom para propiciar um maior desenvolvimento setorial, posto o arrefecimento forçado da concorrência, por outro lado 
contribuiu para a relativa falta de importância da tecnologia e do progresso técnico no interior desse setor.

Cinco fatos, imbricados entre si, descrevem o subperíodo 1980-1985, quais sejam:

- o aprofundamento do "gargalo" provocado pela segunda crise do petróleo, propiciou um ambiente favorável para o lançamento de um novo produto (o álcool hidratado), enquanto a "orquestração" de interesses procurou oportunamente corroborar a alternativa álcool combustível como a opção energética mais adequada para a substituição de derivados do petróleo, sobrepujando programas como o de óleos vegetais e de florestas energéticas;

- a "orquestração" de interesses foi mais intensa vis-à-vis a primeira fase, na qual sobressaíram as contribuições do Estado no sentido de reafirmar o padrão de busca das empresas da agroindústria canavieira, direcionando-o para a produção de álcool hidratado, e estimulando também o consumo do carro movido exclusivamente a álcool e o conseqüente consumo deste combustível;

- diante desse novo ímpeto no PROÁlCOOL, impulsionado que foi por um elenco de políticas de crédito, subsídio e preços (que tinham por trás vastos recursos financeiros, na maioria públicos), verificou-se, por um lado, o fortalecimento da posição hegemônica de alguns empresários considerados inovadores na agroindústria canavieira e, por outro lado, houve uma maior adesão de imitadores ao PROÁLCOOL, seja de empresários da própria agroindústria canavieira que ainda estavam receosos quanto ao futuro desse Programa, seja de empresários sem nenhuma tradição nesta atividade;

- a recente alteração geográfica da produção alcooleira nacional, a partir do crescimento da produção de álcool hidratado, evidenciou aumentos absolutos das produções em vários estados da União, não necessariamente seguidos de melhorias da participação percentual no total nacional. Foram estes os casos de áreas tradicionais na agroindústria canavieira, como Pernambuco e Rio de Janeiro. Ao contrário, São Paulo e Alagoas, dentre os mais tradicionais, e Mato Grosso do Sul, Mato Grosso e Goiás, dentre os novatos no setor, confirmaram estes dois aspectos, melhoria absoluta e relativa da produção alcooleira. Neste tocante, vale anotar a gradual perda de importância relativa de alguns empresários ligados aos estados que pioneiramente realizaram novas 
combinações no PROÁLCOOL, como do Rio de Janeiro, concomitante à elevação de importância dos imitadores;

- nessa segunda fase do PROÁLCOOL também ocorreu um novo período de desenvolvimento tecnológico na agroindústria canavieira, basicamente a partir de 198182 e que se prolongou até 1985, caracterizado pela busca de maior eficiência na conversão da sacarose para o produto final e nas reduções de custo de produção. Seguindo a própria heterogeneidade da produção canavieira do País, este desenvolvimento tecnológico também foi diferente para cada região e estado. A propósito, de acordo com Schumpeter, as inovações tendem a concentrar-se em algumas áreas da economia, sendo seu processo de difusão eminentemente desigual.

O subperíodo $\underline{1986 / 1995}$ do PROÁLCOOL apresentou, inicialmente, um panorama de desaceleração e depois de crise. Houve uma substancial redução da participação dos investimentos públicos no Programa e desequilíbrio entre a oferta e a demanda de álcool combustível, o que acabou levando à redução do interesse em produzir (na ótica da indústria automobilística) e a comprar um veículo a álcool (na ótica do consumidor).

Mas, por que razão teria o PROÁLCOOL entrado numa fase tão crítica, se sua "orquestração" de interesses, outrora bem sucedida, aparentava-se razoavelmente consolidada? Assim como a indagação, esta resposta passa pela relação entre "gargalo" tecnológico e "orquestração" de interesses. Faz-se necessário realçar que o "gargalo", oriundo da crise do petróleo, e que foi vital para a criação e posterior expansão do PROÁLCOOL, desapareceu. Assim sendo, desapareceu a justificativa diante da população brasileira para manter o corporatismo em torno desse Programa. Outrossim, da mesma forma que na primeira e segunda fase, onde o PROÁLCOOL obteve êxito com uma bem "orquestrada" junção de interesses, o seu malogro relativo deveu-se também a uma rápida desagregação desses interesses: seja no âmbito do Estado, agora revestido de uma tendência neoliberal e afetado por uma grave crise fiscal e financeira - que ainda mantém alguns privilégios da agroindústria canavieira, embora dê nítidos sinais de um gradual afastamento deste setor -; seja na deserção da indústria automobilística e/ou na falta de interesse do consumidor pelo carro a álcool, motivados pela diminuição das vantagens outrora concedidas para este tipo de veículo e diante das incertezas reinantes sobre o futuro do PROÁLCOOL; e, seja na própria agroindústria canavieira, capaz de 
redirecionar boa parte da produção canavieira para o mercado açucareiro ao menor sinal de elevação dos preços internacionais.

A crise do PROÁLCOOL (relacionada mormente à instabilidade da produção alcooleira e à queda nas vendas de veículos movidos a álcool) contribuiu para avultar a diferenciação em termos produtivos existente na agroindústria canavieira do País, posto que algumas empresas menos preparadas em termos de capacitação tecnológica encerraram suas atividades e/ou foram incorporadas pelas mais dinâmicas do setor. Há que ressaltar que a manutenção de usinas e destilarias ineficientes ainda se deve à regulação que o Estado mantém sobre o setor. "Um regime de maior liberdade de atuação deverá aumentar a participação no mercado das empresas mais eficientes que a média e com isso tornar o setor mais rentável" (Fernandes \& Coelho, 1996, p.154).

Os resultados derivados da análise fatorial proposta sugerem a modernização como estreitamente ligada ao produto álcool. Neste contexto, o PROÁLCOOL contribuiu não só para destacar perfomances como a de São Paulo no cenário nacional, como para melhorar o perfil geral da agroindústria canavieira do Brasil. Novas regiões canavieiras, como Mato Grosso do Sul (que concentra-se basicamente na produção alcooleira) e Paraná, alcançaram um relativo destaque neste setor. Entretanto, é preciso frisar que o impacto do PROÁLCOOL sobre a modernização da agroindústria canavieira não foi homogêneo. Vale lembrar, conforme Schumpeter, que o processo de difusão de uma inovação não é homogêneo, ocorrendo, em termos da agroindústria canavieira, e sob a instrumentalização da análise fatorial, uma evolução diferenciada entre os estados.

O estudo das medidas do grau de modernização da agroindústria canavieira no Brasil, mediante técnica de análise fatorial (método dos componentes principais), restringiu-se, pela dificuldade de obtenção de dados mais recentes, aos anos de 1975, 1980 e 1985. Por essa razão, fez-se premente uma análise mais atualizada do comportamento dos estados mais representativos da agroindústria canavieira para o período compreendido pelas safras 1985/1986 e 1995/1996, ressaltando, dessa vez, as estratégias tecnológicas das firmas.

No estudo das estratégias tecnológicas adotadas pelas firmas - enfocando sobretudo o período pós-extinção do IAA e as tendências atuais - ficou caracterizado que, não só no Norte-Nordeste, mas também no Centro-Sul, coexistem produtores 
considerados modernos com os atrasados. Outrossim, constatou-se um relativo avanço tecnológico para várias firmas de estados cuja concentração técnica e econômica (em torno de suas agroindústrias canavieiras) é menor vis-à-vis São Paulo. Isto demonstra, por sua vez, a assimilação do paradigma tecnológico como modelo de sobrevivência na agroindústria canavieira, sobretudo para períodos subseqüentes à desregulamentação setorial e diante da diminuição cada vez maior do número de unidades produtivas (não foi, portanto, um despropósito a maioria das firmas serem favoráveis à extinção de um órgão considerado regulador da economia canavieira - IAA -, e desfavoráveis à extinção de um órgão de pesquisa - PLANALSUCAR).

A P\&D se destacou, com maior veemência, em São Paulo, Paraná e Alagoas, sendo os principais fatores que barram a adoção de novas tecnologias: a falta de um mercado consolidado a ponto de incentivar o surgimento de novas tecnologias; a regulamentação do Estado que não favorece a inovação; e, a falta de recursos para tal finalidade. Sobre o uso de tecnologias agrícolas e mecânicas ficou evidente uma maior preocupação em reduzir custos, com intensificação do uso das tecnologias disponíveis, fato este corroborado com o maior aproveitamento dos subprodutos derivados da cana.

No panorama atual da agroindústria canavieira importa estar atento à apuração dos custos, ao desenvolvimento de novas tecnologias e aproveitamento de subprodutos, pois, quem fez isto pôde se diferenciar dos demais. Confirma-se, também em termos de firmas, a aceitabilidade da única hipótese testada neste estudo, que diz respeito ao fato dos produtores ligados à agroindústria canavieira brasileira estarem inseridos, num primeiro momento, em um paradigma subvencionista; posteriormente, alguns desses produtores passaram a adotar o paradigma tecnológico como forma de definir o que é relevante para uma situação mais concorrencial. Daí uma das razões para a continuidade da ocorrência da evolução diferenciada verificada na agroindústria canavieira do Brasil.

Ao procurar analisar a evolução diferenciada ocorrida na agroindústria canavieira do País, sob a ótica do desenvolvimento tecnológico, e com o instrumental analítico neoschumpeteriano e neocorporatista, esperou-se contribuir para a busca de um maior conhecimento sobre o setor em tela, em específico analisando as transformações ocorridas na década de 90. Com o advento da liberação dos preços e diante das novas condições de relação Estado e produtor, foi visto que as empresas não precisam mais de um órgão regulador como o IAA, e que as políticas de preços são, em sua maioria, 
inadequadas. Entrementes, um órgão de pesquisa - direcionado para a agroindústria canavieira - continua sendo um dos reclames do setor. Como possível política pública derivada deste trabalho, têm-se a necessidade do fortalecimento da pesquisa voltada para a agroindústria canavieira. Cabe lembrar que um ambiente favorável à pesquisa pode propiciar uma série de invenções, e as invenções aplicadas aos processos produtivos tornam-se inovações, que podem dar início a novos ciclos (Schumpeter, 1982).

Associando as três fases do PROÁLCOOL com as fases do ciclo econômico de Schumpeter, pode-se observar relações análogas entre ambas. A rigor, os ciclos na economia, segundo Schumpeter, possuem quatro fases: recuperação, prosperidade, recessão e depressão. A fase de expansão "moderada" do PROÁLCOOL (1975-1979) apresentou sinais de recuperação da economia canavieira; a expansão "acelerada" (19801985) foi o momento de auge nesse setor; enquanto a fase de "desaceleração e crise" (1986-1995) carrega sinais de retração econômica. Neste contexto, um período de reajustamento às crises irá fazer com que a produção seja parcialmente reorganizada, com redução dos custos de produção e ocorrência de falências de empresas que não obtiveram sucesso no ajustamento às variações das inovações. Em um dado momento, surgirão outras inovações que darão um novo direcionamento à agroindústria canavieira ou a outro setor da economia (Schumpeter, 1982).

Para o período pós-1995 observa-se, ad cautelam, que a agroindústria canavieira procura ajustar-se ao cenário de "desaceleração e crise", seja em forma de um novo produto (açúcar não calórico), no desenvolvimento de negociações do açúcar através das bolsas de mercadorias, futuros e opções, ou em forma de uma inovação institucional para revigorar o PROÁLCOOL ("imposto verde").

Assim, a resposta da agroindústria canavieira ao fenômeno da concorrência e substitutibilidade do açúcar que atingem esse mercado desde a década de 70 , parece estar vindo em forma de um novo tipo de açúcar. Este produto, originário da própria cana-deaçúcar, permanece com a capacidade de adoçar comidas e bebidas sem, contudo, gerar os efeitos iníquos que o açúcar comum (sacarose) pode provocar, ou seja, engordar indesejavelmente as pessoas, causar cáries e prejudicar pacientes de diabetes. Essa novidade para a agroindústria canavieira, a ser testada no mercado provavelmente a partir de 1998, desponta-se como uma forma encontrada por este setor produtivo para não se tornar vítima do processo inovativo que lançou no mercado os vários adoçantes 
substitutos e concorrentes do açúcar. Conforme Schumpeter ressaltou, o processo de mudanças tecnológicas revoluciona a estrutura econômica a partir de dentro, criando elementos novos (neste caso, o açúcar que não é metabolizado e, portanto, não produz calorias) e procurando destruir o antigo (os vários adoçantes substitutos e concorrentes do açúcar), como num processo de "destruição criadora" (desuso de produtos e processos decorrentes da inovação). Ressalta-se que o açúcar calórico continua tendo sua importância no contexto alimentar, sobretudo para as camadas de baixa renda.

Sobre as perspectivas para o mercado nacional do açúcar tradicional, surge a possibilidade de desenvolvimento de negociações feitas através das bolsas de mercadorias, futuros e opções. Neste caso, as vantagens da negociação em bolsas resumem-se não só no provável maior volume de transações no mercado, como na maior liquidez, na redução do risco da atividade - haja vista a minimização dos riscos derivados das transações de compra e venda e das flutuações dos preços - e estímulo aos mecanismos de trade finance para o setor.

Em termos do álcool combustivel, a reação contra a crise do PROÁLCOOL parece estar vindo em forma de uma nova "orquestração" de interesses em torno desse Programa, assentada maiormente na proposta de criação do "imposto verde", uma forma de estímulo ao PROÁlCOOL. Para o Estado esse estímulo ao PROÁlCOOL não se deve apenas ao fato do álcool ser menos poluente vis-à-vis a gasolina e o diesel, sendo a estabilidade da produção sucroalcooleira também uma preocupação do governo federal. Tanto para o setor de máquinas e equipamentos como para a indústria automobilística, os interesses no revigoramento do PROÁLCOOL devem-se às perspectivas de relativo crescimento das vendas. Já para a agroindústria canavieira, a volta do apoio ao PROÁLCOOL significa dar, no curto-prazo, vazão para o excedente estimado de 2,3 milhões de litros de álcool que será fabricado na safra 1997/98 e, no médio e longoprazos, diminuir a volatibilidade na renda do produtor de cana, açúcar e álcool.

Como futuras extensões do presente trabalho poder-se-ão, quando forem divulgados os novos Censos Agropecuários, estender a análise fatorial do capítulo 6 para períodos mais recentes. Além disso, novas pesquisas podem ser empreendidas para examinar a que grupos econômicos ou com que outras atividades se relacionam as firmas da agroindústria canavieira que adotaram o paradigma tecnológico e que puderam, assim, se distanciar das demais. 


\section{REFERÊNCIAS BIBLIOGRÁFICAS}

ABBOTT, G. C. Sugar. New York: Routledge, 1990. 360p.

ABREU, P. L. A visão do setor petróleo. In: FERNANDES, E. S. L.; COELHO, S. T. orgs. Perspectivas do álcool combustível no Brasil. São Paulo: USP - Instituto de Eletrotécnica e Energia, 1996. p. 23-27.

AÇÚCAR ideal. Problemas Brasileiros, n.287, p. 41-44, set./out. 1991.

AGRIANUAL 96 (Anuário estatístico da agricultura brasileira). São Paulo, 1996. 392p.

AGRIANUAL 97 (Anuário estatístico da agricultura brasileira). São Paulo, 1996. 435p.

ALAGOAS pede mais subsídio. Folha de São Paulo, São Paulo, 28 maio 1995. p.18.

ALBUQUERQUE, E. da M. e Notas sobre a contribuição de Kenneth Arrow para a fundamentação teórica dos "sistemas nacionais de inovação". Revista Brasileira de Economia, v.50, n.2, p. 227-242, abr./jun. 1996

ALBUQUERQUE, M.C.C. de; NICOL, R. Economia agrícola. São Paulo: McGrawHill, 1987. 335p.

ALLAIN, M. R. Financiamento externo e crescimento econômico no Brasil - 1965/1985. Belo Horizonte: BDMG, 1989. 38p.

ALMEIDA, E. S. de Considerações teóricas sobre o sistema schumpeteriano. Economia e Empresa, v.2, n.2, p. 4-12, abr./jun. 1995.

AMARAL, L. A canna de assucar. In: História da agricultura brasileira. São Paulo: Nacional, 1940. p. 61-184.

ANUÁRIO ESTATÍSTICO DO BRASIL - 1976 - 1977 - 1978, Rio de Janeiro. ANUÁRIO ESTATÍSTICO DO BRASIL - 1981 - 1982 - 1983 - 1984, Rio de Janeiro. ANUÁRIO ESTATÍSTICO DO BRASIL - 1985 - 1986 - 1987/88, Rio de Janeiro. ANUÁRIO ESTATÍSTICO DO BRASIL - 1989 - 1990 - 1991, Rio de Janeiro. ANUÁRIO ESTATÍSTICO DO BRASIL - 1992 - 1993 - 1994, Rio de Janeiro.

ARAÚJO, J. D. de Padrões tecnológicos e transformação no setor leiteiro: uma abordagem schumpeteriana. São Paulo, 1989. 125p. Tese (Doutorado) - 
Faculdade de Economia, Administração e Contabilidade, Universidade de São Paulo.

ASSOCIAÇÃO PROMOTORA DE ESTUDOS DA ECONOMIA $\underline{\text { A economia }}$ brasileira e suas perspectivas - APECÃO - XXXIV. Rio de Janeiro: APEC (E.34), 1995. 360p.

AZEVEDO, F. de Canaviais e engenhos na vida política do Brasil. 2.ed. São Paulo: Melhoramentos, 1958. 186p.

BACHA, C. J. C. Alguns aspectos dos modelos de análise dos impactos de mudança tecnológica no comportamento do setor agrícola. Revista de Economia e Sociologia Rural. v.30, n.1, p. 41-62, jan./abr. 1992.

BALSADI, O. V.; FARIA, C. A. C. de; NOVAES FILHO, R. Considerações sobre a dinâmica recente do complexo sucroalcooleiro no Estado de São Paulo. Informacões Econômicas, v.26, n.4, p. 21-29, abr. 1996.

BANCO CENTRAL DO BRASIL Relações econômico-financeiras com o exterior. Relatório 1985, v.22, p. 67-94, 1986.

BANCO CENTRAL DO BRASIL Setor externo da economia brasileira. Relatório de 1988 v. 25, p. $89-125,1989$.

BANCO CENTRAL DO BRASIL Setor externo da economia brasileira. Relatório de

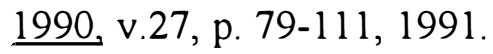

BANCO CENTRAL DO BRASIL Setor externo da economia brasileira. Relatório de 1991, v.28, p. 78-120, 1992.

BANCO CENTRAL DO BRASIL Relações econômico-financeiras com o exterior. Relatório de 1993, v.30, p. 83-142, 1993.

BANCO CENTRAL DO BRASIL Relações econômico-financeiras com o exterior. Relatório de 1994 v.31, p. 89-155, 1994.

BANCO CENTRAL DO BRASIL Suplemento estatístico. Brasília: BACEN, 1996. 469p.

BANCO DE DESENVOLVIMENTO DE MINAS GERAIS Minas Gerais e a economia acucareira. Belo Horizonte: BDMG, 1964. 48p.

BANCO DE DESENVOLVIMENTO DE MINAS GERAIS Relatório de pesquisa da agroindústria açucareira em Minas Gerais. Belo Horizonte: BDMG-DEP, 1969. $112 \mathrm{p}$. 
BANCO DE DESENVOLVIMENTO DE MINAS GERAIS Programa de recuperacão e expansão da indústria acucareira em Minas Gerais. Belo Horizonte: BDMG-DDI, 1973. 35p.

BANCO DE DESENVOLVIMENTO DE MINAS GERAIS Estudo setorial, modelo dinâmico de análise financeira, relatório de análise - indústria acucareira - Minas Gerais, 1981-84. Belo Horizonte: BDMG-CGPP, 1985. 40p.

BELIK, W. A tecnologia em um setor controlado: o caso da agroindústria canavieira em São Paulo. Cadernos de Difusão de Tecnologia v.2, n.1, p. 99-136, jan./abr. 1985.

BELIK, W. Agroindústria processadora e política econômica. Campinas, 1992. 219p. Tese (Doutorado) - Instituto de Economia, Universidade Estadual de Campinas.

BENAKOUCHE, R. A tecnologia enquanto forma de acumulação. Revista Economia e Desenvolvimento, n.2, p. 11-48, 1981.

BOYD JR., H. W.; WESTFALL, R. Pesquisa mercadológica. Rio de Janeiro: Fundação Getúlio Vargas, 1964. 315p.

BRASIL. COMISSÃO de Economia, Indústria e Comércio: Câmara dos Deputados. $\underline{\text { Relatório da subcomissão especial para exame da situação do setor sucroalcooleiro }}$ brasileiro. Brasília: Câmara dos Deputados, junho de 1991. 98p.

BRASIL. MINISTÉRIO da Agricultura. Perspectivas da demanda externa para o acúcar brasileiro no periodo 1979-85. Brasília: MINAGRI/SUPLAN, 1978. 38p.

BRAY, S. C. A formação do capital na agroindústria açucareira de São Paulo: revisão de paradigmas tradicionais. Rio Claro, 1989. 170p. Tese (Livre-Docência) Instituto de Geociências e Ciências Exatas, Universidade Estadual Paulista.

BRUGNARO, C. Estimativa do saldo do Governo na comercialização de álcool carburante. Piracicaba, 1992. 100p. Dissertação (M. S.) - Escola Superior de Agricultura "Luiz de Queiroz", Universidade de São Paulo.

BURNQUIST, H. L. Açúcar e álcool: safra 1996/97. Preços Agrícolas, n. 117, p. 6-9, out. 1996.

BURNQUIST, H. L.; BACCHI, M. R. P. Sazonalidade no mercado de açúcar. Preços agrícolas, v.10, n.115, p. 6-9, maio 1996.

CALAZANS, R. B. A lógica de um discurso: o empresário schumpeteriano. Ensaios FEE, v. 13, n.2, p. 640-667, 1992.

CALMON, P. O açúcar, sua história e influência na civilização brasileira. In: Anuário Acucareiro, 1935. p. 7-12. 
CAMARA, M. R. G. da Indústria farmacêutica: grupos estratégicos, tecnologia e regulamentação; a experiência brasileira em debate. São Paulo, 1993. 262p. Tese (Doutorado) - Faculdade de Economia, Administração e Contabilidade, Universidade de São Paulo.

CAMARGO, J. M. Tecnificação da cana-de-açúcar em São Paulo e sazonalidade da mão-de-obra. São Paulo, 1988. 218p. Dissertação (M. S.) - Faculdade de Economia, Administração e Contabilidade, Universidade de São Paulo.

CANTO, W. L. do Sistema ponderal de conversões e determinação de margens de comercialização. Estudos econômicos - alimentos processados, n.22, p.1-59, 1986.

CANUTO, O. Ciclos de vida do produto e vantagens de internacionalização de capacidades tecnológicas, sob uma abordagem evolucionista. In: ENCONTRO NACIONAL DE ECONOMIA, 19., Curitiba, 1991. Anais. Brasília: ANPEC, 1991. p. 313-334.

CANUTO, O. Competition and endogenous technological change: an evolutionary model. Revista Brasileira de Economia, v.49, n. 1, p. 21-33, jan./mar. 1995.

CARNEIRO, D. D. Crise e esperança: 1974-1980. In: ABREU, M. de P, org. A ordem do progresso: cem anos de política econômica republicana, 1889-1989. Rio de Janeiro: Campus, 1992. p. 295-322.

CARON, D. Novas tecnologias para a indústria sucroalcooleira. Preços Agrícolas, $n$. 121, p. 13-16, nov. 1996.

CARVALHO, F. C. de; YOSHII, R. J.; NOGUEIRA JUNIOR, S.; BRANDT, S. A. et al. Perda de mercado para o Brasil: a substituição de açúcar por frutose de milho nos Estados Unidos. In: CONGRESSO BRASILEIRO DE ECONOMIA E SOCIOLOGIA RURAL, 26., Fortaleza, 1988. Anais. Brasilia: SOBER, 1988. p. 843-852.

CARVALHO, F. C. de; YOSHII, R. J. Geração de energia a partir do bagaço da cana. In: CONGRESSO BRASILEIRO DE ECONOMIA E SOCIOLOGIA RURAL, 31., Ilhéus, 1993. Anais. Brasília: SOBER, 1993. p. 634-648.

CARVALHO, L. C.; CARON, D. Transferência de tecnologia na área canavieira. Boletim Técnico PLANALSUCAR v.4, n.1, p.1-16, 1982.

CARVALHO, L. C. C. de A visão do setor sucroalcooleiro. In: FERNANDES, E. S. L.; COELHO, S. T. orgs. Perspectivas do álcool combustivel no Brasil. São Paulo: USP - Instituto de Eletrotécnica e Energia, 1996. p. 28-48. 
CASTRO, A. B. de; SOUZA, F. E. P. A economia brasileira em marcha forcada. 2.ed. Rio de Janeiro: Paz e Terra, 1985. 217p.

CASTRO, R. AgroMarket, n.1, p. 18-23, abr./maio 1995.

CENSO AGROPECUÁRIO DO BRASIL - 1975 - 1980 - 1985. Rio de Janeiro. (para os estados de SP, MG, ES, RJ, PR, MS, MT, AL, PE, SE, PB, BA, RN, e CE)

CLARCK, H. Minas Gerais. Sinopse histórica do açúcar. In: Anuário Açucareiro, p. 7597, 1935.

COCHRANE, W. W. Development of american agriculture: a historical analysis. Minneapolis: University of Minnesota Press, 1979. 464p.

COMPANHIA ENERGÉTICA DE MINAS GERAIS Minas Gerais - cenários da economia mineira 1986/2005 - n. 5 - Acúcar. Belo Horizonte: CEMIG/INDI, 1987a. 33p.

COMPANHIA ENERGÉTICA DE MINAS GERAIS Minas Gerais - cenários da economia mineira 1986/2005 - n. 7 - Álcool. Belo Horizonte: CEMIG/INDI, 1987b. 48p.

COMPANHIA ENERGÉTICA DE MINAS GERAIS Uso de energia na indústria de açúcar e álcool em Minas Gerais. Belo Horizonte: CEMIG, 1990. 79p.

CONFEDERAÇÃO NACIONAL DA INDÚSTRIA O setor produtor de açúcar e álcool - sua importância no universo industrial brasileiro. In:__. Acúcar e álcool: problemas da agroindústria canavieira; o setor produtor de acúcar e álcool; notas sobre mercados externos. Rio de Janeiro: CNI/Edições I \& P, 1985a. p. 47-85.

CONFEDERAÇÃO NACIONAL DA INDÚSTRIA Açúcar e álcool - notas sobre mercados externos. In:__. Açúcar e álcool problemas da agroindústria canavieira; o setor produtor de acúcar e álcool; notas sobre mercados externos. Rio de Janeiro: CNI/Edições I \& P, 1985b. p. 87-143.

CONN, E. E.; STUMPF, P. K. Manual de bioquímica. São Paulo: Edgard Blücher, 1973. 420p.

COOPERATIVA DOS PRODUTORES DA CANA, AÇÚCAR E ÁLCOOL DO ESTADO DE SÃO PAULO LTDA Fundamentos dos processos de fabricacão de açúcar e álcool. São Paulo: Centro Tecnológico da COPERSUCAR, 1988. 12p. (Série Industrial, n.20)

COOPERATIVA DOS PRODUTORES DA CANA, AÇÚCAR E ÁLCOOL DO ESTADO DE SÃO PAULO LTDA Cana, acúcar e álcool. São Paulo: COPERSUCAR, 1989a. 55p. 
COOPERATIVA DOS PRODUTORES DA CANA, AÇÚCAR E ÁLCOOL DO ESTADO DE SÃO PAULO LTDA Proálcool: fundamentos e perspectivas. São Paulo: COPERSUCAR, 1989b. $121 \mathrm{p}$.

COOPERATIVA DOS PRODUTORES DA CANA, AÇÚCAR E ÁLCOOL DO ESTADO DE SÃO PAULO LTDA Álcool, energia da biomassa: aspectos tecnológicos e econômicos da produção (Conferência proferida pelo Engenheiro João Guilherme Sabino Ometto - Presidente da Copersucar). São Carlos: Escola de Engenharia de São Carlos - USP;COPERSUCAR, 1993. 37p.

COSTA FILHO, M. A cana-de-acúcar em Minas Gerais. Rio de Janeiro: IAA, 1963. 432p.

CRISE em Alagoas arrasta o setor privado. Folha de São Paulo, São Paulo, 8 jun. 1997. p. $1-8$.

CRUZ, H. N. Observações sobre a mudança tecnológica em Schumpeter. Estudos Econômicos, v.18, n.3, p. 433-448, set./dez. 1988.

DÉ CARLI, G. O açúcar na formação econômica do Brasil. In: Anuário Açucareiro. p. 7-72, 1936.

DÉ CARLI, G. Aspectos da economia acucareira. Rio de Janeiro: Pongetti, 1942. $304 p$.

DÉ CARLI, G. Gênese e evolução da indústria açucareira de São Paulo. Rio de Janeiro: Pongetti, 1943. 228p.

DOSI, G. Technical change and industrial transformation. New York: St. Martin's Press, 1984. 338p.

EID, F. Progresso técnico na agroindústria sucroalcooleira. Informacões Econômicas, v.26, n. 5, p. 29-36, maio 1996.

EISENBERG, P. L. Modernização sem mudanca: a indústria acucareira em Pernambuco, 1840-1910. Campinas: Paz e Terra;UNICAMP, 1977. 294p.

EKERMAN, R; ZERKOWSKI, R. M. A análise teórica schumpeteriana do ciclo econômico. Revista Brasileira de Economia v.38, n.3, p. 205-228, jul./set. 1984.

FAO TRADE YEARBOOK - 1992 -. Rome, v.46, 1992.

FARIAS, E. Maiores investimentos em Pernambuco. Agroanalysis, v.15, n.3, p. 15-16, mar. 1995.

FAZENDA quer 'rolar' só créditos bons. Folha de São Paulo, São Paulo, 25 mar. 1996. p.1-8. 
FERGUSON, C. E. Microeconomia. Rio de Janeiro: Forense-Universitária, 1984. $624 \mathrm{p}$.

FERNANDES, E. S. L.; COELHO, S. T., orgs. Perspectivas do álcool combustível no Brasil. São Paulo: USP - Instituto de Eletrotécnica e Energia, 1996. 166p.

FERREIRA, A. A. A transferência de tecnologia e o processo de adoção de inovações: estudo do setor agrícola da cana-de-açúcar no Estado de São Paulo. São Paulo, 1981. 235p. Tese (Doutorado) - Faculdade de Economia, Administração e Contabilidade, Universidade de São Paulo.

FIGUEIREDO, N. M. S. de Modernização, distribuição da renda e pobreza na agricultura brasileira, 1975, 1980 e 1985. Piracicaba, 1996. 248p. Tese (Doutorado) - Escola Superior de Agricultura "Luiz de Queiroz", Universidade de São Paulo.

FISCHER, A. L. Impactos sociais do Proálcool: um estudo sobre as relações, o processo e as condições de trabalho na agroindústria canavieira paulista. São Paulo, 1992. 238p. Dissertação (M. S.) - Pontifícia Universidade Católica/SP.

FRANCO JÚNIOR, H.; CHACON, P. P. História econômica geral. São Paulo: Atlas, 1986. 283p.

FREEMAN, C. Innovation and the strategy of the firm. In: FREEMAN, C. The economics of industrial innovation. Harmondsworth: Penguin Books, 1974. p.225282.

FREEMAN, C. New technology and catching-up. SPRU-Sussex, 1989 (mimeografado).

FREEMAN, C.; CLARK, J.; SOETE, L. Unemployment and technical innovation. London: Frances Pinter, 1982. 214p.

FUNDAÇÃO GETÚLIO VARGAS Subsídios para fixação dos preços da cana-deacúcar e do acúcar. Safra 1984-1985. Rio de Janeiro: FGV;IAA, 1984. 163p.

FUNDAÇÃO GETÚLIO VARGAS (FGV) Subsídios para fixação dos preços da canade-acúcar, do açúcar e do álcool. Safra 1985-1986. Rio de Janeiro: FGV;IAA, 1985. $151 \mathrm{p}$.

FUNDAÇÃO GETÚLIO VARGAS (FGV) Subsídios para fixação dos preços da canade-acúcar, do acúcar e do álcool. Safra 1986-1987. Rio de Janeiro: FGV;IAA, 1986. 189 p. 
FUNDAÇÃO GETÚLIO VARGAS (FGV) Subsídios para fixacão dos preços da canade-açúcar, do acúcar e do álcool. Safra 1987-1988. Rio de Janeiro: FGV;IAA, 1987. 189p.

FUNDAÇÃO GETÚLIO VARGAS (FGV) Subsídios para fixacão dos preços da canade-açúcar, do acúcar e do álcool. Safra 1988-1989. Rio de Janeiro: FGV;IAA, 1988. 200p.

FUNDAÇÃO INSTITUTO BRASILEIRO DE GEOGRAFIA E ESTATÍSTICA Estatísticas históricas do Brasil: séries econômicas, demográficas e sociais de 1550 a 1988. 2.ed. Rio de Janeiro: FIBGE, 1990. 642p.

FURTADO, C. Formação econômica do Brasil. 12.ed. Rio de Janeiro: Nacional, 1974. 248p.

FURTADO, A., coord. Capacitação tecnológica, competitividade e política industrial: uma abordagem setorial e por empresas líderes. Texto para discussão. IPEA n.348, p. 1-133, 1994.

GALBRAITH, J. K. O pensamento econômico em perspectiva: uma história crítica. São Paulo: Pioneira;Editora da USP, 1989. 289p.

GARCIA, M. de F. O impacto do Proálcool na economia agrícola do Ceará. Porto Alegre, 1984. 169p. Dissertação (M. S.) - Faculdade de Ciências Econômicas, Universidade Federal do Rio Grande do Sul.

GARCIA, M. de F.; ADAMS, R. I. A produção de álcool - aspectos de competitividade no Ceará. In: CONGRESSO BRASILEIRO DE ECONOMIA E SOCIOLOGIA RURAL, 26., Fortaleza, 1988. Anais. Brasilia: SOBER, 1988. p. 735-759.

GIL, A. C. Pesquisa em economia. São Paulo: Atlas, 1991. 195p.

GNACCARINI, J. C. Estado, ideologia e ação empresarial na agroindústria açucareira do Estado de São Paulo. São Paulo, 1972. 250p. Tese (Doutorado) - Faculdade de Filosofia, Letras e Ciências Humanas, Universidade de São Paulo.

GNACCARINI, J. C. Latifúndio e proletariado (formação da empresa e relações de trabalho no Brasil rural). São Paulo: Polis, 1980. 185p.

GOLDIN, I.; REZENDE, G. C. A agricultura brasileira na década de 80: crescimento numa economia em crise. Rio de Janeiro: IPEA, 1993. 119p.

GOMES NETO, A. L. O Programa Nacional do Álcool e o Estado do Espírito Santo como pólo alcooleiro. São Paulo, 1979. 139p. Dissertação (M. S.) - Faculdade de Economia, Administração e Contabilidade, Universidade de São Paulo. 
GONTIJO, C. Avaliação econômica do Programa Nacional do Álcool. Belo Horizonte: FINEP/CEDEPLAR, 1985. 296p.

GOVERNO apressa criação do imposto verde. Folha de São Paulo, São Paulo, 22 ago. 1997. p.2-5.

GOVERNO estuda nova ajuda a usineiros. Folha de São Paulo, São Paulo, 3 nov. 1995. p.1-7.

GUERRA, N. A. M. O Pró-álcool e as transformações no espaço agrícola do Paraná. Economia em Revista, v.4, n.2, p. 81-95, 1995.

GUIA DOS PRODUTORES DE AÇÚCAR E ÁlCOOL - REGIÃO CENTRO-SUL SAFRA 1995/96. 11 ed. Franca: EPK, 304p.

GUIA DOS PRODUTORES DE AÇÚCAR E ÁLCOOL - REGIÃO NORTENORDESTE - SAFRA 1995/96. 5 ed. Franca: EPK, 135p.

HARMAN, H. H. Modern factor analysis. 3 ed. Chicago: University of Chicago Press, 1976.

HAYAMI, Y.; RUTTAN, V. Agricultural development an international perspective. Baltimore: John Hopkins University Press, 1971. 367p.

HICKS, J. The theory of wages. Londres: MacMillan, 1932. 247p.

HOFFMANN, R. A dinâmica da modernização da agricultura em 157 microrregiões homogêneas do Brasil. Revista de Economia e Sociologia Rural, v.30, n.4, p. 271 290, out./dez. 1992.

HOFFMANN, R. Componentes principais e análise fatorial Série Didática. DERS. ESALQ, n.90, p.1-37. 1994

JAMBEIRO, M. de B. Engenhos de rapadura: racionalidade do tradicional numa sociedade em desenvolvimento. São Paulo: Instituto de Estudos Brasileiros da USP, 1973. 193p.

JANK, M. S. A revolução tecnológica e o papel da CEE no mercado de açúcar. Revista Brasileira de Comércio Exterior, v.22, p. 30-34, mar./abr. 1989.

JOHNSON, R. A.; WICHERN, D. W. Applied multivariate statistical analysis. Englewood Cliffs: Prentice Hall, 1982.

KATZ, J. Importación de tecnologia, aprendizaje local y industrialización dependiente. Washington: OEA, 1972. 432p.

KEYNES, J. M. A teoria geral do emprego, do juro e da moeda; inflação e deflação. São Paulo: Abril Cultural, 1983. 333p. (Série "Os economistas") 
$\mathrm{KOCH}, \mathrm{J} . \mathrm{V}$. Industrial organization and prices. 2.ed. New Jersey: Prentice-Hall, 1980. $504 \mathrm{p}$.

KUHN, T. S. A estrutura das revoluções científicas. 3 ed. São Paulo: Perspectiva, 1995. 257p.

KUPFER, D. Padrões de concorrência e competitividade. In: ENCONTRO NACIONAL DE ECONOMIA, 20., Campos de Jordão, 1992. Anais. Brasília: ANPEC, 1992. p. 261-281.

KUPFER, D. Uma abordagem neo-schumpeteriana da competitividade industrial. Ensaios FEE, v.17, n. 1, p. 355-372. 1996

LABINI, P. S. Oligopólio e progresso técnico. São Paulo: Forense, 1980. 306p.

LAGO, L. A. C. do A. Retomada do crescimento e as distorções do "milagre": 19671973. In: ABREU, M. de P, org. A ordem do progresso: cem anos de política econômica republicana, 1889-1989. Rio de Janeiro: Campus, 1992. p. 233-294.

LALL, S. Technological capabilities. In.: SALOMON, J.; SAGASTI, F. R.; SACHSJEANTET, C. The uncertain quest: science, technology and development. Tokyo: United Nations University Press, 1994. p. 264-301.

LIBERAÇÃO de preços é uma opção estudada. Folha de São Paulo São Paulo, 25 fev. 1996. p.1-10.

LIMA, G. T. Development, technological change and innovation: Schumpeter and the neo-schmpeterians. Revista Brasileira de Economia v.50, n.2, p. 179-204, abr./jun. 1996.

LIMA, J. de Análise econômica da cultura de cana-de-açúcar do Estado de Alagoas safra 1973/74. Viçosa, 1976. 107p. Dissertação (M. S.) - Universidade Federal de Viçosa.

LMA, J. C. de S. A intervenção governamental no setor açucareiro: ênfase à problemática do subsídio de equalização. São Paulo, 1992. 118p. Tese (Doutorado) - Faculdade de Economia, Administração e Contabilidade, Universidade de São Paulo.

LIMA, J. P. R. O Estado e a agroindústria canavieira do Nordeste: a acumulação administrada. Revista Econômica do Nordeste v.19, n.4, p. 431-449, out./dez. 1988a.

LIMA, J. P. R. Estado e grupos não hegemônicos; o lobby sucroalcooleiro do Nordeste. In: ENCONTRO NACIONAL DE ECONOMIA, 16., Belo Horizonte, 1988. Anais. Brasília: ANPEC, 1988b. p. 579-598. 
LIMA, J. P. R.; MELO, L. C. P. de Cana-de-açúcar no Nordeste; ostracismo tecnológico, caminhos alternativos e rebatimentos regionais. In: ENCONTRO NACIONAL DE ECONOMIA, 17., Fortaleza, 1989. Anais. Brasília: ANPEC, 1989. p. 1287-1301.

LIMA, J. P. R.; SILVA, G. V. A economia canavieira de Pernambuco e a reestruturação necessária. Revista Econômica do Nordeste, v.26, n.2, p. 181-203, abr./jun. 1995.

LLANILLO, Rafael Fuentes. Caracterização da estrutura de produção agropecuária do Estado do Paraná. Piracicaba, 1984. 177p. Dissertação (M. S.) - Escola Superior de Agricultura "Luiz de Queiroz", Universidade de São Paulo.

LOPES, L. A. Análise da competição entre culturas alimentares exportáveis e a cana-deaçúcar no Paraná. São Paulo, 1985. 160p. Dissertação (M. S.) - Faculdade de Economia, Administração e Contabilidade, Universidade de São Paulo.

LOPES, L. A. Vinte anos de Proálcool: avaliações e perspectivas. Economia \& Empresa, v.3, n.2, p. 49-57, abr./jun. 1996.

LÓPEZ, V. Regimen azucarero de la Comunidad Economica Europea. In: SEMINÁRIO NACIONAL SOBRE COMERCIALIZACION INTERNACIONAL DEL AZUCAR, Piracicaba, 1992. Anais. Piracicaba, ESALQ/GEPLACEA, 1992. p.1-5.

LUNDVALL, B. A. Innovation as an interactive process: from user-producer interaction to the national system of innovation. In.: DOSI, G. et al., eds. Technical change and economic theory. London: Pinter Publishers; Nova York: Columbia University Press, 1988. p. 349-369

MACEDO, I. de C. A tecnologia para o setor sucroalcooleiro: situação atual e perspectivas. In: FERNANDES, E. S. L.; COELHO, S. T. orgs. Perspectivas do álcool combustivel no Brasil. São Paulo: USP - Instituto de Eletrotécnica e Energia, 1996. p. 57-64.

MAGALHÃES, J. P. de A.; KUPERMAN, N.; MACHADO, R. C. Proálcool: uma avaliação global. Rio de Janeiro: Astel, 1991. 197p.

MANOEL, A. Política agrícola, eficiência e concentração na agricultura brasileira: um estudo do setor canavieiro paulista. São Paulo, 1985. 222p. Tese (Doutorado) Faculdade de Economia, Administração e Contabilidade, Universidade de São Paulo. 
MEDEIROS, N. H. A competição schumpeteriana e a organização cooperativa: o caso da "COCAMAR". São Paulo, 1995. 235p. Tese (Doutorado) - Faculdade de Economia, Administração e Contabilidade, Universidade de São Paulo.

MELO, F. H. de; FONSECA, E. G. da Proálcool, energia e transportes. São Paulo: FIPE/PIONEIRA, 1981. 163p.

MELO, F. H. de; PELIN, E. R. As soluções energéticas e a economia brasileira. São Paulo: HUCITEC, 1984. 146p.

MENDES, C. Problemas da agroindústria canavieira. In:__ Açúcar e álcool: problemas da agroindústria canavieira; o setor produtor de acúcar e álcool; notas sobre mercados externos. Rio de Janeiro: CNI/Edições I \& P, 1985. p. 9-43.

MEYER, A. C. São Paulo. Sinopse histórica do açúcar. In: Anuário Açucareiro. Rio de Janeiro, 1935. p. 153-163.

MINISTÉRIO cria certificado para impedir fraudes de usineiros. O Estado de São Paulo, São Paulo, 2 ago. 1997. p.B-5.

MOREIRA, E. F. P. Expansão, concentração e concorrência na agroindústria canavieira em São Paulo: 1975 a 1987. Campinas, 1989. 119p. Dissertação (M. S.) Instituto de Economia, Universidade Estadual de Campinas.

MOREIRA, M. M. Progresso técnico e estrutura de mercado: o caso da indústria de telequipamentos. Rio de Janeiro: BNDES, 1989. $151 \mathrm{p}$.

MOTA, J. de S. A agro-indústria sucro-alcooleira no Estado de Minas Gerais. Usineiro, v.2, n.9, p. 42-49, jul./ago. 1987.

MOTTA, R. S. da Um estudo de custo-beneficio do PROÁlCOOL. Pesquisa e Planejamento Econômico, v.17, n. 1, p. 65-92, abr. 1987.

MOWERY, D.; ROSENBERG, $\mathrm{N}$. The influence of market demand upon innovation: a critical review of some recent empirical studies. In: ROSENBERG, N., org. Inside the black-box - technology and economics. Cambridge: Cambridge University Press, 1982. p. 193-241.

NASTARI, P. M. Tecnologia, custos e competitividade no Mercosul: o caso do açúcar e do álcool. In: RICARDO, S., org. Estudos Avançados. Colecão Documentos. Série: A integração regional e o Mercosul - 3. A agropecuária brasileira e o Mercosul. São Paulo: Instituto de Estudos Avançados, 1992. p. 125-152.

NEGRI, B. Indústria brasileira de equipamentos para o setor produtor de açúcar e álcool: um estudo de oligopólio. Revista de Economia Política, v.1, n.3, p.83-105, jul./set. 1981. 
NELSON, R. La economía sencilla de la investigación científica básica In: ROSENBERG, N., org. Economía del cambio tecnológico. México: Fondo de Cultura Económica, 1979. p. 136-150.

NELSON, R. R.; WINTER, S. G. In search of a useful theory of innovations. Research Policy v.6, n. 1, p. 36-76, jan. 1977.

NELSON, R. R.; WINTER, S. G. An evolutionary theory of economic change. Cambridge: Harvard University Press, 1982. 437p.

NEVES, D. P. Lavradores e pequenos produtores de cana: estudo das formas de subordinação dos pequenos produtores agrícolas ao capital. Rio de Janeiro: Zahar, 1981. 212p.

NOTHENBERG, M. Bactéria produz resina biodegradável de açúcar. Plástico Moderno, p. 28-33, set. 1995.

NOVO açúcar beneficia diabéticos e obesos. O Estado de São Paulo, São Paulo, 9 mar. 1997. p.A-30.

OLALDE, A. R. Desenvolvimento tecnológico e competitividade da indústria brasileira: a indústria sucro-alcooleira. Campinas: SCTDE/FECAMP/ UNICAMP-IE, 1993. 76p. (Relatório Final - Contrato)

ORSENIGO, L. The emergence of biotechnology - institutions and markets in industrial innovation. London: Pinter Publishers, 1989. 230p.

OSER, J.; BLANCHFIELD, W. C. História do pensamento econômico. São Paulo: Atlas, 1983. 455p.

PAIVA, R. M.; SCHATTAN, S.; FREITAS, C. F. T. Setor agrícola do Brasil comportamento econômico, problemas e possibilidades. São Paulo: Secretaria da Agricultura, 1973. 456p.

PARRO, J. E. A visão do setor automobilístico. In: FERNANDES, E. S. L.; COELHO, S. T. orgs. Perspectivas do álcool combustivel no Brasil. São Paulo: USP Instituto de Eletrotécnica e Energia, 1996. p. 19-22.

PELIN, E. R. Avaliação econômica do álcool hidratado carburante no curto e médio prazo. São Paulo, 1983. 36lp. Tese (Doutorado) - Faculdade de Economia, Administração e Contabilidade, Universidade de São Paulo.

PENROSE, E. Teoria del crescimento de la empresa. Madrid: Aguilar, 1962. 298p.

PETRONE, M. T. S. A lavoura canavieira em São Paulo. São Paulo: Difusão Européia do Livro, 1968. 24lp. 
PINA, H. A agro-indústria açucareira e sua legislação. Rio de Janeiro: APEC, 1972. $364 \mathrm{p}$.

PLOTT, C. R. An updated review of industrial organization: applications of experimental methods. In: SCHMALENSEE, R.; WILLIG, R. D. Handbook of industrial organization. Amsterdam: North-Holland, 1989. v.2, p. 1109-1176.

POSSAS, M. L. Estruturas de mercado em oligopólio. 2 ed. São Paulo: HUCITEC, 1987. $191 \mathrm{p}$.

POSSAS, M. L. Concorrência, inovação e complexos industriais: algumas questões conceituais. Cadernos de Ciência \& Tecnologia v.8, n.1/3, p. 78-97, jan./dez. 1991.

PRADO JÚNIOR, C. História econômica do Brasil. 26.ed. São Paulo: Brasiliense, 1981. 364p.

PREÇOS AGRÍCOLAS, Piracicaba, v. 10, n.112, fev. 1996.

PROÁLCOOL gera R $\$ 1,3$ bi de prejuízo por ano e mantém 1,3 milhão de empregos. Folha de São Paulo, São Paulo, 25 fev. 1996. p.1-10.

QUADROS, S. Ajuste necessário. Agroanalysis, v. 15, n.3, p. 21-22, mar. 1995

QUEDA, O. A intervenção do Estado e a agro-indústria açucareira paulista. Piracicaba, 1972. 173p. Tese (Doutorado) - Escola Superior de Agricultura "Luiz de Queiroz", Universidade de São Paulo.

RAMOS, P. Um estudo da evolução e da estrutura da agroindústria canavieira do Estado de São Paulo (1930-1982). São Paulo, 1983. 258p. Dissertação (M. S.) Escola de Administração e Economia, Fundação Getúlio Vargas/SP.

RAMOS, P. Agroindústria canavieira e propriedade fundiária no Brasil. São Paulo, 1991. 331 p. Tese (Doutorado) - Escola de Administração e Economia, Fundação Getúlio Vargas/SP.

RAMOS, P.; BELIK, W. Intervenção estatal e a agroindústria canavieira no Brasil. Revista de Economia e Sociologia Rural, v.27, n.2, p. 197-214, abr./jun. 1989.

RENAULT, C. M. A cana-de-açúcar e a agroindústria açucareira em Minas Gerais. Belo Horizonte: CEPA/MG, 1978. $131 \mathrm{p}$.

RENNÓ, J. M. Álcool e petróleo - aspectos da questão. Agroanalysis v. 15, n.3, p. 2324, mar. 1995

REYES, M. S. Z. Proálcool e emprego no Estado de São Paulo. São Paulo, 1989. 14lp. Dissertação (M. S.) - Faculdade de Economia, Administração e Contabilidade, Universidade de São Paulo. 
RICCI, R., coord. Mercado de trabalho do setor sucroalcooleiro no Brasil. Brasília: IPEA, 1994. 176p. (Estudos de Política Agrícola, n. 15).

RICO, M. Situacion actual y perspectivas del mercado mundial. In: SEMINÁRIO NACIONAL SOBRE COMERCIALIZACION INTERNACIONAL DEL AZUCAR, Piracicaba, 1992. Anais. Piracicaba: ESALQ/GEPLACEA, 1992a, p. 1-3.

RICO, M. El contrato azucarero. In: SEMINÁRIO NACIONAL SOBRE COMERCIALIZACION INTERNACIONAL DEL AZUCAR, Piracicaba, 1992. Anais. Piracicaba: ESALQ/GEPLACEA, 1992b, p. 1-11.

ROCHA JÚNIOR, W. F. da Suco de laranja concentrado congelado (SCLL) em concessionárias de refeições coletivas (um estudo exploratório). Piracicaba, 1994. 106p. Dissertação (M. S.) - Escola Superior de Agricultura "Luiz de Queiroz", Universidade de São Paulo.

RODRIGUES, I. P. da F. Estilo gerencial e lucratividade da cana-de-açúcar (um estudo sobre as variáveis sócio-econômicas no processo decisório do gerente rural ligado à cana-de-açúcar na região de Ponte Nova, MG). Belo Horizonte, 1979. 143p. Dissertação (M. S.) - Faculdade de Ciências Econômicas, Universidade Federal de Minas Gerais.

ROSENBERG, N. The direction of technological change. Inducement mechanisms and focusing devices. Economic Development and Cultural Change, v. 18, n.1, p. 1-24, october 1969.

ROSENBERG, N. Inside the black box: technology and economics. Cambridge: Cambridge University Press, 1982. 304p.

ROSENBERG, N.; FRISCHTAK, C. R. Inovação tecnológica e ciclos de Kondratiev. Pesquisa e Planejamento Econômico, v.13, n.3, p. 675-706, dez. 1983

SAES, M. S. M. A racionalidade econômica da regulamentação no mercado brasileiro de café. São Paulo, 1995. 166p. Tese (Doutorado) - Faculdade de Economia, Administração e Contabilidade, Universidade de São Paulo.

SALLES FILHO, S. L. M. Mudanças no padrão tecnológico da agricultura: uma perspectiva para o final do século. In: CONGRESSO BRASILEIRO DE ECONOMIA E SOCIOLOGIA RURAL, 31, Ilhéus, 1993. Anais. Brasília: SOBER, 1993. p. 86-100.

SALLES FILHO, S. L. M.; SILVEIRA, J. M. F. J. da A teoria da inovação induzida e os modelos de "demand pull": uma crítica com base no enfoque neo- 
schumpeteriano. In: CONGRESSO BRASILEIRO DE ECONOMIA E SOCIOLOGIA RURAL, 28., Florianópolis, 1990. Anais. Brasília: SOBER, 1990. p. 41-60.

SALLES FILHO, S. L. M.; SILVEIRA, J. M. F. J. da Relações agricultura/indústria, complexos agroindustriais e a dinâmica concorrencial. In: CONGRESSO BRASILEIRO DE ECONOMIA E SOCIOLOGIA RURAL, 29., Campinas, 1991. Anais. Brasilia: SOBER, 1991. p. 90-119.

SALLES FILHO, S. L. M.; SILVEIRA, J. M. F. J. da As fontes de inovação da agricultura e suas transformações recentes. In: ENCONTRO NACIONAL DE ECONOMIA, 21., Belo Horizonte, 1993. Anais. Brasília: ANPEC, 1993. p. 155174

SANTOS, I. F. B. dos Contrato FGV/MICT. Agroanalysis, v.16, n.11, p. 63-64, nov. 1996.

SAVIOTTI, P.; METCALFE, J. Present development and trends in evolutionary economics. In: SAVIOTTI, P.; METCALFE, J., orgs. Evolutionary theories of economic and technological change - present status and future prospects, Chur, Suíça: Harwood Academic Publishers, 1991. p. 1-30.

SCHMITTER, P. C. Neocorporatismo y Estado. REIS - Revista Espanhola de Sociologia, n. 31, p. 47-78, 1985.

SCHMOOKLER, J. Fuentes económicas de la actividad inventiva In: ROSENBERG, N. org. Economía del cambio tecnológico, México: Fondo de Cultura Económica, 1979. p. 107-125.

SCHUMPETER, J. A. Capitalismo, Socialismo e Democracia. Rio de Janeiro: Fundo de Cultura, 1961. 512p.

SCHUMPETER, J. A. Teoria do desenvolvimento econômico. São Paulo: Abril Cultural, 1982. 169p. (Série "Os economistas")

SHAPIRO, E. Análise macroeconômica. 2.ed. São Paulo: Atlas, 1981. 776p.

SHIKIDA, P. F. A. O açúcar brasileiro nas duas últimas décadas: o mercado externo. Boletim Agricultura. CEPEA/FEALQ n.2, p. 3-6, 1990

SHIKIDA, P. F. A. A evolução da agroindústria canavieira em Minas Gerais de 1705 a 1955. Piracicaba, 1992. 154p. Dissertação (M. S.) - Escola Superior de Agricultura "Luiz de Queiroz", Universidade de São Paulo. 
SHIKIDA, P. F. A. Política de crédito e evolução da agroindústria canavieira do Brasil durante o PROÁLCOOL. Tempo da Ciência - Revista de Ciências Sociais e Humanas, v. 1, n.2, p. 43-61, 1994.

SHIKIDA, P. F. A. Modernização da agroindústria canavieira durante o PROÁLCOOL: uma abordagem exploratória através da análise fatorial. Economia \& Empresa, v.3, n.1, p. 20-33, jan./mar. 1996.

SHIKIDA, P. F. A.; BACHA, C. J. C. A evolução da agroindústria canavieira em Minas Gerais de 1705 a 1955. Estudos Econômicos, v.24, n.1, p. 145-173, jan./abr. 1994.

SHIKIDA, P. F. A.; BACHA, C. J. C. A gênese da cultura da cana-de-açúcar em Minas Gerais. Vanguarda Econômica v.4, n.4, p. 91-101, set. 1996.

SHIKIDA, P. F. A.; GUILHOTO, J. J. M. Um panorama das indústrias do açúcar e do álcool em 1980: Minas Gerais e Brasil comparados. Revista de Economia e Sociologia Rural v.34, n. 1/2, p. 253-284, jan./jun. 1996.

SHIKIDA, P. F. A.; LOPEZ, A. A. O. Um panorama dos setores indústria do açúcar e álcool no Brasil em 1975, 1980 e 1985: estruturas comparadas. In: CONGRESSO BRASILEIRO DE ECONOMIA E SOCIOLOGIA RURAL, 35., Natal, 1997. Anais. Brasília: SOBER, 1997. p. 369-370.

SHIKIDA, P. F. A.; LOPEZ, A. A. O. A questão da mudança tecnológica e o enfoque neoclássico. Teoria e Evidência Econômica v. 5, n.9, p. 79-90, maio 1997.

SLlVA, C. R. L. Inovação tecnológica na agricultura brasileira: aspectos distributivos. São Paulo, 1992. 216p. Tese (Doutorado) - Faculdade de Economia, Administração e Contabilidade, Universidade de São Paulo.

SLVA, M. E. da Inovação tecnológica no setor de máquinas-ferramentas brasileiro: um estudo de caso. São Paulo, 1982. 129p. Dissertação (Mestrado) - Faculdade de Economia, Administração e Contabilidade, Universidade de São Paulo.

SILVA, R. F. Pernambuco. Sinopse histórica do açúcar. In: Anuário Acucareiro. Rio de Janeiro, 1935. p. 119-123.

SIMONSEN, R. C. História econômica do Brasil: 1500-1820. 6.ed. Rio de Janeiro: Nacional, 1969. 475p.

SINGER, P. Desenvolvimento econômico e evolução urbana. 2.ed. São Paulo: Nacional, 1977. 377p.

SOBRINHO, B. L. Problemas econômicos e sociais da lavoura canavieira. Rio de Janeiro: Pimenta de Mello \& Cia, 1941. 182p. 
SOCIEDADE DOS PRODUTORES DE ÁLCOOL (SOPRAL). Nove anos de Proálcool. In: SOPRAL informativo, p.23-32, dez., 1984.

SOLOW, R. M. El cambio técnico y la función de producción agregada. In: ROSENBERG, N., org. Economía del cambio tecnológico, México: Fondo de Cultura Económica, 1979. p. 319-336

SORJ, B. Estado e classes sociais na agricultura. Rio de Janeiro: Zahar, 1980. 152p.

SOTERO, A. Por uma nova política de açúcar e álcool. Agroanalysis, v.16, n.11, p. 2223, novembro 1996.

SOTO B., F. Da indústria do papel ao complexo florestal no Brasil: o caminho do corporatismo tradicional ao neocorporatismo. Texto para Discussão. UNICAMP/IE n. 14, p.1-48, jan. 1993.

STALDER, S. H. G. de M.; BURNQUIST, H. L. A importância dos subprodutos da agroindústria sucroalcooleira. Preços Agrícolas, n. 108, p. 8-9, out. 1995.

STALDER, S. H. G. de M.; BURNQUIST, H. L. A importância dos subprodutos da cana-de-açúcar no desempenho do setor agroindustrial. Revista de Economia e Sociologia Rural, v.34, n. 3/4, p.103-119, jul./dez. 1996.

STEINDL, J. Maturidade e estagnação no capitalismo americano. São Paulo: Abril Cultural, 1983. 264p. (Série "Os Economistas")

STREECK, W.; SCHMITTER, P. C. Community, market, state - and associations? The prospective contribution of interest governance to social order. In: STREECK, W.; SCHMITTER, P. C., edts. Private interest government: beyond market and state. London: Sage, 1985. p. 1-29.

SUMA ECONÔMICA, n.209, jul. 1996.

SUZIGAN, W. Indústria brasileira: origem e desenvolvimento. São Paulo: Brasiliense, 1986. $403 p$.

SZMRECSÁNYI, T. O planejamento da agroindústria canavieira do Brasil (1930-1975). São Paulo: HUCITEC/UNICAMP, 1979. 540p.

SZMRECSÁNYI, T. Concorrência e complementariedade no setor açucareiro. Cadernos de Difusão de Tecnologia v.6, n.2/3, p. 165-182, maio/dez 1989.

SZMRECSÁNYI, T. Tecnologia e degradação ambiental: o caso da agroindústria canavieira no Estado de São Paulo. Informações Econômicas, v.24, n.10, p. 7381, out. 1994.

TECNOLOGIA amplia uso dos adoçantes. Jornal do Brasil, Rio de Janeiro, 26 set. 1993. p. 5 
TESOURO paga Cr\$82,1 bilhões da dívida externa de 23 usinas. Folha de São Paulo, São Paulo, 27 mar. 1991. p.1-9

VEIGA FILHO, A. de A.; SANTOS, Z. A. P. de S.; VEIGA, J. E. R.; OTANI, M. N.; YOSHII, R. J. Análise da mecanização do corte da cana-de-açúcar no Estado de São Paulo. Informações Econômicas, v.24, n.10, p. 43-58, out. 1994.

VEIGA FILHO, A. de A.; SANTOS, Z. A. P. de S. Padrão tecnológico da cana-deaçúcar no Estado de São Paulo: evidências empíricas da evolução na cultura. Informações Econômicas, v.25, n.8, p. 15-25, ago. 1995.

VENDAS de automóveis a álcool despencam 76\%. Folha de São Paulo, São Paulo, 2 out. 1995. p.2-3.

VILLANOVA, J. A. Panorama estrutural do segmento sucroalcooleiro. Agroanalysis, v. 15, n.3, p. 8-12, mar. 1995.

VISÃO - 'Quem é Quem na economia brasileira”. São Paulo, edições especiais de 1976, 1979, 1980, 1981, 1984, 1986, 1988 e 1992.

VON LIPPMANN, E. O. História do acúcar. Rio de Janeiro: IAA, 1941. 466p.

WANDERLEY, L. A. Agroindústria açucareira do Estado do Alagoas, sua importância sócio-econômica e absorção de mão-de-obra. Salvador, 1981. 112p. Dissertação (M. S.) - Faculdade de Ciências Econômicas; Universidade Federal da Bahia.

WANDERLEY, M. de N. B. Capital e propriedade fundiária: suas articulações na economia açucareira de Pernambuco. Rio de Janeiro: Paz e Terra, 1979. 145p.

WILSON, D. C.; BUTLER, R. J. Corporation in the British voluntary sector. In: STREECK, W.; SCHMITTER, P. C., edts. Private interest government: beyond market and state, London: Sage, 1985. p. 72-86.

WORLD sugar outlook. Sugar Journal, Feb. 1994. p. 2-8.

ZAWISLAK, P. A. Uma abordagem evolucionária para a análise de casos de atividade de inovação no Brasil. Ensaios FEE, Porto Alegre, v.17, n.1, p.323-354. 1996. 
APÊNDICES 


\section{APÊNDICE A}

\section{Notas sobre o ciclo da lavoura canavieira e o seu calendário agrícola}

O ciclo da lavoura canavieira varia de três a dez anos, conforme o prazo de maturação do canavial e do número de cortes efetuados; já o ciclo vegetativo dessa lavoura tem a duração de um a dois anos, no qual podem ocorrer a "cana de ano-e-meio" ou a "cana-de-ano". O calendário agrícola da cultura canavieira no País segue as configurações fisico-ambientais do território brasileiro. As fases de produção da cana-deaçúcar se adequam de acordo com as características de duas grandes macrorregiões nacionais, Norte/Nordeste e Centro-Sul (Szmrecsányi, 1979).

Considera-se como ano-safra da cultura canavieira o período de 10 de junho a 31 de maio do ano subseqüente. Para o Norte/Nordeste o preparo do solo (que implica em aração, calagem e gradagem) compreende os meses de abril a setembro; o plantio (sulcamento, adubação e plantio) compreende os meses de junho a setembro; os tratos culturais (erradicação de ervas daninhas, aplicação de inseticidas e fungicidas, irrigação eventual - e tratos culturais das soqueiras) compreende os meses de outubro a abril; e a colheita (corte, carregamento e transporte para a unidade de processamento industrial) compreende os meses de setembro a março. Para o Centro-Sul o preparo do solo compreende os meses de setembro a fevereiro; o plantio compreende os meses de janeiro e fevereiro; os tratos culturais compreende os meses de julho a janeiro; e a colheita compreende os meses de junho a novembro [PLANALSUCAR, citado por Szmrecsányi (1979)]. 


\section{APÊNDICE B}

\section{Produtos calóricos e não-calóricos}

Os principais produtos calóricos são: frutose, glicose, xarope de milho, maltose, mel de abelha, lactose, lactitol, sorbitol, xilitol e manitol. Sobre esses produtos tem-se o seguinte ${ }^{1}$ :

- frutose, encontrado em algumas plantas e frutas, cuja representação formular é $\mathrm{C}_{6} \mathrm{H}_{12} \mathrm{O}_{6}$. Tem poder adoçante cerca de 2,2 vezes superior à sacarose e 1,5 vezes superior à glicose. É menos calórica e não provoca cáries, porém, seu custo é de 5 a 10 vezes superior ao do açúcar comum;

- glicose, encontrada em algumas plantas e frutas, cuja representação formular é também $\mathrm{C}_{6} \mathrm{H}_{12} \mathrm{O}_{6}$. $\mathrm{O}$ xarope de glicose é de digestão mais fácil e $50 \%$ mais doce;

- xarope de maltose, é o açúcar redutor obtido pela composição enzimática do amido da mandioca, batata, arroz ou milho, cuja representação formular é igual a da sacarose - $\mathrm{C}_{12} \mathrm{H}_{22} \mathrm{O}_{11}$. É usado comumente como enchimento de doces devido sua consistência pastosa;

- mel de abelha, é uma substância extremamente doce, elaborada pelas abelhas a partir da extração do néctar das flores ou de substâncias açucaradas como o caldo de cana e melaço. Apresenta alto valor energético e é de fácil assimilação pelo organismo;

- lactose, açúcar do leite, encontrado no leite dos mamíferos e em algumas flores e frutas, cuja representação formular é igual à da sacarose, $\mathrm{C}_{12} \mathrm{H}_{22} \mathrm{O}_{11}$. É usada como suporte e estabilizador de vários aromas e produtos farmacêuticos;

- lactitol, trata-se da lactose combinada com o hidrogênio, encontrada em sopas instantâneas, chocolate, bebidas e sorvetes. Pode ser usado por diabéticos;

\footnotetext{
${ }^{1}$ Este detalhamento de informações baseou-se, sobremaneira, em CONN \& STUMPF (1973) e
} TECNOLOGIA amplia uso dos adoçantes. Jornal do Brasil. Rio de Janeiro, 26 set. 1993. p.05. 
- sorbitol, poliálcool mais comum, cuja representação formular é $\mathrm{C}_{6} \mathrm{H}_{14} \mathrm{O}_{6}$. Pode ser encontrado na ameixa, cereja, maça e damasco. Tem baixo poder adoçante e não provoca cáries, sendo mais utilizado como agente de volume;

- xilitol, poliálcool encontrado em algumas plantas, cuja representação formular é $\mathrm{C}_{5} \mathrm{H}_{12} \mathrm{O}_{5}$. Tem baixo poder adoçante e não provoca cáries, sendo mais usado como agente de volume; e,

- manitol, poliálcool encontrado em algas marinhas, cuja representação formular é $\mathrm{C}_{6} \mathrm{H}_{14} \mathrm{O}_{6}$. Tem baixo poder adoçante e não provoca cáries, também sendo mais usado como agente de volume.

Quanto aos principais produtos não-calóricos, destacam-se:

- stévia, extraída de uma planta originária da Serra de Amambaí. Apesar do seu sabor residual amargo e adstringente é um adoçante nutritivo que contém poucas calorias, sendo cerca de 300 vezes mais doce que o açúcar;

- sacarina, produto químico sintetizado, cuja fórmula é $\mathrm{C}_{7} \mathrm{H}_{5} \mathrm{O}_{3} \mathrm{~N}_{5}$. É o mais antigo e o mais barato entre seus similares. Foi considerado cancerígeno e proibido nos Estados Unidos por não ser totalmente metabolizado pelo organismo. Esse produto adoça 350 vezes mais do que o açúcar;

- ciclamato, trata-se de um ester do ácido ciclâmico. É um adoçante não-nutritivo também não totalmente metabolizado pelo organismo;

- aspartame, obtido a partir da síntese da fenilanina e ácido aspártico - podendo este último ser encontrado na cana-de-açúcar e melaços da beterraba. Adoça cerca de 200 vezes mais do que o açúcar;

- acesulfame de potássio, derivado de um sal de potássio sintético, é empregado industrialmente em chicletes, bebidas e bombons. Adoça 200 vezes mais do que o açúcar e tem a vantagem de não deixar sabor residual e de não ser absorvido pelo organismo. Entretanto, é o mais caro adoçante encontrado no mercado; 
- talina, extraído de uma fruta do oeste da África. Apesar de ter um poder adoçante entre 2.000 e 5.000 vezes maior que a sacarose, deixa sabor residual amargo; e,

- anidridos de frutose, obtidos a partir do tratamento do ácido da insulina ou da frutose. É uma novidade no mercado de adoçantes. 


\section{APÊNDICE C}

\section{Q UESTIO N Á R I O}

1. Marque com um $\mathbf{X}$ o Estado onde está localizada a sua usina e/ou destilaria:

$\begin{array}{llllll}\text { ( ) } \mathrm{SP} & \text { ( ) } \mathrm{PR} & \text { ( ) } \mathrm{MG} & \text { ( ) } \mathrm{RJ} & \text { ( ) } \mathrm{AL} & \text { ( ) } \mathrm{PE}\end{array}$

2. Sua empresa é filiada a alguma cooperativa (sim ou não)?

Se sua resposta for afirmativa, a que Cooperativa pertence?

\section{QUESTÕES DE POLÍTICA SETORIAL}

Assinale com um $\mathbf{X}$ suas respostas às seguintes perguntas:

3. Como sua empresa sentiu a extinção do IAA?
( ) favoravelmente
( ) indiferente
( ) desfavoravelmente

4. Como sua empresa sentiu a extinção do PLANALSUCAR?
( ) favoravelmente
( ) indiferente
( ) desfavoravelmente

5. Como você vê o atual endividamento da agroindústria canavieira?

( ) necessário para a sobrevivência do setor

( ) necessário para o crescimento do setor

( ) indiferente

( ) não necessário, por quê?

6. Assinale com um $\mathbf{X}$, no quadro abaixo, como considera a atual política de preços da cana-de-açúcar, açúcar e álcool praticadas pelo Governo Federal para o produtor.

\begin{tabular}{|c|c|c|}
\hline Política de preços para & Adequada & Inadequada \\
\hline Cana-de-açúcar & & \\
\hline Açúcar & & \\
\hline Alcool & & \\
\hline
\end{tabular}

7. Assinale com um $\mathbf{X}$, no quadro abaixo, como considera a atual política de crédito para o produtor de cana-de-açúcar praticada pelo Governo Federal.

$$
\text { ( ) adequada ( ) inadequada }
$$




\section{QUESTÕES DE POLÍTICA TECNOLÓGICA}

Assinale com um $\mathbf{X}$ suas respostas às seguintes perguntas:

8. Há setores dentro da empresa responsáveis por P\&D (Pesquisa e Desenvolvimento)?

( ) sim, em que área?

( ) em termos (no caso da empresa ser cooperada e a Cooperativa desenvolver $\mathrm{P} \& \mathrm{D})$

( ) não

9. Como os problemas técnicos do processo produtivo são resolvidos?

( ) através dos próprios técnicos da usina/destilaria

( ) através de assistência técnica fornecida por terceiros

( ) através da Cooperativa (que possui uma área de prestação de serviços)

( ) outra forma (especificar),

10. Dê notas de 0 a 10 para os principais fatores que barram a adoção de novas tecnologias na agroindústria canavieira (obs.: maior nota significa maior obstáculo para a adoção de novas tecnologias):

\begin{tabular}{|c|c|}
\hline Fatores & Notas \\
\hline Os empresários da agroindústria canavieira preferem não assumir riscos & \\
\hline $\begin{array}{l}\text { O mercado dessa agroindústria, bastante regulamentado pelo Estado, não } \\
\text { favorece a inovação }\end{array}$ & \\
\hline $\begin{array}{l}\text { Para outros subprodutos da agroindústria canavieira (por exemplo, bagaço } \\
\text { da cana) ainda não há um mercado consolidado a ponto de incentivar o } \\
\text { surgimento de novas tecnologias }\end{array}$ & \\
\hline Excesso de oferta de cana-de-açúcar & \\
\hline Grande distância entre os centros de pesquisa e a unidade produtora & \\
\hline Outros (especificar): . & \\
\hline
\end{tabular}


11. Assinale com um $\mathrm{X}$, no quadro abaixo, as principais tecnologias agrícolas aplicadas por sua usina e/ou destilaria, durante as safras 1985/86 e 1995/96.

\begin{tabular}{|c|c|c|c|c|c|}
\hline \multirow[b]{2}{*}{ Tecnologias } & \multicolumn{5}{|c|}{ Safra $1985 / 86$} \\
\hline & $\begin{array}{l}100 \% \text { da } \\
\text { área } \\
\text { cultivada }\end{array}$ & $\begin{array}{c}70 \% \text { a } 90 \% \\
\text { da área } \\
\text { cultivada }\end{array}$ & $\begin{array}{c}40 \% \text { a } 60 \% \\
\text { da área } \\
\text { cultivada }\end{array}$ & $\begin{array}{c}\text { menos de } 40 \% \\
\text { da área } \\
\text { cultivada }\end{array}$ & $\begin{array}{c}\text { não } \\
\text { utilizada }\end{array}$ \\
\hline \multicolumn{6}{|l|}{ uso de irrigação (com água) } \\
\hline \multicolumn{6}{|l|}{$\begin{array}{l}\text { uso de irrigação (com } \\
\text { vinhaça) }\end{array}$} \\
\hline \multicolumn{6}{|l|}{ uso de defensivo } \\
\hline \multicolumn{6}{|l|}{ uso de adubação } \\
\hline \multicolumn{6}{|l|}{ uso de sementes compradas } \\
\hline \multirow[b]{2}{*}{ Tecnologias } & \multicolumn{5}{|c|}{ Safra $1995 / 96$} \\
\hline & $\begin{array}{c}100 \% \text { da } \\
\text { área } \\
\text { cultivada }\end{array}$ & $\begin{array}{c}70 \% \text { a } 90 \% \\
\text { da área } \\
\text { cultivada }\end{array}$ & $\begin{array}{c}40 \% \text { a } 60 \% \\
\text { da área } \\
\text { cultivada }\end{array}$ & $\begin{array}{c}\text { menos de } 40 \% \\
\text { da área } \\
\text { cultivada }\end{array}$ & $\begin{array}{c}\text { não } \\
\text { utilizada }\end{array}$ \\
\hline \multicolumn{6}{|l|}{ uso de irrigação (com água) } \\
\hline \multicolumn{6}{|l|}{$\begin{array}{c}\text { uso de irrigação (com } \\
\text { vinhaça) }\end{array}$} \\
\hline \multicolumn{6}{|l|}{ uso de defensivo } \\
\hline \multicolumn{6}{|l|}{ uso de adubação } \\
\hline uso de sementes compradas & & & & & \\
\hline
\end{tabular}

12. Assinale com um $X$, no quadro abaixo, a utilização de máquinas $e$ implementos agrícolas (própria ou de terceiro) utilizadas por sua usina e/ou destilaria, durante as safras 1985/86 e 1995/96.

\begin{tabular}{|c|c|c|c|c|c|c|}
\hline \multirow{3}{*}{ Itens } & \multicolumn{3}{|c|}{ Safra $1985 / 86$} & \multicolumn{3}{|c|}{ Safra 1995/96 } \\
\hline & \multicolumn{2}{|c|}{ Usou } & \multirow{2}{*}{$\begin{array}{l}\text { Não } \\
\text { usou }\end{array}$} & \multicolumn{2}{|c|}{ Usou } & \multirow{2}{*}{$\begin{array}{l}\text { Não } \\
\text { usou }\end{array}$} \\
\hline & Própria & Terceiro & & Própria & Terceiro & \\
\hline \multicolumn{7}{|l|}{ Máquinas para o plantio } \\
\hline \multicolumn{7}{|l|}{ Máquinas para a colheita } \\
\hline \multicolumn{7}{|l|}{ Arado mecânico } \\
\hline Uso de caminhões (transporte da cana) & & & & & & \\
\hline
\end{tabular}

\section{QUESTÕES DE ÂMBITO DA PRODUÇÃO}

13. Preencha no quadro abaixo, para as safras 1985/86 e 1995/96, as percentagens da cana-de-açúcar que advêm de fornecedor e quanto é cana própria (a soma em cada coluna dá $100 \%$ )

\begin{tabular}{|c|c|c|}
\hline Tipo & $1985 / 86$ & $1995 / 96$ \\
\hline Cana de fornecedor & $\%$ & $\%$ \\
\hline Cana própria & $\%$ & $\%$ \\
\hline
\end{tabular}


14. Responda, no quadro abaixo, sua capacidade máxima de produção e sua produção efetiva nas safras $1985 / 86$ e 1995/96?

\begin{tabular}{|c|c|c|}
\hline & S A F R A 1985/86 \\
\hline Produtos & Capacidade de produção & Produção efetiva \\
\hline açúcar & & \\
\hline álcool & & \\
\hline & S A F R A 1995/96 & \\
\hline Produtos & Capacidade de produção & Produção efetiva \\
\hline açúcar & & \\
\hline álcool & & \\
\hline
\end{tabular}

15. Assinale com um $\mathbf{X}$, no quadro abaixo, como foram aproveitados os subprodutos derivados da cana-de-açúcar, para as safras 1985/86 e 1995/96.

\begin{tabular}{|c|c|c|c|c|c|}
\hline \multirow[b]{3}{*}{ Subprodutos } & \multicolumn{5}{|c|}{ Safra $1985 / 86$} \\
\hline & \multicolumn{5}{|c|}{ Aproveitamento } \\
\hline & Venda & $\begin{array}{c}\text { Usado } \\
\text { intensivamente } \\
\text { na produção }\end{array}$ & $\begin{array}{l}\text { Usado } \\
\text { parcialmente } \\
\text { na produção }\end{array}$ & $\begin{array}{c}\text { Em fase de } \\
\text { pesquisas para } \\
\text { possível } \\
\text { aproveitamento }\end{array}$ & Descartado \\
\hline \multicolumn{6}{|l|}{ bagaço } \\
\hline \multicolumn{6}{|l|}{ vinhoto } \\
\hline \multicolumn{6}{|l|}{ óleo fusel } \\
\hline \multicolumn{6}{|l|}{ gás carbônico } \\
\hline \multicolumn{6}{|l|}{ leveduras } \\
\hline \multicolumn{6}{|l|}{ torta de filtro } \\
\hline \multicolumn{6}{|l|}{$\begin{array}{c}\text { outros } \\
(\ldots \ldots \ldots \ldots \ldots) \\
\end{array}$} \\
\hline \multicolumn{6}{|c|}{ Safra $1995 / 96$} \\
\hline \multirow[b]{2}{*}{ Subprodutos } & \multicolumn{5}{|c|}{ Aproveitamento } \\
\hline & Venda & $\begin{array}{c}\text { Usado } \\
\text { intensivamente } \\
\text { na produção }\end{array}$ & $\begin{array}{l}\text { Usado } \\
\text { parcialmente } \\
\text { na produção }\end{array}$ & $\begin{array}{c}\text { Em fase de } \\
\text { pesquisas para } \\
\text { possivel } \\
\text { aproveitamento }\end{array}$ & Descartado \\
\hline \multicolumn{6}{|l|}{ bagaço } \\
\hline \multicolumn{6}{|l|}{ vinhoto } \\
\hline \multicolumn{6}{|l|}{ óleo fusel } \\
\hline \multicolumn{6}{|l|}{ gás carbônico } \\
\hline \multicolumn{6}{|l|}{ leveduras } \\
\hline \multicolumn{6}{|l|}{ torta de filtro } \\
\hline $\begin{array}{c}\text { outros } \\
(\ldots \ldots \ldots \ldots \ldots)\end{array}$ & & & & & \\
\hline
\end{tabular}

